\title{
Indian warfare, household competency, and the settlement of the western Virginia frontier, 1749 to 1794
}

John M. Boback

West Virginia University

Follow this and additional works at: https://researchrepository.wvu.edu/etd

\section{Recommended Citation}

Boback, John M., "Indian warfare, household competency, and the settlement of the western Virginia frontier, 1749 to 1794" (2007). Graduate Theses, Dissertations, and Problem Reports. 2566.

https://researchrepository.wvu.edu/etd/2566

This Dissertation is protected by copyright and/or related rights. It has been brought to you by the The Research Repository @ WVU with permission from the rights-holder(s). You are free to use this Dissertation in any way that is permitted by the copyright and related rights legislation that applies to your use. For other uses you must obtain permission from the rights-holder(s) directly, unless additional rights are indicated by a Creative Commons license in the record and/ or on the work itself. This Dissertation has been accepted for inclusion in WVU Graduate Theses, Dissertations, and Problem Reports collection by an authorized administrator of The Research Repository @ WVU.

For more information, please contact researchrepository@mail.wvu.edu. 


\title{
Indian Warfare, Household Competency, and the Settlement of the Western Virginia Frontier, 1749 to 1794
}

John M. Boback

Dissertation submitted to the College of Arts and Sciences at West Virginia University in partial fulfillment of the requirements for the degree of

\author{
Doctor of Philosophy \\ in \\ History
}

\author{
Ronald L. Lewis, Ph.D., Chair \\ Tyler Boulware, Ph.D. \\ James Daddysman, Ph.D. \\ Ken Fones-Wolf, Ph.D. \\ Barbara Rasmussen, Ph.D
}

\section{Department of History}

\author{
Morgantown, West Virginia \\ 2007
}

Keywords: Frontier, Warfare, Violence, Shawnee, Economy, Subsistence, Commercialism, Competency, West Virginia 


\section{Abstract \\ Indian Warfare, Household Competency, and the Settlement of the Western Virginia Frontier, 1749 to 1794}

\section{John M. Boback}

The thesis of this dissertation is that Indian-related violence and warfare had a profound influence on the duration and nature of the frontier experience of those men and women who settled in the western Virginia backcountry between 1749 and 1794. Recurrent attacks by Shawnees, Delawares, Mingos, and Indians from the Great Lakes region caused such widespread death, destruction, and depopulation that it effectively prolonged the period of austere and difficult living conditions for over forty years. This conclusion contradicts the assertions of some recent scholars who have argued that crude living conditions lasted for only a year or two on the Appalachian frontier, and that economic conditions improved rapidly. While this may have been the case in some sub-regions of Appalachia that experienced minimal upheaval from Indian attacks, this was not the case in trans-Allegheny "West Virginia." The negative influence of Indian-associated violence manifested itself not only in how long it took Euro-Americans to gain hegemony over the region, but also in the household economies of the individual families. By using "competency" as a model for understanding household economics, it is demonstrated that although many settlers embraced the commercial economy when possible, the rigors of life on the oftentimes-violent frontier frequently left them no option but to shift their focus of their household production away from commercial production in favor of subsistence activities. 


\section{Acknowledgments}

As I look upon this completed dissertation, I am amazed by how fully it incorporates and embodies the many ideas and arguments that I was exposed to over the years as a graduate student at West Virginia University. Otherwise disparate class readings, seminar papers, book reviews, reflective essays, formal class discussions, and informal conversations in hallways and offices somehow congealed into a coherent research project and dissertation. Any success that I have had as a student is a reflection of the quality of the professors that I have had the good fortune of working with over the years. In particular, I would like to thank Ron Lewis and Mary Lou Lustig who both served as my advisors as I pursued my masters and doctoral degrees. I consider it an honor to have studied under them.

I would also like to offer my deepest gratitude to Ken Fones-Wolf, Barbara Rasmussen, and Tyler Boulware for their willingness to serve as readers on my committee. Their time, generosity, and gentle criticisms are truly appreciated. A heartfelt thanks is also extended to Lynn Laufenberg who exemplified what a classroom instructor should be. I found her excitement for teaching to be contagious.

Lastly, I would like to offer a special word of thanks to my undergraduate advisor and friend Jim Daddysman. Not only was he there for me when I first walked into his office as a freshman history major at Alderson-Broaddus College, but he was also present as a member of my dissertation committee twenty-two years later when I completed my doctoral studies. I think of him as "bookends" on my college career. To Jim I dedicate this dissertation. 


\section{Table of Contents}

$\begin{array}{ll}\text { ii } & \text { Abstract } \\ \text { iii } & \text { Acknowledgments } \\ \text { iv } & \text { Table of Contents } \\ v & \text { List of Tables } \\ v i & \text { List of Maps } \\ v i i & \text { Abbreviations } \\ 1 & \text { Chapter 1: Introduction } \\ 19 & \text { Chapter 2: Conceptualizing the Western Virginia Frontier } \\ 41 & \text { Chapter 3: Shawnee Culture and the Ceremonialism of Violence } \\ 180 & \text { Chapter 4: Settling the Western Virginia Backcountry } \\ 65 & \text { Chapter 5: Producing for the Household and Market } \\ 102 & \text { Chapter 6: Conflict and Competency } \\ 150 & \end{array}$




\section{List of Tables}

140 Table 1: Household Size in Monongalia County, 1782

141 Table 2: Cattle Herds in Select Western Virginia Counties, 1787

143 Table 3: Slave Ownership in Select Western Virginia Counties, 1787

144 Table 4: Settlers Assessed for Twenty or More Cattle, 1787

163 Table 5: Documented New Settlers in Monongalia County 


\section{List of Maps}

(located after appendices)

Map 1: Physical Geography of western Virginia Frontier

Map 2: Migration Routes of Settlers

Map 3: Refuge Forts Built on the Western Virginia Frontier, 1754-1772

Map 4: Refuge Forts Built on the Western Virginia Frontier, 1773-1774

Map 5: Refuge Forts Built on the Western Virginia Frontier, 1775-1794 


\section{Abbreviations}

Bouquet Papers Stevens, Sylvester K. and Donald H. Kent, eds. The Papers of Col. Henry Bouquet, series 21650, pt. 2. Harrisburg: Pennsylvania Historic Commission, 1943.

Diary GW Fitzpatrick, John C., ed. The Diaries of George Washington, 1748-1799.

Vol. 1. Boston: Houghton Mifflin, 1925.

Writings GW Fitzpatrick, John C., ed. The Writings of George Washington from the

Original Manuscript Sources. Washington, D. C.: Government Printing Office, 1931.

Doc. Dunmore's War Thwaites, Reuben G. and Louise P. Kellogg, eds. Documentary History of Dunmore's War, 1774. Madison: Wisconsin Historical Society, 1905.

Doc. His. N.Y. O'Callaghan, E. B., ed., Documents Relative to the Colonial History of the State of New York. Albany: Weed, Parsons, 1853-1887.

HSW Historical Society of Wisconsin

JR Thwaites, Reuben G., ed. The Jesuit Relations and Allied Documents. Vol. 59. Cleveland: Burrows Brothers Company, 1900.

Penn. Archives Hazard, Samuel, ed., Pennsylvania Archives, Philadelphia: Joseph Severns, 1853.

PFMFA Pricketts Fort Memorial Foundation Archives, Fairmont, West Virginia WVRHC West Virginia and regional History Collection, West Virginia University, Morgantown, West Virginia 


\section{Chapter One}

\section{Introduction}

Americans have long been fascinated by the pioneer image. Rugged, brave, larger than life, the pioneers of popular imagination left friends and family behind as they ventured westward in search of adventure and what they hoped would be better lives. On the frontier, these archetypal Americans faced hostile Indians, wild animals, and a host of other tribulations as they carved homes from what Daniel Boone described as the "howling wilderness." Over the years, much has been written on the lives, history, and experiences of the pioneers who settled the Appalachian Mountain region. Unfortunately, writers disagree over how their frontier experience should be characterized. Two primary schools of thought prevail. First, there is a more traditional view that envisions Appalachian people as having experienced the frontier as a protracted period of austere living conditions that lasted into the twentieth century. According to this model, the alleged physical and cultural isolation of the settlers caused the frontier period of their history to stagnate for well over a hundred years. The second much more recent interpretation takes the opposite perspective by presenting the frontier period of Appalachian history as being quite ephemeral. While recognizing that the rugged geography of the region posed series challenges to transportation, communication, and commerce, proponents of this position argue that difficult frontier living conditions in Appalachia lasted but a year or two following initial settlement. ${ }^{2}$

${ }^{1}$ John Filson, The Discovery, Settlement, and Present State of Kentucke (1784; reprint, Ann Arbor: University Microfilms, 1966), 49.

${ }^{2}$ Robert D. Mitchell, Commercialism and Frontier: Perspectives on the Early 
Although both models of the Appalachian frontier experience raise important issues, such as the question of physical isolation, the difficulties of transportation, and the nature of regional economic development, a common shortcoming is that they both fail to adequately account for Indian resistance to white settlement. The thesis of this dissertation is that Indian attacks into western Virginia during the second half of the eighteenth century caused such widespread damage, destruction, depopulation, and death that it effectively prolonged the frontier period of "West Virginia" history for forty years. From the mid-1750s through the mid-1790s, Indianrelated violence and warfare hindered the development of western Virginia. This in turn caused it to lag behind other Appalachian frontiers where Indian-related violence may not have presented such a serious impediment to European occupation. In the course of exploring the relationship between Indian warfare and the European settlement of western Virginia, several important secondary issues are also discussed including the nature of the pioneer household economy, the myth of pioneer self-sufficiency, and the critical question of how the "West Virginia" frontier should even be conceptualized.

The geographic focus of this study is that portion of West Virginia situated west of the Allegheny Mountains. The Allegheny Mountains consist of a series of high roughly parallel ridges oriented generally in a northeast to southwest direction. With many individual peaks exceeding three thousand feet in elevation and few natural passes, the mountains hindered travel and communication between eastern and western Virginia. Immediately west of the Allegheny

Shenandoah Valley (Charlottesville: University Press of Virginia, 1977), 3; Paul Salstrom, Appalachia's Path to Dependency: Rethinking a Region's Economic History, 1730-1940 (Lexington: University Press of Kentucky, 1994), 5; Wilma A. Dunaway, The First American Frontier: Transition to Capitalism in Southern Appalachia, 1700-1860 (Chapel Hill: University of North Carolina Press, 1996), 10. 
Mountains is the Allegheny Plateau, a region characterized by hills, narrow valleys, and many creeks and rivers. All of the watercourses west of the Allegheny Mountains eventually empty into the southwest-flowing Ohio River. The region has a temperate climate with an average growing season of 153 days. Precipitation totals range from forty-two inches per year along the Ohio River up to sixty-six inches annually in the high Allegheny Mountains. The abundant rainfall, temperate climate, and fertile soil contributed to the growth of a dense predominately deciduous forest in the lower elevations with extensive tracts of spruce and hemlock in the mountains. ${ }^{3}$

For the sake of clarity, several geographic terms must be explained. In the eighteenth century, the present state of West Virginia did not exist. Initially part of the Virginia Colony and later the state of Virginia, it was not until June 1863 that West Virginia became a state in its own right following its separation from Virginia in the midst of the Civil War. In the following chapters, "western Virginia" typically means that portion of Virginia that lay west of the Allegheny Front, the easternmost ridge of the Allegheny Mountains. Likewise, "trans-Allegheny Virginia" also refers to that portion of Virginia situated west of the Allegheny Front. On the other hand, "Appalachian Virginia" includes not only the trans-Allegheny region, but also the Blue Ridge and Valley of Virginia. And in the eighteenth century, all of Virginia from the Blue Ridge west could be considered the backcountry, or back counties. Although many of these terms are similar, they are not necessarily synonymous. (See Map 1)

One of the points made in this study is that although western Virginia may have been remote from eastern cities such as Williamsburg and Philadelphia, the region did not exist in isolation. Thus, at times it is necessary to go beyond the bounds of trans-Allegheny Virginia

\footnotetext{
${ }^{3}$ Earl L. Core, Vegetation of West Virginia (Parsons, W. Va.: McClain, 1966), 1-7, 41-45.
} 
when examining matters such as colonial and imperial land policies, the economic background of the settlers, and the Shawnee Indians who had largely been pushed out of western Virginia into present Ohio by the mid-1760s. At other times, documentary sources from present southwestern Pennsylvania and eastern Kentucky are used to buttress or illuminate a particular point. Although technically not within the bounds of present West Virginia, both regions fell under the jurisdiction of Virginia throughout much of the second half of the eighteenth century. In fact, the current state of Kentucky used to be Kentucky County, Virginia. But even more importantly, settlers in western Virginia, southwestern Pennsylvania, and eastern Kentucky lived a very similar lifestyle throughout the Revolutionary era.

The impetus for this study emerged from two different sources. The first of these originated in the summer of 1993 when I became employed as a costumed historical interpreter at Prickett's Fort State Park, the site of a reconstructed 1770s era frontier fort. ${ }^{4}$ As a park historian, not only did I talk with the general public on a daily basis about the settlers, Indians, forts, and frontier warfare, but I also dressed as a frontiersman and demonstrated many of the tasks associated with daily frontier life. Some of these activities included scraping deer hides, handsewing historically accurate clothing, working in the gardens, splitting and hauling firewood, starting fires with flint and steel, throwing a tomahawk, and using walnut hulls and other local plants to dye clothing. In addition, I also often worked as a "frontier artisan" at the fort blacksmith shop. Over time, I began to realize that a connection existed between Indian warfare,

\footnotetext{
${ }^{4}$ Prickett's Fort State Park located near Fairmont, West Virginia is the site of a reconstructed 1770s era refuge fort and a restored Civil War era brick farmhouse. The fort is staffed by costumed historic interpreters who educate the public about the Indians of West Virginia, backcountry culture, and a variety of historic trades such as spinning, weaving, hearth cooking, blacksmithing, and historic gardening.
} 
the domestic economy of the settlers, and the duration of frontier living conditions. My experiences and research at Prickett's Fort State Park are the foundation of this present study.

The second major impetus for this study emerged while conducting research for my master's thesis on the household economy in western Virginia during the 1770 s and 1780 s. In the course of my readings, it became evident that disagreement existed over how the Appalachian frontier experience should be characterized. I found it interesting how some revisionist scholars writing in the 1970s and using quantitative methodologies had challenged the traditional notion that Appalachian people had experienced the frontier as a protracted period of crude living conditions. In his well-received study of the Shenandoah Valley of Virginia, historical geographer Robert Mitchell concluded that frontiers seldom reduced settlers "to a raw state of economic evolution distinguished by geographical isolation, complete self-sufficiency, and marginal living standards." He went on to explain that such crude living conditions tended to be "a temporary feature of the first year or two of initial permanent settlement.",

Mitchell's correct observation for the Shenandoah Valley portion of Appalachia subsequently influenced the paradigms of other scholars seeking to explain Appalachian history. Economic historian Paul Salstrom, for example, claimed to have found a similar pattern in West Virginia where he argued that the earliest settlers derived a very easy subsistence from their farms and the surrounding forest. ${ }^{6}$ Like Mitchell, Salstrom envisioned the Appalachian frontier experience as having been quite brief in duration. Historical sociologist Wilma Dunaway pushed Mitchell's observation even further when she generalized his "brief frontier" paradigm to include

\footnotetext{
${ }^{5}$ Mitchell, Commercialism and Frontier, 3.

${ }^{6}$ Salstrom, Appalachia's Path to Dependency, 5.
} 
all of southern Appalachia. ${ }^{7}$ Unfortunately, herein lies a problem. In making such a sweeping generalization, Dunaway failed to adequately emphasize that various sub-regions within Appalachia may have had very different developmental experiences.

The western Virginia frontier from the early 1750 s until 1794 is a case in point. Unlike some Appalachian frontiers that had a negligible level of Indian-related violence, such as the Shenandoah Valley area studied by Mitchell, settlers in western Virginia endured a protracted period of outright warfare, small scale skirmishing, and opportunistic raiding. Although sometimes referred to collectively as the West Virginia "Indian Wars," the term is somewhat of a misnomer. Warfare typically involves "open and declared armed hostile conflict between states or nations." The problem with characterizing the conflict in western Virginia as a war is that much of the fighting did not occur between nations. In many cases, small parties of fighters or individual warriors attacked one another without the formal sanction of their respective governments. Around 1772, for example, frontiersmen murdered the friendly Indian chief Bald Eagle, propped his body in a canoe, shoved a piece of johnnie cake in his mouth, and sent him afloat down the Monongahela River. ${ }^{9}$ Likewise, Shawnee warriors attacked settlers for any number of reasons including the desire for vengeance, captives, booty, horses, or recognition as a warrior.

In addition to the small-scale harassment, skirmishing, and raiding, the period running

\footnotetext{
${ }^{7}$ Dunaway, First American Frontier, 10.

${ }^{8}$ Webster's Ninth New Collegiate Dictionary, s.v. "War."

${ }^{9}$ Anthony F. C. Wallace, Jefferson and the Indians: The Tragic Fate of the First Americans (Cambridge, Mass.: Harvard University Press, 1999), 193.
} 
from 1754 through 1794 also encompassed several large scale declared conflicts that do deserve the moniker of "war." These included the French and Indian War, Pontiac's Uprising, Dunmore's War, and the Revolutionary War. Actual warfare between the Ohio Valley Indians and Virginians commenced in 1754 with the outbreak of the French and Indian War and continued in the western Virginia theater until 1760. Following that war, settlers in western Virginia enjoyed a few years of relative peace before the Ottawa chief Pontiac took up the struggle against European domination in his failed nativistic-inspired uprising that lasted from 1763 through 1765 . In the aftermath of Pontiac's defeat, a tenuous peace fell across the frontier only to be broken in 1773 as individual Indians and frontiersmen began harassing one another in scattered encounters throughout the forests and along the Ohio River. By the spring of 1774, the escalating violence had erupted into Dunmore's War that pitted the colony of Virginia against the Shawnee Indians. The victory of Virginia's forces at the Battle of Point Pleasant in October 1774 once again compelled the Indians to grudgingly accept the European's terms of peace. Less than a year later, shots rang out at Lexington and Concord creating a situation where the British and many of the Ohio Indians formed a loose alliance in their struggle against a common American enemy. Even after the Revolutionary War ended in 1781, many individual Shawnees continued to attack American settlers. Although the motivation for these scattered attacks ran the gamut from blood vengeance to common thievery to a persistent desire to rid the land of white intruders, they collectively served to prolong the period of difficult frontier living conditions. Not until 1794 following the demoralizing defeat of the Indians at the Battle of Fallen Timbers near present Toledo, Ohio did the "Indian threat" abate and the frontier period of West Virginia history come 
to a close. Throughout this extended period of violence, hundreds of pioneer families fought, struggled, lived, and died while attempting to settle within the forested hills of western Virginia. From their collective perspective, the frontier experience can hardly be characterized as having lasted but a "year or two."

As we reassess our perception of the nature and duration of the Appalachian frontier experience, it is vitally important that we not become ensnared by the old romanticized imagery that presented Appalachia as a persistent frontier lasting well into the twentieth century. In order to avoid this pitfall, it would be beneficial to carefully review the origins and development of the mythology surrounding the image of Appalachia as a "contemporary frontier." Contrary to popular belief, Appalachia does not exist as a distinct cultural region of the United States. Shortly after the Civil War, local color authors in need of an exciting backdrop for their novels and short stories "created" Appalachia in the minds of their readers through the use of characters with exaggerated personality traits and a physical landscape foreign to urban middle class readers. A central element in their writings is the notion that the rugged mountains physically isolated its inhabitants from the "outside world." Allegedly, this isolation was so complete that it left the people of Appalachia frozen in time, thus preserving eighteenth-century American frontier life. Few people seem to have questioned the validity of these characterizations, and over time, this mythical image became widely accepted as fact. ${ }^{10}$ Let us explore the development of this perception in greater depth.

It is significant that during the 1850 s, no writers characterized Appalachia as a

\footnotetext{
${ }^{10}$ Ronald L. Lewis, Transforming the Appalachian Countryside: Railroads, Deforestation, and Social Change in West Virginia, 1880-1920 (Chapel Hill: University of North Carolina Press, 1998), 1.
} 
contemporary frontier inhabited by pioneers. Americans largely understood that the frontier phase of Appalachian life had come and gone during the eighteenth and early nineteenth centuries. In order to visit the frontier on the eve of the Civil War, one had to go out West to the cattle country of Texas, or across the Oregon Trail, or to the distant gold fields of Colorado and Nevada. ${ }^{11}$

Immediately following the Civil War, perceptions of Appalachia began to change as fiction writers of the local color genre began using the mountains as an exciting setting for their short stories and travel sketches. Immensely popular among the emerging urban middle class, magazines such as Harper's and Lippincott's featured dozens of stories that presented Appalachia as a quaint, if not somewhat peculiar, place where people still lived much as they had during the days of the pioneers. ${ }^{12}$ Some writers even went so far as to imply that visiting the Appalachian Mountains permitted travelers to step backwards in time and glimpse what life had been like on England's eighteenth century colonial frontier. As one author put it, when you journey to the mountains "you detach yourself from all that you have experienced, and take up the history of English speaking men and women at the point it had reached a hundred or a hundred and fifty years ago. ${ }^{\prime 13}$ In essence, a relatively small group of late nineteenth century fiction writers fabricated the mental image of Appalachia as a place where the frontier still existed even after a

${ }^{11}$ Allen W. Batteau, The Invention of Appalachia, (Tucson: University of Arizona Press, 1990), 28, 32 .

${ }^{12}$ Will Wallace Harney, “A Strange Land and a Peculiar People," Lippincott's Magazine 12 (October 1873): 429-38.

${ }^{13}$ James Lane Allen, “Through Cumberland Gap on Horseback," Harper's Magazine, 73 (June 1886): 50-66. 
hundred years of settlement.

By the outbreak of World War I, the literary notion of Appalachia as a protracted frontier had gained widespread credence not only among patrons of the local color genre, but also among the general public. What was it about the idea that Americans found so appealing, or perhaps useful? Students of the topic have advanced several theories over the past few decades. Historian Darlene Wilson, for example, illuminates the close connection between local color author John Fox, Jr., and certain absentee mineral developers during the early twentieth century. After carefully researching family papers, she interpreted Fox's literary portrayals of Appalachia as a deliberate attempt to belittle and marginalize the local people in order to facilitate absentee corporations gaining control of the region's natural resources. ${ }^{14}$

Anthropologist Allen Batteau, on the other hand, identified another source for that appeal in the societal stresses induced by the social, political, and economic changes of the Victorian Era. During the decades immediately after the Civil War, Americans faced numerous uncertainties including industrialization, mechanization, urbanization, the internal movement of freed slaves toward the north, and the large scale immigration of Catholic workers from southern and eastern Europe. Alarmist, if not outright racist, individuals argued that even the mere physical proximity of these new immigrants could trigger the moral and genetic decline of the Protestant AngloSaxon race. As evidence of this impending decline, Henry Cabot Lodge cited disturbing trends in America such as the increasing divorce rate, declining birth rate, and the breakdown of the

${ }^{14}$ Darlene Wilson, "The Felicitous Convergence of Mythmaking and Capital Accumulation: John Fox Jr. and the Formation of An(Other) Almost-White American Underclass," Journal of Appalachian Studies 1 (Fall 1995): 6-8. 
family. ${ }^{15}$ In hopes of mitigating this perceived crisis, Americans embraced a number of coping mechanisms including Jim Crow, Americanization programs, and anti-immigration legislation. Americans also sought psychological refuge by embracing the concept of a romanticized agrarian past. In this regard, the reading of an Appalachian local color story transcended mere entertainment value by providing comfort to a distressed public by connecting them with their pioneer heritage. $^{16}$

For some Americans, reconnecting with their Anglo-Saxon pioneer past went far beyond reading a John Fox, Jr., story in the comfort of their own home. On the contrary, avid outdoorsmen such as Horace Kephart touted the many benefits of personally visiting the rugged Appalachian Mountains, where people "still live in the eighteenth century." Not only did he advocate hunting, camping, and mingling with the locals as a way for men to regain lost vigor, but he also saw it as a means of becoming better acquainted with one's pioneer roots. ${ }^{17}$ Others, including missionaries and educators, looked for ways to preserve the allegedly pure Anglo-Saxon pioneer culture of Appalachia through the creation of craft guilds and mountain schools. ${ }^{18}$

Even the highly educated credited the rugged Appalachian landscape with preserving a vestige of pure Anglo-Saxonism by isolating it from the outside world. Berea College President

${ }^{15}$ See, Henry Cabot Lodge, Short History of the English Colonies in America (New York: Harper and Brothers, 1881).

${ }^{16}$ Batteau, Invention of Appalachia, 57-62.

${ }^{17}$ Horace Kephart, Our Southern Highlanders (New York: Outing Publishing Company, 1913), 18, 29-30, 33.

${ }^{18}$ John C. Campbell, The Southern Highlander and His Homestead (Lexington: University Press of Kentucky), 2004. 
William Goodell Frost is a case in point. In an 1899 article, he described Appalachian people and their culture as a remnant of "pioneer life." The "remoteness" of the mountains had trapped these "eighteenth century neighbors" in the "log-cabin stage of life." ${ }^{\prime 19}$ Frost's highly influential article lent academic support to the developing notion of Appalachia as a land where time stood still. As the concept of Appalachia as a contemporary frontier became fixed in the minds of many Americans, a sense of ambiguity and ambivalence developed. On the negative side, frontier life evoked thoughts of crudeness, poverty, illiteracy, drunkenness, lawlessness, and violence. Idyllic Victorian propriety simply did not exist within this version of the alleged pioneer society of contemporary Appalachia. But even negative imagery attracted the interest of the general American public. While a psychoanalytical interpretation might attribute this fascination with all that is base to the yearnings of the id, modern day English professor Jerry Williamson asserts that our attraction has more to do with our desire to know ourselves. He explains that the many different manifestations of the hillbilly caricature function as a mirror reflecting the various possibilities that lie within us. On the one hand, when the object in the mirror resembles an archetypal American such as Daniel Boone or Hawkeye from Last of the Mohicans, our manliness is affirmed. But on the other hand, the savage mountain men from Deliverance evoke a sense of revulsion, yet we must look because they too reflect an "undeniable possibility in American manhood."20

\footnotetext{
${ }^{19}$ William Goodell Frost, "Our Contemporary Ancestors in the Southern Mountains," Atlantic Monthly 83 (March 1899): 311-19.

${ }^{20}$ Possibilities in American womanhood, as reflected by the female hillbilly "mirror," might include women as fighters, women as victims, and women as sexual creatures. See J. W. Williamson, Hillbillyland (Chapel Hill: University of North Carolina Press, 1995), 2, 14, 225-26.
} 
Whether one attributes national acceptance of the persistent Appalachian frontier mythology to capitalist manipulation, the need for psychological salve during stressful times, academic endorsement, a subconscious desire for all that is pleasurable, the attraction we have for ourselves, or a combination of all of the above, by the 1920s, the myth had become "fact" within the collective American conscience. As evidence that the concept of Appalachia had changed some time around the turn of the twentieth century, consider the Great Seal for the state of West Virginia. Adopted in 1863 with the motto "Montani Semper Liberi," "Mountaineers Are Always Free," the seal depicts two mountaineer archetypes, a farmer and a miner. Artist Joseph H. Diss Debar explained that his mountaineers represented the two major aspects of the state's economy: agriculture and industry. The farmer's right hand rests upon a plow with a sheaf of grain and a cornstalk positioned near his feet. His left arm cradles an axe that according to Debar represents the extensive forests that had not yet been cleared for cultivation. Even though the farmer wears the caped hunting frock of a late eighteenth century hunter, the artist does not conceptualize him as a frontiersman. He is a farmer. By 1927 , however, the concept of the mountaineer had changed as evidenced by the type of mountaineer formally adopted by West Virginia University as the school mascot. ${ }^{21}$ In the university's version, frontier implements of warfare such as the flintlock rifle and belt knife have replaced all of Debar's symbolic representations of agriculture. In short, at some point between 1863 and 1927, the mountaineer image had been transformed from farmer to frontiersman. By the same token, in 1925 when Mary Breckinridge selected a

\footnotetext{
${ }^{21}$ Sonja L. Wilson, Mountaineer Week History, $<$ http://www.sa.wvu.edu/mountainlair/history.shtml $>$ (13 January 2005). For an early photograph of the mountaineer mascot being represented as a frontiersman, see page two-hundred of the 1929 edition of The Monticola, the yearbook for West Virginia University.
} 
name for her rural Kentucky health care organization, it seemed entirely appropriate to name it the Frontier Nursing Service. ${ }^{22}$ In both cases, the mountaineer mascot and the organization name selected by Breckinridge indicate that a fundamental shift had occurred in how Americans conceptualized Appalachia.

With the general American acceptance of Appalachia as a culturally stagnant frontier, scholars from a variety of academic disciplines attempted to explain how such a situation could have arisen. Once again taking their cue from the local color literary genre, writers almost universally cited physical isolation as the primary reason for the persistence of frontier circumstances. $^{23}$ The alleged ability of geographic conditions, such as isolation, to determine human culture is no longer considered valid, however, at the turn of the twentieth century, the idea enjoyed widespread acceptance. ${ }^{24}$ One of environmental determinism's most notable proponents was geographer Ellen Churchill Semple. Writing in 1903, she explained how mile after mile of mountain ranges and rugged plateaus separated the first Appalachian settlers from

${ }^{22}$ See, Mary Breckinridge, Wide Neighborhood: Story of the Frontier Nursing Service (Lexington: University Press of Kentucky), 1981.

${ }^{23}$ In his highly popular 1907 book The Trail of the Lonesome Pine, John Fox, Jr., eloquently expressed this isolation motif. A character in the story explained "You see, mountains isolate people and the effect of isolation on human life is to crystalize it. . . They have been cut off from all communication with the outside world. They are a perfect example of an arrested civilization and they are the closest link we have with the Old World. . . They live like the pioneers, the axe and the rifle are still their weapons and they still have the same fight with nature." John Fox, Jr., The Trail of the Lonesome Pine (New York: Charles Scribner's Sons, 1908), 97.

${ }^{24}$ Today, most geographers subscribe to the idea of "possibilism" rather than determinism when describing the relationship between humanity and his environment. Based on the classic philosophical argument regarding free choice of the will, possibilists emphasize that the physical environment provides people with a set of opportunities from which they consciously make decisions according to their cultural needs. 
the "seats of civilization" in the east. Cut off from mainstream Americans and each other, wilderness "conditions modify the man along with his methods," and over time, "isolation set its stamp. ${ }^{, 25}$ As support for this contention, she cited numerous specific examples of how mountain "people are still living the frontier life of the backwoods, where the civilization is that of the eighteenth century." According to Semple, Appalachian people spoke Elizabethan English, traveled only by foot or on horseback, tended to be clannish, feuded with one another, drank an inordinate amount of moonshine whiskey, usually lived in windowless one-room log cabins, and rarely made any effort to beautify their homes. ${ }^{26}$ Although her observations are not entirely accurate, Semple helped to set the stage for later twentieth century writers who would make a more systematic effort to codify and explain the perceived defining traits of contemporary Appalachian frontier culture.

Unfortunately, the very act of distilling a particular cultural group into a list of defining traits is a perilous undertaking that places the compiler at risk of being labeled a racist or elitist. The problem is that observers have no choice but to define others in terms of what they themselves deem to be unusual or distinctive. By using such subjective methodology, there is a tendency to create a perception of local culture that is oppositional to the culture of the observer. ${ }^{27}$ Consider Presbyterian minister Jack Weller who lived and worked with the people of

${ }^{25}$ Ellen Churchill Semple, American History and Its Geographic Conditions (Boston: Houghton, Mifflin and Company, 1903), 78-79.

${ }^{26}$ Ellen Churchill Semple, "The Anglo-Saxons of the Kentucky Mountains: A Study in Anthropogeography," The Geographical Journal 17 (June 1901): 588, 590, 596, 598, 609.

${ }^{27}$ Allen Batteau, "Appalachia and the Concept of Culture: A Theory of Shared Misunderstandings," Appalachian Journal 7 (Autumn-Winter, 1979-80): 11. 
West Virginia during the 1950s and 1960s. In describing and explaining Appalachian culture in his highly popular book, Yesterday's People, Weller pointed out the perils of subjectivism in describing another's culture. Unfortunately, after issuing his warning, he promptly became ensnared by that very trap when he announced his intention to "contrast various characteristics of the [Appalachian] folk culture with those of the middle class. ${ }^{, 28}$ In effect, Weller's characterization of Appalachian culture is but a projection of his own background and values onto the surface of an unfamiliar people. To a great extent, Weller's portrayal is based upon his own preconceptions of what Appalachian culture should be. Thus, even though Weller employed sociological jargon in his analysis, his writing is as mythical as the local color authors of the late nineteenth century. ${ }^{29}$

What then did Weller have to say about Appalachian people and their culture? A key point in his analysis is the idea that mountain people have been psychologically different from their "mainstream" counterparts since the earliest days of settlement and that those differences became more pronounced with the passage of time. He further explained that unlike most people, the earliest Appalachian pioneers generally had little interest in settling down to a stable lifestyle that revolved around the accumulation of wealth and the pursuit of comfort. Instead, according to Weller, they worked to create a life devoid of law and restraint. "No hierarchy, authorities, or experts were allowed to form in this society" which adopted a Leveller outlook granting equal status to all. Weller went on to explain that during the first generation or two of settlement,

${ }^{28}$ Jack E. Weller, Yesterday's People: Life in Contemporary Appalachia Lexington: University of Kentuky Press, 1965), 3, 5.

${ }^{29}$ Batteau, "Appalachia and the Concept of Culture," 11. 
Appalachian people enjoyed a good life free from outside interference. In time, however, their physical isolation led to social, cultural, economic, educational, and religious isolation from the rest of the country. Within such an environment, inbreeding became prevalent, modern commerce failed to develop, and the poorly educated people fell prey to unscrupulous land agents from the timber and coal companies. Echoing the deterministic voice of Semple, Weller concluded that "the mountaineers were a people apart, molded by the peculiar forces of the terrain, the pressure of economics, and the lack of contact with outsiders." Unlike "regular" middle-class Americans, Weller identified what he believed to be a distinct, defective subculture that condemned many mountain people to lives of poverty. Such a conclusion left the altruistic Weller wondering how to help a group of people "who still live by seventeenth-century social and economic codes" on an unconquered frontier $?^{30}$

As the American War on Poverty drew increasing national attention to the Appalachian Mountain region during the late 1960s and early 1970s, colleges and universities responded by adding courses and specializations on the topic. It is significant that this renewed academic interest in Appalachian studies coincided with the emergence of the New Social History. With its emphasis on diversity, culture, and quantitative methodology, it did not take long before scholars began to challenge the validity of some of Appalachia's most enduring myths. It is within this larger historiographic context that this dissertation reexamines the nature and duration of the Appalachian frontier experience by seeking to establish an intermediate position situated somewhere between the traditional concept of Appalachia being a prolonged and stagnated frontier and the revisionist image of Appalachian settlers experiencing a rapid, almost ephemeral,

\footnotetext{
${ }^{30}$ Weller, Yesterday's People, 5, 10-14, 26, 28.
} 
period of frontier living conditions. Only by considering the far reaching effects and influences of Indian-associated violence on the settlers' daily lives can a more balanced image of the western Virginia frontier be achieved. Perhaps the best place to begin this reassessment is with a discussion on how to conceptualize the western Virginia frontier. 


\section{Chapter Two}

\section{Conceptualizing the Western Virginia Frontier}

The term "frontier" is one of those "loaded words" in the English language that carries far more cultural meaning than the simple letters suggest. To many Americans, the word often invokes images of a desolate landscape occupied by dangerous wild animals and lurking Indians. It is a place to be feared, conquered, and made "civilized" by clearing the forest, building homes, erecting fences, killing the wolves, and "dealing" with the "Indian problem." 31 Although such an image is useful to those seeking an exciting setting for their novels, movies, and other tales of pioneer heroics, it holds little of analytical value to the historian.

For modern scholars, the frontier is much more than a place. Frontiers also possess a dynamic human element. In other words, a frontier is a meeting ground where distinct societies, or cultural groups, interact with one another through a variety of processes including acculturation, assimilation, miscegenation, race prejudice, conquest, imperialism, and colonialism. ${ }^{32}$ Sometimes the contact is peaceful, but more often it is marked by conflict and a struggle to achieve economic, cultural, and political dominance. In this quest for dominance, the marginalization of the subordinate group can assume many forms. Consider the following event from a century ago.

On an overcast day in the spring of 1919, more than two hundred people gathered near the

${ }^{31}$ Richard L. Hann, "Another Example of Stereotypes on the Early American Frontier: The Imperialist Historians and the American Indian," Ethnohistory 20 (Spring 1973): 144, 148.

${ }^{32}$ Jack D. Forbes, "Frontiers in American History and the Role of the Frontier Historian," Ethnohistory 15 (Spring 1968): 207. 
mouth of Pricketts Creek in Marion County to attend the formal dedication of a historical monument marking "the site of Prickett's Fort built in 1774 on the land of Jacob Prickett." Judge James R. Moreland, the state president of the Sons of the American Revolution, delivered the keynote address. In a patriotic speech, he honored the memories of those men and women who had helped to settle the upper Monongahela Valley during the Revolutionary era. What he failed to emphasize was that the region had already been settled by Native Americans for thousands of years prior to the arrival of the Prickett family or any other Europeans. ${ }^{33}$

Although Moreland most likely did not consciously intend it, his failure to recognize the existence and significance of the Indians is a type of marginalization. ${ }^{34}$ Unfortunately, Moreland's speech is not an isolated occurrence. Throughout the twentieth century, scholars and writers have argued that western Virginia did not really have a permanent native population. Instead, they contended that white pioneers only encountered "foreign" Indians who visited the region to hunt, "camp, or wage war. ${ }^{35}$ This "hunting ground myth" became so pervasive that the state department of education even incorporated it into the West Virginia public school curriculum. ${ }^{36}$

33،"Historical Monument erected by Sons of the Revolution Dedicated with Appropriate Ceremonies," The Fairmont Times, 27 June 1919; "Prickett's Fort Marker Dedicated," The Fairmont West Virginian, 27 June 1919. The monument can still be seen at Prickett's Fort State Park near Fairmont, West Virginia.

${ }^{34}$ Although Moreland did not intentionally denigrate the Indians by failing to recognize their significance in American history, his omission nonetheless smacks of the racism inherent in the Imperialist school of American history which focused its attention on the growth and development of British society and institutions in the North American colonies. See Hann, "Another Example of Stereotypes," 145.

${ }^{35}$ Daniel B. Fowler, "An Old Shawnee Town in West Virginia," West Virginia Archeologist 28 (Spring \& Fall 1979): 24.

${ }^{36}$ Tyndall V. Samerson, comp., The Open Sesame Question and Answer Book on West 
Fortunately, modern scholarship from several disciplines has revealed that the hunting ground myth is largely a misconception. Far from being a land devoid of native people, western Virginia had an active and thriving Indian population which only gradually succumbed to European dominance over a hundred and fifty year period ending in the late eighteenth century. It is important to understand that the frontier phase of western Virginia history did not begin in 1749 when Stephen Sewel and Jacob Marlin became the first Euro-Americans to take up residence. ${ }^{37}$ Rather, the frontier period actually started around the mid-seventeenth century when European diseases, trade goods, and explorers began to penetrate the region. ${ }^{38}$ The problem with the shortsighted hunting ground myth is that it emphasizes only the final few decades of the frontier era when the native population had already suffered catastrophic decimation and upheaval from a combination of exposure to alien germs, fur trade inspired dependency, intertribal warfare, forced migrations, European warfare, and the clash between European and Native American cultural values. All of these factors will be discussed more fully later in this chapter.

In a fundamental way, the hunting ground myth bears close semblance to Frederick Jackson Turner's highly popular, albeit erroneous conception of what constitutes a frontier. In his 1893 essay entitled "The Significance of the Frontier in American History," the Wisconsin

Virginia (St. Mary's, W. Va.: West Virginia Club Concern, 1955), 19-20.

${ }^{37}$ John Stuart, "Memorandum, 1798, July $15^{\text {th }}$," in Ruth Woods Dayton, Greenbrier Pioneers and Their Homes (Charleston, W. Va.: West Virginia Publishing, 1942), 367

${ }^{38}$ There is little doubt that European hunters and explorers had visited western Virginia prior to the celebrated 1671 expedition of Thomas Batts and Robert Fallom. While exploring near the New River on 13 September, they discovered the initials MA and NI written with coal on two trees and "several other scrablements" carved into the trunks of others. [Robert Fallam], "John Clayton's Transcript of the Journal of Robert Fallam," in Clarence Walworth Alvord and Lee Bidgood (Cleveland: Arthur H. Clark), 1912), 188. 
historian argued that a distinct American culture first emerged on the frontier where primitive living conditions had forced settlers to culturally adapt to a new environment in order to survive. Although there is little doubt that the frontier experience exerted influence on the development of the American character, Turner's use of white population density to define the boundaries of the frontier is problematic. Citing the United States Census Bureau, Turner identified the frontier as that territory which lies adjacent to any region having at least two white inhabitants per square mile. In other words, any territory with fewer than the requisite number of white settlers was considered to be part of the frontier regardless of how many Indians might reside there. In fact, Turner even went so far as to categorize the Indians' tribal territories as uninhabited free land open to white settlement. ${ }^{39}$ Herein lies the connection between Turnerian thought and the hunting ground myth. Not only do both models suffer from a myopic Eurocentric perspective, but they also essentially function as rationales for the seizure of Indian lands with little heed for the culture, history, significance, and even existence of the native population. At its most basic level, the West Virginia hunting ground myth is but a particularized local manifestation of the philosophy of dispossession and marginalization popularized by Frederick Jackson Turner and carried out by the people and government of the United States.

To correct this problem in how we conceive the frontier, we must at least try to purge our frontier paradigm of Euro-American bias. ${ }^{40}$ One way of doing this is to shift the emphasis of Turner's model away from white population density and biological race in favor of human

${ }^{39}$ Frederick Jackson Turner, "The Significance of the Frontier in American History" in The Turner Thesis: Concerning the Role of the Frontier in American History, $3^{\text {rd }}$ ed., ed. George Rogers Taylor (Lexington, Mass.: D.C. Heath, 1972), 3-4.

${ }^{40}$ This is much easier said than done. 
diversity and cultural ethnicity. By recognizing the value and significance of every cultural group, the frontier can be envisioned as a dynamic meeting ground where two or more distinct societies relate with one another and oftentimes compete for dominance. ${ }^{41}$ In addition, by defining frontiers in ethnic/cultural terms, it eliminates the idea that North American frontiers are somehow exceptional when compared with frontiers in other parts of the world. Thus, the historical processes at work on the border between the Shawnees and Virginians are suddenly not that much different than those found on the frontiers which existed between Catalans and Moors or Turks and Magyars. ${ }^{42}$ "Civilization," "savagery," and population density have little to do with defining frontiers.

If cultural differences delineate frontiers, then it is important to understand what culture is and how it relates to the historical process. Cultural geographers have devised several models that typically divide culture into three parts: artifacts (physical objects and technology), sociofacts (customs and standards of interpersonal relationships), and mentifacts (knowledge, language, and religion). Although such a paradigm is essentially correct, it fails to convey the sense of motion associated with historical processes. In other words, popular conceptions of culture often present it as a given set of traits, or a portrait in time, rather than a motion picture. It must be emphasized that every culture is always in a state of flux whether it be from internal innovation, acculturation to external ideas, or some form of accommodation whereby native and external ideas are synthesized into a new cultural trait. Regardless, the important point is that the cultural traits of

\footnotetext{
${ }^{41}$ Howard Lamar and Leonard Thompson, eds., The Frontier in History: North America and Southern Africa Compared (New Haven: Yale University Press, 1981), 7.

${ }^{42}$ Forbes, "Frontiers in American History," 208.
} 
every society are constantly changing to meet the evolving needs of that society. ${ }^{43}$

Although the conditions of daily life are subject to change everywhere, cultural change is particularly rapid within a frontier environment. Four primary factors influence this rate of cultural change. First, frontiers are characterized by cultural plurality. Wherever cultural diversity exists, so does cultural borrowing whereby the various ethnic groups selectively adopt cultural traits from one another. Trans-Allegheny settler Joseph Doddridge, for example, reported that some of the men from the settlements had adopted the use of Indian clothing when they went hunting. ${ }^{44}$ European settlers also began using Indian canoes, various herbal remedies, foods, and select vocabulary. ${ }^{45}$ Indians likewise embraced many elements of European culture, particularly technology. Some Shawnees by the early 1770s had even adopted European-style horizontal log cabins with gabled ends and shingled roofs for use during the cold winter months. ${ }^{46}$

Second, for at least one group of people, the frontier may represent a new physical environment. When settlers first crossed the Allegheny Mountains, they encountered a landscape unlike anything most had ever seen. The extensive old growth forests are a case in point. Colonel

${ }^{43}$ Arthur Getis, Judith Getis, Jerome D. Fellmann, Introduction to Geography, 6th ed. (Boston: McGraw-Hill Higher Education, 1998), 233-48.

${ }^{44}$ Joseph Doddridge, Notes on the Settlement and Indian Wars (1912: reprint, Parsons: W. Va.: McClain, 1976), 91-93.

${ }^{45}$ For a broad discussion of Indian cultural practices adopted by Euro-Americans, see Jack Weatherford, Indian Givers: How the Indians of the Americas Transformed the World (New York: Fawcett Columbine, 1988) and Jack Weatherford, Native Roots: How the Indians Enriched America (New York: Ballantine Books, 1991).

${ }^{46}$ David Jones, A Journal of Two Visits Made to Some Nations of Indians on the West Side of the River Ohio, in the Years 1772 and 1773 (Chillicothe: Ohio, Ross County Historical Society, 1946), 7; James H. Howard, Shawnee!: The Ceremonialism of a Native American Tribe and Its Cultural Background (Athens: Ohio University Press, 1981), 78-80. 
Henry Bouquet noted that "An European ... must have lived some time in the vast forest of America; otherwise he will hardly be able to conceive a continuity of woods without end."47

Third, migration to a distant frontier effectively removed people from the direct control of powerful colonial administrators. Relatively free from the reigns of outside domination, backcountry inhabitants could more freely adapt their attitudes and lifestyles to local conditions. ${ }^{48}$ In the upper Monongahela Valley, for example, the first permanent settlers lived for almost a decade without any form of effective local government. Without a sheriff or nearby courts, the trans-Allegheny settlers developed their own methods of dealing with criminals. An offender could be "hated out," or banished, from the settlements, or even be forced to "carry the American flag on his back," or in other words, receive thirteen stripes across the bare back with a whip or rod. By the same token, religious denominations organized on the basis of a distant Episcopalian hierarchy failed to exert much influence in the sparsely populated backcountry settlements of western Virginia. Instead, churches that emphasized congregational supremacy and lay ministers, such as the Baptists, Presbyterians, and Methodists, tended to attract the most adherents on the frontier. $^{49}$

Fourth, the violence, racial/ethnic intolerance, and warfare often associated with frontier living created a powerful impetus for the settlers in western Virginia to be pragmatic in their daily

${ }^{47}$ Colonel Henry Bouquet quoted in Fort Ligonier Association et al., War for Empire in Western Pennsylvania (Ligonier, Penn.: Fort Ligonier Association, 1993 ), 7.

${ }^{48}$ For insight into the relationship between peripheral geographic locations and the emergence of new cultural patterns, see Carlo Ginzburg, The Cheese and the Worms: The Cosmos of a Sixteenth Century Miller (Baltimore: Johns Hopkins University Press, 1980), 120.

${ }^{49}$ Otis K. Rice, The Allegheny Frontier: West Virginia Beginnings, 1730-1830 (Lexington: University Press of Kentucky, 1970), 279-280, 288-89. 
quest for physical security. In other words, they simply did whatever was necessary in order to survive the ravages of backcountry warfare. Survival strategies included a diverse array of tactics including the use of civilian refuge forts, long range scouting patrols, communal work parties, and selecting community leaders on the basis of their ability to fight Indians. On the frontier, survival hinged on the ability to adapt one's daily regime to the realities of life in a pluralistic, heavily forested, war zone remote from the centralizing powers of the colonial capital.

When envisioned in cultural terms, it becomes evident that the beginnings of frontier conditions can exist long before direct personal contact has been made between two previously distinct societies. In the case of western Virginia, the arrival of English colonists at Jamestown in 1607 set in motion a chain of events which indirectly brought catastrophic upheaval to the native Shawnees, Monetons, Monongahela, and Fort Ancient Indians who resided west of the Allegheny Mountains. The first link in this chain of destruction involved the introduction of alien diseases. Archeologists suspect that Susquehannock Indians from eastern Maryland and Virginia contracted diseases from the English and introduced them inadvertently into the native population of western Virginia during hunting and trading expeditions. ${ }^{50}$ Never having been exposed to microbes such as measles and small pox, virgin soil epidemics swept through the villages killing hundreds.

Evidence of this widespread death can be seen at the site of a seventeenth-century Indian village

${ }^{50}$ Stanley W. Baker, "Neale's Landing Site Ceramics: A Perspective on the Protohistoric Period from Blennerhassett Island," West Virginia Archeologist 40 (Fall 1988): 49-50; Michael B. Barber and Eugene B. Barfield, "Native Americans on the Virginia Frontier in the Seventeenth Century: Archeological Investigations along the Interior Roanoke River Drainage," in Diversity and Accommodation: Essays on the Cultural Composition of the Virginia Frontier, ed. Michael J. Puglisi (Knoxville: University of Tennessee Press, 1997), 148; Francis Jennings, "Susquehannock," in Northeast, vol. 15 Handbook of North American Indians, ed. Bruce G. Trigger (Washington, D.C.: Smithsonian Institution, 1978), 364. 
in the Kanawha Valley where archeologists discovered several mass graves with the largest containing almost forty bodies. Considering that the remains exhibited little evidence of trauma, the researchers concluded that these Indians had most likely died from disease. ${ }^{51}$

Despite the catastrophic impact that germs had on the Indians, anthropologists point out that human populations are resilient, and that given sufficient time under favorable conditions, they will naturally rebound. ${ }^{52}$ Unfortunately, the native people of western Virginia received no respite. Starting in 1662, the suffering of the Shawnees and other Indian groups in the upper Ohio Valley increased when Iroquois warriors from present New York began raiding their villages. ${ }^{53}$ Although many raids took place to gain captives or avenge the death of a relative, an important secondary reason for the Iroquois attacks relates to the fur trade that had developed in the eastern Great Lakes region during the early seventeenth century. ${ }^{54}$ At European trading posts, the Iroquois exchanged beaver skins for various goods with "the highest esteem and value" being placed upon guns, powder, lead, cloth, blankets, colorful wool stockings, and small brass kettles. ${ }^{55}$ As Iroquois dependence on European goods grew, they had little choice but to harvest ever-increasing numbers of furs. At first, they hunted and trapped beavers within their own

${ }^{51}$ Ronald W. Moxley, "The Orchard Site: A Proto-Historic Fort Ancient Site in Mason County, West Virginia,” West Virginia Archeologist 40 (Spring 1988): 32.

${ }^{52}$ Russell Thornton, "Aboriginal North American Population and Rates of Decline, ca. A.D. 1500-1900,” Current Anthropology 38 (April 1997): 311.

${ }^{53}$ Charles Callander, "Shawnee," in Northeast, vol. 15 Handbook of North American Indians, ed. Bruce G. Trigger (Washington, D.C.: Smithsonian Institution, 1978), 630.

${ }^{54}$ For a brief discussion of the blood feud within Iroquois' society, see Anthony F. C. Wallace, The Death and Rebirth of the Seneca (New York: Vintage Books, 1969), 44-45.

${ }^{55}$ Doc. His. N.Y., 4:170. 
territory, however, by 1640, the beaver population of present New York teetered on the brink of extinction. With their own beavers gone, the Iroquois hunters turned a covetous eye toward the territories of their neighbors. Starting in the late 1640s, they became embroiled in a series of "Beaver Wars" that pitted them successively against all of their neighboring tribes including the native people of trans-Allegheny Virginia. ${ }^{56}$

In addition to the Iroquois' attacks into western Virginia, there is also historic evidence of Cherokee Indians raiding Shawnee villages during the later seventeenth century. In the spring of 1674, for example, a band of sixty Cherokee warriors attacked a Shawnee village located somewhere within a few days travel of present Wayne County, West Virginia. Although the Cherokee attack occurred with great vigor, the Shawnees, armed principally with arrows, flint knives, and war clubs, managed to repulse the assault. As the routed Cherokees fled the battlefield, they left behind a wounded young warrior who the Shawnees subsequently took captive. Upon closer examination of their prisoner, it became evident that this was no ordinary Cherokee. Although dressed as a warrior and adorned with body paint, this man wore his hair long like a woman. The Shawnees likewise found the man's tools and weapons to be highly unusual. Never before had these particular Shawnees seen a steel knife, iron hatchet, or a musket. After confiscating these strange implements, the Shawnees removed their captive's war paint with an abrasive mixture of ashes and water. Much to their surprise, they found that their prisoner had pale skin! These particular Shawnees had encountered their first European, a young

\footnotetext{
${ }^{56}$ Paul A. W. Wallace, Indians in Pennsylvania (Harrisburg: Pennsylvania Historical and Museum Commission, 1993), 99-100.
} 
indentured servant from Virginia by the name of Gabriel Arthur. ${ }^{57}$

Although illiterate, Arthur appears to have had some skill as a mediator between English and Indian society. Within a short time, he gained a degree of trust and his weaponry was returned to him. Then in an astute move based presumably on his knowledge of the importance of gift giving within Indian society, Arthur gave his hatchet and knife to one of the Shawnee leaders. Arthur also took the opportunity to indicate through sign language that his people who lived toward the rising sun valued beaver skins and would gladly trade for them. Four beaver skins could gain the Shawnees a knife and eight could get them a hatchet. Apparently taking great joy at the prospect of obtaining iron tools, the Shawnees released Arthur to return to his own people. ${ }^{58}$

It is unknown whether the trade relations brokered by Arthur ever came to fruition because within a few years, the disease-weakened Shawnee nation would be split asunder. The dispersal of the Shawnees likely occurred because of a combination of factors including the Beaver Wars, continued Cherokee raiding, and voluntary migrations to places with more convenient access to European trade goods. Thus, by the end of the seventeenth century, Shawnees lived in a number of widely dispersed locations including present Illinois, Alabama, Florida, and South Carolina. Hundreds more Shawnees yet remained in the Ohio Valley with a particular concentration of villages in the vicinity of the Cumberland River. ${ }^{59}$

\footnotetext{
${ }^{57}$ Wood to Richards, 22 August 1674, in Alvord, First Explorations of the TransAllegheny, 223.

${ }^{58}$ Wood to Richards, 22 August 1674, in Alvord, First Explorations of the TransAllegheny, 223-24.

${ }^{59}$ For a detailed examination of the migrations of the various Shawnee bands, see Jerry E. 
During the final two decades of the seventeenth century, the colonial government of New York along with traders in Albany made a concerted effort to draw the remaining Ohio Valley Shawnees into their economic sphere of influence. In the summer of 1684, Governor Thomas Dongan urged his Iroquois allies to form alliances with the "further Indians" of the Ohio Valley and Great Lakes region and to permit them to come to Albany to trade. ${ }^{60}$ Possibly in response to this overture, in the early 1690s, a delegation of "Showannos came to New Yorke to make peace. ${ }^{\prime 61}$ With the establishment of relations between the Albany traders and Shawnees, former Indian interpreter Arnout Viele left New York in the fall of 1694 with a load of trade goods and a couple of Shawnees guides to lead him to their Ohio Valley villages. ${ }^{62}$ Fifteen months later, Arnout emerged from the wilderness accompanied by "seaven hundred of ye said Shanwans Indians loaden wth beavor and peltries. ${ }^{, 63}$ They settled along the Delaware River in Pennsylvania under the benevolent oversight of William Penn.

Over the next two decades, many of the widely scattered Shawnee bands migrated into eastern Pennsylvania where the nation became somewhat more consolidated. ${ }^{64}$ They, like other groups of refugee Indians, had heard stories of how William Penn and the pacifist Quakers

Clark, The Shawnee (Lexington: University Press of Kentucky, 1993), Ch. 2.

${ }^{60}$ Peter Wraxall, Abridgement of the Indian Affaires Contained in Four Folio Volumes, Transacted in the Colony of New York, From the Year 1678 to the Year 1751, ed. Charles H. McIlwain (Cambridge: Harvard University Press, 1915), 13.

${ }^{61}$ Fletcher to the Five Sachems of the Five Nations, 31 July 1693, Doc. His. N.Y., 4:51.

${ }^{62}$ Helen Broshar, "The First Push Westward of the Albany Traders," The Mississippi Valley Historical Review 7 (December 1920): 238-39.

${ }^{63}$ Doc. His. N.Y., 4:99. 
reached toleration toward all people. According to the resident Delaware Indians, Penn's colony became a "delightful" place for any Indian peoples seeking asylum. ${ }^{65}$ Penn urged everyone to treat the Indians well. "Don’t abuse them, but let them have Justice.",66

Despite Penn's noble intentions, not every Pennsylvanian adhered to his admonitions. Provincial Secretary James Logan, for example, secretly used the power of his office to remove the Indians from choice pieces of land. ${ }^{67}$ Common settlers likewise disregarded the law at times by squatting on the Indians' territory without making any effort to first purchase it. ${ }^{68}$ Other problems arose from settlers' free-range cattle and hogs damaging the Indians' unfenced cornfields. As the pressure mounted, the refugee Shawnees decided ultimately to leave eastern Pennsylvania and return to their tribal homeland in the Ohio Valley. Between 1722 and 1734, scattered bands of Shawnees gradually moved westward across Pennsylvania in a sporadic migration. ${ }^{69}$ Many Delaware Indians, who had previously not lived in the Ohio Valley, also moved west at this time to escape white encroachment on their towns and hunting territories.

${ }^{64}$ Clark, Shawnee, 121-22.

${ }^{65}$ John Heckewelder, An Account of the History, Manners, and Customs of the Indian Nations Who Once Inhabited Pennsylvania and the Neighboring States (Philadelphia: Philosophical Society, 1819), 78.

${ }^{66}$ Penn to The Committee of the Free Society of Traders, 1683, in Narratives of Early Pennsylvania, West New Jersey, and Delaware, 1630-1710, ed. Albert Cook Myers (New York: Barnes and Noble, 1953), 236.

${ }^{67}$ Francis Jennings, The Ambiguous Iroquois Empire: The Covenant Chain Confederation of Indian Tribes with English Colonists from its beginnings to the Lancaster Treaty of 1744 (New York: W.W. Norton, 1984), 271.

${ }^{68}$ Wallace, Indians in Pennsylvania, 143.

${ }^{69}$ Clark, Shawnee, 22. 
Thus, by 1749 when the very first documented European settlers crossed the mountains from the Shenandoah Valley into western Virginia, the region had already been re-occupied by diminished numbers of highly mobile mixed villages of Shawnee, Delaware, and Ohio Iroquois known locally as the "Mingo."

For the Shawnee Indians who had already suffered a hundred years worth of catastrophic population loss and upheaval, the frontier period of "West Virginia" history did not begin in 1749 with the arrival of European settlers. On the contrary, it began in the mid-seventeenth century when the Shawnees first encountered white trade goods, European germs, and frontiersmen such as Gabriel Arthur. As previously noted, frontiers are defined on the basis of cultural contact, not the physical presence of settlers.

Although European guns and diseases took a terrible toll on the Shawnee people, a further less tangible challenge came in the form of alien ideas. One of the most irreconcilable cultural differences between the English and Indians was the incompatibility of their respective ideas regarding land ownership and private property. To a great extent, this lack of mutual understanding can be attributed to the fact that individual concepts of property ownership are as much an ingrained cultural trait as is language or national dress. Both sides intertwined religious beliefs with their property customs and that only complicated the matter. In addition, English attitudes toward dispossession also contained elements of racism, avarice, and arbitrary rationalization. To better understand the depth of this cultural divide, it would be beneficial to explore English and Native American attitudes toward tribal territory, private property, and land ownership. 
When English colonists first arrived in the New World, they failed at the outset to fully understand the political organization of the native people. By arbitrarily lumping together all Indians who shared a common dialect into a unified tribal "state" under the leadership of a single chief or "king," the English conceptualized the tribes to be analogous to European states, such as Scotland or Bavaria, albeit less sophisticated. As states, the English believed the various tribes held title to identifiable tracts of territory that could be legally sold or traded away by the tribal government. To purchase tribal land, the English merely needed to locate the political leadership of the tribe and negotiate the terms of the property transfer. A treaty, either written or verbal, often added legitimacy to the agreement. ${ }^{70}$ In 1683 , William Penn wrote "Their Government is by Kings" and that "Some Kings have sold, others presented me with several parcels of Land." Understandably, the English perceived the structure of Native American government and land ownership from a Eurocentric perspective.

It is far more accurate to envision Eastern Woodland Indian politics as having revolved around politically autonomous villages that controlled their own specific territories independent of any larger tribal organization. Within these village territories, two systems of land tenure coexisted. First, the inhabitants of each village collectively owned a large tract of "hunting territory" where anyone from the village could hunt for deer, fish, gather firewood, or pick berries with few limitations. ${ }^{72}$ Second, each extended family, generally under the leadership of a

\footnotetext{
${ }^{70}$ A. L. Kroeber, "Nature of the Land-Holding Group," Ethnohistory 2 (Autumn 1955): 303.

${ }^{71}$ Penn to The Committee of the Free Society of Traders, 1683, in Narratives of Early Pennsylvania, 233.

${ }^{72}$ William Cronin, Changes in the Land: Indians, Colonists, and the Ecology of New 33
} 
matriarch, cultivated its own private parcel of land. Fallow fields or trees sometimes separated the farmland of one extended family from another. Among the Shawnees, extended families worked together to plant a crop, but once in the ground, they assigned specific plots to the various households within the extended family. ${ }^{73}$ These privately owned fields remained in the possession of the various extended families for as long as they used it for agricultural purposes. When a family abandoned a field due to soil depletion or the relocation of a village, the ownership of that land reverted back to the community. A village council then granted the matriarch a new parcel of farmland. In effect, the private ownership of land among the Eastern Woodland Indians can be viewed as a temporary condition related to the farming of that land. When cultivation ended, so did personal and family possession. ${ }^{74}$

The English practice of selling land was foreign to the Eastern Woodland Indians who generally regarded land as a gift from the Great Spirit. According to one Indian chief,

land cannot be sold. The Great Spirit gave it to his children to live upon, and cultivate, as far as is necessary for their subsistence; and so long as they occupy and cultivate it, they have a right to the soil - but if they voluntarily leave it, then any other [Indian] people have the right to settle upon it. ${ }^{75}$

In short, the Indians simply could not cede title to their hunting grounds because they believed they did not possess it. The current generation of villagers lived as trustees of the land. They

England (New York: Hill and Wang, 1983), 63-64.

${ }^{73}$ Erminie Wheeler Voegelin, "The Place of Agriculture in the Subsistence Economy of the Shawnee," Papers of the Michigan Academy of Science, Arts, and Letters 24 (1941): 518-19.

${ }^{74}$ R. Douglas Hurt, Indian Agriculture in America: Prehistory to Present. Lawrence: University Press of Kansas, 1987), 65-66.

${ }^{75}$ Black Hawk, Life of MA-KA-TAI-ME-SHE-KIA-KIAK or Black Hawk (1834: reprint Iowa City, Iowa: State Historical Society of Iowa, 1932), 88. 
could use the land, care for it, and perhaps even permit Indians from other villages to live there, but they could not sell it to the English colonists. The theoretical inability of the Indians to sell their land did not preclude them from giving it away as a gift or leasing it to white settlers. Even in these cases, the Indians considered the land transfer to be only temporary, hence the term "Indian giver." The English consistently failed to understand that when the Indians gave them land as a gift or token of friendship, they did not cede ownership of that land in perpetuity. Rather, they merely granted the English a temporary right to use that land in much the same fashion that village chiefs granted matriarchs temporary title to land. Like Indian farmers, the English had only limited rights to any land "given" to them. For example, Roger Williams correctly pointed out that even though he had given a "gratuity" to a sachem of the local Narragansett Indians for the use two islands for grazing hogs, no transfer in land ownership had actually taken place. ${ }^{76}$ If an English farmer quit cultivating that land or if he failed to comply with the terms of an agreement, the land reverted back to the Indian village. In essence, Indians did not alienate themselves from the land.

Unlike the Indians, the English looked upon land as a commodity that could be privately owned, bought, sold, claimed, traded, given away, or even conquered. But by what authority did English monarchs and colonial administrators claim the ability to dispose of land occupied by native people? The answer to this question is twofold. First, English kings and queens claimed to possess a special type of divine grace that permitted them to act as gods on earth. In 1610, James I explained to Parliament "The state of monarchy is the supremest thing on earth. For

\footnotetext{
${ }^{76}$ Williams to Winthrop, [June 1638], Letters of Roger Williams, 1632-1682, ed. John Russell Bartlett (Providence, Narragansett Club, 1874), 104.
} 
kings are not only God's lieutenants upon earth, and sit upon God's throne, but even by God himself they are called gods." ${ }^{, 77}$ Theologians in England buttressed this position by arguing that kings not only derived their authority from God, but also actually exercised the same authority as God. The only real difference between the two pertained to the source of that authority. God, as the Supreme Being, derived His authority from His divine nature. Kings and queens, on the other hand, received their divine authority through grace. ${ }^{78}$ Thus, when English monarchs granted patents for land in the New World, they did so by the grace of God. Elizabeth I invoked her "especial grace" when she issued a patent to Sir Humphrey Gilbert in 1583 just as James I "by the grace of God" bestowed a patent upon the Virginia Company in April $1606 .{ }^{79}$ Likewise, in 1671, explorers Thomas Batts and Robert Fallam proclaimed English sovereignty over western Virginia in the name of "his sacred majesty," Charles II, "by the grace of God." 80

Monarchs also claimed the ability to colonize foreign lands on the basis of their "superior" religion. According to contemporary theory, Christian kings possessed the right of eminent

\footnotetext{
${ }^{77}$ King James I, "A Speech to the Lords and Commons of the Parliament at White-Hall (1610)," in Divine Right and Democracy: An Anthology of Political Writings in Stuart England, ed. David Wootton (London: Penguin Books, 1986), 107.

${ }^{78}$ Ernst H. Kantorowicz, The King's Two Bodies: A Study in Medieval Political Theology (Princeton: Princeton University Press, 1957), 48.

${ }^{79}$ Queen Elizabeth I quoted in Seed, "Taking Possession and Reading Texts: Establishing the Authority of Overseas Empires," The William and Mary Quarterly 49 (April 1992): 186; King James I, "Letters Patent to Sir Thomas Gates, Sir George Somers and others, for two several Colonies and Plantations, to be made in Virginia, and other parts and Territories of America," in The Genesis of the United States, ed. Alexander Brown (Boston: Houghton, Mifflin and Company, 1890), 52.
}

${ }^{80}$ [Robert Fallam], "Explorations Beyond the Mountains," The William and Mary Quarterly 15 (April 1907): 240. 
domain over any territory occupied by "heathens." Unlike the Catholic French and Spanish, the Protestant English did not base the legitimacy of their land seizure on converting natives to Christianity. ${ }^{81}$ Merely being Christian provided sufficient justification for some people to force the Indians from their land.

Although the English used Christianity to justify taking Indian land, colonial administrators and settlers placed the greatest emphasis on "right of possession," the idea that physical occupation of land created a right to own that property. This idea is reflected in English common law where the words "property" and "possession" are thought to be virtually synonymous. ${ }^{82}$ Consider the old English legal adage that "possession is eleven points of the law" (out of a possible twelve). ${ }^{83}$ This is where English property law and Roman law diverged. Ancient Roman law differentiated between having the right to possess property and actually possessing that property. By the seventeenth century in England, on the other hand, the two categories had merged so that physical possession created a degree of legal possession. In this regard, England stood unique among European countries in that a papal bull or royal charter granting land tended to be less important than actually having colonists occupying and holding that property. ${ }^{84}$

Much like the Eastern Woodland Indians, the use of land by Englishmen established a legitimate basis for their possession of that land. But what constituted legitimate land use? For

${ }^{81}$ Patricia Seed, “Taking Possession and Reading Texts,” 188.

${ }^{82}$ Frederick Pollock and Robert Samuel Wright, An Essay on Possession in the Common Law (Oxford: Clarendon Press, 1888), 5.

${ }^{83}$ The Oxford English Dictionary, 2d ed., s.v. "possession."

${ }^{84}$ Patricia Seed, “Taking Possession and Reading Texts," 189-90. 
the English, usage involved activities such as building homes, clearing land, and planting crops. In general, a person's right to a particular tract of land increased with the number of "improvements" that he had made. Consider the 1779 Virginia land law that enabled squatters on the frontier to obtain deeds provided they had either "made a crop of corn" or "resided there at least one year since the time of their settlement." ${ }^{85}$ Thus, settler Thomas Batten, Jr. received title to his homestead through "the right of residence to include his Improvement made in the year 1772."

The English placed particular emphasis on agricultural activity as evidence that ownership of land had been established. The source of this attitude is tied closely to the English interpretation of Genesis 1:28 which reads “. . . and God said unto them, Be fruitful and multiply and replenish the earth, and subdue it." Anglican minister Richard Eburne explained that this commandment to Adam constituted a grand charter which bestowed upon his [Christian] descendants "the privilege to spread themselves from place to place, and to have, hold, occupy, and enjoy any region or country whatsoever which they should find either not occupied. ${ }^{.87}$ Of course, a fundamental difference existed between the English and Indian conceptions of what constituted "replenishing" and "subduing" the land. The English associated replenishment with amending the soil in some manner so as to improve its fertility. Disregarding stories that New England Indians may have fertilized their crops with dead fish, the English emphasized the absence of familiar agricultural practices, such as spreading manure and planting nitrogen fixing

\footnotetext{
${ }^{85}$ William Waller Hening, ed., The Statutes at Large; Being a Collection of All the Laws of Virginia, 1619-1792 (Richmond: 1809-23), 10:40.

${ }^{86}$ Quoted in Earl L. Core, The Pioneers, vol. 2 of The Monongalia Story: A Bicentennial History (Parsons, W. Va.: McClain, 1976), 199.

${ }^{87}$ Quoted in Patricia Seed, Ceremonies of Possession in Europe's Conquest of the New
} 
cover crops. Thomas Harriot pointed out these differences when he observed that the Virginia Indians "neuer fatten [the ground] with mucke, dounge or any other thing; neither plow nor digge it as we in England." ${ }^{88}$ Thus, by emphasizing cultural differences in farming techniques, the English argued that the Indians did not really use or own the land, but instead only occupied it like animals.

As disparate as they may initially appear, a common thread unites Turnerian thought, the hunting ground myth, and colonial English attitudes toward private property and land use: they all conceptualized the frontier in such a way as to marginalize the Indians through a form of denial. Frederick Jackson Turner, for example, marginalized the Indians by denying them significance in defining the frontier. English colonizers and settlers, on the other hand, denied the Indians their humanity by considering them to be "animalistic savages" with no property rights. Worse yet, the hunting ground myth went even one step further by denying the very existence of a native Indian population in western Virginia. At their most fundamental levels, the denial of the Indians' significance, humanity, and existence are but convenient mental constructs which facilitated the alienation of the Indians from their land and natural resources. When former Secretary of State William Learned Marcy penned the words "To the victor belong the spoils of the enemy," he could just as well have added that to the victor also goes the writing of the history. ${ }^{89}$ As products of the dominant group, it is of little surprise that most traditional frontier narratives relegate the

World (New York: Cambridge University Press, 1995), 31-33.

${ }^{88}$ Thomas Harriot, A Brief and True Report of the New Found Land of Virginia (New York: Dover Publications, 1972), 14.

${ }^{89}$ Quoted in The Oxford Dictionary of Quotations (New York: Oxford University Press, 1941), 329. 
Indians to a marginal role in history by portraying them as little more than adversaries, or "props," in one-sided celebrations of pioneer heroics. ${ }^{90}$ By presenting the Indians in this manner, they are construed as passive ingredients in the frontier process. In other words, like unbroken forests, wild animals, and untamed rivers, the Indians of popular imagination are presented as objects which pioneers overcome, or act upon, as they conquer the frontier. Although the settlers did indeed "act upon" the Indians in their quest for dominance, it must be emphasized that they also "reacted" to the challenges posed by the Indians. In this regard, both Indians and settlers played important and active roles in creating the Appalachian frontier experience.

\footnotetext{
${ }^{90}$ Puglisi, Diversity and Accommodation, 6.
} 


\section{Chapter Three}

\section{Shawnee Culture and the Ceremonialism of Violence}

The Euro-American conception of Native Americans has long been characterized by a strange duality. On the one hand, many Europeans have looked upon Indians as Rousseau's noble savage, a people who lived in the state of nature, untainted by the complexities and corruptive influences of "modern" life. Yet at the same time, others have scorned the Indians due to their alleged tendency toward violence, lack of "civilization," and "heathen" religious beliefs. In 1683, for example, William Penn claimed that the Indians' propensity for revenge and ability to conceal "their own Resentments" even exceeded that of the Italians. ${ }^{91}$ Likewise, the missionary David Jones who visited the Shawnees during the early 1770 s not only described their "cruelty to captives," but also explained how "it was not uncommon for [Indian] women to hang or drown their children, when they did not like them, and never . . . so much as bury them." ${ }^{, 92}$ More than two hundred years later, the publishers of a book on the eastern frontier described the Shawnee Indians on their book cover as being "warlike." 93 Another recent author went even further when he characterized the Iroquois as "the Nazi of the Eastern United States" who ruled the Indian

\footnotetext{
${ }^{91}$ Penn to The Committee of the Free Society of Traders, 1683, in Narratives of Early Pennsylvania, West New Jersey, and Delaware, 1630-1710, ed. Albert Cook Myers (New York: Barnes and Noble, 1953), 232.

${ }^{92}$ David Jones, A Journal of Two Visits Made to Some Nations of Indians on the West Side of the River Ohio, in the Years 1772 and 1773 (Chillicothe: Ohio, Ross County Historical Society, 1946), 17.

${ }^{93}$ William Hintzen, A Sketchbook of . . . The Border Wars of the Upper Ohio Valley: 1769-1794, Conflict and Resolutions (Manchester, Conn.: Precision Shooting, 1999), back cover.
} 
nations they conquered "with an iron fist." Indian as a "warlike brute" or a "noble savage," it resulted in the same condescension and marginalization. After all, a "noble savage" is a "savage" nonetheless.

Although brutality and violence indeed existed within Indian societies, just as it did among those of Europeans and Africans, popular conceptions of that violence understandably fail to place it within a proper cultural context. Whenever the Indians committed particular acts of violence related to warfare, blood vengeance, torture, or the taking of captives, it typically involved deeply held ceremonial practices and belief systems. Thus, in order to better comprehend the rationale that underlay Indian-perpetrated violence, we must first acquire an understanding of who the Indians were, how they organized themselves socially, how they provided for their fundamental needs, and why they reacted as they did to the incursion of EuroAmerican settlers into the upper Ohio Valley during the eighteenth century. In the process, it becomes apparent that even though the Indians sometimes committed acts of great violence, by no means were they the animalistic savages that haunted the imaginations of colonial settlers and their descendants. As the dominant Indian group on the western Virginia frontier, particular emphasis is placed upon the Shawnees. Although all Shawnees spoke the same language and shared a common culture, they possessed a very decentralized political structure. When compared with relatively well-integrated Indian groups such as the Cherokees and Iroquois, the Shawnee nation barely existed as a unified tribe. The Shawnees comprised five major political divisions, or septs, that occasionally acted in concert, but more often acted autonomously.

${ }^{94}$ John A. DeMay, The Settlers' Forts of Western Pennsylvania (Apollo, Pa.: Clossen Press, 1997), 42. 
Although the spelling varies somewhat according to the source, the septs are frequently written as the Thawegila, Chalagawtha, Kispokotha, Maykujay, and Peckuwe. In many ways, each sept acted as a tribe unto itself. Not only did they have their own principal chiefs and councils of elders, but they also controlled their own diplomatic relations with other Indians and Europeans. In addition, each sept customarily populated a primary village named after that sept. Thus, the principal village of the Chalagawtha Shawnees was usually called Chillicothe while that of the Thawegila Shawnees was called Sewickley. The fact that the Shawnees migrated widely throughout the colonial period accounts for the many occurrences of "Chillicothe," "Sewickley," and "Piqua" on modern maps of Ohio and Pennsylvania. ${ }^{95}$

The traditional structure and functions of the various Shawnee septs are not entirely clear. According to Shawnee mythology, each sept originated long ago as an individual whose descendants now collectively bear that person's name. Although the eighteenth-century Shawnee leaders Black Hoof and Tenskwatawa both denied that the septs had been created to serve a political purpose, other informants have described how each sept theoretically fulfilled a separate political role within the overall Shawnee nation. ${ }^{96}$ For example, Thomas Wildcat Alford, a college-educated Shawnee born shortly before the Civil War, explained that the Thawegila and Chalagawtha, being the most powerful of the septs, "had charge of political affairs and all matters that affected the tribe as a whole." Consequently, the principal chief of the nation had to come

${ }^{95}$ James H. Howard, Shawnee! The Ceremonialism of a Native American Tribe and its Cultural Background (Athens: Ohio University Press, 107-8; Jerry Clark, The Shawnee (Lexington: University Press of Kentucky, 1977), 33.

${ }^{96}$ C. C. Trowbridge, Shawnese Traditions, ed. Vernon Kinietz and E. W. Voegelin, Occasional Contributions from the Museum of Anthropology, University of Michigan, no. 9 (Ann Arbor: University of Michigan Press, 1939), 1-8. 
from one of these two dominant divisions. The Peckuwe maintained order and oversaw the celebration of religious matters. The Maykujay, on the other hand, had charge of food, health, and medicine for the nation. Lastly, the Kispokotha's realm of responsibility included warfare and the training of warriors. ${ }^{97}$ Considering that the various septs often lived hundreds of miles apart, the system of having discreet spheres of control as described by Alford may have been more of a theoretical ideal than a political reality. Some anthropologists theorize that Iroquois attacks into the Ohio Valley during the mid-seventeenth century may have disrupted the Shawnees before the various septs had forged a stronger tribal identity. If this be the case, the largely autonomous septs may represent an earlier stage of Algonquin political and social evolutionary development. ${ }^{98}$

The civil leadership of each Shawnee sept consisted of a principal chief along with an informal body of elderly men who acted as councilors. Chiefs typically held their position for life provided they possessed competency and good character. Upon the death of a chief, one of his sons inherited the position. Being the firstborn did not necessarily guarantee a chieftainship because the elders did not consider birth order when selecting a new leader among a group of siblings. In cases where a deceased chief lacked a worthy male heir, the elders appointed an unrelated man as the new chief. A parallel system of lesser chiefs and councilors served within the numerous villages to provide civil leadership on the local level. ${ }^{99}$

Shawnee women enjoyed much closer equality with Shawnee men than their counterparts

\footnotetext{
${ }^{97}$ Thomas Wildcat Alford, Civilization: As Told To Florence Drake (Norman: University of Oklahoma Press, 1936), 44.

${ }^{98}$ Clark, Shawnee, 33.

${ }^{99}$ Trowbridge, Shawnese Traditions, 11.
} 
in European society. This egalitarianism extended even into the political realm. Wives, mothers, and sisters of male village chiefs often served as "peace women" whose responsibilities included the oversight of domestic activities, such as planting crops and preparing feasts, as well as advising male chiefs and counselors. Rarely, female chiefs sat as full members on the council of elders or even served as interim village chiefs while the elders selected who would succeed a deceased male leader. Although women exerted as much power in tribal politics as men, their power tended to revolve more around informal advising and influencing than it did holding formal positions of leadership. Additionally, Shawnee women had the sometimes difficult task of trying to persuade a "renegade" warrior to "lay down the hatchet" if he seemed intent on pursuing warfare contrary to the wishes of the village. ${ }^{100}$

The Shawnees augmented the leadership of village chiefs with a system of war chiefs whose primary responsibilities involved defending their villages from attack, launching attacks against enemies, and advising the village chiefs on matters relating to land cessions and international affairs. Unlike the largely hereditary position of being a village chief, a Shawnee man who wished to become a war chief had to earn that distinction on the field of battle. Three requirements had to be fulfilled by the prospective war chief. First, he must have personally led at least four raids into the territory of his adversary. Second, on each of these raids, at least one scalp must have been taken. And third, all of the warrior's followers must have returned to their village unharmed. Upon the fulfillment of these perquisites, a feast would be held to celebrate the warrior's achievements and to formally recognize him as a war chief. ${ }^{101}$ Thus, only by

\footnotetext{
${ }^{100}$ Trowbridge, Shawnese Traditions, 12-23; Clark, Shawnee, 36.

${ }^{101}$ Trowbridge, Shawnese Traditions, 12; Howard, Shawnee!, 108.
} 
successfully attacking his enemies and taking scalps could a Shawnee man gain the qualifications needed to become a war chief.

Within Shawnee society there existed a well-defined division of labor based upon one's sex. Children grew to adulthood with a clear understanding of their future role in family and village life. Shawnee men focused their labor activities on hunting, trapping, fishing, and warfare while women attended to domestic matters, such as farming, child rearing, tanning leather, wigwam construction, and cooking. Such a pronounced division of labor existed because hunting and warfare often removed men from a village for months at a time. With the men frequently gone, virtually all domestic duties fell to the women. Occasionally, men helped with the more physically demanding chores such as clearing a new garden plot in the forest, however, once the ground had been prepared for planting, his involvement with agriculture typically ended. Although the different sexes labored at very different tasks, together, they provided effectively for the needs of their village and families. ${ }^{102}$

The Shawnees derived their livelihoods through a combination of hunting, fishing, gathering, farming, and trading. The men hunted a variety of game animals including deer, elk, bear, raccoons, turkeys, and to a lesser extent, beavers, squirrels, and other small game animals. ${ }^{103}$ By far, the white-tailed deer comprised the single most important source of animal protein for the Shawnees. Archeologists studying bone fragments from the site of a seventeenth century village

${ }^{102}$ James Axtell, ed., The Indian Peoples of Eastern America: A Documentary History of the Sexes (New York: Oxford University Press, 1981), 103-4.

${ }^{103}$ James B. Griffin, "Late Prehistory of the Ohio Valley," in Northeast, vol. 15 Handbook of North American Indians, ed. Bruce G. Trigger (Washington, D.C.: Smithsonian Institution, 1978), 552. 
in present Putnam County estimated that 89 percent of the inhabitants' meat came from deer. The researchers further determined that for every one hundred deer killed; these villagers had harvested only thirteen raccoons, eight squirrels, four turkeys, and two beavers. An absence of buffalo remains at the village may indicate that the men either did not hunt buffalo or they butchered the huge carcasses at the kill site. ${ }^{104}$

Beyond hunting, Shawnee men also contributed to the subsistence of their families by fishing and gathering fresh water clams. Unlike hunting which occurred year round, fishing tended to coincide with the spring spawning runs. ${ }^{105}$ The men used several different methods of fishing including angling with bird claw fishhooks and bone gorges, netting, spearing by torchlight, shooting with bow and arrows, and wicker traps. ${ }^{106}$

The Shawnees added seasonal variety to their diet by gathering wild plant foods from the forest. As a general rule, they consumed wild fruits and berries fresh, though on occasion, they dried some for future use. ${ }^{107}$ They also stored chestnuts, hickory nuts, and acorns for later use as well. ${ }^{108}$ In the late winter, the Shawnees produced sugar by tapping maple trees and boiling down the sap over a slow fire. A single tree could yield up to seven pounds of sugar each spring. Like

${ }^{104}$ John E. Guilday, Biological and Archeological Analysis of Bones from a 17th Century Indian Village (46 PU 31), Putnam County, West Virginia (Morgantown: West Virginia Geological and Economic Survey, 1971), 7, 21-22, 34.

${ }^{105}$ Guilday, Biological and Archeological Analysis, 40.

${ }^{106}$ Clark, Shawnee!, 40; Paul A. W. Wallace, Indians in Pennsylvania (Harrisburg: Pennsylvania Historical and Museum Commission, 1993), 37.

${ }^{107}$ Alford, Civilization, 41.

${ }^{108}$ Alvin M. Josephy, Jr., America in 1492: The World of the Indian Peoples before the Arrival of Columbus (New York: Alfred A. Knopf, 1993), 128. 
other forms of gathering, women and children did most of the sugaring, though men sometimes helped if the winter hunt had been completed. ${ }^{109}$ In light of the fact that honeybees had just recently been introduced to North America from the Old World, the Shawnees used maple sugar as their traditional source of sweetener. ${ }^{110}$

The Shawnees practiced slash and burn agriculture in much the same fashion as other Eastern Woodland Indians. Originally, they had used stone hatchets to clear underbrush and to girdle trees growing within their prospective fields. Later, the acquisition of iron tools from European traders made the work considerably easier. Considering that one acre of old growth forest in western Virginia contained an average of twenty-six trees with trunk diameters over eighteen inches, it is of little surprise that iron axes quickly became a popular trade item. ${ }^{111}$ After the cut wood had dried, the Shawnees piled it around the girdled trunks of the larger trees and set it all ablaze. Women gradually grubbed out the smaller stumps leaving the larger stumps and trunks in place. In all, it often required several years to prepare a new field for planting. ${ }^{112}$

The Shawnees raised their crops in small hills rather than rows. Using hoes fashioned from the shoulder blades of deer, women farmers scraped the topsoil into mounds that measured

${ }^{109}$ David Zeisberger, David Zeisberger's History of the Northern American Indians, ed. Archer Butler Hulbert and William Nathaniel Schwarze (Columbus: Ohio State Archaeological and Historical Society, 1910), 48-51.

${ }^{110}$ Alfred W. Crosby, Ecological Imperialism: The Biological Expansion of Europe, 9001900 (Cambridge: Cambridge University Press, 1986), 188-89.

${ }^{111}$ Stanley W. Baker, “An Iron Trade Axe from the Neale's Landing Site, 46WD39, on Blennerhassett Island," West Virginia Archeologist 36 (Fall 1988); Guilday, Biological and Archeological Analysis, 4.

${ }^{112}$ Bruce G. Trigger, The Huron: Farmers of the North, 2d ed. (Fort Worth: Harcourt Brace Jovanovich College Publishers, 1990), 31. 
about thirty inches in diameter with an additional thirty-inch space between the mounds. ${ }^{113}$ Land that had been totally cleared of all trees and stumps had space sufficient for approximately twentyfive hundred hills per acre. ${ }^{114}$ Into each hill they planted a combination of corn, beans, and squash. Whether they also raised tobacco (Nicotiana rustica) like their neighboring tribes to the north and east is unknown. ${ }^{115}$ By planting corn a few weeks prior to beans and squash, the corn stalk served as a living beanpole. ${ }^{116}$ Throughout the early summer, women periodically hoed the field to keep weeds down, although after the squash and pumpkin plants became mature, their broad flat leaves inhibited weed growth by shading the ground. Even young children contributed to the family's subsistence by guarding the field against birds and animals.

Barring drought, blight, insects, and animal pests, the villagers could expect to harvest their first ears about eighty-four days after planting. To celebrate the occasion, they held their annual Green Corn ceremony in mid-August. Two weeks later, the longer season varieties of corn ripened. ${ }^{117}$ For winter storage, the women peeled the husks back from the corncobs without breaking them off and braided them together into long strands they suspended from the interior

${ }^{113}$ Trigger, Huron, 32.

${ }^{114}$ Conrad E. Heidenreich, "Huron," in Northeast, vol. 15 Handbook of North American Indians, ed. Bruce G. Trigger (Washington, D.C.: Smithsonian Institution, 1978), 380.

${ }^{115}$ Robert F. Maslowski, "Prehistoric People of the Kanawha Valley," $<$ http://www.wvlc.wvnet.edu/wvarl/srbk.html.html>, 13 September 1997; Clark, Shawnee, 40.

${ }^{116}$ Howard, Shawnee!, 49.

${ }^{117}$ R. Douglas Hurt, Indian Agriculture in America: Prehistory to Present (Lawrence: University Press of Kansas, 1987), 31; Howard, Shawnee!, 269. 
roof of a wigwam. ${ }^{118}$ If desired, the dried kernels could later be shelled and stored in baskets or clay pots. In addition, the women preserved squash and pumpkins for up to five months by drying thinly sliced pieces. ${ }^{119}$

Calculating the Shawnees' agricultural productivity during the eighteenth century is difficult because of a scarcity of documentation on the subject. A tentative answer to this question, however, can be gained by examining the known corn yields of other agriculturalists in the region. During the late seventeenth century, a French Jesuit observed that the Hurons achieved average yields of twenty-seven bushels of corn per acre. Anthropologist Conrad Heidenreich concurred with the Jesuit's observations, but also noted that the Hurons' yields sometimes dropped to as low as seven to ten bushels per acre when the soil had become exhausted. White settlers using similar slash and burn methods also achieved harvests of between twenty to thirty bushels per acre of hills. ${ }^{120}$ Based on the above observations, it is reasonable to assume that the Shawnees achieved similar results. ${ }^{121}$

Although agriculture was important to the Shawnees, they did not depend upon it as heavily as other Eastern Woodland Indians. This becomes evident when one considers that a Shawnee family of five to eight people typically cultivated only about one acre of crops for the entire family whereas other related tribes planted one acre per person. Anthropologists who have

${ }^{118}$ Alford, Civilization, 35 .

${ }^{119}$ Trigger, Huron, 33.

${ }^{120}$ Heidenreich, "Huron," 381.

${ }^{121}$ For the sake of comparison, modern farmers using hybrid seeds and chemical fertilizers regularly achieve corn yields of one hundred bushels per acre. 
studied Shawnee agriculture conclude, "clearly corn was not a staple food in the year-round subsistence economy of the Shawnee; for half of each year, at least, it figured only minimally, if at all in their basic economy." ${ }^{122}$ Understanding that the Shawnees relied less on horticulture than many of the neighboring Indians helps to explain why American frontiersmen had such a difficult time dislodging them from the upper Ohio Valley despite having burnt their crops on an almost annual basis during the late eighteenth century. ${ }^{123}$ Although farming comprised an important part of the Shawnees' subsistence strategy, hunting may have been even more central.

Through their combination of hunting, fishing, gathering, and farming, the Shawnees provided for all of their basic needs. But like most Europeans, the Shawnees apparently desired a standard of living somewhat above mere subsistence. Consequently, the Shawnees augmented their household production by trading with neighbors for luxury items not locally available. Even prior to the arrival of Europeans, the Shawnees engaged in extensive intertribal trade over a sophisticated network of well-used trails that connected western Virginia with locations as widespread as the Atlantic and Gulf coasts, the lower Ohio Valley, and Canada. ${ }^{124}$ Based on

${ }^{122}$ Erminie Wheeler Voegelin, "The Place of Agriculture in the Subsistence Economy of the Shawnee," Papers of the Michigan Academy of Science, Arts, and Letters 26 (1940): 518-20; Clark, Shawnee, 41.

${ }^{123}$ For an overview of American efforts to dislodge the Shawnees from the upper Ohio Valley, see Randolph C. Downes, Council Fires on the Upper Ohio: A Narrative of Indian Affairs in the Upper Ohio Valley until 1795 (Pittsburgh: University of Pittsburgh Press, 1968). For a more popular, yet historically accurate account of the same topic, see James Alexander Thom, Panther in the Sky (New York: Ballantine Books, 1989).

${ }^{124}$ Timothy G. Baugh and Jonathan E. Ericson, eds., Prehistoric Exchange Systems in North America (New York: Plenum Press, 1994), 35, 41; Edward V. McMichael, Introduction to West Virginia Archeology, 2d ed., rev. (Morgantown: West Virginia Geological and Economic Survey, 1968), 51; Josephy, America in 1492, 128-29. 
artifacts discovered at archeological sites, desirable trade goods included marine shells, unusual varieties of stone, and cold-hammered copper. From these raw materials, the Shawnees fashioned jewelry items such as conch shell gorgets, green soapstone smoking pipes, and strings of beads made from tiny seashells. ${ }^{125}$

Little information exists regarding commodities that the Shawnees may have exchanged in return, though some scholars suspect that they may have traded cannel coal, a type of coal suitable for carving. ${ }^{126}$ Other researchers suggest that they may have been salt traders. During the eighteenth century, the Shawnees sometimes visited natural salt springs where they collected the briny water in clay pans and allowed it to naturally evaporate leaving behind a thin layer of salt crystals. ${ }^{127}$ In the summer of 1755 , white captive Mary Draper Ingles helped a party of Shawnees make salt in the Kanawha Valley of western Virginia. ${ }^{128}$ While some of this salt would have been needed for personal use, any surplus would have been available for barter.

The Shawnees carried out their various subsistence activities in an annual cycle based upon the seasons. Throughout the fall from late September through December, they generally lived in small temporary hunting camps scattered throughout, Ohio, Kentucky, and western Virginia. Leaving the elders, children, and some of the women behind at these camps, the men spread out over the countryside to hunt deer, bears, and other animals. Sometime around

\footnotetext{
${ }^{125}$ Ronald W. Moxley, "The Orchard Site: A Proto-Historic Fort Ancient Site in Mason County, West Virginia," West Virginia Archeologist 40 (Spring 1988): 35, 38-40.

${ }^{126}$ Baugh, Prehistoric Exchange Systems, 232.

${ }^{127}$ Clark, Shawnee, 32, 41.

${ }^{128}$ John P. Hale, Trans-Allegheny Pioneers, 3d ed. (Radford, Va.: Roberta Ingles Steele, 1971), 38.
} 
January, the men shifted their attention away from deer hunting in favor of trapping furbearers such as beavers. Trapping typically continued till late February when the hunting camps broke up and everyone returned to their towns located mostly in eastern and central Ohio. Springtime activities included maple sugaring and preparing fields for planting. Throughout the summer, the women tended their crops while the men hunted or waged war against enemies near and far. By the end of harvest in September, the Shawnees again divided into small extended family groups and moved to their winter quarters to start the cycle anew. ${ }^{129}$

As Euro-American families moved into the forests of western Virginia, the Shawnees found it increasingly difficult to practice their seasonal movements. According to a Shawnee diplomat, the problem with settlers was two-fold. First, he complained of "the woods [being] covered with White people."130 By this, he implied that the mere physical presence of settlers disrupted his peoples' way of life. How could they move to their winter camps if settlers occupied their hunting grounds? Chiksika, brother of Tecumseh, eloquently expressed the frustration felt by many Shawnees when he proclaimed, "The whole white race is a monster who is always hungry and what he eats is land."131

The diplomat also complained that the young men were "disappointed in their hunting."132

${ }^{129}$ Clark, Shawnee, 38-41; Charles Callender, "Shawnee." in Northeast, vol. 15 of Handbook of North American Indians, ed. Bruce G. Trigger (Washington: Smithsonian Institution, 1978), 624; Roy Bird Cook, Washington's Western Lands (Strasburg, Va.: Shenandoah Publishing House, 1930), 33.

${ }^{130}$ Doc. His. N.Y., 8:462.

${ }^{131}$ Chiksika quoted in Allan W. Eckert, A Sorrow in Our Heart: The Life of Tecumseh (New York: Bantam Books, 1992), iv.

${ }^{132}$ Doc. His. N.Y., 8:462. 
As increasing numbers of pioneer families arrived in western Virginia, the Shawnees faced escalating competition for the finite game resources. Undoubtedly, the wasteful hunting practices of many settlers aggravated the situation. Consider William Haymond, Jr., of Harrison County who admitted that whenever he saw a deer, he simply could "not resist the temptation to shoot it." ${ }^{\prime 13}$ Further evidence of this attitude is reflected in the journal of explorer Christopher Gist who reported killing a dozen turkeys in a single day. ${ }^{134}$ Apparently, Euro-American settlers learned wasteful hunting practices early. Following the Revolutionary War, traveler Johann David Schoepf reported that two boys near Wheeling had killed 219 squirrels over a three-day period. ${ }^{135}$ After a generation of such wanton hunting practices, settler Joseph Doddridge lamented "the buffalo and elk have entirely disappeared from this section of the country. Of the bear and deer but very few remain.... The wild turkeys, which used to be so abundant ... are now rarely seen." ${ }^{136}$

The Shawnees realized that if they did nothing to stem the flow of settlers into western Virginia and the upper Ohio Valley, they stood to lose not only tribal land, but also their very way of life. After all, they depended upon the deer, fish, wild plants, and farmland of the region to achieve their basic subsistence. Unfortunately, Euro-American settlers coveted these very same

${ }^{133}$ William Haymond, Jr., to Luther Haymond, 13 April 1842, William Haymond, Jr. Papers, WVRHC.

${ }^{134}$ William M. Darlington, Christopher Gist's Journals with Historical, Geographical, and Ethnological Notes and Biographies of His Contemporaries (Pittsburgh: J. R. Weldin, 1893), 35.

${ }^{135}$ Johann David Schoepf, Travels in the Confederation, 1783-1784 vol. 1, ed. Alfred J. Morrison (New York: Burt Franklin, 1986), 295.

${ }^{136}$ Joseph Doddridge, Notes on the Settlement and Indian Wars (1912: reprint, Parsons, W. Va.: McClain, 1976), 57, 59. 
resources. Herein lies the fundamental cause of the western Virginia Indian wars: the Shawnees and settlers both relied on the same resources to achieve their livelihoods. As competition for these finite resources escalated throughout the second half of the eighteenth century, the Shawnees realized that any failure on their part to retain access to the land could very well result in destitution.

From a strategic perspective, one of the most ideal times for the Shawnees, and other Appalachian Indians, to strike out against settlers occurred during those periods when Europeans waged war against one other, namely the French and Indian War and the Revolutionary War. During these two periods, not only did Europeans court and indulge Indian allies, but they also provided them with guns, munitions, and supplies. Although some scholars have characterized the Indians as being pawns, puppets, or proxies of the Europeans in these wars for empire, and in the Indians' conflicts against one other, this “imperialist" interpretation smacks of Eurocentrism. ${ }^{137}$ Historian Richard White suggests a much more plausible interpretation when he uses the phrase "parallel war" to describe Indian involvement in these European wars. ${ }^{138}$ In other words, the Shawnees did not join with the French or the English out of a sense of loyalty or economic dependency. Rather, they formed temporary alliances with Europeans because they shared a common foe. In 1758, an "old Indian on the Ohio" named Ackowanothio explained the

${ }^{137}$ For an example of this Euro-centric perspective, see Wilma Dunaway, The First American Frontier: Transition to Capitalism in Southern Appalachia, 1700-1860 (Chapel Hill: University of North Carolina Press, 1996), 28-29.

${ }^{138}$ Richard White, The Middle Ground: Indians, Empires, and Republics in the Great Lakes Region, 1650-1815 (Cambridge: Cambridge University press, 1991), 240, 244; Ian K. Steele, Warpaths: Invasions of North America (New York: Oxford University Press, 1994), 17576. 
Ohio tribes' perspective to the English. In words that sound strangely Jeffersonian, the elderly Indian stated

You wonder at our joining with the French in this present War. Why can't you get sober and once think Impartially? Does not the law of Nations permit, or rather Command us all, to stand upon our guard, in order to preserve our lives, the lives of our Wives and Children, our Property and Liberty? ${ }^{139}$

At least some Indians fought out of personal interest, not because a distant puppet master had raised their hatchets with the pull of a string.

Despite receiving military aid from their European allies, the Shawnees suffered hundreds of casualties in their struggle against settlers and soldiers in the trans-Allegheny region. These wartime losses, in addition to continuing deaths from periodic outbreaks of smallpox and measles, caused the Shawnees' population to plummet. Calculating Indian populations during the colonial period is challenging at best, but based on archeological evidence and seventeenth-century historical records, it appears that the Shawnees may have had a substantial population in comparison with their neighbors. In 1673, for example, Father Marquette while descending the Mississippi River wrote upon reaching the mouth of the Ohio that "This river flows from the lands of the East, where dwell the people called Chaouanons [Shawnees] in so great numbers that in one district there are as many as 23 villages, and 15 in another, quite near one another."140 Anthropologist James Howard estimated that ten to twelve thousand Shawnees might have inhabited the Ohio Valley during the mid-seventeenth century before being disrupted by Iroquois attacks, disease, and forced migrations. By 1775, that number had fallen to about three thousand

${ }^{139}$ Penn. Archives, 3:548.

${ }^{140}$ Jacques Marquette, "Of the first Voyage made by Father Marquette toward New Mexico, and How the idea thereof was Conceived," in JR 59:145. 
Shawnees. ${ }^{141}$ If one accepts that the population declined from between 10,000 and 12,000 people to about 3,000 , then it can be calculated that their population experienced a reduction of somewhere between 70 and 75 percent over a 125 year period. This range is in line with the generally accepted estimate that introduced diseases, such as measles and small pox, caused mortality rates as high as 75 to 90 percent within some tribes. ${ }^{142}$

In an effort to stem this population decline, the Shawnee, Iroquois, and Delaware Indians of the upper Ohio Valley widely adopted captives into families that had experienced losses. The ethnicity of a potential adoptee does not appear to have figured very heavily in the selection process. Thus, there are many documented instances of Indians adopting members of another tribe, captured African slaves, or even Euro-American colonists. Although the Indians tended to adopt more women and children than adult males, there are numerous instances of white adult men being adopted into Indian families. In July 1774, for example, a war party under the leadership of the Mingo chief Logan captured settler William Robinson near present Clarksburg, West Virginia and escorted him back to their village in present Ohio. Upon his arrival, a debate ensued whether he should be adopted or burnt alive at the stake. Fortunately for him, those in favor of adoption prevailed. According to Robinson, they tied a belt of wampum around him as "the mark of adoption." Shortly, he found himself living in "the cabin of an old squaw" who he later understood to be his "aunt." Likewise, he soon meet his two Indian "brothers." Eventually, Robinson realized "that he now stood in the place of a warrior" of that family. In Robinson's

${ }^{141}$ Howard, Shawnee!, 31-32.

${ }^{142}$ See Colin G. Calloway, New Worlds for All: Indians, Europeans, and the Remaking of Early America (Baltimore: Johns Hopkins University Press, 1997), 33-41. 
case, not only did he replace a specific individual who had died, but he also "inherited" that person's kinship ties. ${ }^{143}$

Although Robinson did not dwell on the details of his adoption into the tribe, other captives have described a sometimes elaborate initiation ceremony. One of the most ubiquitous elements of Indian captivity and adoption narratives is the "running of the gauntlet." The gauntlet typically consisted of two parallel lines of villagers who stood facing one another with just enough space between the lines for a prisoner to run. The length of any particular gauntlet varied according to the size of the village, but could at times be several hundred yards long. At the end of the gauntlet might be a council house, a Shawnee chief, or some other objective. As the oftentimes naked captive ran the gauntlet, the villagers struck him with fists, clubs, switches, and briars. ${ }^{144}$ One runner described being struck across the head with the flat of a sword while another captive reported having sand thrown in his eyes as he ran a gauntlet near Fort Duquesne in $1755 .{ }^{145}$ Captive women and children often received a much lighter thrashing than adult men with some children even avoiding the gauntlet altogether. ${ }^{146}$ At other times, children ran an

\footnotetext{
${ }^{143}$ William Robinson, "The Declaration of William Robinson" in Thomas Jefferson, Notes on the State of Virginia, ed. William Pedan (New York: W. W. Norton \& Company, 1954), 24243.

${ }^{144}$ For a detailed firsthand account of a captive running the gauntlet, see O. M. Spencer, The Indian Captivity of O. M. Spencer, ed. Milo M. Quaife (1838; reprint, Chicago: R. R. Donnelly, 1917), 72-74.
}

${ }^{145}$ James Smith "Prisoner of the Caughnawagas" in Captured by the Indians: 15 Firsthand Accounts, 1750-1870, ed. Frederick Drimmer (New York: Dover Publications, 1961), 28; Beverly W. Bond, Jr., "The Captivity of Charles Stuart, 1755-57," The Mississippi Valley Historical Review 13 (June 1926), 66.

${ }^{146}$ George Henry Loskiel, History of the Mission of the United Brethren among the Indians in North America (London: Printed for the Brethren's Society for the Furtherance of the 
alternate style of gauntlet whereby the youngster had to outpace Indian children armed with switches. ${ }^{147}$ Regardless of the configuration of a gauntlet, the beating of a captive not only allowed the Indians to vent their anger against an enemy, but it also had the symbolic value of thrashing the "whiteness" out of a prospective adoptee. ${ }^{148}$

A second element of the adoption process involved the ceremonial bathing of a captive. The experience of eighteen year old James Smith appears to have been typical of those adopted by the Ohio Valley Indians. Smith described how three young Indian women led him waist deep into a river where they "plunged me under water and washed and rubbed me severely."149 Following his Indian "baptism," a chief explained through an interpreter that "by the ceremony which was performed this day, every drop of white blood was washed out of your veins." 150

The Indians completed the transformation of their captive by dressing and adorning him or her in the fashion of an Indian. Once again, James Smith exemplifies this procedure. First, his captors plucked all of the hair from his head save for a topknot that they decorated with narrow beaded garters, braids, and silver brooches. Afterwards, they "bored" his nose and ears decorating them with "earrings and nose jewels." They then dressed him in a new ruffled shirt, leggings, a pair of moccasins, a tinsel-laced cloak, and leg garters embellished with beads,

Gospel, 1794), 1:149; Spencer, Indian Captivity, 72-74.

${ }^{147}$ Henry Clay Alder, A History of Jonathan Alder: His Captivity and Life with the Indians (Akron, Ohio: University of Akron Press, 2002), 42-44.

${ }^{148}$ James Axtell, The Invasion Within: The Contest of Cultures in Colonial North America (New York: Oxford University Press, 1985), 312-14.

${ }^{149}$ Smith, "Prisoner of the Caughnawagas," 32.

${ }^{150}$ Smith, "Prisoner of the Caughnawagas," 32. 
porcupine quills, and red hair. Face paint and a clump of red-dyed feathers attached to his topknot completed the physical transformation of James Smith. ${ }^{151}$ The change in appearance could be quite striking. ${ }^{152}$

Adoption into a tribe conferred all of the rights, privileges, and obligations that came with being an Indian. An Ohio Iroquois chief informed James Smith "My son, you have nothing to fear. We are under the same obligation to love, support and defend you that we are to love and defend one another. You are to consider yourself as one of our people." ${ }^{, 153}$ A Wyandot chief similarly explained that anyone adopted into his tribe is not a slave. They have "free liberty to go anywhere, or act as they please" as it is not "our Custom to Exercise any Authority over them, they having the same privileges with ourselves." ${ }^{\text {54 }}$ Thomas Ridout, captured by the Shawnees in 1788, enjoyed "perfect liberty" by his third night after being captured. ${ }^{155}$ Some European adoptees, particularly children, ultimately assimilated so fully into Indian society that they resisted being "rescued" by colonial soldiers. ${ }^{156}$

Although adopting captives served the pragmatic purpose of providing that family with the physical labor of the adoptee, captives also helped to sustain the spiritual power of the family.

${ }^{151}$ Smith, "Prisoner of the Caughnawagas," 31-32.

${ }^{152}$ See Peter Kalm, Peter Kalm's Travels in North America: The English Version of 1770, ed. Adolph B. Benson (New York: Dover Publications, 1966), 2:457.

${ }^{153}$ Smith, "Prisoner of the Caughnawagas," 32.

${ }^{154}$ William Johnson, The Papers of Sir William Johnson (New York: University of the State of New York Division of Archives and History, 1921), 3:486.

${ }^{155}$ Matilda Edgar, Ten Years of Upper Canada in Peace and War, 1805-1815; Being The Ridout Letters (Toronto: William Briggs, 1890), 352. 
The Indians believed that the untimely death of a relative through violence or disease left that family with a net loss of spiritual power. By adopting an outsider into their midst, the family could regain that lost power. To accomplish this, the Shawnees had to transform the spiritual identity of their captive from being an enemy to that of a friend and family member. To evoke this spiritual change, they merely had to apply the proper ceremonies. Thus, when the Shawnees thrashed a captive at the gauntlet, "baptized" him at a river, dressed him as an Indian, and bestowed upon him an Indian name, they were actually trying to transform that captive's spirit through a ceremonial adoption process. If successful, the family, and village, regained the lost spiritual power. ${ }^{157}$

Unfortunately for captives, the Shawnees had other means of gaining their spiritual power. If a prisoner appeared unsuitable for adoption, he instead might be subjected to ritual torture and perhaps even cannibalism. Cannibalism among the Shawnees appears to have been on the decline throughout the eighteenth century; however, it still had its practitioners at the time of EuroAmerican settlement in western Virginia. Within some villages there existed a cannibalistic society led by four elderly women. According to Tenskwatawa, the brother of Tecumseh, whenever villagers heard the "prisoners yell" of a returning war party, the cannibal women and female "peace chiefs" both set out to meet the returning warriors in hopes of being the first to physically touch the prisoners. If a peace woman reached a captive first, his or her life would be spared. But if a cannibal arrived first, she said to the warriors "Thank you my children you bring

${ }^{156}$ Axtell, Invasion Within, 309.

${ }^{157}$ Daniel K. Richter, The Ordeal of the Longhouse: The Peoples of the Iroquois League in the Era of European Colonization (Chapel Hill: University of North Carolina Press, 1992), 3233. 
me good Broth." The prisoner was then tortured to death at the stake, cooked, and eaten. According to Chief Black Hoof, members of the cannibalistic society used the skulls of former victims as bowls and prided themselves on their ability to inflict great pain when tormenting their captives. $^{158}$

Beyond gaining the spiritual power of a victim through ceremonial torture and cannibalism, the Shawnees also tortured captives if one of their chiefs died in battle. ${ }^{159}$ Although they did this partly out of a desire for vengeance, there may also have been a ceremonial element behind the practice. Unlike Europeans who generally looked upon the death of a soldier in battle as being honorable, the Indians believed that the spirit of a slain warrior roamed the earth rather than ascended into the heavens. ${ }^{160}$ Through the ceremonial torture and death of a prisoner, the Shawnees may have been releasing the spirits of their warriors by providing a substitute spirit to haunt the earth. The white captive Thomas Ridout described how after torturing a captive to death, the Shawnees "fired their guns, and with large twigs beat their wigwams on the tops and sides, shouting" to drive away the spirit of their victim. ${ }^{161}$ Apparently, the killing of a prisoner at the stake doomed the victim's spirit to roam the earth much like that of a slain warrior. Whether the Shawnees intended for the prisoner's spirit to serve as a substitute for that of the fallen warrior is unclear.

Regardless, for those who fell victim to Indian torture, the belief system that underlay the

${ }^{158}$ Trowbridge, Shawnese Traditions, 53-54, 64.

${ }^{159}$ Trowbridge, Shawnese Traditions, 21.

${ }^{160}$ Richter, Ordeal of the Longhouse, 38.

${ }^{161}$ Edgar, Ten Years of Upper Canada, 364. 
practice was irrelevant. Detailed accounts of the horrors of torture are a mainstay of frontier narratives and captivity tales. Ridout, for example, related how the Shawnees painted the face of a fellow captive black to signify that he would be killed rather than adopted. When the time came, the Indians cut off the man's ears then released him into the forest where they proceeded to chase him down and recapture him. The captive then endured three hours of torment at the stake before succumbing to death. ${ }^{162}$

Europeans condemned the Indians' practice of torturing captives and presented it as evidence of their alleged barbarity. The Reverend Claude Godfrey Cocquard, for example, disdainfully wrote that the Indians "kill all they meet, men, women, and children. Every day they have some in their kettle, and after having abused the women and maidens, they slaughter or burn them." ${ }^{\text {163 }}$ Although raiding, taking captives, and torturing prisoners indeed involved brutality, it is imperative that we not judge the Shawnees outside of the historical and cultural context in which these actions occurred. Throughout the entire frontier period of western Virginia history from the 1670s through the mid-1790s, the Shawnees found themselves in a prolonged fight for their very survival. In the process, they committed no act of brutality any worse than those inflicted upon them by Europeans. After all, it is common knowledge that Europeans scalped Indians, fashioned leather from their skin, ambushed them, killed their women and children, kidnapped them, burnt their homes and crops, sold them into slavery, and intentionally infected their villages with the smallpox virus. In short, the eighteenth century was a brutal period for everyone associated with the western Virginia backcountry.

\footnotetext{
${ }^{162}$ Edgar, Ten Years of Upper Canada, 363-34.

${ }^{163}$ Doc. His. N.Y., 10:528.
} 
Is it fair then to bestow the epithet "warlike" upon the Shawnees? The answer to this question must be an unequivocal "no," it is neither fair nor accurate to characterize the Shawnee people as being inherently warlike. As anthropologist James Howard points out, "war is a cultural and historical phenomenon, not a matter of genetics or individual psychology." ${ }^{\text {164 }}$ Prior to the Shawnees coming into direct contact with Europeans, Father Marquette in 1673 wrote that "they are not at all warlike" and "cannot defend themselves" being "Like flocks of sheep."165 Only after settlers encroached upon the Shawnees' land did colonists begin to conceptualize them as being a "warlike people."

${ }^{164}$ Howard, Shawnee!, 128.

${ }^{165}$ Jacques Marquette, "Of the first Voyage made by Father Marquette toward New Mexico, and How the idea thereof was Conceived," in JR 59:145. 


\section{Chapter Four}

Settling the Western Virginia Backcountry

When the first Euro-American settlers crossed the Allegheny Mountains into western Virginia during the mid-eighteenth century, they entered a realm that had already seen human occupation for millennia. ${ }^{166}$ The very landscape itself bore testimony to this occupation in the form of scattered Native American villages, burial mounds, an elaborate network of trails, hunting camps, and manmade clearings in the forest. Although Old World diseases, intertribal warfare, and forced migrations had dramatically reduced the native population of the region, the forests of western Virginia still contained a resident population of Indians including the native Shawnees, Iroquoian speaking "Mingos," and small numbers of recently arrived Delawares. ${ }^{167}$ In addition to these permanent inhabitants, parties of non-resident Cherokees, Wyandots, Ottawas, Miamis, and Iroquois occasionally passed through the region while conducting trade, diplomacy, and warfare.

The presence of these diverse Indian groups not only prolonged the frontier experience of the men

${ }^{166}$ Many different cultural groups of Indians have lived and hunted in present West Virginia for the past 12,500 years. Otis K. Rice and Stephen W. Brown West Virginia: A History, 2d ed. Lexington: University Press of Kentucky, 1993), 3.

${ }^{167}$ Daniel B. Fowler, “An Old Shawnee Town in West Virginia,” West Virginia Archeologist 28 (Spring \& Fall 1979): 24-29; Ronald W. Moxley, "The Orchard Site: A ProtoHistoric Fort Ancient Village Site in Mason County, West Virginia," West Virginia Archeologist 40 (Spring 1988): 32-41; Douglas H. Ubelaker, "Human Skeletal Remains from the Thorn Mounds (46MG78 and 46MG79)," West Virginia Archeologist 38 (Fall 1986): 53-54; Berle R. Clay and Charles M. Niquette, "Middle Woodland Mortuary Rituals in the Gallipolis Locks and Dam Vicinity, Mason County, West Virginia," West Virginia Archeologist 44 (Spring \& Fall 1992): 1-25; Edward V. McMichael, Introduction to West Virginia Archeology, $2^{\text {nd }}$ ed. rev. (Morgantown: West Virginia Geological and Economic Survey, 1968); Alexander Scott Withers, Chronicles of Border Warfare (1895; reprint, Parsons, W. Va.: McClain, 1989), 75, 136. 
and women who settled in western Virginia during the second half of the eighteenth century, but they also indirectly led to greater cultural diversity within the pioneer population.

In exploring the relationship between Indian warfare and the settlement of western Virginia, we first turn our attention to the pioneers themselves and the critical question of whether the cultural background of the pioneers determined how they and the Indians related with one another. After all, if the Indians responded differently to different categories of people, then the dynamic, or driving force, in the frontier history of the region might better be explained by cultural and political factors rather than Indian-related violence and warfare. In the process of addressing this important issue, a second equally important question arises. Just how much diversity existed among the pioneers anyway?

According to the dictionary the word "pioneers" refers collectively to the group of people to first settle a given territory. ${ }^{168}$ Unfortunately, thinking of the pioneers as a corporate whole creates a distorted image of them by connoting a sense of unity and homogeneity that simply did not exist on the western Virginia frontier. Consider briefly the archetypal Appalachian pioneer of popular imagination. In terms of ethnicity, he is usually Scots-Irish with ancestors hailing from the plantations of Ulster. He is comparatively poor in terms of both wealth and education. He exhibits an exaggerated, yet celebrated, degree of independence and self-sufficiency due to the alleged isolation of his homestead. His personal conduct is marked by a curious duality whereby he is a God-fearing Christian on the Sabbath yet equally devoted to corn whiskey, practical jokes, and an "unrefined lifestyle" the remaining six days of the week. And lastly, the stereotypical Appalachian pioneer looked upon the Indians with an overt sense of antipathy and disdain, if not

\footnotetext{
${ }^{168}$ Webster's Ninth New Collegiate Dictionary, s. v. "pioneer."
} 
outright hatred. ${ }^{169}$

Although such a view of the frontiersmen appeals to our romanticized sense of nostalgia, the idea of Appalachian pioneer homogeneity is simply inaccurate. Rather than encompassing only a narrow collection of cultural and personality traits, those men and women who settled in trans-Allegheny Virginia during the second half of the eighteenth century displayed many of the traits associated with a heterogeneous population. Hallmarks of this Appalachian diversity included racial, ethnic, and religious plurality, socioeconomic stratification, and a wide range of attitudes in how they viewed and related to the Native Americans. In order to appreciate the heterogeneity of the pioneer population, it is necessary to step away from the overly simplistic archetypal perspective and instead focus on the actual individual pioneers themselves. Unfortunately, the limited available documentation on the earliest settlers precludes conducting any sort of statistical analysis of their cultural, racial, and socioeconomic attributes. Instead, a series of brief anecdotal sketches combined with a single more lengthy narrative will suffice to illustrate the point that ethnic and social diversity characterized the earliest pioneers to arrive on the western Virginia frontier.

The first pioneer sketch we turn to is a man by the name of Stephen Sewel. According to most traditional accounts, he along with partner Jacob Marlin made the very first Euro-American settlement in western Virginia in 1749 when the two built a cabin near the mouth of Knapps Creek at the present site of Marlinton in Pocahontas County. Settlers of English descent from the Shenandoah Valley of Virginia, the two men lived together for a short while until a religious

${ }^{169}$ James G. Leyburn, The Scotch-Irish: A Social History (Chapel Hill: University of North Carolina Press, 1962), 256-57; John Anthony Caruso, The Appalachian Frontier: America's First Surge Westward (Indianapolis: Bobbs-Merrill, 1959), 207. 
dispute prompted Sewel to vacate their cabin and move into a nearby hollow tree. ${ }^{170}$ Some traditions specify that their disagreement involved the rite of baptism and how it should be performed. ${ }^{171}$ Regardless, there is near universal agreement that Sewel possessed deep religious convictions. ${ }^{172}$

At some point prior to 1752, Sewel became involved with the Reverend George Samuel Klug, a German-born Lutheran minister who had been recruited in Europe by the Reverend John Casper Stoever, Sr., to help plant new Lutheran churches in backcountry Virginia. Stoever, who remained in Europe, proved highly successful at soliciting funds and support for the Lutherans in Virginia, however, his death prevented him from seeing his labors come to fruition. Fortunately for the Lutherans, the recently ordained Klug took up Stoever's cause and proved instrumental in establishing a formal Lutheran presence in the Shenandoah Valley during the 1740 s. $^{173}$ By the early 1750s, Klug had developed an interest in obtaining land and planting settlers in transAllegheny Virginia. Whether this stemmed from a desire to spread Lutheranism to "West

${ }^{170}$ John Stuart, "Memorandum, 1798, July 15"th ," in Ruth Woods Dayton, Greenbrier Pioneers and Their Homes (Charleston, W. Va.: West Virginia Publishing, 1942), 367; G. D. McNeill, Tales of Pocahontas County (Parsons, W. Va.: McClain, 1991), 1-3. The Stuart Memorandum also mentions "a man of unsound mind" who had wandered across the mountains from Frederick County into western Virginia where he encountered the Greenbrier River. Although he arrived about the same time as Sewel and Marlin, he did not remain as a settler.

${ }^{171}$ William T. Price, Historical Sketches of Pocahontas County, West Virginia (1901; reprint, Bowie, Md.: Heritage Books, 1990), 106.

${ }^{172}$ The contemporaneous Great Awakening then raging in Virginia may have influenced Sewel's religious faith.

${ }^{173}$ Leonard R. Riforgiato, Missionary of Moderation: Henry Melchior Muhlenberg and the Lutheran Church in English America (Lewisburg, Penn.: Bucknell University Press, 1980), 57. 
Virginia" or make money in land speculation is unclear. Regardless, to obtain land, he along with seventeen partners, including Sewel, petitioned the government of Virginia for a land grant. In November 1752, the Executive Council of Virginia responded to their request by granting them up to thirty thousand acres of land at an unspecified location in the upper Monongahela Valley. They had four years to locate, survey, and settle the land with pioneer families. ${ }^{174}$ Unfortunately for Klug and his associates, the outbreak of the French and Indian War in the summer of 1754 made it virtually impossible for them to meet the government's time requirement. Consequently, the Lutherans lost their land grant at the end of four years.

Although there are a few instances of religious groups settling in western Virginia in hopes of creating a heavenly community, this was not typical. ${ }^{175}$ Rather, most settlers moved to the frontier for the more earthly purpose of obtaining farmland. While some settlers legally purchased their farms from large speculative interests such as the Greenbrier Land Company, others "squatted" on their land with neither deed nor survey nor legal right to the land they occupied. Because of this, many of the first settlers in western Virginia are simply undocumented. Where documentation does exist, it is often anecdotal in nature. For example, George Washington

${ }^{174}$ Wilmer L. Hall, ed., Executive Journals of the Council of Colonial Virginia, vol. 5 (Richmond: Virginia State Library, 1945), 409.

${ }^{175}$ In 1789, a Seventh Day Baptist congregation from Shrewsbury, New Jersey sold their church and moved to the western Virginia frontier. They first settled along White Day Creek in present Monongalia County, however, in the spring of 1792 they moved on establishing two separate congregations at present Salem and Hepzibah in Harrison County. Prior to building a meetinghouse, the Salem congregation built a blockhouse to provide protection against Indian attacks. Corliss Fitz Randolph, A History of Seventh Day Baptists in West Virginia (Plainfield, N.J.: American Sabbath Tract Society, 1905), 29-31, 83, 104; Dorothy Davis, History of Harrison County West Virginia (Parsons, W. Va.: McClain, 1970), 575, 577. 
remarked in 1753 that some families had settled in the upper reaches of the Kanawha Valley. ${ }^{176}$ Another example would be the account of Robert Files and David Tygart who settled with their families in present Randolph County not far from the Seneca Trail. ${ }^{177}$

For some Virginians, the frontier provided something far more valuable than farmland. It offered potential freedom to anyone seeking to distance himself from a European society that could at times be quite oppressive. Fugitive African slaves, for example, sometimes looked upon the remote Appalachian Mountains as a place of refuge from white bondage. Occasionally forming themselves into small maroon communities, groups of escaped slaves tried to sustain themselves, and their freedom, by hunting wild game and farming the land. ${ }^{178}$ Other fugitive slaves survived on the frontier by becoming "Indians." Consider the unlikely case of Selim, a highly educated Muslim from a well-to-do Algerian family. After being captured in the Mediterranean Sea by pirates and sold as a slave in New Orleans, Selim escaped inland ultimately falling in with the Shawnees by the mid-1750s. ${ }^{179}$ Whether he joined them willingly or had been captured and adopted into the tribe is unclear. Regardless, he would have enjoyed the same freedoms as any other Shawnee. ${ }^{180}$

${ }^{176}$ Diary $G W, 1: 65$.

${ }^{177}$ Withers, Chronicles of Border Warfare, 74-75.

${ }^{178}$ Herbert Aptheker, American Negro Slave Revolts (New York: International Publishers, 1963), 179.

${ }^{179}$ Oren F. Morton, Annals of Bath County Virginia (1917; reprint, Harrisonburg, Va.: C. J. Carrier, 1978), 101-3; McNeill, Tales, 51-52.

${ }^{180}$ James H. Howard, Shawnee!: The Ceremonialism of a Native American Tribe and Its Cultural Background (Athens: Ohio University Press, 1981), 123. 
Soldiers also sometimes fled to the frontier to free themselves from the brutality of British military "justice." At a time when punishment for regular troops might entail receiving two hundred lashes with a cat and nine tails for drunkenness or eight hundred lashes for stealing a keg of beer, the remoteness of a distant frontier could be quite appealing. ${ }^{181}$ Of course, any regular soldier who deserted his unit risked being "hanged without mercy" if apprehended. ${ }^{182}$ Perhaps the most famous "West Virginia" refugees from the military included brothers John and Samuel Pringle who deserted the British garrison at Fort Pitt in 1761. After narrowly evading capture, the Pringles eventually withdrew deep into the forests of western Virginia where they ultimately took up residence inside a large hollow sycamore tree. ${ }^{183}$

This series of pioneer sketches closes with a slightly longer narrative account of the German-born Eckerlin brothers, Israel, Gabriel, and Samuel. One-time members of the monastic Ephrata cloister located near Lancaster, Pennsylvania, the Eckerlins at some point in the early $1740 \mathrm{~s}$ became interested in relocating to the frontier. Following two failed attempts in 1745 and 1751, they successfully established a settlement in 1752 at a site along the Cheat River that would soon become known as "Dunkard Bottom." There they lived in friendship with the local Delawares with whom they traded and provided medical care. In fact, it had been the Delawares that suggested that the Eckerlins live at Dunkard Bottom because its remote location would be

${ }^{181}$ Franklin Thayer Nichols, “The Organization of Braddock's Army," The William and Mary Quarterly 4 (April 1947): 142-43.

${ }^{182}$ Major General Edward Braddock's Orderly Books, From February 26 to June 17, 1755 (Cumberland, Md.: Will H. Lowdermilk, 1878), v.

${ }^{183}$ Withers, Chronicles of Border Warfare, 117-19. 
fairly safe from hostile Indians allied with the French. ${ }^{184}$ Samuel Eckerlin eventually petitioned and received a five thousand acre land grant that included Dunkard Bottom. ${ }^{185}$

According to Brother Samuel, the Eckerlins had originally looked westward because it was "time again to turn to a hermit's life." 186 But if being a hermit implied living a contemplative life of solitude, prayer, voluntary poverty, and simplicity, then the Eckerlins were anything but hermits. On the contrary, the brothers soon embarked on a course aimed at creating a frontier religious community under their personal leadership. Unlike the more mainstream Lutherans or Presbyterians, the Pietist-influenced Eckerlins advocated monasticism, celibacy, pacifism, and communalism. Additionally, they observed the Sabbath on Saturdays, did not perform baptisms, refused to cut their beards, and practiced vegetarianism when circumstances permitted. ${ }^{187}$ If anyone possessed the skills and knowledge needed to create a monastic religious community on the frontier, it was the Eckerlins. Brother Israel wrote prolifically, practiced medicine, had a good head for business, and as one-time prior at the Ephrata cloister, he had demonstrated great skill at organizing and leading men. Brother Samuel, also known as Doctor Eckerlin, likewise practiced medicine, but also excelled at agriculture and knew how to process animal hides and skins.

Brother Gabriel proved himself particularly adept at hunting, an invaluable skill on the western

${ }^{184}$ Lamech and Agrippa, Chronicon Ephratense; A History of the Community of Seventh Day Baptists at Ephrata, Lancaster County, Penn'a, trans. J. Max Hark (Lancaster, Pa.: S. H. Zahm, 1889), 224, 229-30.

${ }^{185}$ Hall, Executive Journals of the Council, 450.

${ }^{186}$ Lamech, Chronicon Ephratense, 184.

${ }^{187}$ Thomas Walker, Journal of an Exploration in the Spring of the Year 1750, ed. William C. Rives (Boston: Little, Brown, and Company, 1888), 39-40. 
Virginia frontier. ${ }^{188}$

Between 1753 and 1756, the Eckerlins worked hard at creating their religious community. An eyewitness visitor to the Eckerlin's Cheat River "hermitage" described a crude yet thriving settlement consisting of the brothers, an indentured servant, a hired cook, six acres of planted corn, a hundred bushels of harvested corn, twenty-eight horses, and over a hundred British pounds worth of animal skins. ${ }^{189}$ Rather than live in isolated solitude, the brothers wrote long letters to associates in the east and made frequent trips back to the Shenandoah Valley and Ephrata. On some of these trips, they met with merchants in an effort to open regular trade between the Cheat River and eastern Pennsylvania. The brothers additionally made it known that Anabaptists and other pious individuals would be welcome in their community. ${ }^{190}$ Unfortunately for the Eckerlins, as we will see, the French and Indian War ended their chances of succeeding in their holy venture.

The above series of sketches illustrate the important point that ethnic and social diversity existed in western Virginia from the earliest days of settlement. A traveler passing through the region in 1753 might have encountered animistic Native Americans from a half dozen tribes,

${ }^{188}$ Lamech, Chronicon Ephratense, 224, 230; Emmert F. Bittinger, Allegheny Passage: Churches and Families, West Marva District, Church of the Brethren 1752-1990 (Camden, Maine: Penobscot Press, 1990), 21.

${ }^{189}$ For an English translation of Henry Sangmeister's eyewitness description of the Eckerlin's Cheat River hermitage, see Donald F. Durnbaugh, ed., The Brethren in Colonial America: A Source Book on the Transplantation and Development of the Church of the Brethren in the Eighteenth Century (Elgin, Ill.: Brethren Press, 1967), 164.

${ }^{190}$ Lamech, Chronicon Ephratense, 230; Klaus Wust, The Saint-Adventurers of the Virginia Frontier: Southern Outposts of Ephrata (Edinburg, Va.: Shenandoah History, 1977), 30-31. 
Englishmen who had embraced the religious views of a German Evangelical Lutheran, an Islamic scholar from North Africa, Scots-Irish Presbyterians from the plantations of Ulster, German Pietists with an inclination toward religious mysticism and monasticism, English squatters, and a diverse array of hunters, trappers, indentured servants, escaped slaves, and fugitives from justice. In short, the so-called archetypal pioneer of popular imagination was anything but typical on the western Virginia frontier.

Despite their diverse cultural differences, the pioneers did share at least one common trait. Regardless of their nationality, religious views, economic standing, social position, attitude toward the Indians, or purpose for being on the frontier, the pioneers universally risked hardship, injury, and death at the hands of Indian warriors. Let us return once more to the pioneer sketches presented above to see how those men and women ultimately fared. In the fall of 1753 almost a year prior to the outbreak of the French and Indian War, a suspected Ottawa war party attacked the pioneer settlement referred to by George Washington as being in the Kanawha Valley. According to some Iroquois who later stumbled upon the carnage, seven settlers had been killed and scalped with their bodies subsequently being "much torn and eaten by Hogs." ${ }^{, 191}$ About that same time, Indians also struck the family of Robert Files situated near the Seneca Indian trail. From a distance, one of the children helplessly watched the Indians kill and scalp his parents and five siblings. He later ran the two miles to the cabin of his neighbor David Tygart to warn him of the danger. Only by abandoning their homestead and fleeing the frontier did the Tygart family and remaining Files boy survive. ${ }^{192}$ Even Stephen Sewel, the first documented settler in "West
${ }^{191}$ Diary $G W, 1: 65$.
192“Preston's Register of Persons Killed, Wounded, or Taken Prisoner . . .,” Draper 
Virginia" died at the hands of an Indian warrior in September $1756 .{ }^{193}$ For the next forty years, pioneer families repeatedly found themselves in the position of David Tygart and Stephen Sewell where a decision had to be made whether to risk remaining on the dangerous frontier or to withdraw back across the mountains. In many cases, it ultimately became a matter of life or death.

Unfortunately, not every frontiersman had the option of fleeing the frontier during times of danger. For the Pringle brothers, being recognized and apprehended as deserters could be just as perilous as remaining in the backcountry. Likewise, fugitive criminals who had found respite on the frontier could not simply return to the east at will. Simon Kenton, for example, had fled across the mountains thinking he had killed a man in a fight. ${ }^{194}$ Indentured servants and African slaves likewise did not enjoy complete freedom of movement. Although escaped slaves, such as Selim, sometimes joined with the Indians, ${ }^{195}$ others fought against them alongside their masters. Consider Dick Pointer, a slave in the Greenbrier Valley whose heroism in battle against the Indians would later in life earn him his freedom and financial support from an appreciative white populace. ${ }^{196}$ Although Pointer gained local notoriety as an Indian fighter, did he really have that

Manuscripts, 1 QQ 83, State Historical Society of Wisconsin; Withers, Chronicles of Border Warfare, 74-75; Hu Maxwell, The History of Randolph County, West Virginia (1898; reprint, Parsons, W. Va.: McClain, 1991), 180-82.

193“"Preston's Register,” Draper Manuscripts, 1 QQ 83, HSW.

${ }^{194}$ “Notes on Gen. Simon Kenton - 1771-'73,” Draper Manuscripts, 1 BB 3-13, HSW; Edna Kenton, Simon Kenton; His Life and Period, 1755-1836 (Garden City, N. Y.: Doubleday, Doran, 1930), 24-28.

${ }^{195}$ As seen in the previous chapter, even the process of adoption involved violence and the risk of injury or death. 
many viable options? Unlike David Tygart, Pointer did not have the freedom to decide whether to risk remaining on the frontier or to return to the east.

Even religious pacifism and overt goodwill toward the Indians could not guarantee immunity from Indian-related violence. Perhaps more than anyone, the Eckerlin brothers epitomize the universality of the hardship endured by the pioneers during the western Virginia Indian wars. At a time when most frontiersmen looked upon the Indians with deep suspicion if not outright enmity, the brothers embraced them as friends. On occasion, the Eckerlins, "who are all Doctors," even treated sick or injured Delawares and Shawnees. ${ }^{197}$

Despite their goodwill and tolerance, the Eckerlins by 1756 found themselves caught literally on the front lines of the French and Indian War. Unfortunately, the pacifism and neutrality touted by the brothers became an increasingly untenable position as participants from both sides began looking upon them with suspicion. Even George Washington registered his distrust of the Eckerlins in a pair of letters to Governor Robert Dinwiddie explaining, "I firmly believe they are employed as spies, and are useful to the French." 198 After all, they "entertain the Indians who are wounded here."199 The Virginians' deep distrust of the Eckerlins is reflected in the fact that they even went so far as to deploy a company of eighty men to the Cheat River to bring in the brothers. The soldiers failed to locate the hermitage, however, a party of Iroquois did

${ }^{196}$ Louise Phelps Kellogg, ed., Frontier Advance on the Upper Ohio, 1778-1779 (Madison: Wisconsin Historical Society, 1916), 69-70, $72-73$.

${ }^{197}$ Washington to Dinwiddie, 28 September 1756, Writings GW, 1:475.

${ }^{198}$ Washington to Dinwiddie, 5 October 1757, Writingd GW, 2:142-43.

${ }^{199}$ Washington to Dinwiddie, 28 September 1756, Writings $G W, 1: 475$. 
discover them. Although the Eckerlins lost their clothing and furs in the encounter, they suffered no bodily harm. Sensing the escalating danger, the local Delawares advised the brothers to leave the frontier at once because their hermitage would no longer be secure. When the Eckerlins chose to disregard the warning, they sealed their own fate. ${ }^{200}$

The following year, the Virginians arrested Brother Samuel while on one of his frequent trips to the Shenandoah Valley. By compelling him to serve as a guide, Captain Robert McKenzie marched a party of seventy men to the Cheat River in order to "bring in the other two Brothers, with their Cattle \& Horses \& any Thing . . . they conveniently can bring with them."201 Along the way, McKenzie's soldiers reportedly treated "Brother Samuel rather roughly . . . trusting that they would be proven right in assuming him and his brothers spies." Upon arriving at the Eckerlins' hermitage, they found broken tomahawks, Indian spears, and the burnt out remains of some cabins. $^{202}$ Indians had destroyed the hermitage and taken its occupants captive. Captain McKenzie subsequently released Brother Samuel who had been vindicated of all suspicions of working as a French spy.

Unfortunately, brothers Israel and Gabriel along with an indentured servant named John Schilling did not fare as well. Shortly before the Virginians arrived at the hermitage, a war party of seven Ottawas and one Frenchman had captured the three men who offered no resistance. During their subsequent eight day trip to Fort Duquesne at present Pittsburgh, the Indians "sorely

${ }^{200}$ Lamech, Chronicon Ephratense, 231.

${ }^{201}$ Dinwiddie to Washington, 24 October 1757, Letters to Washington and Accompanying Papers, vol. 2, 1756-1758, ed. Stanislaus Murray Hamilton (Boston: Houghton, Mifflin, 1899), 218.

\footnotetext{
${ }^{202}$ Wust, Saint-Adventurers, 36-37.
} 
mistreated" the brothers including scalping the beard from one of them. At Fort Duquesne, the Ottawas sold the two Eckerlins to the French, but retained Schilling for themselves. ${ }^{203}$ Over three years later, Schilling made his escape ultimately finding his way back to Pennsylvania. The brothers, on the other hand, reportedly endured a frigid winter in a prison at Quebec "where they suffered for want of necessary Food and Clothing."204 Becoming ill with "a distemper," Israel and Gabriel Eckerlin were ultimately shipped to France where they both succumbed to their afflictions. $^{205}$

The frontier experiences of Stephen Sewel, the Files family, Dick Pointer, the Eckerlins, and the hundreds of settlers who fled their homes to escape Indian warfare tells us that the cultural background of a particular settler had little influence in how they ultimately fared in relating to the Indians. Even the life of the most avowed pacifist could quickly be destroyed by a single encounter with a hostile warrior. Much of the difficulty in relating with the Indians is that they, like the pioneers themselves, tended to be a very heterogenous lot hailing from a multitude of linguistic groups, tribes, clans, villages, and extended families each with their own particular beliefs, attitudes, and agendas. In the face of such Native American diversity, the old adage that you cannot please everyone" rings particularly true. A carefully cultivated relationship with one village or tribe did not necessarily translate into an amiable relationship with all Indians. So for the Eckerlins, it mattered little that the local Indians held them in great esteem because in the end,

${ }^{203}$ Lamech, Chronicon Ephratense, 232.

${ }^{204}$ Pennsylvania Gazette, 26 January 1758.

${ }^{205}$ Lamech, Chronicon Ephratense, 232-33; Samuel Eckerlin to Benjamin Franklin, 5 November 1764, The Papers of Benjamin Franklin, ed. Leonard W. Labaree (New Haven: Yale University Press, 1967), 11:443-44. 
not every Indian that passed through western Virginia had local connections.

When scholars make reference to the "frontier experience" in West Virginia, it is important to bear in mind that the so-called "frontier experience" actually refers to the collective experiences of the individual pioneers who had been there. So would it be premature at this point to generalize the frontier experiences of fewer than a dozen settlers who had bad encounters with the Indians to the entire pioneer population of western Virginia? When we consider that every last settler in western Virginia had either been killed, taken captive, or driven from their homesteads by early 1758 , the answer to this question would have to be "no," it is not premature. ${ }^{206}$ Every settler in western Virginia during the 1750 s to one degree or another experienced the dangers, fears, and hardships of Indian warfare. ${ }^{207}$

At this point we can begin to discern the temporal influence that Indian-related violence exerted on the duration of the frontier period of "West Virginia" history. After six years of opportunistic raiding and angry resistance to white settlement, Indian warriors had left western Virginia no closer to being settled than it had been in 1749 when Sewel and Marlin first occupied their cabin near the Greenbrier River. In effect, Indian attacks had already begun to prolong the duration of frontier conditions in the western Virginia backcountry.

Of course, any discussion involving the pace of frontier settlement and development is meaningless unless the region in question can be compared directly with another frontier zone. For the purposes of this study, a comparison will be made between two different regions of

${ }^{206}$ Washington to Dinwiddie, 8 September 1756, Writings $G W, 1: 466$.

${ }^{207}$ For insight into how warfare broadly affected Virginians during the mid-eighteenth century, see Chester Raymond Young, "The Stress of War Upon the Civilian Population of Virginia, 1739-1760," West Virginia History 27 (July 1966): 251-77. 
Appalachian Virginia: the trans-Allegheny region situated between the Ohio River to the west and the Allegheny Mountains to the east, and the Shenandoah Valley nestled between the Blue Ridge to the east and the hill and valley region toward the west.

The benefits of using the Shenandoah Valley as a basis of comparison are numerous. First, by selecting a region located within the same colony as trans-Allegheny Virginia, we can avoid the confusion and complexities that would arise by comparing two regions that operated under separate political and legal systems. Second, the two regions are situated near one another and include some similar geologic and geographic features. Third, the historical development of the Shenandoah Valley frontier has already been thoroughly studied by scholars such as historical geographer Robert Mitchell. And fourth, the two regions shared some common historical processes that help us to understand the relationship between Indian violence and the duration of frontier living conditions. An important part of this shared history revolved around Virginians' perceptions of the Appalachian backcountry and how those perceptions led to the adoption of colonial administrative policies aimed at securing the western borders of the colony through the encouragement of large-scale land speculation and the use of frontier settlers as "human shields." Having said that, let us see what it means.

Throughout much of the colonial period, Virginians looked upon their mountainous western border with a sense of ambivalence. On the one hand, the rugged backcountry had much to offer including room for expansion, farmland, the fur trade, mineral wealth, valuable timber, and an enlarged empire. At the same time, however, many Virginians looked westward with a sense of apprehension and dread. Like the siren of Greek mythology that simultaneously enticed 
and destroyed, the Appalachian Mountains held forth the promise of wealth and opportunity yet posed many dangers both mythical and real. Some of the alleged hazards included deadly “mountain-spiders," women warriors skilled with the use of a bow, packs of wolves, giant rattlesnakes that could hypnotize their prey, lions, huge carnivorous elephants, and miles of trackless forest where a man could become lost forever. Although most Virginians appear to have ceased debating the existence of armies of women archers by the Revolutionary War, they had not yet entirely ruled out the possibility of flesh-eating paciderms. ${ }^{208}$

The greatest concern, however, arose from potential human foes. Early on, geographically illiterate colonists sometimes expressed concerns over the possible presence of Spaniards just west of the Blue Ridge in California. By the early eighteenth century, however, Virginians had largely realized that no European rival posed a direct threat to the security of their western frontier. Even the French at the height of the French and Indian War lacked the ability to single handedly mount a credible challenge to English claims of ownership of the upper Ohio Valley. In reference to Fort Duquesne, the Marquis de Vaudreuil, governor of Canada, admitted in 1756 that if the British launched an attack, "in the present state of the fort, it would be

${ }^{208}$ For mountain-spiders, women warriors, and giant rattlesnakes, see John Lederer, The Discoveries of John Lederer. (1672; reprint, Rochester, N. Y.: George P. Humphrey, 1902), 910, 20-21, 25. Throughout the Ohio Valley, particularly at Big Bone Lick, Kentucky, the pioneers periodically discovered old tusks, molars, and bones from huge animals. The giant bones evoked quite a debate with some people speculating that the tusks came from a giant carnivorous American elephant that might still live somewhere on the frontier. Others theorized that the tusks belonged to a hippopotamus. Today we know that the remains came from extinct wooly mammoths, mastodons, and giant ground sloths. Johann David Schoepf, Travels in the Confederation, 1783-1784 (New York: Burt Franklin, 1968), 266-70; Thomas Jefferson, Notes on the State of Virginia (New York: W. W. Norton, 1972), 43-47, 53-54. 
impossible to make any resistance for any length of time."209 The Marquis de Montcalm put it more bluntly by stating that "Fort Duquesne is not worth a straw." 210 The real source of French power lay not in their own forts or soldiers, but in their ability to summon aid from the Indians. ${ }^{211}$

Virginians had good reason to fear the Indians. From the earliest years of the Virginia Colony, Indian warriors time and again had ravaged the frontier settlements terrorizing and killing settlers by the hundreds. Often carried out in the name of self-preservation or in retaliation for abusive treatment at the hands of Europeans, Indian warfare repeatedly dealt serious setbacks to English colonization. One particularly devastating attack occurred in March 1622 when warriors under the leadership of Chief Opechancanough killed one third of the approximately one thousand colonists in Virginia. ${ }^{212}$

From the ashes of this attack emerged one of the more influential pieces of legislation to be passed in seventeenth-century Virginia, the 1630 land law. The key element of this law involved making land grants available directly to groups of settlers willing to relocate and live at exposed strategic locations on the frontier. Based on the English concept that possession and

${ }^{209}$ Doc. His. N.Y., 10:425.

${ }^{210}$ Doc. His. N.Y., 10:416.

${ }^{211}$ Montcalm's aide-de-camp Louis Antoine de Bougainville summed up French dependence on their Indian allies when he said "In the midst of the woods of America one can no more do without them than without cavalry in open country." Quoted in Colin G. Calloway, New Worlds for All: Indians, Europeans, and the Remaking of Early America (Baltimore: Johns Hopkins University Press, 1997), 105.

${ }^{212}$ Edward Waterhouse, "A Declaration of the State of the Colony and . . . A Relation of the Barbarous Massacre ...," in Records of the Virginia Company of London, ed. Susan M. Kingsbury (Washington: Government Printing Office, 1933), 3:565-571; Richard L. Morton, Colonial Virginia (Chapel Hill: University of North Carolina Press, 1960), 1:74-75. 
"improvement" of the land created ownership of that land, the settlers would serve two primary purposes. First, their physical presence would assert English dominion over that land and second, the settlers would serve as the first line of defense in the event of an Indian uprising. In other words, the settlers would constitute a buffer zone, or human shield. Although few settlers actually took advantage of the law at the time, it became the basis of Virginia's frontier defense policy for the next one hundred thirty years. ${ }^{213}$

In 1701, the General Assembly of Virginia revised the land law by placing greater emphasis on its military and defensive aspects. The new law invited organized groups of no fewer than twenty "warlike Christian men" to petition the government to receive between ten thousand and thirty thousand acres of frontier land at no cost to them. In fact, they would even be exempted from paying taxes or levies for the next twenty years. Holding the overall tract of land as tenants in common, each man would individually receive two hundred acres of farmland and a smaller town lot. In exchange for the land and tax exemptions, the government required the men to construct a stout half acre fort, organize themselves into a military unit under a governorapproved commander, and equip themselves with a musket, pistol, sword, tomahawk, five pounds of powder, and twenty pounds of lead. ${ }^{214}$ Although legislators hoped to permanently solve the perennial problem of frontier defense, the policy once again engendered only minimal enthusiasm from the public. ${ }^{215}$

${ }^{213}$ Ray Allen Billington, Westward Expansion: A History of the American Frontier (New York: Macmillan Publishing, 1974), 54.

${ }^{214}$ William Waller Hening, ed., The Statutes at Large; Being a Collection of All the Laws of Virginia, 1619-1792 (Richmond: 1809-23), 3:204-8.

${ }^{215}$ Otis K. Rice, The Allegheny Frontier: West Virginia Beginnings, 1730-1830 
Not yet ready to abandon the idea that land grants could somehow be translated into frontier defense, the colonial government in 1730 again reworked the land law. Unlike the previous version, the new law entirely eliminated all references to "warlike Christian men," forts, military service, or mandatory lists of required weaponry. Instead, the law commercialized the process of frontier settlement by thrusting land speculators into a prominent intermediary position between the government and would-be settlers. Under the new guidelines, speculators could petition the government for up to one hundred thousand acres of frontier land. In return, they had to meet only three simple stipulations. First, one bonafide family had to be settled within their grant for every thousand acres received. Second, the speculators had a two year time limit in which to settle the families. And third, so as to not depopulate the eastern portions of the colony, the families had to come from somewhere outside of Virginia. ${ }^{216}$

The new land policy garnered immediate widespread interest from speculators and settlers alike. Over the next two decades, millions of acres of frontier land in the Shenandoah Valley and trans-Allegheny Virginia would be distributed to dozens of different speculative interests. Some of the more prominent Shenandoah Valley speculators included Jacob Stover, Joist Hite, Robert McKay, brothers John and Isaac Van Meter, Benjamin Borden, James Patton, William Beverly, and Alexander Ross. Prominent speculative interests west of the Allegheny Mountains included not only individuals such as Thomas Lewis, Ambrose Powell, Henry Downs, and Andrew Lewis, but also large incorporated land companies whose membership read like a veritable who's who of

(Lexington: University Press of Kentucky, 1970), 20.

${ }^{216}$ Thomas Perkins Abernathy, Three Virginia Frontiers (Gloucester, Mass.: Peter Smith, 1962), 54-55; Rice, Allegheny, 20. Speculators typically received four years rather than two years to settle families on land grants situated in the more remote trans-Allegheny region. 
political influence, power, and experience in Virginia politics. The leadership of the Greenbrier Company, Ohio Company, and Loyal Land Company included among others Thomas Lee, George Fairfax, George Mason, Thomas Cresap, Augustine Washington, Lawrence Washington, William Beverly, and Charles Lewis. ${ }^{217}$ Large-scale commercial land speculation quickly became such a ubiquitous facet of frontier life that we can easily lose sight of the fact that its original purpose involved defending the colony against Indian attacks.

With a vested economic interest in meeting the government's requirement that settlers be brought in from outside the colony, speculators had little choice but to become both promoters and recruiters. While most settler recruitment appears to have taken place amongst the Germans, Swiss, Welsh, Scots-Irish, and English living in the Middle Atlantic colonies, speculators also looked toward Europe as a potential source for families. Ship captain and land speculator James Patton, for example, recruited and imported Scots-Irish immigrants into the Shenandoah Valley during the late 1730s. ${ }^{218}$ Likewise, before the French and Indian War rendered settlement untenable in western Virginia, the Ohio Company envisioned recruiting settlers from amongst the German Protestants of the Rhineland. ${ }^{219}$ As an incentive to settle on their lands, some speculators even offered prospective families legal and financial services such as extending them lines of

${ }^{217}$ Robert D. Mitchell, Commercialism and Frontier: Perspectives on the Early Shenandoah Valley (Charlottesville: University Press of Virginia, 1977), 26-36; Rice, Allegheny, 20-21.

${ }^{218}$ Patricia Givens Johnson, James Patton and the Appalachian Colonists, $2 \mathrm{~d}$ ed. (Pulaski, Va.: Edmonds Printing, 1983), 9-10.

${ }^{219}$ Alfred P. James, The Ohio Company: It's Inner History (Pittsburgh: University of Pittsburgh Press, 1959), 16. 
credit. $^{220}$ For an immigrant family from a non-English speaking country, help with deeds, lands surveys, and financing would have been invaluable.

Even the Anglican government of Virginia facilitated the recruitment of "foreign" families by encouraging non-Anglican Protestants to settle on the western frontier. In 1738, for example, Virginia Governor William Gooch informed the Synod of Philadelphia that Presbyterian ministers serving west of the Blue Ridge "may be assured that no interruption shall be given ... so as they conform themselves to the rules prescribed by the Act of Toleration in England, by taking the oaths enjoined thereby, and registering the place of their meeting."221 In 1752, the General Assembly passed legislation for encouraging Protestant dissenters to settle on the western waters by exempting them "from the payment of all public, county, and parish levies, for the term of ten years."222 The following year, the Assembly extended the duration of the tax exemption to fifteen years for all Protestants living west of the mountains. By encouraging foreign Protestants to settle on the frontier, legislators hoped to "add to the strength and security of the colony."223 Thus, the threat of Indian attacks directly led the government of Virginia to adopt legislation that promoted both ethnic diversity and religious plurality in the western Virginia backcountry.

Up to this point, the two Virginia frontier regions had experienced several common elements in their historical background and development. This shared heritage included among

${ }^{220}$ Rice, Allegheny Frontier, 22.

${ }^{221}$ William Gooch quoted in Records of the Presbyterian Church in the United States (Philadelphia: Presbyterian Board of Publication, 1841), 147.

${ }^{222}$ Hening, Statutes at Large, 6:258.

${ }^{223}$ Hening, Statutes at Large, 6:355-56. 
other things, having reputations as being places filled with both opportunity and danger, serving as testing grounds for governmental land policies which married large scale commercial land speculation with frontier defense, and being populated by settlers characterized by ethnic, racial, and religious diversity. In addition, the two regions also shared the same local government. From 1738 through 1769, for example, almost all of trans-Allegheny Virginia fell within Augusta County with its seat located at Staunton in the Shenandoah Valley.

By the early 1750s, however, the developmental history of trans-Allegheny Virginia and the Shenandoah Valley began to diverge in terms of how rapidly the region became settled and living conditions improved. In his study of the Shenandoah Valley, historical geographer Robert Mitchell found that the crude phase of frontier life typically ended within a year or two after initial permanent settlement. ${ }^{224}$ What factors enabled the Shenandoah Valley frontier to progress so rapidly? In contrast with trans-Allegheny Virginia, the Shenandoah Valley possessed several advantages including greater proximity to the coast, access to east-flowing watercourses, and larger expanses of relatively level farmland. In addition, Mitchell pointed out that "the Shenandoah Valley had not been inhabited by any resident Indian tribes for a considerable period of time." It was this "absence of sedentary Indians [that] allowed for a more peaceful and orderly settlement of the area." ${ }^{225}$ So even though the Shenandoah region had a lot going for it, the biggest advantage appears to have been the absence of long-term Indian-related violence.

Conversely, settlers west of the Allegheny Mountains had many disadvantages to overcome with the most obstinate challenge being the Indians.

\footnotetext{
${ }^{224}$ Mitchell, Commercialism and Frontier, 3.

${ }^{225}$ Mitchell, Commercialism and Frontier, 16, 19.
} 
Like the settlers themselves, the colonial and imperial governments also struggled to resolve the challenges posed by Indians in the upper Ohio Valley. As the French and Indian War dragged on into 1758, Virginians increasingly found themselves at odds with royal officials in policy matters relating to the Indians, frontier defense, and settlement. To a great extent, these emerging differences between crown and colony stemmed from their very different perspectives on the war itself and what constituted an acceptable outcome. For many Virginians, the primary objectives of the French and Indian War involved broadly defining the geographical boundaries of the colony and insuring that Virginians had the freedom to speculate in western lands, engage in the Indian trade, and settle on the frontier. From the less parochial British perspective, the war entailed a global struggle for empire against their longtime French rival. The Seven Years War, as it would be known in Europe, occurred in several theaters throughout the world and placed a tremendous burden on the shoulders of British taxpayers. By the war's end in 1762, Britain would accumulate a staggering debt of, 133 million pounds with an additional, 4.3 million pounds accruing annually in interest charges. ${ }^{226}$ Naturally, it behooved the British to quickly resolve their struggle in the remote Ohio Valley even if it entailed making concessions to the Indians that colonial settlers, land speculators, and Indian traders would largely find unacceptable.

Where for decades Virginians had pursued a very confrontational style of frontier defense involving the placement of settlers at strategic locations within Indian territories, British officials starting in 1758 began to impose a new policy aimed at placating the Indians by closing the frontier to settlement. The first major step toward instituting this new policy occurred at the

\footnotetext{
${ }^{226}$ Stephan Thernstrom, A History of the American People, vol. 1 (New York: Harcourt Brace Jovanovich, 1984), 129.
} 
October 1758 Council of Easton held approximately fifty miles north of Philadelphia. Attended by over five hundred Indians representing thirteen different bands and tribes, Governor William Denny of Pennsylvania made a major announcement. Through negotiations conducted by British Indian Superintendent Sir William Johnson, the proprietors of Pennsylvania "cheerfully agreed to release" the Iroquois from having to abide by the Albany Treaty which just three years earlier had transferred ownership of western Pennsylvania to the English. ${ }^{227}$ In other words, all of Pennsylvania west of the Allegheny Mountains would be restored to the Iroquois Confederacy. Consequently, white settlement there was prohibited. Restoring this land to the Iroquois implied that the Shawnees, western Delawares, and Ohio Iroquois would be allowed to live in western Pennsylvania without interference from settlers.

Although not a total panacea, the Treaty of Easton went a long way toward resolving some major British problems in the upper Ohio Valley. Immediately after announcing the settlement ban, messenger Frederick Christian Post along with the Delaware sachem Pisquetomen rushed from Easton across the colony to Fort Duquesne where the French and Indians busily prepared to meet the approaching army of General John Forbes. When the Shawnees and western Delawares learned that the frontier had been closed to settlement, they abandoned their French allies and made peace with the English. After all, it appeared as if they had achieved their military objective. As most of their Indian supporters melted away, the French had little choice but to destroy Fort Duquesne and abandon the Forks of the Ohio. In its place, the British built the

${ }^{227}$ Samuel Hazard, ed., Minutes of the Provincial Council of Pennsylvania [spine title: Colonial Records] (Harrisburg: Pennsylvania, 1852), 3:204. 
considerably more imposing Fort Pitt. ${ }^{228}$

Over the next five years, royal officials expanded and elaborated on the new frontier policy. High-ranking army officers charged with defending the frontier had a particular interest in upholding the treaty because to a great extent, it determined the difference between war and peace with the Ohio tribes. In fact, the British had even been told as much when the prominent Delaware sachem Keekyuscung (also known as Ketiushund) sent a friendly warning to the "Governor, General, and all other people" that if they "staid and settled" in their hunting grounds, all of the Ohio tribes "would be against them; and he was afraid it would be a great war, and never come to a peace again. ${ }^{229}$ Not surprisingly, British commanders repeatedly told the Indians exactly what they wanted to hear. A week after Forbes' army seized control of the Forks of the Ohio, Colonel Henry Bouquet informed the Delawares that "We have not come here to take possession of your hunting Country ... but to open a large and extensive Trade with you ... to serve you in every necessary you want, and on the cheapest Terms.. ${ }^{230}$ General Robert Monckton reiterated the point when he assured a council of Shawnee, Delaware, Iroquois, Ottawa, and Wyandot chiefs that "His Majesty has not sent me to deprive any of you of your Lands and Property." ${ }^{231}$ And so as to leave absolutely no doubt regarding the imperial position,

${ }^{228}$ Christian Frederick Post, "Two Journals of Western Tours," in Early Western Travels, 1748-1846, vol. 1, ed. Reuben Gold Thwaites (Cleveland: Arthur H. Clark), 1904), 254-59; Fred Anderson, Crucible of War: The Seven Years' War and the Fate of Empire in British North America, 1754-1766 (New York: Vintage, 2000), 280-81.

${ }^{229}$ Post, “Two Journals of Western Tours", 278.

${ }^{230}$ Penn. Archives, 3:572.

${ }^{231}$ Penn. Archives, 3:745. 
Colonel Bouquet on 30 October 1761 issued a formal proclamation at Fort Pitt reiterating the ban on settlement and hunting west of the mountains. ${ }^{232}$ In fact, Bouquet even went so far as expand the settlement ban to include western Maryland and western Virginia as well. Anyone who violated the ban, he announced, would be arrested, delivered to Fort Pitt, and tried by court martial. $^{233}$

Despite the efforts of British officials to close the trans-Allegheny frontier, dozens of pioneers flaunted the law by crossing the mountains anyway. In the fall of 1758 , for example, Thomas Decker "and some others" established homesteads at the mouth of Deckers Creek in present Morgantown. ${ }^{234}$ Over a hundred settlers likewise returned to the Greenbrier region by 1763. ${ }^{235}$ John and Samuel Pringle likewise disregarded the settlement ban by continuing to live west of the Allegheny Mountains. ${ }^{236}$ Unfortunately, there is simply no way of determining precisely how many hunters and settlers violated the law.

When examining laws and regulations of the past, historians must bear in mind that in many instances, laws represent a theoretical vision of how the lawmaker(s) would like society to be and do not necessarily reflect actual conditions. Oftentimes, laws are only partially upheld

${ }^{232}$ Jack M. Sosin, Whitehall and the Wilderness: The Middle West in British Colonial Policy, 1760-1775 (Lincoln: University of Nebraska Press, 1961), 42.

${ }^{233}$ Randolph C. Downes, Council Fires on the Upper Ohio: A Narrative of Indian Affairs in the Upper Ohio Valley until 1795 (Pittsburgh: University of Pittsburgh Press, 1968), 114.

${ }^{234}$ Alexander Scott Withers, Chronicles of Border Warfare (1895; reprint, Parsons, W. Va.: McClain, 1989), 77.

${ }^{235}$ Stuart, "Memorandum, 1798," 367; John Stuart, Memoir of Indian Wars and Other Occurrences (1833; reprint, Parsons, W. Va.: McClain, 1971), 5.

${ }^{236}$ Withers, Chronicles of Border Warfare, 117-18. 
because of the high economic costs of enforcement. ${ }^{237}$ Speeding, jay walking, copyright infringement, and tax evasion are only a few modern examples of "crimes" that frequently go unmonitored and unpunished because of the high enforcement costs.

During the early 1760s, the violation of the settlement ban west of the Allegheny Mountains likewise constituted a crime that saw only limited enforcement because of the high costs involved. From an economic perspective, the commandant at Fort Pitt simply lacked sufficient soldiers and resources to patrol the entire backcountry turning away would-be settlers. Settlers fully realized this limitation so they intentionally kept far away from the forts so as to avoid detection by the authorities. ${ }^{238}$ And even if the military had been able to apprehend the squatters, just how heavy-handed could they be in imposing the settlement ban on civilians? Bouquet at one point ordered that the cabins of "squatters" be burnt, and on another occasion Sergeant Angus McDonald confiscated some horses belonging to illegal settlers. Not surprisingly, both actions failed to stem the flow of squatters crossing the mountains. McDonald even contemplated posting a sign "at the Great Crossings to give them [squatters] Notice Then I Could Handle them more Ruffer if they Should Come again." ${ }^{\text {239 }}$ Judging by his words, McDonald evidently felt somewhat constrained in how harshly he could deal with squatters. In short, Bouquet and McDonald had both discovered that the high social, political, and economic costs of enforcing the settlement ban had rendered it largely untenable. They could do little to stop

${ }^{237}$ Douglas North, Structure and Change in Economic History (New York: Norton, 1981), 28.

${ }^{238}$ McDonald to Bouquet, 25 October 1761, Bouquet Papers, series 21647, 175.

${ }^{239}$ James Kenny quoted in Downes, Council Fires on the Upper Ohio, 114; McDonald to Bouquet, 25 October 1761, Bouquet Papers, series 21647, 175. 
squatters from occupying Indian territory.

By early 1762, just as the Delaware sachem Keekyuscung had predicted, the presence of English settlers west of the mountains had outraged the local Indians. Pittsburgh storekeeper James Kenny noted that "It Greives ye Indians to see ye White People Settle on these Lands \& follow Hunting or Planting, especially in Virginia side."240 Likewise, Sergeant McDonald stationed just west of present Uniontown, Pennsylvania lamented that "the Indians seems Very much Disturbed and say the white people kills all there deer." ${ }^{, 241}$ The Ohio Iroquois even went so far as to offer a "War Belt and Bloody Tomhock" to the Shawnees in hopes of enlisting their aid "as they are Going to Strike ye English \& drive them off their Lands." ${ }^{242}$ Not surprisingly, the following spring, the Shawnees, Delawares, and Ohio Iroquois joined with the Ottawa war chief Pontiac in a general uprising against British domination. War parties once again struck the pioneer settlements of western Virginia.

The settlers in the Greenbrier Valley suffered a particularly devastating blow in the summer of 1763 when a war party of sixty Shawnees infiltrated the settlements. Under the leadership of Chief Cornstalk, the warriors used a tactic whereby they approached a cabin, feigned friendship, and then attacked by surprise. First turning their attention to the settlers living along Muddy Creek, the Shawnees killed Frederick See and Felty Yocum along with their families. In addition, they took "many others" captive. ${ }^{243}$ According to Withers in his Chronicles of Border

\footnotetext{
${ }^{240}$ James Kenny quoted in Downes, Council Fires on the Upper Ohio, 114.

${ }^{241}$ McDonald to Bouquet, 25 October 1761, Bouquet Papers, series 21647, 175.

${ }^{242}$ James Kenny quoted in Downes, Council Fires on the Upper Ohio, 114.

${ }^{243}$ Stuart, Memoir of Indian Wars, 5; Stuart, "Memorandum, 1798," 368.
} 
Warfare, the Shawnees had divided into smaller bands and "visited" the various cabins simultaneously. ${ }^{244}$ Doing so would have limited the chances of word getting out that an attack was underway.

Cornstalk's warriors then turned their attention toward the settlements at the "Big Levels" located at present Lewisburg. Upon discovering that most if not all of the one hundred or so settlers in the area had assembled for a feast at the home of Archibald Clendenin, the Shawnees apparently approached the cabin as a single large body. Again feigning friendship, the warriors joined in the festivities that included feasting on three elk that Clendenin had just recently killed. Quite possibly, these Shawnees had chanced upon some sort of communal work activity such as a cabin raising. Regardless, the Shawnees eventually ended their charade by killing or capturing all but one of the settlers. The sole escapee, Conrad Yocum, apparently suspecting treachery had left the gathering under the pretense of needing to hobble his horse. Once out of sight, he preserved his life by fleeing eastward across the mountains. ${ }^{245}$

Much like they had a decade earlier, pioneer families throughout western Virginia once again found themselves in a position where they had to decide whether to stay or flee. In the Greenbrier Valley, the possibility of another Indian attack "intimidated" the remaining settlers so much that they abandoned the frontier leaving the area "once more depopulated." 246 Before the

${ }^{244}$ Withers, Chronicles of Border Warfare, 93.

${ }^{245}$ Stuart, Memoir of Indian Wars, 5; Stuart, "Memorandum, 1798," 368; Withers, Chronicles of Border Warfare, 93-94. In his memorandum, Stuart adds that in the course of these attacks, many "cruelities were committed too horid to be related, and too many to be contained in this memorandum."

${ }^{246}$ Stuart, "Memorandum, 1798," 368. 
year 1764 had ended, not a single settler remained on the western Virginia frontier. Efforts to occupy the region had failed twice within a decade.

By the time a tenuous peace returned to the frontier in 1765 following the defeat of Pontiac, a new barrier to settlement had been erected, the Proclamation of 1763 . Issued by the crown on 7 October of that year, the proclamation formalized the policy of restricting contact between the Indians and colonists. Not only did the proclamation reaffirm the ban on settlement west of the Allegheny Mountains, but it also ordered anyone currently living there to immediately "remove themselves." In addition, the proclamation required all Indian traders to be licensed by their governor and to abide by all government trade regulations. It furthermore banned private citizens from purchasing land directly from the Indians. Perhaps in an attempt to make these restrictions more palatable, the proclamation also declared that French and Indian War veterans could apply for land grants as a reward for their military service. The size of the grant varied according to rank with field grade officers being eligible for up to five thousand acres on down to privates who could each receive fifty acres. Nowhere did the proclamation specify where the land was to be located. ${ }^{247}$

Much to the dismay of land speculators, the ban on frontier settlement applied equally to them as well. For many individual speculators who had received their grants prior to the French and Indian War, the ban meant little because their grants had already lapsed. But what about cases where a large land company had already surveyed their land and even sold some of it to families who subsequently abandoned it to escape Indian attacks? Could those families return

${ }^{247}$ Ronald L. Lewis and John C. Hennen, Jr., eds., West Virginia: Documents in the History of a Rural-Industrial State. (Dubuque, Iowa: Kendall Hunt Publishing Company, 1991), 33-35. 
now that peace had been restored? In 1760, Virginia Governor Francis Fauquier posed these questions to the British Board of Trade on behalf of the Greenbrier and Loyal companies. ${ }^{248}$ In a somewhat ambiguous reply, the Board informed the governor that he should do nothing that could "in any degree, have a tendency" to incite the Indians. ${ }^{249}$ In other words, the answer was probably "no." As frustration grew, George Mercer expressed the sentiment of land speculators and settlers alike when he wrote that he would "leave no stone unturned" in his efforts to overcome the settlement ban. ${ }^{250}$

For some people, the solution to the problem was to simply ignore it. By 1767 , for example, at least a dozen frontiersmen had disregarded the proclamation and illegally moved into the watershed of the upper Monongahela River. While some of these men appear to have been hunters such as John Simpson who established a semi-permanent hunting camp along Elk Creek near present Clarksburg, others came as bonafide settlers who built homes and planted crops. ${ }^{251}$ Collectively, these men comprised the vanguard of what would become a third attempt by settlers to occupy the western Virginia frontier.

Somewhat surprisingly, illegal settlement did not occur in the Greenbrier Valley where the

${ }^{248}$ Fauquier to the Board of Trade, 1 September 1760, Journals of the House of Burgesses of Virginia, 1758-1761, eds. Henry R. McIlwaine and John P. Kennedy (Richmond: Colonial Press, 1980), 289; Sosin, Whitehall and the Wilderness, 45.

${ }^{249}$ Quoted in Sosin, Whitehall and the Wilderness, 46.

${ }^{250}$ George Mercer to George Washington, 16 September 1759, Letters to Washington and Accompanying Papers, vol. 3, 1758-1770, ed. Stanislaus Murray Hamilton (Boston: Houghton, Mifflin, 1901), 160.

${ }^{251}$ Earl L. Core, Prelude, vol. 1 of The Monongalia Story: A Bicentennial History (Parsons, W. Va.: McClain, 1976), 163-64; Withers, 118-19; Rice, Allegheny, 65. 
Greenbrier Company maintained vigilance over its land holdings. In addition, the company, along with other powerful speculative interests, also actively lobbied royal officials to reopen western Virginia to settlement. In 1768, their efforts came to fruition when the home government instructed Sir William Johnson and John Stuart, the Indian superintendents for the northern and southern districts respectively, to negotiate land cessions in western Virginia with the Iroquois and Cherokee who both claimed ownership of the land. Although the British secretary of state had authorized only a limited land transfer in order create a reserve for Virginia's French and Indian War veterans, the Indian superintendents succumbed to the influence of speculators and negotiated land cessions that vastly surpassed what had been authorized. Out of their negotiations with the Indians emerged two important agreements, the Fort Stanwix Treaty of 1768 with the Iroquois and the 1768 Treaty of Hard Labor with the Cherokee. By adjusting the proclamation line westward to the Ohio River, the treaties reopened almost all of present West Virginia to white settlement. ${ }^{252}$

In the spring of 1769 , settlers began streaming across the Allegheny Mountains. While there is no way of determining precisely what the frontier population may have been, the number appears to have been in the thousands by the outbreak of the Revolutionary War in 1775. Unfortunately, there are no census records or tax lists for the 1770s. Other documents, however, do provide a glimpse into what the population may have been. The account books of the George and Sampson Matthews trading post located in the Greenbrier Valley, for example, list 401

${ }^{252}$ Otis K. Rice, A History of Greenbrier County (Lewisburg, W. Va.: Greenbrier Historical Society, 1986), 28-30. Note, the John Stuart who served as an Indian superintendent is not the same John Stuart who settled in the Greenbrier Valley in 1769 and became a prominent local official. 
different frontiersmen who made transactions there from 1771 through $1774 .^{253}$ In looking at those names, it can safely be said that many of the predominately male customers headed local pioneer families. Furthermore, it is doubtful that every resident of the Greenbrier Valley had an account at that particular trading post. Thus, it is quite possible that by 1775 , two thousand or more people resided in the Greenbrier Valley area. While there are no similar trading post account books for the upper Monongahela Valley section of western Virginia, a 1777 military dispatch from Colonel Zackwell Morgan, the future founder of Morgantown, to General Edward Hand at Fort Pitt mentioned having assembled about five hundred men to fight Indians and suppress a loyalist uprising. ${ }^{254}$ If Morgan had access to five hundred militiamen, and knowing that the militia law required practicably every able-bodied man between the ages of sixteen and fifty to serve, then it is reasonable to assume that the pioneer population of the upper Monongahela Valley likewise exceeded two thousand people around the start of the Revolution. ${ }^{255}$ Other sections of western Virginia either had considerably fewer or absolutely no settlers at all by the mid-1770s.

The pioneer population of western Virginia from the earliest days of settlement tended to be quite unevenly distributed. To a great extent, this unevenness can be attributed to two interrelated factors, geography and the existence of an already established network of trails. Long

${ }^{253}$ Frances Alderson Swope, comp., "The Matthews Trading Post Ledger, 1771-1779," Journal of the Greenbrier Historical Society 4, no. 4 (1984), 20-60; Harry E. Handley, "The Matthews Trading Post," Journal of the Greenbrier Historical Society 1 (August 1963): 8-14.

${ }^{254}$ Reuben Gold Thwaites and Louise Phelps Kellogg, eds., Frontier Defense on the Upper Ohio, 1777-1778 (Madison: Wisconsin Historical Society, 1912), 53.

${ }^{255}$ For the age requirements under the militia law of 1777, see Hening, Statutes, 9:267. 
before the arrival of either settlers or Indians, animals such as buffalo and deer created worn paths "plain as roads" that lead from one natural salt lick or pasture to the next. ${ }^{256}$ The Indians, and European settlers, later adopted these paths for their own use. Although dozens of different trails traversed the trans-Allegheny region, a few proved particularly useful to settlers because they served as routes across the rugged Allegheny Mountains. From north to south, the most important of these transmontane trails included Nemacolin's Path a.k.a. Braddock Road, McCullough's Path, and the Buffalo Trace. ${ }^{257}$ (See Map 2)

Once across the mountains, the settlers encountered several rivers that generally flowed in a north-south orientation. These included the Monongahela, Cheat, West Fork, Tygart Valley, and Greenbrier rivers. With printed maps largely unavailable, settlers followed these watercourses and their tributaries not only to aid them in navigating this "continuity of woods without end," but also to lead them straight to the most desirable farm sites situated within the broad fertile flood plains. ${ }^{258}$ In many cases, the preexisting trails paralleled the rivers anyway. ${ }^{259}$

${ }^{256}$ Ben Guthrie Interview, Draper Manuscripts, 11 CC 255, HSW.

${ }^{257}$ For Nemacolin's Path see Paul A. W. Wallace, Indian Paths of Pennsylvania (Harrisburg: Pennsylvania Historical and Museum Commission, 1965), 109-12; For the Buffalo Trace, see Earl E. Berkley, "Where Ancient Trails Once Crossed," Journal of the Greenbrier Historical Society 4, no. 5 (1985): 28-30.

${ }^{258}$ Colonel Henry Bouquet quoted in Fort Ligonier Association et al., War for Empire in Western Pennsylvania (Ligonier, Penn.: Fort Ligonier Association, 1993), 7.

${ }^{259}$ Recall the popular story of Mary Draper Ingles who was taken captive by a Shawnee war party in 1755 near the present city of Blacksburg, Virginia. Planning to escape and return home at some future point in time, she memorized the streams and rivers that paralleled the trails taken by her captors. When she finally did make her escape, she made her way back home by retracing those waterways in reverse order. For an account of her story, see John P. Hale, TransAllegheny Pioneers: Historical Sketches of the First White Settlers West of the Alleghenies (Charleston, W. Va.: Kanawha Valley Publishing, 1931). 
From the Greenbrier Valley, settlers pushed westward down the New River to the Kanawha and Ohio valleys where they established settlements starting in $1773 .{ }^{260}$ A second route to the Ohio Valley involved following the Monongahela River north to Fort Pitt where settlers either bought or built rafts in order to float down the Ohio River. As they descended the Ohio, they established widely scattered homesteads all the way from above present Wheeling to the mouth of the Little Kanawha River. ${ }^{261}$ Some settlers pushed even further downstream eventually reaching the Kanawha Valley and beyond. Thus, by 1773 hundreds of homesteads had been established "along the whole extent of the western frontier. Even the shores of the Ohio."262

Looking back, it had been almost a quarter century since Stephen Sewel and Jacob Marlin built their cabin near the mouth of Knapps Creek in the Greenbrier Valley. Twice during the ensuing twenty-four years, hundreds of settlers had crossed the mountains into western Virginia, selected home sites, cleared the land, built cabins, planted crops, and suffered the terrors of Indian warfare. Encounters with Indians "scarified" settler Archibald Clendenin to the point that "he looked like an old racoon dog." ${ }^{263}$ Perhaps fortunately for him, he died at the hands of a Shawnee warrior shortly before another Indian slammed Clendenin's infant child against a tree until it

${ }^{260}$ Lyman Chalkley, Chronicles of the Scotch-Irish Settlement in Virginia, Extracted from the Original Court Records of Augusta County, 1745-1800 (Baltimore: Genealogical Publishing, 1966), 2:68-69.

${ }^{261}$ Rice, Allegheny Frontier, 67.

${ }^{262}$ Joseph Doddridge, Notes on the Settlement and Indian Wars (reprint; 1912, Parsons, W.Va.: McClain, 1989), 171. The first edition of this book was published in 1824.

${ }^{263}$ James Wade Interview, Draper Manuscripts, 12 CC 12, HSW 
died. ${ }^{264}$ Similar atrocities occurred dozens of times to dozens of different families as Iroquois, Shawnee, Delaware, and Ottawa, warriors robbed, attacked, and/or killed anyone who dared venture across the Allegheny Mountains. One's nationality, race, religion, social standing, or even overt friendship toward the Indians offered no guarantee of immunity from the violence. Only by abandoning a homestead and fleeing eastward across the mountains could a settler significantly improve the chances of retaining his scalp.

During the early 1770 s, Indian warfare must have appeared like a thing of the past to the hundreds of frontiersmen streaming over the mountains bringing with them wives, children, plans, and dreams of a better future. Perhaps they had been lulled into a false sense of security by the seven years of relative peace that had prevailed following the defeat of Pontiac. Maybe they believed God would protect them from harm. Or quite possibly, poverty and a lack of opportunity in the east had left them no alternative but to move to the frontier in spite of the potential dangers. Regardless, little could anyone realize that the Indian wars had not come to an end. In fact, hostilities between the Indians and the Virginians would continue for another two decades with only brief interludes of peace. Not until 1795 would most of the Ohio Indians reluctantly lay down their arms with the signing of the Greenville Treaty. In the meantime, the hostilities, bloodshed, and frontier living conditions would continue.

\footnotetext{
${ }^{264}$ Stuart, "Memorandum, 1798," 368.
} 


\section{Chapter Five}

Producing for the Household and Market

In his study of the Shenandoah Valley frontier, Robert Mitchell drew a connection between the duration of the frontier experience and the household economies of the settlers. ${ }^{265}$ By considering factors such as living standards, household production, self-sufficiency, commercialism, and degree of isolation from established markets, the settlers' households, in a way, functioned as indicators of the overall state of that particular frontier. Valuable insight into the character of the frontier experience can be gained by understanding how the settlers provided for their daily household needs. Over the course of this chapter, we will see that despite disadvantages such as rugged terrain, long distances from eastern markets, and inadequate transportation networks, the people who settled trans-Allegheny Virginia not only managed to provide for their own household subsistence, but in many cases they also produced surpluses that could be exchanged on the commercial market.

Before embarking on an analysis of the pioneer household economy, it would be beneficial to define a few of the economic terms as used in this study.

"Subsistence economics" involves the production of goods and services for the express consumption of the producers and their families. Involvement with the marketplace is very limited and plays a minor role in meeting the family's material requirements. ${ }^{266}$ Hunting wild game or

${ }^{265}$ Robert D. Mitchell, Commercialism and Frontier: Perspectives on the Early Shenandoah Valley (Charlottesville: University Press of Virginia, 1977), 3.

${ }^{266}$ Arthur Getis, Judith Getis, Jerome D. Fellmann, Introduction to Geography, 6th ed. (Boston: McGraw-Hill Higher Education, 1998), 355-58, 526. 
gathering chestnuts to feed one's family are examples of subsistence activities. Additionally, building one's own log cabin or spinning and weaving linsey-woolsey to clothe one's children also falls within the realm of subsistence economics.

"Commercial economics" is the production of goods and services destined for exchange in the competitive market. The principle of supply and demand is in effect. ${ }^{267}$ Bartering deerskins at a trading post or selling agricultural products at a county market are examples of commercial activities.

"Capitalism" is a particular type of commercial economic production in which workers neither own the means of production nor do they have a share in the goods or services they produce. As compensation for their labor, the workers receive a wage. In capitalist economics, labor is considered to be a commodity. ${ }^{268}$ An example of backcountry capitalism can be seen in the glass factory built by Albert Gallatin in 1794. In addition to employing a bookkeeper and clerk, he also hired six German glass workers to operate his facility. ${ }^{269}$ In contrast, a blacksmith with a backyard shop who sells hand-forged nails directly to his neighbors is not involved in a capitalist enterprise because he owns his own tools, the goods he produces, and works for himself. On the other hand, if that same blacksmith expanded his operation by hiring additional smiths to work in his shop under his direction, the shop would then become involved in capitalist production.

${ }^{267}$ Getis, Getis, and Fellmann, Introduction to Geography, 355-56, 516.

${ }^{268}$ Maurice Dobb, Studies in the Development of Capitalism (New York: International Publishers, 1947), 7-8, 10.

${ }^{269}$ Franklin Ellis, History of Fayette County (Philadelphia: L. H. Everts, 1882), 768-69. 
As an aid to understanding the structure of the settlers' household economies, the idea of "competency" is employed as a theoretical model. In the early modern period, the term competency referred to a comfortable standard of living somewhat above the level of mere survival. ${ }^{270}$ The Oxford English Dictionary defines the term as "a sufficiency, without superfluity, of the means of life . . a sufficient income; easy circumstances."271 Unlike fully developed capitalism, the pursuit of competency does not involve the endless accumulation of wealth. ${ }^{272}$ Rather, when a family has achieved a competent standard of living, the desire to continue working diminishes. For example, William Wood observed in 1634 that despite the crudeness of life in New England, the colonists seemed "well-contented, and looke not so much at abundance, as a competencie., 273

Competency did not connote a uniform standard that everyone aspired to achieve. People differed in what they considered a competent lifestyle to be. ${ }^{274}$ An educated backcountry entrepreneur such as future United States Secretary of the Treasury Albert Gallatin aspired to a higher level of comfort and refinement than a professional hunter such as Meshach Browning.

${ }^{270}$ Daniel Vickers, "Competency and Competition: Economic Culture in Early America," The William and Mary Quarterly 47 (January 1990): 3-4.

${ }^{271}$ The Oxford English Dictionary, 2d ed., s.v. "competency."

${ }^{272}$ Rex Burns, Success in America: The Yeoman Dream and the Industrial Revolution (Amherst: University of Massachusetts Press, 1976), 1.

${ }^{273}$ Vickers, "Competency and Competition," 3, 12. See also Andrew R. L. Cayton, "Marietta and the Ohio Company," in Appalachian Frontiers: Settlement, Society, and Development in the Preindustrial Era, ed. Robert D. Mitchell (Lexington: University Press of Kentucky, 1990), 194-95.

${ }^{274}$ Vickers, "Competency and Competition," 3. 
The difference in their concept of competency is evidenced by their homes. While Gallatin's home consisted of a multi-story stone manor house named Friendship Hill, Browning opted to live in a log cabin that "had neither floor, chimney, nor door - a hole cut through the wall being the only way of getting in or out."275 Socioeconomic class, education level, occupation, family responsibilities, reputation, societal expectations, and personal preference all helped to determine a person's concept of competency.

By no means did a person's sense of competency necessarily remain static over the course of his life. Changing circumstances frequently caused people to reassess what they believed was necessary to achieve competency. ${ }^{276}$ For example, the material requirements of settler Jacob Prickett changed between 1772 and 1790 when he went from having thirteen people in his household to being a sixty-eight year old widower with adult children. ${ }^{277}$ Social mobility also influenced competency. In 1784, the Harrison County Court appointed settler William Haymond, Sr., to the position of county surveyor. Prior to assuming his new post, Haymond was required to pass a qualifying exam at William and Mary College. In preparation for his trip to Williamsburg, he bought a new coat that made him "proud, as no other person had one" like it. ${ }^{278}$ His purchase of the coat can be interpreted as an outward manifestation of his rising sense of what constituted a competency. As a frontiersman, Haymond's old coat probably sufficed, but when he became an

${ }^{275}$ Minnie Kendall-Lowther, Friendship Hill: Home of Albert Gallatin (Morgantown, W. Va.: Friendship Hill Association, 1928); Meshach Browning, Forty-Four Years of the Life of a Hunter (Winston-Salem, N. C.: Winston Printing Company, 1942), 103.

${ }^{276}$ Vickers, "Competency and Competition," 3.

${ }^{277}$ J. Miles Prickett Papers, PFMFA.

${ }^{278}$ Haymond to Haymond, 18 February 1842, William Haymond, Jr., Papers, WVRHC. 
important county official he likely perceived a need to wear clothing commensurate to his elevated social status.

Seeking a competency did not preclude commercial endeavors. After all, competency is not synonymous with subsistence. As we will see, when the settlers looked for ways to achieve their competencies, they employed both subsistence and commercial modes of economic production. In many cases, a particular resource had value not only within the household, but also on the commercial market. Comparative historian Paul Salstrom pointed out that "no contradiction existed between market farming and ... subsistence farming." Livestock and grain, for example, "were just as suitable for supplying outside markets as they were for home consumption. ${ }^{279}$ By the same token, forest products, such as deerskins, could also be used either domestically or sold on the commercial market. In short, competency is best envisioned as an economic objective while commercial and subsistence modes of production are merely means of achieving that end.

One of the limiting factors in how people pursue their competencies is the availability and types of natural resources. Fortunately for the settlers, upon crossing the threshold of the Allegheny Mountains into western Virginia, they encountered a land abundant in the necessities of life. Save for a scattering of mountain glades and old Indian fields in varying stages of regrowth, a vast forest of tall straight trees completely covered the hills and mountains of the region. ${ }^{280}$

${ }^{279}$ Paul Salstrom, Appalachia's Path to Dependency: Rethinking a Region's Economic History, 1730-1940 (Lexington: University Press of Kentucky, 1994), xiv; Paul Salstrom, "Subsistence-Barter-and-Borrow Systems: An Approach to West Virginia's Economic History," West Virginia History, 51 (1992): 46.

${ }^{280}$ Earl Core, Vegetation of West Virginia (Parsons, W. Va.: McClain, 1966), 49. 
Within the forest lived a diversity of animal life including white-tailed deer, elk, black bears, turkeys, mountain lions, beavers, gray wolves, and even small herds of buffalo. ${ }^{281}$ The land supported an abundance of native edible plants such as strawberries, blackberries, chestnuts, walnuts, hickory nuts, paw paws, service berries, wild plums, wild grapes, wild cherries, ramps, and the syrup producing sugar maple. ${ }^{282}$ The nutrient-rich soil, particularly in the river and creek bottomlands, proved to be conducive to mixed agriculture and livestock grazing. ${ }^{283}$ Beneath the surface of the ground lay rich mineral resources, such as coal, oil, limestone, clay, sand, iron ore, and salt. ${ }^{284}$ European settlers, much like the Indians who had first settled the region thousands of years earlier, found western Virginia to be a hunter gatherer's paradise.

The pioneers frequently mentioned the economic potential of this new land in their writings. In 1671, Thomas Batts and Robert Fallom crossed the Allegheny Mountains exploring as far west as Tug Fork near the present city of Matewan, West Virginia. ${ }^{285}$ In his short journal, Fallom referred to the quality of the soil no fewer than seven times. Near the Blue Ridge in eastern Virginia, he found "very stony rocky ground," however, by the time the expedition had

${ }^{281}$ On buffalo in West Virginia, see Stanley W. Baker, "Evidence of Bison in the Aboriginal Arts and Cultural Record of the Upper Ohio Valley," West Virginia Archeologist 50 (Spring \& Fall 1998): 29.

${ }^{282}$ Joseph Doddridge, Notes on the Settlement and Indian Wars (1912: reprint, Parsons: W. Va.: McClain, 1976), 70-75.

${ }^{283}$ L. Diane Barnes, “Avenues to a Market Economy: Harrison County, West Virginia, to 1860” (Master's thesis, West Virginia University, 1995), 3, 10-11.

${ }^{284}$ Michael E. Workman, "Political Culture and the Coal Economy in the Upper Monongahela Region: 1776-1933” (Ph.D. diss., West Virginia University, 1995), 52-53.

${ }^{285}$ Alan Vance Briceland, Westward from Virginia: The Exploration of the VirginiaCarolina Frontier, 1650-1710 (Charlottesville: University Press of Virginia, 1987), 134, 144. 
reached Tug Fork, the soil was "very rich.”286 Settler Joseph Doddridge similarly noted that throughout western Virginia, "a fruitful soil . . supplies abundantly all the wants of life."287 Other pioneers noticed the commercial value of the timber. Writing in his journal in 1746, surveyor Thomas Lewis described the hills as being exceedingly well timbered. The spruce, cherry, beech, and maple trees were "the most and finest" he had ever seen with some being "three or four feet Diameter thirty or forty foot without a Branch.",288 Settlers, explorers, and speculators alike looked upon the abundance of land and resources as an opportunity for material gain.

Most of the people who settled in "West Virginia" during the final third of the eighteenth century came from eastern Virginia, Pennsylvania, New Jersey, and Maryland with smaller numbers originating in New England and overseas. ${ }^{289}$ While much has been written on the migration patterns followed by these settlers, several important points merit reiteration. First, many of the settlers that moved to western Virginia during the final third of the eighteenth century had been born and raised in America. Second, when settlers moved west, they often did so as part of a larger extended kinship group. ${ }^{290}$ Third, frontier zones exhibited high degrees of

${ }^{286}$ [Robert Fallam], "Explorations Beyond the Mountains," The William and Mary Quarterly 15 (April 1907): 236-40.

${ }^{287}$ Doddridge, Notes on the Settlement, 21.

${ }^{288}$ Thomas Lewis, The Fairfax Line: Thomas Lewis' Journal of 1746 (New Market, Va.: Henkel Press, 1925), 39.

${ }^{289}$ Otis K. Rice, The Allegheny Frontier: West Virginia Beginnings, 1730-1830 (Lexington: University Press of Kentucky, 1970), 65.

${ }^{290}$ Ellen Eslinger, "Migration and Kinship on the Trans-Appalachian Frontier: Strode's Station, Kentucky," Filson Club Quarterly 62 (January 1988): 52-53, 65; Elizabeth A. Perkins, 
mobility including immigration, emigration, and through migration. ${ }^{291}$ And fourth, when settlers moved west, they brought along with them their cultural heritage including attitudes and knowledge pertaining to agriculture, commerce, and techniques of managing one's household economy. Considering that settlers in western Virginia tried to use the same methods of agriculture that had proven so successful in the Shenandoah Valley, ${ }^{292}$ it would be beneficial to briefly consider the domestic economy of the Valley so as to gain some insight into the economic background of the settlers who came to western Virginia.

Agriculture formed the basis of the Shenandoah Valley economy throughout the eighteenth century. But unlike eastern Virginia where farming tended to be dominated by tobacco cultivation, the majority of farmers in the Valley practiced a diversified style of agriculture with the four most important crops being wheat, corn, rye, and flax. Other prominent crops included barley, oats, hemp, and tobacco. Farmers sometimes cultivated small amounts of buckwheat, but it failed to become an important crop in the region. At the same time, efforts to cultivate cotton never went beyond the experimental stage.

Most farmers in the Shenandoah Valley also raised a variety of fruits and vegetables. While the Indians had raised some species, such as pumpkins, squash, and beans, others had been brought from Europe including peas, cucumbers, radishes, cabbages, carrots, spinach, and parsnips. Settlers also grew white potatoes and turnips not only for human consumption, but also

Border Life: Experience and Memory in the Revolutionary Ohio Valley (Chapel Hill: University of North Carolina Press, 1998), 112-13.

${ }^{291}$ Mitchell, Commercialism and Frontier, 45-54.

${ }^{292}$ Barbara Rasmussen, Absentee Landowning and Exploitation in West Virginia, 17601920 (Lexington: University Press of Kentucky, 1994), 5. 
as feed for farm animals. Common fruit trees included apples, peaches, and cherries. Beyond consuming the fruit fresh, farmers also dried some for future use and converted the rest into cider or brandy. ${ }^{293}$

In addition to vegetable crops, almost every farmer raised a variety of livestock including cattle, horses, sheep, and hogs. Most of these animals free-ranged feeding on wild grasses, leaves, and mast. Although some Valley farmers used teams of oxen to pull wagons and plows, the majority of farmers preferred to use horses. Chickens and geese provided eggs, meat, and downy feathers on almost every farm while ducks, although present, showed up much less often. Some farmers even maintained hives of honeybees as a source of sweetener and beeswax. ${ }^{294}$

Although most farmers used the majority of their farm products to provide for their own subsistence, very few lived an entirely self-sufficient existence. ${ }^{295}$ After all, people need more than just food to enjoy a competency. They also require shelter, clothing, tools, luxury items, and professional services. In many instances, farmers simply lacked the ability to produce a necessary item either at all or in sufficient quantities. Consider rural eastern Pennsylvania farmers who like their Shenandoah Valley counterparts also practiced a diversified style of agriculture. ${ }^{296}$ Despite having an agrarian-based economy, Pennsylvania farmers simply did not produce enough wool

${ }^{293}$ Mitchell, Commercialism and Frontier, 136-39; James T. Lemon, The Best Poor Man's Country: A Geographical Study of Early Southeastern Pennsylvania (Baltimore: Johns Hopkins Press, 1972), 158; Dorothy Hartley, Lost Country Life (New York: Pantheon Books, 1979), 346; Sarah F. McMahon, "A Comfortable Subsistence: The Changing Composition of Diet in Rural New England, 1620-1840,” The William and Mary Quarterly 42 (January 1985): 39-41.

${ }^{294}$ Mitchell, Commercialism and Frontier, 139-40.

${ }^{295}$ Mitchell, Commercialism and Frontier, 152.

${ }^{296}$ Lemon, Best Poor Man's Country, 151-57. 
and flax to supply all of their domestic textile needs. An analysis of household inventories from the second half of the eighteenth century reveals that about fifty percent of Pennsylvania households owned no sheep, sixty percent had no flax, and eighty percent possessed no wool or yarn. In addition, many households also lacked the tools needed to process fiber into cloth. Approximately thirty percent of households had no spinning wheels and at least ninety percent lacked a loom. To compensate for their inability to meet their domestic textile requirements, Pennsylvanians purchased large quantities of cloth imported from the British Isles. ${ }^{297}$ Farmers living in the Shenandoah Valley did likewise. Although they did produce linen and woolen cloth, it tended to be quite course, hence the vigorous local demand for imported higher quality textiles such as osnaburg, silk, check, and Irish linen. In addition, they also imported ready made clothing particularly hats, shoes, coats, and breeches. In other words, farmers living in the Shenandoah Valley depended on the commercial market to achieve a competency. ${ }^{298}$

Participation in the commercial market required Shenandoah Valley farmers to produce marketable surpluses. The most frequently sold farm products included wheat, tobacco, whiskey, cider, tallow, cheese, butter, animal hides, and thread. By the mid-1760s, some farmers had even begun to specialize in commercial crops. These commercial specialties consisted primarily of wheat, hemp, and tobacco, with much smaller amounts of indigo also being grown. It is estimated that by about 1765 , approximately twenty-five percent of the typical valley farmer's total agricultural output consisted of marketable surpluses. Thus, by the eve of the Revolutionary War,

${ }^{297}$ Adrienne D. Hood, "The Material World of Cloth: Production and Use in EighteenthCentury Rural Pennsylvania," The William and Mary Quarterly 53 (January 1996): 52-53; Lemon, Best, 27.

${ }^{298}$ Mitchell, Commercialism and Frontier, 153. 
farmers living in the Shenandoah Valley had come to rely on both subsistence and commercial modes of production in order to achieve their competencies. ${ }^{299}$

When settlers moved west across the Allegheny Mountains to the frontier during the early 1770s, they tried to use the same economic strategies that had worked so well for them in the Shenandoah Valley and eastern Pennsylvania. From the outset, however, many settlers found it difficult to attain the same levels of competency they had known in the East. There is a long list of basic reasons why a competent lifestyle proved so elusive. First, the heavily forested landscape made it virtually impossible for the earliest settlers to farm with plows and other horse-drawn equipment. Second, the established commercial centers at Winchester and Staunton lay over a hundred miles to the east in the Shenandoah Valley. Third, the high ridges of the Allegheny Mountains initially prevented the use of wagons in conducting commerce with eastern Virginia. Fourth, the rugged mountainous landscape limited the availability of level farmland thus ensuring that the region would have a relatively low population density. This in turn hindered economic development by limiting the size of the local market, the county tax base, and the number of people available for work on the roads. Fifth, the region lacked a regular army staging area, such as Fort Pitt or Winchester, that might have promoted local economic development. And sixth, starting in the spring of 1774 , the region would experience two decades worth of disruptive Indian-related violence and warfare. Collectively, all of these factors played a part in hindering the pursuit of competency in the region during the 1770s and 1780s.

Perhaps the most immediate problem encountered by the earliest trans-Allegheny settlers revolved around the fact that they had left behind convenient access to the commercial market

\footnotetext{
${ }^{299}$ Mitchell, Commercialism and Frontier, 152, 156-57, 181-83.
} 
including stores, artisan's shops, and county fairs. Settlers who re-occupied the Greenbrier Valley in 1769, for example, had to wait until 1771 before brothers Sampson and George Mathews established a local trading post. ${ }^{300}$ In the upper Monongahela Valley, settlers waited even longer before Thomas Laidley opened a local store circa 1783 at present Morgantown. ${ }^{301}$ During the interval between initial settlement and the establishment of stores, many pioneer families looked toward the older commercial centers of the Shenandoah Valley as places to obtain tools, supplies, and luxury items. ${ }^{302}$ Towns such as Winchester and Staunton offered practically every material object a trans-Allegheny settler might require. The account books of Colonel James Wood of Winchester provides insight into the variety of commercially available goods including salt, sugar, black pepper, shoes, cloth, lead, black powder, and slaves. ${ }^{303}$ Pioneer farmers could also purchase farming tools, seed for planting, and breeding livestock. Particularly ambitious settlers could even purchase a hive of honeybees to carry back across the mountains. ${ }^{304}$ This continued access to the older commercial centers in the Shenandoah Valley allowed the settlers of western Virginia to avoid being cast into complete self-sufficiency.

${ }^{300}$ Frances Alderson Swope, comp., "The Mathews Trading Post Ledger, 1771-1779," Journal of the Greenbrier Historical Society 4, no. 4 (1984): 20.

${ }^{301}$ Haymond to Haymond, 18 February 1842, William Haymond, Jr. Papers, WVRHC; Earl L. Core, The Pioneers, vol. 2 of The Monongalia Story: A Bicentennial History (Parsons, W. Va.: McClain, 1976), 98.

${ }^{302}$ Doddridge, Notes on the Settlement, 96-97.

${ }^{303}$ Extracts from the account books of Colonel James Wood are located in Frederic Morton, The Story of Winchester in Virginia: The Oldest Town in the Shenandoah Valley (Strasburg, Va.: Shenandoah Publishing House, 1925), 56-57.

${ }^{304}$ Morton, Story of Winchester, 58-59. 
But just because settlers could reach the Shenandoah Valley did not mean that it was convenient or easy. Interposed between the western settlements and the Shenandoah Valley were the Allegheny Mountains, a twenty-mile or wider series of high parallel ridges generally oriented in a northeast to southwest direction. With many individual peaks reaching over three thousand feet in elevation and few natural gaps, crossing the mountains could be quite difficult. ${ }^{305}$ The journals and letters of eighteenth century travelers are filled with accounts of the hardships involved in traversing the mountains. In the summer of 1790, for example, Methodist circuit rider Richard Whatcoat crossed from the Greenbrier Valley into the upper Monongahela Valley on "As Ruf a Road" as he had ever traveled. ${ }^{306}$ Settler David Crouch who lived in the Tygart Valley said "We were about fifty miles from the South Branch [of the Potomac]. We had five mountains to cross in going there, that were so steep, a horse could hardly carry a man over them. Never a wagon could get to the South Branch then."307 Other writers lamented the mountain's steep slopes, downed trees, creeks, rivers, dangerous fords, mud, poorly blazed trails, absence of inns, deep mountain snows, and the "danger of being plucked off our horses by the boughs of the trees under which we had to ride." ${ }^{308}$ Perhaps traveler Samuel Allen said it best when he summarized

${ }^{305}$ Oscar Doane Lambert, West Virginia and Its Government (Boston: D.C. Heath, 1951), 5; Rice, Allegheny, 4.

${ }^{306}$ Richard Whatcoat, "The Journal of Bishop Richard Whatcoat, August 1, 1789 December 31, 1790," in The Methodists, vol. 4, Religion on the American Frontier, 1783-1840: A Collection of Source Materials, ed. William Warren Sweet (Chicago: University of Chicago Press, 1946), 108.

${ }^{307}$ David Crouch Interview, Draper Manuscripts, 12 CC 225-26, HSW.

${ }^{308}$ Francis Asbury, The Journal: 1771 to 1793, vol. 1, The Journal Letters of Francis Asbury (London: Epworth Press, 1958), 546. 
his experience in the mountains as simply "most horrid." 309

The ruggedness and poor condition of the mountain trails precluded the use of farm or freight wagons until after the Revolutionary War when the settlers upgraded some of their trails into wagon roads. Prior to these improvements, settlers desiring supplies from the East often used packhorses to transport goods across the mountains. Not surprisingly, trips to the Shenandoah Valley tended to be infrequent due to the difficulty of the journey. Settler David Crouch recalled how "Once a year my father would send in to the South Branch and get two/three bushels ( $80 \mathrm{lb}$. to a bushel) of salt. That would last us a year, packed it over on horses." ${ }^{310}$ George Washington while on a trip across the mountains in September 1784 encountered "numbers of Persons and Pack horses going" east to obtain "Salt and other articles at the Markets" of Maryland and eastern Virginia. ${ }^{311}$ Even the wrought iron used by blacksmiths and farriers had to be brought across the mountains by horseback during the 1770s and $1780 \mathrm{~s} .{ }^{312}$

Sometimes in the fall of the year, neighbors assembled their packhorses into a single pack train to be lead by a master driver with the assistance of some young boys. Many of these caravans averaged ten to fifteen horses with each animal being capable of transporting about two hundred pounds of freight. On the way east, the horses carried furs, ginseng, farm products, and food for both horses and drivers. After reaching their destination and selling their goods, the pack

${ }^{309}$ Samuel Allen quoted in Core, Pioneers, 249.

${ }^{310}$ David Crouch Interview, Draper Manuscripts, 12 CC 226, HSW.

${ }^{311}$ Diary GW, 2: 289.

${ }^{312}$ Arthur Cecil Bining, Pennsylvania Iron Manufacturing in the Eighteenth Century (Harrisburg: Pennsylvania Historical Commission, 1938), 62-63. 
train returned laden with salt, iron, cookware, and anything else that the contributors to the caravan may have requested. ${ }^{313}$ Through the use of annual pack trains, the settlers in western Virginia managed to maintain a tenuous link with the external commercial market.

With commercially produced goods not always readily available, the first settlers had little choice but to shift the focus of their household production in favor of subsistence activities. When necessary, they could sustain a very basic level of competency from the natural resources at hand. Consider, for example, the need for shelter. A shortage or absence of local saw mills made it difficult for the first settlers to construct the wooden-framed homes typical of cismontane farms. ${ }^{314}$ Even without sawmills, some families could have used whipsaws and pit saws to produce about one hundred linear feet of boards per day. ${ }^{315}$ It would appear, however, that the sheer amount of required labor combined with the immediate need for a home tended to discourage the practice. Likewise, settlers in western Virginia tended to avoid building their homes out of fieldstones due to its excessive weight and high cost in terms of time and labor. ${ }^{316}$ Besides that, many settlers would not have possessed sufficient masonry skills to construct something as elaborate as a stone house even if they had wanted to.

${ }^{313}$ Doddridge, Notes on the Settlement, 96-97; James Morton Callahan, Semi-Centennial History of West Virginia (Charleston, W. Va.: Semi-Centennial Commission of West Virginia, 1913), 49. 1982), 33.

${ }^{314}$ Rhys Isaac, The Transformation of Virginia, 1740-1790 (New York: W. W. Norton,

${ }^{315}$ John Morgan, "Log House Construction in Blount County, East Tennessee," in Appalachian Frontiers: Settlement, Society, and Development in the Preindustrial Era, ed. Robert D. Mitchell (Lexington: University Press of Kentucky, 1990), 212-13. 148.

${ }^{316}$ Charles McRaven, Building with Stone (Pownal, Vt.: Garden Way Publishing, 1989), 
Not surprisingly, most settlers in trans-Allegheny Virginia favored logs as a building material. Swedes, Finns, and German settlers from Silesia, Bohemia, and Moravia carried the practice and knowledge of horizontal log construction with them from Europe to Delaware and eastern Pennsylvania where it soon spread to the Shenandoah Valley during the mid-eighteenth century. By that point, the practicality of building with logs had diffused to virtually every cultural group living within the forests of eastern North America. ${ }^{317}$ One of the advantages of constructing a house out of logs was that the builder required few tools beyond a felling axe, broad axe, adz, froe, ${ }^{318}$ crosscut saw, auger, hammer, and perhaps a chisel or hand plane. An additional advantage of building with logs is that an entire log cabin could be built with relative ease in less than a week provided that the family had neighbors willing to lend a hand. ${ }^{319} \mathrm{~A}$ communal log cabin raising provided settlers with a welcome opportunity to socialize with friends, neighbors, and extended family members.

During the earliest years of permanent settlement, people sometimes found themselves in the unfortunate position where they simply had no close neighbors or friends to help them build their homes. Although the settlers' cabins tended to be small, it still took time for a family working alone to complete all of the required preliminary work. Even before a single log could be put into place, the site had to be prepared, trees had to be felled and cut to length, the bark had to be peeled, and the logs needed to be hewn flat on two opposite sides with a broad axe. Only then

${ }^{317}$ Fred Kniffen and Henry Glassie, "Building in Wood in the Eastern United States: A Time-Place Perspective,” Geographical Review 56 (January 1966): 59.

${ }^{318} \mathrm{~A}$ froe is a hand tool used in conjunction with a wooden mallet to split wooden shingles from a large block of wood. Webster's Ninth New Collegiate Dictionary, s. v. "froe."

${ }^{319}$ Doddridge, Notes on the Settlement, 106-8. 
would a horse be used to skid the logs to the construction site. If time permitted, the home builder then stacked the freshly hewn logs and allowed them to partially season so as to limit warping. ${ }^{320}$

While performing this preliminary work, new families on the frontier often lived in crude temporary structures. One family, for example, spent an entire summer living in a hut formed by leaning pine boughs against the face of a cliff. ${ }^{321}$ A few creative settlers, such as John and Samuel Pringle, found temporary shelter within the trunks of large standing hollow trees. ${ }^{322}$ Settlers also sometimes lived in caves or rock overhangs that they referred to as "rock castles.",323 More typically, however, pioneer families and resided in temporary half-faced shelters as they worked on their cabins. A half-faced shelter usually appeared as a large wooden lean-to with an open front, earth or tree bark floor, and animal hides, blankets, or sheets of tree bark as a roof. A large fire pit located directly in front of the open face could be used for heating, cooking, and provided light after sunset. During particularly inclement weather, settlers hung blankets or animal skins across the open front to provide additional protection against wind and rain. ${ }^{324}$ Although there

${ }^{320}$ Charles McRaven, Building and Restoring the Hewn Log House, 2d ed. (Cincinnati: Betterway Books, 1994), 1, 13, 15.

${ }^{321}$ J. E. Wright and Doris S. Corbett, Pioneer Life in Western Pennsylvania (Pittsburgh: University of Pittsburgh Press, 1940), 42.

${ }^{322}$ Henry Haymond, History of Harrison County West Virginia (Morgantown, W. Va.: Acme, 1910), 19; Rice, History, 17.

${ }^{323}$ Ted Franklin Belue, The Long Hunt: Death of the Buffalo East of the Mississippi (Mechanicsburg, Pa.: Stackpole Books, 1996), 88.

${ }^{324}$ John Heckewelder, The Travels of John Heckewelder in Frontier America, ed. Paul A. W. Wallace (Pittsburgh: University of Pittsburgh Press, 1985), 351; In 1820, watercolor artist Fleury Generelly painted a picture of a Shawnee hunter at a half-faced shelter. For a copy of this 
are a few instances of settlers dwelling in a half-faced shelter throughout the winter months, frontiersmen more typically used them during milder weather. ${ }^{325}$

Log houses built in western Virginia tended to be small structures with few amenities. The Reverend Francis Asbury in 1782 described how when traveling through the region he often slept in the woods rather than "lodge in the same room" with a family in their crowded one room cabin. At one point when he did sleep indoors, he described it as "Three thick - on the floor such is our lodging - but no matter: God is with us." ${ }^{326}$ Packed earth often served as the cabin floor and settlers sometimes used greased rawhide in lieu of window glass. ${ }^{327}$ Some of the more austere cabins even lacked fireplaces and chimneys. ${ }^{328}$ In these cases, the occupants built their cooking and heating fires directly on the dirt floor with the smoke escaping through a hole in the roof. Settler Joseph Doddridge reported that many log structures on the trans-Allegheny frontier lacked even a single piece of iron hardware because "such things were not to be had.",329 Wooden pegs called "trunnels" (tree nails) could be used instead of nails while door hinges were fashioned from either wood or strap leather. ${ }^{330}$ In short, through the use of a few simple hand tools, the settlers frequently constructed their homes totally from the natural materials at hand.

painting, see Janet Hubbard-Brown, The Shawnee (New York: Chelsea House Publishers, 1995), 17.

\footnotetext{
${ }^{325}$ William Champ Interview, Draper Manuscripts, 15 C 31, HSW.

${ }^{326}$ Asbury, Letters of Francis Asbury, 1: 42, 463.

${ }^{327}$ Wright, Pioneer Life, 43.

${ }^{328}$ Browning, Life of a Hunter, 103.

${ }^{329}$ Doddridge, Notes on the Settlement, 94.

${ }^{330}$ McRaven, Hewn Log House, 16, 20.
} 
Like their homes, many settlers also manufactured their own clothing through subsistence production. Although stores in the Shenandoah Valley and trading posts in western Virginia stocked various textiles and ready-made clothing, many settlers could not spare the cash that they needed for paying taxes. ${ }^{331}$ Consequently, people typically either manufactured a particular article of clothing at home or simply went without. Consider the case of settler Jacob Parkhurst who as a child lived along Ten Mile Creek in present Washington County, Pennsylvania. He explained that growing up, he and his twin brother wore clothing made of tow linen or deerskins. Until he reached the age of about ten, he "had to do with one long shirt a year," but when it wore out, he "had to go naked, or nearly so, till the next crop of flax was manufactured into linen." 332 During the "hard winter" of 1780, Parkhurst explained that

the snow fell early ... but we had not our new shirts yet; therefore, the twin boys were nearly naked. I began to contrive for myself and accordingly I found a small deer skin ... . so I put strings to it, turned the hair side next to my belly and wore it as an apron. Then I was well prepared to face the winter winds, my feet and legs still naked, and my old shirt gone except for the collar and a few threads hanging around. ${ }^{333}$

Even adults at times suffered from a lack of adequate clothing, particularly footgear. In June 1794, for example, itinerant minister Henry Smith preached to a backwoods congregation near present Fairmont. Looking over his audience, Smith "saw one old man who had shoes on his feet" and one man who "wore Indian moccasins." Everyone else had come to the worship service barefooted. ${ }^{334}$ Considering that it required only a couple of hours to make a pair of moccasins,

\footnotetext{
${ }^{331}$ William Scripps quoted in Haymond, History of Harrison County, 272.

${ }^{332}$ Jacob Parkhurst quoted in Core, Pioneers, 30.

${ }^{333}$ Jacob Parkhurst quoted in Core, Pioneers, 54.

${ }^{334}$ Henry Smith quoted in Core, Pioneers, 229-30.
} 
modern readers might wonder why more members of the congregation did not wear them. Once again, Doddridge provides insight into this issue by describing how moccasins wore out so quickly that patching them "was a labor of almost every evening" and that in wet weather they offered so little protection that they were considered by many to be little more than "a decent way of going barefooted." 335

Even prominent citizens in the backcountry settlements sometimes owned only minimal amounts of quality clothing. When Colonel Zackwell Morgan died in 1795, for example, the men who inventoried his possessions deemed but one coat, one wescot (waistcoat), and a single pair of stockings worth listing. ${ }^{336}$ Late in his life, William Haymond, Jr., the son of Major William Haymond, reminisced about what it had been like growing up on the western Virginia frontier. He wrote, "When I think of those times . . . it seems strange to me how the people survived many times with-out anything to eat and with but little to wear."337 The problem of inadequate clothing transcended practically every social class in the backcountry settlements.

Out of necessity, settlers in western Virginia manufactured the preponderance of their own clothing from raw materials either gathered from the forest or grown on their own farms. Settler John Scripps of Monongalia County explained how "Everybody made their own clothes of flax beginning with the cultivation of the staple." ${ }^{338}$ In addition to flax which settlers processed into linen, frontier families also relied heavily on wool and leather. Although some leather would have

\footnotetext{
${ }^{335}$ Doddridge, Notes on the Settlement, 92.

${ }^{336}$ Monongalia County Estate Book 1, 1.

${ }^{337}$ Haymond to Haymond, 18 March 1842, William Haymond, Jr., Papers, WVRHC.

${ }^{338}$ John Scripps quoted in Haymond, History of Harrison County, 272.
} 
been available from domestic animals, it more frequently came from wild game, particularly deer, elk, and to a lesser extent buffalo. Blacks bears with their thick hides and fur also saw use among frontiersmen. ${ }^{339}$ Most settlers would have known how to tan leather either through "vegetable tanning" with oak, sumac, or chestnut bark, or by "Indian tanning" which involved working the animal's tannic acid laden brains into the skin. ${ }^{340}$ Leather leggings, breeches, and hunting shirts although durable did not provide sufficient protection against the cold. Deer skin hunting shirts in particular proved to be "very cold and uncomfortable in wet weather." ${ }^{\text {"311 }}$ For these reasons, settlers and Indians alike preferred to manufacture their clothing from cloth.

The most common types of cloth seen on the western Virginia frontier included linen, wool, and a linsey-woolsey blend. Cotton and silk articles appeared much less frequently and would have been purchased commercially either at a frontier trading post or at a store back east. Settler William Scripps wore some higher quality clothing when he moved to western Virginia, however, after "grubbing in his broadcloth and satin ... they were [soon] worn out before he could get any other, for there were no stores in the country and no money in circulation to buy with if there had been. ${ }^{342}$ With few options and even less cash, settlers largely relied on home production to clothe themselves and their families.

${ }^{339}$ Belue, Long Hunt, 90.

${ }^{340}$ Bruce Schwaegel, "Brain Tanning Buckskin," in The Book of Buckskinning III, ed. William H. Scurlock (Texarkana, Tex.: Rebel Publishing, 1985), 82-83; Mark Odle, "Tools and Techniques of Bark Tanning," in The Book of Buckskinning VII, ed. William H. Scurlock (Texarkana, Tex.: Scurlck Publishing, 1995), 223-48.

${ }^{341}$ Doddridge, Notes on the Settlement, 91.

${ }^{342}$ John Scripps quoted in Haymond, History of Harrison County, 272. 
Linen is the cloth most frequently mentioned in the writings and memoirs of settlers from the western Virginia backcountry. The fabric is derived from the flax plant which is sown by broadcasting the seeds into a prepared field, or "flax patch," in mid-spring. The patch typically had to be weeded but once prior to harvest time in mid-July. Unlike oats or barley that are harvested by cutting the stalk, the flax plant must carefully be pulled from the ground roots and all. The reason for pulling flax is that the fiber found within the stalk extends downward into the root system. The timing of the flax harvest is critical because if pulled either too soon or too late, the fibers will not be suitable for spinning. ${ }^{343}$ If a pioneer family arrived on the frontier too late in the season to sow their crop, or if anything prevented them from harvesting their flax on time, they either did without, purchased commercial cloth, or looked to the surrounding forests for a suitable substitute. Resourceful families sometimes obtained useable fibers from the partially rotted stems of stinging nettles gathered in mid to late winter. ${ }^{344}$

Transforming a flax crop into usable cloth involved many labor-intensive steps. Luther Haymond, the grandson of Methodist lay minister Calder Haymond, explained the process.

As a general thing the people raised a patch of flax. This was pulled and spread on the ground to dry and then staked. After this it was spread out on a clear grassy sod to 'rot' as it was called. When sufficiently rotted from the stem to break easily, it was taken up and securely stacked for use as it might be wanted. The next operation was to brake it on a home made wooden brake. Then it was 'swingled' or skutched over the end of a board some 8 or 10 inches wide the other end being driven into the ground, and standing some three or four feet high. The fiber as it came from the brake was held in the left hand and about one half of it thrown over the board \& scutched with a long wooden blade till it was clean and soft. It was then hackled which separated the courser part from the finer part of

${ }^{343}$ Alastair J. Durie, The Scottish Linen Industry in the Eighteenth Century (Edinburgh, Scotland: John Donald Publishers) c. 1979), 2.

344،"The Life of Boone," Draper Manuscripts, 4 B 142-3, HSW; William Fleming, Draper Manuscripts, 2 ZZ 75 (8-9, 14-15), HSW. 
the [illegible]. ... The flax was then spun on a wheel by the mother and her daughters. The thread thus produced constituted the [illegible] of the finer quality of linsey which constituted the principal part of the material worn by the men and boys of the country.

Haymond described the linen shirts produced in this manner as being "pretty rough until used for some time." Otherwise, he found them to be "strong and durable.",345

In addition to linen, the settlers also manufactured clothing from the wool of sheep. Due to its insulating properties, wool had particular value in the production of cold weather clothing such as stockings, thick petticoats, capotes, mittens, caps, and as liners for homemade shoe packs. Unfortunately, it impossible to determine precisely how much wool would have been available to settlers in western Virginia. Local tax records did not enumerate sheep during the late eighteenth century and there are so few extant estate inventories that statistical data derived from them has little meaning. We know, for example, that when Indians killed settler Joseph Kinnan of Randolph County in 1791, he owned only three sheep. ${ }^{346}$ On the other hand, Monongalia County resident Bartholomew Jenkins died in mid-1796 owning twenty-one head of sheep. ${ }^{347}$ Whether either of these numbers reflects what might have been considered a typical size flock is difficult to say.

Although some settlers owned sufficient sheep to provide for all of their wool needs, not everyone was so fortunate. Indians and wild animals both killed sheep with regularity. In the early 1790s, the Scripps family had no wool "for wolves prevented our keeping sheep. We once

\footnotetext{
345"Reminiscences of Luther Haymond, 1896," William Haymond, Jr., Papers, WVRHC.

${ }^{346}$ Randolph County Will Book 1, 13.

${ }^{347}$ Monongalia County Estate Book 1, 45-46.
} 
got a flock of twenty but they were all destroyed.. ${ }^{348}$ Resourceful settlers sometimes substituted buffalo wool for sheep's wool. According to some reports, the best buffalo wool came from yearlings and two year old animals shot in February. Other settlers scavenged bits of buffalo wool off the ground in the spring of the year at buffalo wallows. There are even accounts of nettle and buffalo wool being woven together on a loom to produce a linsey-woolsey substitute. ${ }^{349}$ In short, when farm production failed to meet their material needs, the settlers could and did provide for their clothing needs by subsisting off of wildlife and forest resources.

The diet of the initial settlers, like their homes, tended to be very basic. ${ }^{350}$ Although predominately farmers, it took several years to develop a homestead to the point where it could provide a family with adequate food let alone a marketable surplus. ${ }^{351}$ Settler John Scripps recalled that during the first few years on the frontier, "few settlers had land in cultivation more than sufficient to raise food for their own consumption, and generally by Spring there would be no bread in the country and people lived on [wild] greens ... daily gathered by women and children." ${ }^{352}$ Joseph Doddridge also recalled having to "live without bread" for six weeks in 1773 when his family ran out of grain. They subsisted by eating venison, wild turkey, and bear meat, although "after living in this way for some time," the family "became sickly" and were "tormented

${ }^{348}$ John Scripps quoted in Haymond, History of Harrison County, 272.

349،"The Life of Boone," Draper MSS, 4 B 142-3.

${ }^{350}$ Leland D. Baldwin, Whiskey Rebels: The Story of a Frontier Uprising (Pittsburgh: University of Pittsburgh Press, 1939), 4.

${ }^{351}$ Mitchell, Commercialism and Frontier, 3, 134.

${ }^{352}$ John Scripps quoted in Haymond, History of Harrison County, 272. 
with a sense of hunger." ${ }^{353}$ Jacob Parkhurst similarly described how his family hunted wild game

to augment the limited quantities of corn, milk, and vegetables being produced on their family farm. ${ }^{354}$ Only by supplementing their meager farm products with wild game, nuts, and fruits did the initial settlers survive during their first few years on the frontier.

Although the forest provided the settlers with food, they also looked upon it as an impediment to agriculture. The massive trees supported a thick leafy canopy that cast the land into deep shade during the summer months. Growing crops in such a shadowy environment could simply not be done. In response, the settlers adopted the slash and burn farming methods that had long been employed by the Delawares and other tribes of Eastern Woodland Indians. ${ }^{355}$ A late eighteenth century observer described how the settlers cleared their land:

The general mode of clearing the land in this country, where timber is of no value, and labour is great, is by cutting a circle round the tree, through the bark, quite to the wood, before the sap rises, which kills it; and they ... [leave] the trees to rot standing, which happens within a very few years, and they never bear leaves more. ${ }^{356}$

The settler then disposed of the "deadenings" at his leisure. If a sufficient number of neighbors or family members lived close by, a "log-rolling" might be called in which communal work parties removed the underbrush and smaller dead wood, placed it in piles, and set it ablaze. They left

${ }^{353}$ Doddridge, Notes on the Settlement, 82.

${ }^{354}$ Jacob Parkhurst quoted in Core, Pioneers, 30.

${ }^{355}$ J. S. Otto and N. E. Anderson, "Slash-and-Burn Cultivation in the Highlands South: A Problem in Comparative Agricultural History," Comparative Studies in Society and History 24 (January 1982): 136-37.

${ }^{356}$ J. F. D. Smyth, A Tour of the United States of America, vol. 1 (1774; reprint, New York: Arno Press, 1968), 94. 
stumps, roots, and the larger tree trunks in place with little adverse effect on future crop yields. ${ }^{357}$

Once a plot had been cleared, settlers planted a wide variety of crops between the stumps and dead trees. Corn, potatoes, pumpkins, squash, beans, turnips, and other vegetables were staples of the pioneer diet. Sometimes, the settlers planted these crops in haphazard rows; other times, they planted Indian-style in thirty-inch diameter hills of mounded earth. ${ }^{358}$ Although they may not have realized it, planting in hills helped to reduce the danger of frosts by trapping the cold air close to the ground between the hills. ${ }^{359}$

After planting the same field for several successive years, erosion and soil exhaustion caused a marked decline in crop yields. A typical field could support a corn crop for anywhere from four to six years before losing its fertility. ${ }^{360}$ A heavy feeder such as tobacco, on the other hand, exhausted the soil after only three years. ${ }^{361}$ Regardless of the crop, when a field became exhausted, the settlers turned it over to fallow pasture and moved on to a newly cleared field. Over time, saplings and brush invaded the fallow field eventually restoring it to forest. After spending twenty years minimum as new growth forest, the soil recovered enough fertility to merit being cleared and planted in crops again. Forest fallowing required such a long period of time

${ }^{357}$ Otto, "Slash-and-Burn Cultivation,"133.

${ }^{358}$ Conrad E. Heidenreich, "Huron," in Northeast, vol. 15, Handbook of North American Indians (Washington, D.C.: Smithsonian Institution, 1978), 381.

${ }^{359}$ Bruce G. Trigger, The Huron: Farmers of the North, 2d ed. (Fort worth: Harcourt Brace Jovanovich College Publishers, 1990), 33.

${ }^{360}$ Trigger, Huron, 31.

${ }^{361}$ Allan Kulikoff, Tobacco and Slaves: The Development of Southern Cultures in the 
that seldom did a single person witness an entire cycle. ${ }^{362}$

Appalachian farmers found forest farming to be attractive for a number of reasons. For one thing, deadenings generated air currents that promoted the generation of dews and fogs that served as protection from unseasonable frosts. Another advantage of farming within deadenings is that the standing dead trees reduced the loss of moisture in plants by breaking up surface winds. Furthermore, burning brush not only killed weeds and insect pests on the ground, but it also helped to enrich the soil by providing it with potassium and other minerals found in wood ashes. Undoubtedly, the biggest benefit reaped by settlers practicing forest farming was that it saved them a tremendous amount of time and labor. After all, girdling trees and burning brush requires considerably less work than felling every last tree and grubbing out their massive stumps.

Considering that many backcountry families relied solely on their own labor, this last consideration is particularly important. ${ }^{363}$

Another laborsaving tactic of backcountry settlers involved the open-range grazing of cattle and hogs similar to what had been practiced by farmers in eastern Pennsylvania and the Shenandoah Valley. Open-range livestock needed far less care than animals kept in stables and fed grain or hay. One disadvantage, though, was that free range husbandry required extensive tracts of woodland where the animals could graze on wild grasses, leaves, and mast. Considering

Chesapeake, 1680-1800 (Chapel Hill: University of North Carolina Press, 1986), 47.

${ }^{362}$ John Fraser Hart, "Land Rotation in Appalachia," Geographical Review 67 (April 1977): 151; Kulikoff, Tobacco and Slaves, 47.

${ }^{363}$ Otto and Anderson, "Slash-and-Burn Cultivation," 141-42; Peter Nabokov and Dean Snow, "Farmers of the Woodlands," in America in 1492: The World of the Indian Peoples before the Arrival of Columbus, ed. Alvin M. Josephy, Jr. (New York: Alfred A. Knopf, 1993), 127. 
that few settlers possessed enough property to practice this system on their own land, they typically fenced in their grain fields and gardens leaving everyplace else, including the land of neighbors and absentee land owners, open for grazing. Hogs thrived in the woodlands while cattle did less well because of the sparseness of grass in the dim forests. Some farmers rectified this problem by setting fire to the forest floor in the late winter to promote the growth of springtime grasses. ${ }^{364}$ Open-range grazing helped to ensure that families had milk, butter, bacon, and perhaps even an occasional steer to consume as food or sell for cash.

As we have seen, the settlers who arrived in western Virginia during the final third of the eighteenth century relied very heavily on subsistence production to meet their daily needs and sustain their households. It would be a mistake, however, to envision them as being totally selfsufficient. Beyond being incredibly toilsome, subsistence production simply could not provide the settlers with every material comfort or convenience they desired. Muskets, black tea, Bibles, crosscut saws, indigo dye, and cast iron skillets all had to be carried across the mountains from the workshops or ports of Pennsylvania, Maryland, and eastern Virginia. To obtain these goods, the settlers needed cash, and to get cash they had to sell a commodity, whether it be farm produce, raw materials, or personal labor. Only by participating in the cash economy could the settlers achieve the level of competency they desired.

Even the widespread practice of trading work and borrowing tools from neighbors did not eliminate the need for participating in the commercial market. Not only had someone needed cash

${ }^{364}$ Otto and Anderson, "Slash-and-Burn Cultivation," 137; Ronald L. Lewis, Transforming the Appalachian Countryside: Railroads, Deforestation, and Social Change in West Virginia, 1880-1920 (Chapel Hill: University of North Carolina Press, 1998), 27; Smyth, Tour of the United States, 95-96. 
to purchase the borrowed item in the first place, but the settlers also generally kept track of the approximate monetary value of these informal exchanges so as to make it easier to know how much one owed his neighbors. Even the barter system as manifested in western Virginia depended on the commercial market to provide all of the necessary prices. ${ }^{365}$ For example, when customers at the Matthews Trading Post in the Greenbrier Valley bartered ginseng for consumer goods, the shopkeeper first converted the ginseng into its cash value that was then credited to the customer's account. The customer then used that credit to make purchases. ${ }^{366}$ Although no money changed hands, the entire transaction was based on both parties knowing the going monetary values not only for the ginseng, but also for the store goods. As historian Paul Salstrom pointed out, barter should not be viewed as an alternative to the commercial economy. Instead, it is better interpreted as the settlers' pragmatic solution to the problem of living in a specie short market economy. $^{367}$

Participation in a commercial economy is limited by several key factors. First, the prospective participant must possess a marketable commodity. For the settlers of western Virginia, these commodities included forest resources and agricultural products. Forest commodities, such as deer hides and ginseng, would have been available to the settlers in marketable quantities from the earliest days of settlement. Farm products, on the other hand,

${ }^{365}$ Salstrom, "Subsistence-Barter-and-Borrow Systems," 47, 51.

${ }^{366}$ Kenneth D. Swope, "Ginseng," Journal of the Greenbrier Historical Society 4, no. 2 (1982): 107; Otis K. Rice, A History of Greenbrier County (Lewisburg, W.Va.: Greenbrier Historical Society, 1986), 102.

${ }^{367}$ Paul Salstrom, “Appalachia's Informal Economy and the Transition to Capitalism," Journal of Appalachian Studies 2 (Fall 1996): 225. 
generally would only have been available in limited quantities until the Indian warfare abated and farms had been developed. According to settler John Scrips, "It was sometime before we had tillable land enough to raise wheat. Butter we could not indulge in, for what little we made with our surplus maple sugar at six cents a pound and a few eggs was all we could market to get money to pay taxes." 368

A second limiting factor is the small size of the market, or in other words, the number of individuals able to participate in the exchange of cash, credit, and commodities. ${ }^{369}$ The settlers who lived in western Virginia during the 1770s and 1780s had two potential markets: the local market, and the eastern markets centered on the cities of Richmond, Alexandria, and Philadelphia. Generally speaking, the local market in most of western Virginia offered few opportunities because of the low sparse population. In addition, by the mid-1770s, the Revolutionary War in combination with extensive Indian warfare had stifled immigration to the point that it practically eliminated the opportunity for already established settlers to sell food, seed, and livestock to newcomers. ${ }^{370}$ Furthermore, few settlers would have possessed commodities that their neighbors did not already have access to, such as corn or deer hides. Finally, western Virginians did not enjoy the economic benefits associated with being situated along a major transportation route, as did farmers in the Shenandoah Valley who regularly sold food to travelers on the Great Wagon

${ }^{368}$ John Scripps quoted in Haymond, History of Harrison County, 272.

${ }^{369}$ Barnes, “Avenues to a Market Economy,” 1.

${ }^{370}$ See chapter six for a discussion of the influence that Indian-related violence had on the population of western Virginia. 
Road. $^{371}$

A third factor that limited the settlers' ability to participate fully in the commercial economy was the absence of adequate transportation links with the eastern markets. As mentioned previously, not until after the Revolutionary War did western Virginians begin to upgrade their packhorse trails into fair weather wagon roads. Even then, the freight charges for bulky or heavy items tended to be so high that farmers could not afford to transport grain, flour, and other similar agricultural products across the mountains. ${ }^{372}$

Despite the challenges posed by a small population, a distant market, poor transportation links, and destruction at the hands of marauding Indians, the settlers nevertheless found ways to participate in the commercial economy in order to secure their competencies. Many settlers found the fur trade to be particularly attractive for a number of reasons. Unlike fruits and vegetables grown on a farm, furs could be transported long distances without spoiling. In addition, furs commanded a high price in relation to their bulk. And finally, hunters could harvest, process, and pack their furs to a distant market with minimal cash outlay. With just a gun, a few traps, and either a pack horse or canoe, and man could engage in commercial hunting. In early 1791 , William Haymond, Jr. and Jonathan Coburn embarked on a hunting/trapping expedition along the waters of the Little Kanawha River. Traveling in a homemade dugout canoe, they trapped several beavers and shot an otter, a buffalo, a four hundred pound black bear, and several deer. Upon reaching the town of Marietta, in present Ohio, they sold their skins and bear meat. ${ }^{373}$

\footnotetext{
${ }^{371}$ Mitchell, Commercialism and Frontier, 144.

${ }^{372}$ Baldwin, Whiskey Rebels, 25.

${ }^{373}$ Haymond to Haymond, 6 April 1842 and 18 April 1842, William Haymond, Jr., Papers, 132
} 
Reading the account of Haymond and Coburn's hunting trip raises the question of just how extensively did settlers engage in commercial hunting as they pursued a competent lifestyle? Although there is no way of determining the total number of skins exported from western Virginia during the late eighteenth century, insight into the scale of the region's fur trade can be gained, by examining the account books of the Mathews Trading Post. Over a twenty-month period from 9 August 1771 to 30 March 1773, proprietors Samson and George Mathews sent approximately 1,090 deerskins from their Greenbrier Valley store to their main store located in Staunton, Virginia. The majority of the skins came from customers who used them to pay on their accounts or to make purchases. Of the approximately four hundred customers named in the account books, only fifteen people exchanged deerskins on a regular basis. One man is listed as having sold approximately 230 skins at the store while two other customers exchanged over a hundred skins each. Most customers sold few or no skins at all. ${ }^{374}$ The entries in the account books suggest that while the fur trade was commercially important for some settlers, most people relegated it to a secondary position behind agriculture or a skilled trade.

Hunting "pest animals" provided another way for settlers in western Virginia to earn cash. In an effort to rid the region of "dangerous" animals, the General Assembly authorized county governments to pay bounties on the scalps of wolves. Under a 1764 law, the scalp of an adult wolf was valued at twelve shillings and six pence to the person submitting it to the county

WVRHC.

${ }^{374}$ Harry E. Handley, "The Mathews Trading Post," Journal of the Greenbrier Historical Society 1 (August 1963): 8-14; Rice, History of Greenbrier County, 102. 
court. ${ }^{375}$ In 1782 , the Assembly amended the law by doubling the wolf bounty. ${ }^{376}$ To an extent, a scalp was as good as cash. In fact, the legal right to a wolf scalp could even be transferred from one person to another. ${ }^{377}$ From 1787 through 1800, hunters in Randolph County collected bounties on 221 wolves. ${ }^{378}$ In the nineteenth century, the General Assembly expanded the bounty to include mountain lions, bears, bobcats, and foxes. ${ }^{379}$ Much like the fur trade, bounty hunting provided an opportunity for settlers to earn cash.

Ginseng was another forest commodity that contributed to the competency of some pioneer families in western Virginia. Although the settlers themselves generally did not use the plant in their home remedies, it did have value on the world market. Traders in western Virginia and the Shenandoah Valley bought the herb from settlers who actively searched the forests for "sang patches." The traders then sent their dried ginseng to Philadelphia where it was loaded onto ships destined for the cities of Glasgow and London from which it was re-shipped to the Chinese who used it medicinally and as an aphrodisiac. ${ }^{380}$ Starting in 1784 , some American

${ }^{375}$ William Waller Hening, ed., The Statutes at Large; Being a Collection of All the Laws of Virginia, 1619-1792 (Richmond: 1809-23), 8:48.

${ }^{376}$ Hening, Statutes, 11:64.

${ }^{377}$ Nathaniel Cochran Papers, PFMFA.

${ }^{378} \mathrm{Hu}$ Maxwell, The History of Randolph County, West Virginia (1898; reprint, Parsons, W. Va.: McClain, 1991), 216.

${ }^{379}$ William P. McNeel, "Pocahontas County," in History of Pocahontas County, West Virginia (Marlinton, W.Va.: Pocahontas County Historical Society, 1981), 21; Maxwell, History of Randolph County, 216.

${ }^{380}$ Durwood Dunn, Cades Cove: The Life and Death of a Southern Appalachian Community, 1818-1937 (Knoxville: University of Tennessee Press, 1988), 30-32; Mitchell, Commercialism and Frontier, 182. 
merchants began to ship ginseng directly to East Asia on their own vessels. ${ }^{381}$

Contemporary documents and settler's memoirs often mention gathering ginseng and other woodland herbs. The Reverend Henry Smith while preaching near Hackers Creek reported that "the men were all in the woods, some hunting, others digging ginseng and snakeroot" when Indians attacked the settlements. ${ }^{382}$ Settler James Wade dug ginseng as a youth in the Greenbrier region. "In Greenbrier, we got 50 cts. a lb. - could gather 2 lbs a day. It took $2 \mathrm{lbs}$ of green to make one of dry," but "it was scarce.",383 Settlers in the Greenbrier Valley regularly sold and traded their ginseng at the Mathews Trading Post. On 3 December 1772, for example, James Donaley traded forty-five pounds of ginseng for "knee buckles, fur hat, flannel, a comb and six yards of ozgns [osnaburg]." Nineteen days later, Robert Sconce arrived at the post laden with one hundred twenty-six pounds of ginseng for which he received nine pounds, nine shillings. In all, the account books name nine settlers who paid their accounts at the store with forty or more pounds of ginseng. ${ }^{384}$

In some instances, settlers gathered natural resources and cultivated produce on a scale that far exceeded what might be needed to achieve a competent household. Daniel Boone's involvement with the fur and ginseng trade exemplified this sort of small-scale backcountry capitalism. Following the Revolutionary War, Boone along with several hired hands dug ginseng

${ }^{381}$ Kim Derek Pritts, Ginseng: How to Find, Grow, and Use America's Forest Gold (Mechanicsburg, Pa.: Stackpole Books, 1995), 23.

${ }^{382}$ Henry Smith quoted in Core, Pioneers, 230.

${ }^{383}$ James Wade Interview, Draper Manuscripts, 12 CC 28, HSW.

${ }^{384}$ Kenneth D. Swope, “Ginseng,” 107; Rice, History of Greenbrier County, 102-3. 
and purchased it from anyone willing to sell. At one point in the spring of 1788, he had accumulated fifteen tons of ginseng although he lost some when one of his boats sank in the Ohio River. $^{385}$ By 1790, Boone had opened a trading post at the mouth of the Great Kanawha River where he accepted furs, meat, and ginseng in exchange for store goods. Settler James Lane spent the night at Boone's cabin that likely doubled as his store. According to Lane, "It was warm; Boone had some bear meat hanging in his cabin which dripped grease in my face as I lay there that night." 386 The scale of Boone's business is evidenced by a letter he received from Maryland merchant Matthew Vanlear confirming that he had received a shipment of furs and ginseng. The receipt lists 1,790 deerskins, 129 bear skins, 6 otter skins, 5 fox skins, and two barrels of ginseng. ${ }^{387}$ Within two years, however, Boone's trading business had gone the same way as his land speculation deals, and he found himself in debt with Vanlear requesting that Boone pay his account in full. $^{388}$

Overall, there is little evidence to suggest that very many settlers in western Virginia engaged directly in the Indian trade during the 1770s and 1780s. More typically, merchants such as John Gibson from Pennsylvania traveled to the Indians' villages in the Ohio country where they established trading posts. At these posts, Indian hunters exchanged their furs for a wide variety of English trade goods. As the merchants accumulated furs, they periodically shipped them up the

${ }^{385}$ Pritts, Ginseng, 24

${ }^{386}$ James Lane Interview, Draper Manuscripts, 12 CC 56, HSW.

${ }^{387}$ Vanlear to Boone, 27 April 1790, Draper Manuscripts, 27 C 5-6, HSW.

${ }^{388}$ Vanlear to Boone, 6 March 1792, Draper Manuscripts, 27 C 10, HSW; John Mack Faragher, Daniel Boone: The Life and Legend of an American Pioneer (New York: Henry Holt and Company, 1992), 265. 
Ohio River to Fort Pitt. While there, they procured additional goods to restock their posts and then returned to Ohio. With merchants physically present within the Indians' villages, there was simply no need for them to haul their furs to private residences in western Virginia. ${ }^{389}$

By no means did settlers limit themselves to the marketing of forest resources. After all, most settlers were farmers who practiced a diversified type of agriculture that included not only grain and vegetable production, but also the grazing of cattle and hogs. ${ }^{390}$ Much like their kinsmen in eastern Pennsylvania and the Shenandoah Valley, western farmers sought to produce crops that had value not only within their own homes, but also on the commercial market.

Potential markets for western Virginia farmers included the sugar islands of the West Indies where the best land was used for raising sugar cane rather than food; the growing urban centers of the eastern United States; and western Europe where a rising population had begun to outpace domestic food production. ${ }^{391}$ In the 1790s, yet another market opened in the lower Ohio Valley with the arrival of settlers in western Kentucky, southern Indiana, and southern Illinois. The Reverend Harry Toulmin reported from Kentucky in 1793 that although no apples are sold by local farmers, "apples from the Monongahela County [sell for] 6 shilling a bush[el]" and that "two

${ }^{389}$ John Gibson sworn deposition in Thomas Jefferson, Notes on the State of Virginia, ed. William Pedan (New York: Norton, 1954), 232-33; "Certificate of John Anderson," in Ibid, 23738 .

${ }^{390}$ Mitchell, Commercialism and Frontier, 133; Rasmussen, Absentee Landowning and Exploitation, 32.

${ }^{391}$ Richard K. MacMaster, "The Cattle Trade in Western Virginia, 1760-1830," in Appalachian Frontiers: Settlement, Society, and Development in the Preindustrial Era, ed. Robert D. Mitchell (Lexington: University Press of Kentucky, 1990), 133. 
thousand dollars are probably annually returned to that county for apples and cider." ${ }^{392}$

Although the Ohio River provided some settlers with access to markets in the lower Ohio Valley and later the port of New Orleans, the Allegheny Mountains still hindered interaction with the East. Wagon roads had been constructed across the mountains by the early 1790 s, however, their poor quality rendered them of limited value for carrying large scale commerce. ${ }^{393}$ Even the Monongahela River presented obstacles to commerce in the form of submerged rocks, tree trunks, "sweepers," and widely fluctuating water levels. Harrison County resident John G. Jackson recognized the importance of river channel improvement for transportation and commerce within western Virginia. Partially through his efforts, the Virginia legislature in 1793 passed a law creating a body of thirteen trustees to oversee the clearing of obstructions within the Monongahela and West Fork rivers. Additionally, the law forbade anyone from building a dam in the rivers without installing a slope to "admit the easy passage of fish" and a lock "for the convenient passage of canoes, batteaus, and flat bottomed boats." ${ }^{394}$ Although river improvements fostered commerce within the region, what farmers really needed were quality wagon roads across the Allegheny Mountains.

Poor transportation links particularly affected grain farmers in western Virginia. The sheer bulk of corn, rye, and wheat harvests prevented it from being hauled over the mountains in a cost effective manner. Freight wagons were of little use due to the ruggedness of mountain roads, and

${ }^{392}$ Harry Toulmin, The Western Backcountry in 1793: Reports on Kentucky and Virginia, ed. Marion Tinling and Godfrey Davies (San Marino, Calif.: Castle Press, 1948), 62.

${ }^{393}$ Core, Pioneers, 249.

${ }^{394}$ Samuel Shepherd, ed., The Statutes at Large of Virginia, From October Session 1792, to December Session 1806, Inclusive (Richmond: 1835), 1:242-43. 
it would have required an inordinate number of packhorses to use caravans. Transporting the harvest from even four acres of corn would have required about twenty-four animals. ${ }^{395}$ Some farmers solved the problem of transportation by distilling their grain into whiskey. In converting grain into alcohol, a twenty-four bushel harvest of rye could be converted into just sixteen gallons of whiskey; a load that even a single packhorse could handle. ${ }^{396}$ Distilling rye became so widespread in northwestern Virginia that by 1790, approximately one out of every eight households owned a copper still. Those families who could not afford to buy a still sometimes pooled their money with friends and relatives and bought one together. By the mid-1790s, Monongahela rye whiskey had established a niche among consumers not only in the East, but also in New Orleans, which received periodic flatboat shipments via the Ohio and Mississippi rivers. ${ }^{397}$

Another option for disposing of grain involved feeding it to hogs and cattle that could later be driven to eastern markets on the hoof. ${ }^{398}$ Settlers involved in this activity generally fell into two categories: 1) those who sold surplus livestock on an opportunistic basis, and 2) those who specialized in livestock grazing for the specific purpose of supplying eastern markets. To determine how many settlers could have engaged in each of these categories, it is necessary to know the number of people in each pioneer household, the number of cattle necessary for subsistence purposes, and the size of each person's cattle herd. By subtracting the number of

${ }^{395}$ Calculation based on information from Lemon, Best Poor Man's Country, 152 and Core, Pioneers, 177-78.

${ }^{396}$ Baldwin, Whiskey Rebels, 25; Lemon, Best Poor Man's Country, 152.

${ }^{397}$ Core, Pioneers, 177-79.

${ }^{398}$ Eugene J. Wilhelm, “Animal Drives: A Case Study in Historical Geography,” The Journal of Geography 66 (September 1967): 332. 
cattle needed for subsistence from the total number owned, it is possible to calculate the number of settlers who could have sold surplus animals without jeopardizing their competency.

Unfortunately, there is insufficient documentation to permit this sort of direct comparison between specific household sizes and cattle holdings. Still, it would be beneficial to examine the extant data and make some general observations.

Using Monongalia County in 1782 as a representative sample of households in western Virginia, it is possible to calculate the mean household size for the frontier population (table 1).

Table 1 .

Household Size in Monongalia County, 1782

$\begin{array}{lcc}\text { Number in } & \text { Number of } & \text { Percentage of } \\ \text { Household } & \text { Households } & \text { Households }\end{array}$

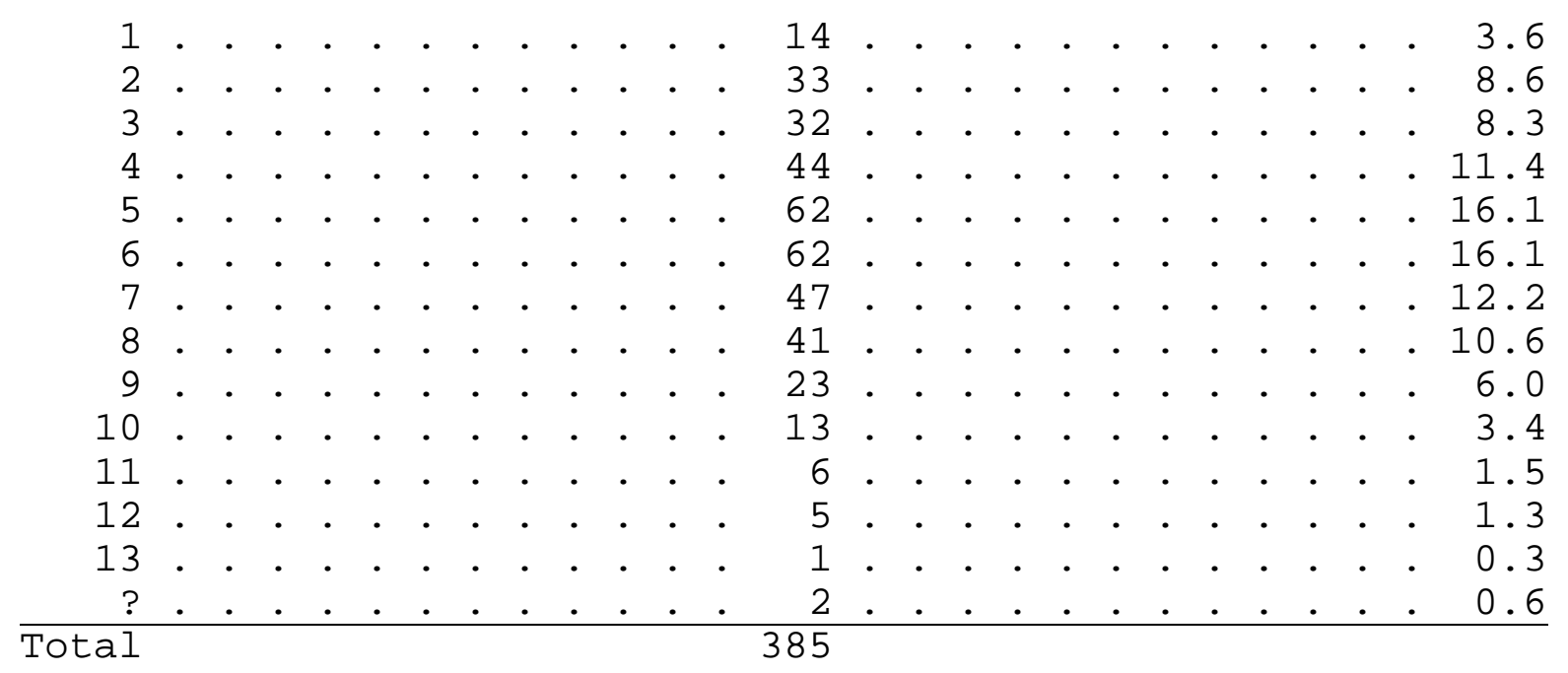

Source: Based on raw data in Core, Pioneers, 525-30. "This number includes only "white" people.

Based on the above data, Monongalia County in 1782 contained 2,169 white people in 385 different households. The mean household in western Virginia contained 5.6 individuals. This number is particularly significant considering that historical geographer James T. Lemon 
determined that a family of five required the products from five cows and half a steer to provide for their annual subsistence needs. ${ }^{399}$ If 5 people required 5.5 cattle, it can be extrapolated that 5.6 people required the products of about 6.1 cattle to sustain a competency.

Considering that a "typical" frontier family needed to keep a herd of about six animals, it would be valuable to know how many people actually maintained herds of this size. An analysis of cattle ownership based on the 1787 county property tax assessments for Harrison, Monongalia, and Randolph counties provides insight into this question (table 2).

Table 2 .

Cattle Herds in Select Western Virginia Counties, 1787

\begin{tabular}{lcrrrr} 
& $\begin{array}{l}\text { Number of } \\
\text { People Assessed } \\
\text { with Cattle }\end{array}$ & $1-6$ & $7-12$ & $13-19$ & $20+$ \\
County & 231 & 148 & 56 & 24 & 3 \\
Harrison & 266 & 189 & 61 & 15 & 1 \\
Monongalia & 144 & 65 & 55 & 17 & 7 \\
Randolph & 641 & 402 & 172 & 56 & 11 \\
\hline Totals: & 6 & & &
\end{tabular}

Source: County personal property tax lists for 1787. ${ }^{a}$ Monongalia County was divided into three tax districts. Only two of the district tax lists are extant.

Property owners with six or fewer cattle comprised 64 percent of those assessed with herds in Harrison County, 71 percent in Monongalia County, and 45 percent in Randolph County.

Considered together, a majority of about 60 percent of those settlers with cattle in the above three counties would not have had surplus stock to sell commercially if they also had to support a "typical" household of 5.6 people. Regardless of the precise household size for these small time herders, it is doubtful that any of them could have sold more than one steer per year on an

${ }^{399}$ Mitchell, Commercialism and Frontier, 141. 
opportunistic basis.

Nor can it be assumed that people assessed at between seven and nineteen head of cattle would have been in any better position to market more than one or two surplus steers per year. Thirty-six percent of frontier households were comprised of seven to thirteen people. For them to achieve their subsistence in cattle, approximately 36 percent of the herds in the region likewise must have ranged in size from seven to fourteen animals since about one animal per person was necessary for subsistence purposes. As it turns out, only considering herds that ranged in size from seven to nineteen animals can achieve the crucial 36 percent. In other words, even settlers with medium-sized herds of cattle probably could not have afforded to spare more than one or two steers per year.

Within each of the three counties, a small minority of settlers possessed herds in excess of twenty cattle. Although it would be tempting to declare that these settlers might have been involved in commercial cattle grazing, such a conclusion would be premature. One factor that has not yet been taken into consideration is the African slaves who lived in the three selected counties. Overall, African slaves comprised a small percentage of the population in the counties of Harrison, Monongalia, and Randolph. Extant documents reveal that eighty-one African Americans lived in Monongalia County in $1782 .{ }^{400}$ In other words, they comprised approximately 3.6 percent of the total population. With very few exceptions, most of them were slaves. It is crucial to our current discussion to know the distribution of slaves within the individual settlers' households because of the impact that large slave holdings would have had on the number of cattle necessary for a household to achieve a competency. Eighteenth-century Virginians

\footnotetext{
${ }^{400}$ Core, Pioneers, 177.
} 
considered slaves to be taxable property, therefore, they appear alongside cattle on county tax assessments. This permits not only an analysis of slave distribution, but also a direct comparison between slave holding and herd size (tables 3 and 4).

Table 3 . Slave Ownership in Select Western Virginia Counties, 1787

\begin{tabular}{|c|c|c|c|c|c|c|c|c|c|c|c|c|c|}
\hline \multirow[b]{2}{*}{ county } & \multirow{2}{*}{$\begin{array}{l}\text { Total } \\
\text { People } \\
\text { Assessed }\end{array}$} & \multicolumn{6}{|c|}{ Number of } & \multicolumn{3}{|c|}{ Slaves } & \multirow[b]{2}{*}{9} & \multirow[b]{2}{*}{10} & \multirow[b]{2}{*}{14} \\
\hline & & 0 & 1 & 2 & 3 & 4 & 5 & 6 & 7 & 8 & & & \\
\hline Harrison & 277 & 261 & 10 & 3 & 0 & 1 & 0 & 1 & 0 & 0 & 0 & 0 & 1 \\
\hline Monongalia & 318 & 289 & 11 & 3 & 4 & 6 & 1 & 1 & 2 & 1 & 0 & 0 & 0 \\
\hline Randolph & 185 & 178 & 2 & 0 & 2 & 0 & 0 & 2 & 1 & 0 & 0 & 0 & 0 \\
\hline
\end{tabular}

Source: County personal property tax lists for 1787. "Monongalia County was divided into three tax districts. Only two of the district tax lists are extant.

As demonstrated by table 3 only a minority of the assessed population within each of the three counties owned any slaves at all. Slave ownership was confined to 5.7 percent of those assessed in Harrison County, 9.1 percent in Monongalia County, and 3.8 percent in Randolph County. The implication of having so few slaveholders is that between 90 and 96 percent of the assessed population for each of the three counties would not have had to maintain extra cattle to help feed slaves. The lack of responsibility for maintaining slaves enabled settlers to sell more of their stock than would have been possible had they owned slaves.

But what about those few settlers that owned twenty or more head of cattle? As can be seen in table 4 there appears to have been a slight correlation between status as a slaveholder and the number of cattle owned. 
Table 4.

Settlers Assessed for Twenty or More Cattle, 1787

Name County Slaves Cattle

$\begin{array}{llll}\text { John Warwick } & \text { Randolph } & 7 & 69\end{array}$

$\begin{array}{llll}\text { Aron Richardson } & \text { Randolph } & 0 & 41\end{array}$

$\begin{array}{llll}\text { Thomas Wilmouth } & \text { Randolph } & 0 & 30\end{array}$

$\begin{array}{llll}\text { Benjamin Wilson } & \text { Harrison } & 30\end{array}$

$\begin{array}{llll}\text { William Dougherty } & \text { Monongalia } & 0 & 27\end{array}$

$\begin{array}{llll}\text { Edward Jackson } & \text { Randolph } & 0 & 26\end{array}$

$\begin{array}{llll}\text { John Crouch, Jr. } & \text { Randolph } & 0 & 23\end{array}$

John Powers $\quad$ Harrison $\quad 2 \quad 23$

William Robinson $\quad$ Harrison $\quad 0 \quad 22$

Jacob Stalnaker, Jr. $\quad$ Randolph $\quad 0 \quad 22$

Charles Fornelson, Sr. Randolph $\quad 0 \quad 21$

Source: County personal property tax lists for 1787 .

Where approximately 7 percent of the general frontier population held slaves, 27 percent of the largest cattle owners owned them. Although owning slaves would have required a settler to maintain extra cattle to provide for the slaves' subsistence, the wealthiest herders generally owned many more cattle than subsistence would have required. Also significant is the fact that eight of the largest cattle holders owned no slaves at all. Knowing this, it can be concluded that those settlers with more than twenty cattle did not maintain such sizable herds to feed their households or large gangs of slaves. More likely than not, they were producing large cattle surpluses for the commercial market.

Regardless of whether a settler raised livestock on a small or large scale, he derived no income from his efforts until his cattle had been successfully marketed. Sometimes, the market came to the settler in the form of professional drovers who had been hired by merchants to travel 
throughout the settlements soliciting marketable steers from each homestead. As the drover progressed through the backcountry, he gradually accumulated a herd that would be driven over the mountains to the Shenandoah Valley. The city of Winchester in the lower Valley served as an important center for the western Virginia cattle trade. ${ }^{401}$ In 1793, the Reverend Harry Toulmin noted in his journal the "multiplicity of cattle which pour through this town from the backcountry." ${ }^{, 402}$ In Winchester, drovers had the option of selling the cattle immediately or driving the herd onward to the markets of Baltimore, Philadelphia, Alexandria, or even New York. $^{403}$

Individual settlers sometimes took the initiative by driving their own cattle to the Shenandoah Valley markets. Generally, "mountain drives" involved only a handful of animals and two or three drovers. With so few workers, each cow normally wore a bell around its neck to help the drovers locate it in the event that it strayed. Few settlers ever had to go beyond the Shenandoah Valley in search of a buyer due to the large number of merchants and professional drovers that frequented the Winchester marketplace. After selling their cattle, the settlers typically purchased any needed supplies before returning home across the mountains. ${ }^{404}$ After being sold, the cattle were placed in temporary holding areas until enough had been assembled to

${ }^{401}$ MacMaster, "Cattle Trade in Western Virginia," 132-33, 135, 147.

${ }^{402}$ Toulmin, Western Country in 1793, 111-12.

${ }^{403}$ Paul R. Lilly, "The Drovers," Journal of the Greenbrier Historical Society 4, no. 6 (1986): 13; Salstrom, Appalachia 's Path to Dependency, 6; Mitchell, Commercialism and Frontier, 149.

${ }^{404}$ Wilhelm, "Animal Drives," 332-33; Mitchell, Commercialism and Frontier, 186; Doddridge, Notes on the Settlement, 97-98. 
merit a large-scale drive to the coast. Upon their arrival in cities such as Philadelphia, merchants had the cattle butchered, salted, barreled, and shipped either to the West Indies or to western Europe. In this way, the settlers of western Virginia helped to feed people throughout the Atlantic community while at the same time providing for their own competencies. ${ }^{405}$

By no means did the settlers limit themselves to the commercial production of cattle. They also raised surplus hogs for the marketplace. ${ }^{406}$ Unfortunately, the Virginia legislature did not require hogs to be enumerated in personal property assessments, therefore, much less is known about them. Extant wills and estate inventories provide some insight into the numbers of hogs maintained by the settlers, however the sample is so small that the enumerated results cannot be generalized with any degree of validity. In Monongalia County, for example, only nine inventories taken prior to the nineteenth century have survived, and according to them, settlers owned anywhere from zero to thirty-six hogs. ${ }^{407}$

In a few cases, anecdotal references to the marketing of hogs can be found in the county court and militia records. For example, in 1750, Jacob Coger was brought before the Augusta County Court for a "breach of the peace, by driving hogs over the Blue Ridge on the Sabbath day." ${ }^{408}$ In addition, some settlers sold pork and bacon to companies of county militia stationed at

${ }^{405}$ MacMaster, "Cattle Trade in Western Virginia," 133; Richard B. Sheridan, Sugar and Slavery: An Economic History of the British West Indies, 1623-1775 (Baltimore: Johns Hopkins University Press, 1973), 105-7, 315.

${ }^{406}$ Mitchell, Commercialism and Frontier, 186.

${ }^{407}$ Monongalia County Estate Book 1, 7, 45-46.

${ }^{408}$ John R. Commons et al, eds., Plantation and Frontier, vol. 2 of A Documentary History of American Industrial Society (New York: Russell and Russell, 1958), 287. 
nearby refuge forts. ${ }^{409}$ Although such evidence verifies that some settlers sold pork commercially, there is no way of determining the extent of the practice. The relative paucity of documentation on the marketing of hogs during the late eighteenth century compared with the abundance of documentation for the early nineteenth century suggests that commercial hog production was of overall minor importance to most of the earliest settlers in western Virginia. ${ }^{410}$

Although most settlers worked primarily as farmers, many of them supplemented their agricultural endeavors by producing manufactured goods or offering professional services. Once again, the account books from the Mathews trading post provide insight into this aspect of the backcountry economy. In an effort to clearly identify that an account belonged to, the accountant sometimes noted the occupation of a particular customer beside his name. In the Matthews' brothers books are listed three blacksmiths, one shoemaker, one saddler, two stone masons, one cooper, two weavers, one gunsmith, two carpenters, three tailors, one sawyer, two merchants, one miller, two packhorsemen, and seven jobbers. In all, at least twenty-nine of the approximately four hundred named customers did significant amounts of work in professions other than, or in addition to, agriculture. ${ }^{411}$

Even the Mathews trading post itself exemplifies the economically diversified nature of the backcountry economy. At its most basic level, the post served as a store where settlers purchased n.d), 11 .

${ }^{409}$ Henry Haymond, Historical References to Pricketts' Fort and Its Defenders. . . . (N.p.,

${ }^{410}$ On hog drives across southwestern Virginia during the early nineteenth century, see Mary Verhoeff, The Kentucky Mountains: Transportation and Commerce, 1750 to 1911, Filson Club Publication 26 (Louisville: John P. Morton, 1911), 99; and Charles Henry Ambler and Festus P. Summers, West Virginia: The Mountain State (New York: Prentice-Hall, 1940), 219.

${ }^{411}$ Rice, History of Greenbrier County, 103. 
both necessities and luxuries. Much of the inventory was tailored toward providing tools and supplies to mountain farmers. The Mathews brothers stocked nails, weeding hoes, grubbing hoes, chisels, axes, awls, handsaws, saddles, girths, gimlets, files, hasps, almanacs, cuttoe knives, bits and bridles, rasps, and drawing knives. The brothers also sold everything a frontiersman might need to shoot his flintlock rifle including powder, lead, flint, and replacement ramrods. For use in the home, the store carried dishes, needles, pen knives, trunks, padlocks, knives and forks, bed ticks, bags, alum, indigo, pins, cups, blankets, combs, mirrors, knitting needles, paper, pots, buckles, and thimbles. Luxury items available at the store included books, silk handkerchiefs, playing cards, flowered cloth, ribbons, and ready-made clothing such as leggings, garters, and shoes. The shear variety of consumer goods purchased by the Mathews' customers suggests that when possible, the settlers readily engaged in the commercial economy as a means of achieving a comfortable lifestyle somewhat above the level of mere subsistence. ${ }^{412}$

In addition to operating as a store, the post in many ways also functioned as a bank. It lent money to customers, charged interest on accounts, transferred money from one account to another, and even paid customer's land taxes to the sheriff. In addition to lending money, the account books also indicate that the post rented out tools. In 1773, for example, the Mathews brothers charged Edward Wilson's account for the use of a whipsaw. The store sometimes even lent farmers grain and corn seed for spring planting. Three customers went to the store to have watches repaired, and three customers paid for weaving. In fact, a number of customers even paid the post for having their horses shod. Patrons also bought meals at the post, ordered 60.

\footnotetext{
${ }^{412}$ Handley, "Mathews Trading Post," 8-14; Swope, "Mathews Trading Post Ledger," 20-
} 
bespoke clothing, and sold their rights to wolf scalps. On one occasion, a customer purchased a male servant of an unspecified race. In practice, the Mathews trading post gave real meaning to the term "general store" by providing the early Greenbrier settlers with a multitude of commercial services. ${ }^{413}$

The commercial economic structures revealed in the Mathews brothers' account ledgers are by no means particular to the Greenbrier Valley. Similar, albeit less well-documented, commercial patterns operated throughout the western Virginia frontier. ${ }^{414}$ Backcountry trading posts served as important links in the economic chain that connected the individual pioneer households to the greater Atlantic economy. By engaging in the commercial market as both producers and consumers of a wide range of commodities and services, the pioneers achieved levels of competency that would have been impossible to attain solely through the use of subsistence production. It is somewhat ironic that many classic symbols of pioneer selfsufficiency, such as flintlock rifles, double-bit axes, butter churns, and cast iron cookware, could generally be acquired only through the use of commercial economic structures.

${ }^{413}$ Handley, "Mathews Trading Post,” 8-14; Swope, "Mathews Trading Post Ledger,” 2060.

${ }^{414}$ Richard and Samuel McClure operated a store in the city of Wheeling shortly after the frontier period of West Virginia history came to a close. Although the extant account books for their store run from 1804 until 1810, the store functioned very much like the Mathews trading post of thirty years earlier. See Clifford M. Lewis, "A Frontier Store in West Virginia," West Virginia History 32 (July 1971): 238-44. 


\section{Chapter Six}

The Influence of Indian Warfare on Household Competency

During the years immediately prior to the outbreak of the American Revolution, hundreds of pioneer families crossed the Allegheny Mountains into western Virginia where they carved scattered homesteads from the heavily forested landscape. Despite the ruggedness of the terrain and the absence of any towns, these settlers built homes and provided for their household needs through a combination of forest farming, free range animal grazing, hunting, gathering forest products, and exchanging their surpluses for commercial goods at trading posts. Little did they realize that for the third time in as many decades, the entire region was about to erupt into a maelstrom of Indian raids, destruction, and death. As the violence raged off and on from 1774 through 1794, it frustrated the settlers' efforts to achieve economically competent households. The negative economic impact of the violence manifested itself in several ways. First, it caused widespread physical destruction to homesteads, livestock, property, and peoples' lives. Second, the region experienced population loss due to settlers abandoning the frontier during periods of particular danger. Third, the demand for active duty militiamen and Continental line troops diverted the labor of able-bodied men away from agriculture and artisanal work in favor of military service. And fourth, the settlers spent much of their time "forted up" for protection rather than improving their homesteads and communities. Each of these factors will be discussed in turn.

As we focus our attention on the issue of destruction to life and property, it must be 
emphasized that referring to the conflict between the Indians and Virginians as a "war" is somewhat of a misnomer. The word "war" typically implies "open and declared armed hostile conflict between states or nations. ${ }^{״ 415}$ The problem with categorizing the violence on the western Virginia frontier as "warfare" is that it occurred largely without the sanction of the Shawnees' tribal government. With the possible exception of Dunmore's War of 1774, at no point in the late eighteenth century did the Shawnees present a unified political, or military, front against the Virginians. This lack of unity can be attributed in part to the decentralized structure of their government. Although they had a principal chief who presided over the five Shawnee septs, the preponderance of political power rested within the various villages. Furthermore, unlike English political leaders, Shawnee chiefs lacked the authority to compel the obedience of their followers. Instead, each individual warrior decided whether to support or disregard a call to arms. Within such a system, leaders relied largely on personal charisma and the power of persuasion to fill the ranks of war parties.

As stated earlier, the tension between the Indians and Virginians revolved primarily around the ownership of the land and its resources. Like all Native Americans, the Shawnees enjoyed a special relationship with their homeland. They looked upon the soil, plants, and animals of the forest as gifts from Muyetelemilak, the Great Spirit, and Kokomthena, the Creator. ${ }^{416}$ According to Chief Cornstalk, "When God created this World he gave this Island [America] to the red

${ }^{415}$ Webster's Ninth New Collegiate Dictionary, s. v. "war."

${ }^{416}$ James H. Howard, Shawnee! The Ceremonialism of a Native American Tribe and its Cultural Background (Athens: Ohio University Press, 162-70. 
people . . . who live by Hunting and cannot subsist in any other way." ${ }^{, 417}$ Unfortunately, settlers and land speculators from Virginia valued the same resources as the Shawnees. Not only did settlers encroach upon Indian lands, but in many cases they even had little regard for fellow Virginians. Frontiersman William Crawford explained in 1772 that "As soon as a man's back is turned another is on his land. The man that is strong and able to make others afraid of him seems to have the best chance as times go now." ${ }^{418}$

Early on, some form of accommodation between the Virginians and Indians might have been possible, however, by the spring of 1774 , coexistence was no longer an option. Tensions had been on the rise for months. Even as early as February 1773, the missionary David Jones encountered deep hostility within the Shawnee villages in Ohio. One irate warrior even cried out in "venomous rage" that all he needed was "one stroke, one stroke" against the frightened minister who had hidden beneath a blanket in the loft of a cabin. ${ }^{419}$ Several months later in southwestern Virginia, a mixed party of Shawnees, Delawares, and Cherokees tortured and killed young Henry Russell and James Boone, a son of Daniel Boone. ${ }^{420}$ In another incident, some

${ }^{417}$ Cornstalk quoted in Colin G. Calloway, The American Revolution in Indian Country: Crisis and Diversity in Native American Communities (New York: Cambridge University Press, 1995), 166.

${ }^{418}$ Crawford to Washington, 15 March 1772, The Washington-Crawford Letters being the Correspondence Between George Washington and William Crawford from 1767 to 1781, ed. C. W. Butterfield (Cincinnati: Robert Clarke, 1877), 25.

${ }^{419}$ David Jones, A Journal of Two Visits Made to Some Nations of Indians on the West Side of the River Ohio, in the Years 1772 and 1773 (Chillicothe: Ohio, Ross County Historical Society, 1946), 11, 13.

${ }^{420}$ Mercer to Preston, 8 January 1774, Doc. Dunmore's War, 1-2; Campbell to Preston, undated, Doc. Dunmore's War, 39; John Mack Faragher, Daniel Boone: The Life and Legend of an American Pioneer (New York: Henry Holt and Company, 1992), 93. 
Shawnees captured seven men as they camped along the Ohio River, took them to their village, performed a war dance around them, and then released them. Shortly thereafter, a second party of more than twenty-five Shawnees recaptured the men, robbed them, and released them with a warning that all Virginians found on the Ohio River would be killed. ${ }^{421}$ In yet another incident in mid-April 1774, a skirmish between three men employed by Indian trader William Butler and a small party of Cherokees left one frontiersman dead and another wounded. ${ }^{422}$ Word of these attacks was "in every ones mouth" as fears grew that these isolated incidents might develop into a general uprising. ${ }^{423}$

By no means could the Virginians plead innocence as the violence intensified. Throughout the spring of 1774, American frontiersman committed a number of brutal attacks against Indians. In late April alone, a party under the leadership of settler Michael Cresap killed two Indian employees of William Butler, they murdered and scalped two additional peaceful Indians, and they attacked a Shawnee encampment located along Captina Creek near present Wheeling. ${ }^{424}$ Then on 30 April 1774, the escalating tension came to a head when a party of frontiersmen led by Daniel Greathouse ambushed and killed several people from the hunting camp of Logan, an influential

${ }^{421}$ Floyd to Preston, 26 April 1774, Doc. Dunmore's War, 7; John Jeremiah Jacob, A Biographical Sketch of the Life of the Late Captain Michael Cresap (Parsons, W. Va.: McClain, 1971), 54-55.

${ }^{422}$ Jacob, Life of the Late Captain Michael Cresap, 55.

${ }^{423}$ Campbell to Preston, undated, Doc. Dunmore's War, 39; Smith to Preston, 22 March 1774, Doc. Dunmore's War, 3.

${ }^{424}$ Randolph C. Downes, Council Fires on the Upper Ohio: A Narrative of Indian Affairs in the Upper Ohio Valley until 1795 (Pittsburgh: University of Pittsburgh Press, 1968), 161; George Rogers Clark, "Clark's Letter on the Speech of Logan," in Samuel W. Rogers, Jr., In My Father's House: The Life and Times of Chief John Logan (Logan, W. Va.: Radarta, 1990), 218. 
chief of the Ohio Iroquois, or "Mingo" Indians. ${ }^{425}$ Included among the casualties were Logan's mother, brother, and sister. ${ }^{426}$ In addition, the Virginians kidnapped Logan's infant niece. ${ }^{427}$ Throughout his life, Logan had been an avowed friend of the whites, however, upon learning of the massacre, he swore he would avenge their deaths. After sending the surviving members of his camp to the Shawnee village of Kispoko Town, Logan, along with eight warriors, unleashed his vengeance upon the frontier settlements of Virginia.

The mutual skirmishing and harassment that commenced in 1773 had escalated into fullfledged war by the summer of 1774 . Since it is not the intent of this paper to provide a detailed narrative of the military and political history of Dunmore's War nor the Indian raiding that occurred in conjunction with the American Revolution, let it suffice to say that the fighting that started in the spring of 1774 continued intermittently for the next twenty years. Not until 1794 when General Anthony Wayne dealt the Shawnees and other Ohio Indians a demoralizing defeat at the Battle of Fallen Timbers would the western Virginia "Indian wars," and frontier, come to a close. With few exceptions, most of the fighting that occurred in western Virginia would today be considered "guerrilla warfare." Engagements typically involved small numbers of people and frequently consisted of ambushes, skirmishing, and selective strikes against the enemy.

${ }^{425}$ John Sappington, "The Declaration of John Sappington," in Thomas Jefferson, Notes on the State of Virginia, ed. William Pedan (New York: Norton, 1954), 255-56.

${ }^{426}$ Gregory Schaaf, Wampum Belts and Peace Trees: George Morgan, Native Americans, and Revolutionary Diplomacy (Golden, Colo.: Fulcrum Publishing, 1990), 149.

${ }^{427}$ William Huston, "The Certificate of William Huston," in Jefferson, Notes on the State of Virginia, 237; Crawford to Washington, 8 May 1774, Washington-Crawford Letters, 48; Crawford to Washington, 7 May 1774, Washington-Crawford Letters, 87; Henry Jolly, "Reminiscences of Judge Henry Jolly," in Doc. Dunmore's War, 10-11. 
Collectively, these small-scale raids against European settlements proved highly destructive to life and property. Although the historic record is far from complete, insight into the amount and type of damage sustained by the settlers can be gained by analyzing the extant accounts of Indian attacks. Frontier narratives such as Alexander Scott Wither's Chronicles of Border Warfare detail dozens of attacks against the settlements. Additional accounts are lodged within the various county court records, the Draper manuscripts, military communications, county histories, and the unpublished memoirs of the settlers themselves. Considering that two centuries of court house fires and neglect have likely destroyed all evidence of some attacks while other attacks may never even have been recorded, the surviving record undoubtedly falls short of revealing the full extent of the carnage.

Although many of the above-mentioned sources are not primary documents, the modern researcher studying the western Virginia frontier in many cases has little choice but to consider them. During the 1770s and 1780s, no government agency on the frontier maintained detailed death records of those settlers who died as a result of Indian attacks. Despite some incidents going unrecorded at the time they occurred, the affected families and their neighbors told and retold the stories until they finally passed into the realm of oral history and folklore. An example of this sort of story is the account of a Mrs. Morgan and her young child who were taken captive from their Cheat River home. After a few days they escaped and wandered through the forest until discovered by some men from Prickett's Fort. ${ }^{428}$ While it is recognized that memory can be a very haphazard and selective thing, these oral accounts that eventually became lodged in the

${ }^{428}$ Alexander Scott Withers, Chronicles of Border Warfare (1895; reprint, Parsons, W. Va.: McClain, 1989), 240. 
multitude of nineteenth century local histories still have value to the modern historian studying the western Virginia Indian wars.

To achieve some insight into just how much damage may have been sustained by the settlers, a case study of the upper Monongahela Valley is presented. This geographical region includes the land drained by the upper Monongahela, Cheat, Tygart Valley, and West Fork rivers. In addition, limited portions of present southern Fayette and Greene counties in Pennsylvania have also been included because at the time, they fell within the political, geographic, and economic bounds of Monongalia County. All of the documented Indian attacks that occurred in this area during the four-year period from 1777 through 1780 have been analyzed. According to extant records, at least forty-seven different attacks occurred in the upper Monongalia Valley during the four-year period under consideration. In the course of these attacks, eighty-eight settlers are specifically mentioned as having been killed by the Indians. Unfortunately, in four of the attacks, the written account is too vague to determine the precise number of casualties. In 1777, for example, approximately twenty Indians attacked the homestead of Darby Connoly killing him, his wife, and "several of the children." 429 The following year, a war party struck a home where two or three families had gathered for mutual protection. In the course of that attack, the Indians killed one man and "the children in the yard."430 The other two ambiguous accounts refer to Indians killing "the women" and "some old men."431 By conservatively considering "women" and "some old men" to include at least four people, "several" to count as at

\footnotetext{
${ }^{429}$ Withers, Chronicles of Border Warfare, 234.

${ }^{430}$ Withers, Chronicles of Border Warfare, 279.

${ }^{431}$ Earl L. Core, The Pioneers, vol. 2 of The Monongalia Story: A Bicentennial History 
least three, and "the children in the yard" as five, the total casualty count for the four year period totals at least one hundred settlers. A hundred deaths acquires particular significance when one considers that by 1782 , Monongalia County had a population of less than twenty-three hundred people. ${ }^{432}$ In other words, the Indians killed approximately five percent of the county's population over a four-year period. Although certainly not the most destructive Indian war in American history, those settlers struggling to carve homesteads out of the Appalachian wilderness could hardly afford the losses. (See Appendix B for details on the various attacks.)

Additional casualties came in the form of settlers taken captive by the Indians. Over the course of the four-year period in question, Indians kidnapped dozens of men, women, and children from the upper Monongahela Valley settlements. While some captives ultimately found themselves adopted into Indian families as replacements for the deceased, such as four-year old Reuben Grigsby, others endured terrible torture and death at the stake. ${ }^{433}$ In some cases, the Shawnees even sold/traded captives to the British at Detroit or at Fort Niagara. In the spring of 1778, for example, a Shawnee war party captured settler Nathaniel Cochran as he worked in a field near Booths Creek in present Harrison County. When the British at Detroit showed no

(Parsons, W. Va.: McClain, 1976), 29; Withers, Chronicles of Border Warfare, 284.

${ }^{432}$ Core, Pioneers, 525-30.

${ }^{433}$ Reuben Gold Thwaites and Louise Phelps Kellogg, eds., Frontier Defense on the Upper Ohio, 1777-1778 (Madison: Wisconsin Historical Society, 1912), 37; Core, Pioneers, 7-8. Regarding the torture of captives, a classic example of the horrors of Indian torture is the ordeal of Colonel William Crawford, a Virginian who suffered a terrible death at the hands of Indians in 1782. For details of his torment, see Dr. John Knight, "The Narrative of Dr. Knight," in Indian Atrocities: Narratives of the Perils and Sufferings of Dr. Knight and John Slover, ed. H. Brackinridge (1843; reprint, Cincinnati: U. P. James, 1867), 20-25. The first edition of Dr. Knight's narrative was published in 1782 in Pittsburgh, Pennsylvania in pamphlet form. 
interest in purchasing him, his captors marched Cochrane along with several additional captives to Fort Niagara where British officials took him into custody and imprisoned him in Quebec where he languished until freed during a prisoner exchange in $1782 .{ }^{434}$

Between 1777 and 1780, the Indians captured at least forty-two settlers from northcentral western Virginia. Once again, the imprecise number is attributable to a vaguely worded account. ${ }^{435}$ Regardless, when the numbers of confirmed captives are added to the number of confirmed deaths, the total number of people effectively removed from the settlements totaled at least 142 individuals. Considering that backcountry settlements typically suffered from a shortage of labor, the loss of these settlers adversely affected the ability of the survivors to achieve a competency and to make improvements to their communities. An analysis of the various activities in which these victims were involved at the time of attack underscores the value of their labor. Of the 142 confirmed victims, the activities of eighty-five are specifically mentioned in the written accounts. These include: forting (36 victims), working in fields (27 victims), traveling (5 victims), working on cabins (5 victims), hunting (4 victims), and carrying out other miscellaneous subsistence activities such as grinding oats, repairing guns, making nails, gathering pine knots, making maple sugar, or carrying food to workers in the field (8 victims). Of these eighty-five victims, it is particularly significant that sixty of them became causalities while involved in a communal activity such as forting for mutual defense or participating in an agricultural work

${ }^{434}$ Nathaniel Cochrane Papers, "Nathaniel: A Traditional Account of the Capture and Imprisonment of Nathaniel Cochrane," PFMFA.

${ }^{435}$ In a 1778 attack on Harbert's Blockhouse in present Harrison County, "seven or eight children in the yard were killed or taken" captive by the Indians. Henry Haymond, History of Harrison County (Morgantown, W. Va.: Acme, 1910), 68. 
party. Not only does this high figure undermine the concept of pioneer self-reliance, but it also suggests that backwoods communities valued the labor of every member. Any casualty on the sparsely populated frontier reduced the ability of the community as a whole to defend, feed, and sustain it.

By no means did war parties limit themselves to attacks against persons. The Indians also targeted livestock, cabins, refuge forts, and other personal property. Unfortunately, the written record makes fewer references to property damage than it does human casualties. In part, this may be attributable to the fact that many contemporary accounts tended to be brief, particularly military correspondence. Writers either deemed property damage unimportant to the purpose of their message, or they may have assumed readers would automatically understand that property damage had likely occurred. Regardless, the available references to property damage do not easily lend themselves to meaningful quantification. Anecdotal accounts, on the other hand, indicate that some homesteads sustained considerable physical damage. A few representative examples convey the type of destruction that occurred. On 16 April 1778, for example, a war party "killed 7 sheep and skinned them and took 15 horses" in a raid near the mouth of the Cheat River. $^{436}$ On another occasion, a settler by the name of Johnson returned home from a hunting trip only to discover that his homestead had been attacked in his absence. In the front yard lay a dead cow and hog. In addition, the interior of his cabin had been ransacked. Over a mile away, the scalped bodies of his wife and three children lay on the forest floor. ${ }^{437}$ Other representative accounts mention the Indians stealing "a drove of cattle," stealing "at least 20 horses," plundering

${ }^{436}$ Thwaites, Frontier Defense, 23.

${ }^{437}$ William Haymond, Jr. to Luther Haymond, 25 March 1842, William Haymond, Jr. 
"the house of every thing," and that a war party burned a fort that was evacuated. ${ }^{438}$ Although there is no way of determining how much total damage occurred to the settlers' property, anecdotal accounts, such as those above, indicate that some families suffered considerably. ${ }^{439}$ In the face of such losses, attaining a competency became more difficult, not only for the survivors, but also for their friends and relatives who subsequently had to lend them support.

Aside from outright destruction to life and property, the Indian raids also hindered the economic development of the region by depopulating large portions of the frontier. Even the mere rumor of an Indian attack could prompt settlers to abandon their homesteads. In southwestern Virginia in the early spring of 1774, reports of a possible native uprising frightened some settlers so much that four families in one neighborhood set off "in Such haste that they left all their Stock and greatest part of their Household Furniture."440 When the fighting actually started later that spring, a "panic . . . seized the people" of the Monongahela and Ohio valleys. ${ }^{441}$ Over the course of just a few weeks, hundreds of frightened settlers abandoned their homesteads fleeing back "over the mountains" in such haste that many left behind personal belongings and

Papers, WVRHC.

${ }^{438}$ Thwaites, Frontier Defense, 23-24.

${ }^{439}$ Historian James Slaughter points out that even after the Revolutionary War ended, Indian attacks continued to ravage settlements in the upper Ohio Valley. Between 1783 and 1790, fifteen hundred frontiersmen are estimated to have been killed, wounded, or captured. Additionally, the Indians stole about two thousand horses during this same period. James P. Slaughter, The Whiskey Rebellion: Frontier Epilogue to the American Revolution (New York: Oxford University Press, 1986), 94.

${ }^{440}$ Smith to Preston, 22 March 1774, Thwaites, Doc. Dunmore's War, 3.

${ }^{441}$ Crawford to Washington, 8 June 1774, Butterfield, Washington-Crawford Letters, 51. 
livestock. ${ }^{42}$ One Fayette County, Pennsylvanian summed up the situation throughout the transAllegheny frontier when he wrote that "the country at this time is in great confusion. . . I suppose there have been broken up and gone off at least 500 families within one week past. ${ }^{, 43}$ That same year, 1774, the settlements around present Bridgeport "broke up and moved down to Prickets Settlement and Built a Fort" as protection against Indian attack. ${ }^{444}$ Five years later, the settlements along Hackers Creek in present Lewis County also broke up with some families "forsaking the country and retiring east of the mountains" while others moved into forts near present Buckhannon and Clarksburg. ${ }^{445}$

The depopulation that occurred in western Virginia during the late 1770s and early 1780 s adversely affected the economic development of the region in several ways. First, it reduced the number of workers (producers) available for clearing the forest, droving cattle, distilling whiskey, and cultivating the soil. Second, depopulation stifled the development of the local economy by reducing the number of consumers in the potential market. With the already low population experiencing further decline, merchants and artisans had little incentive to establish general stores and shops. Finally, the drop in population increased the tax burden on those settlers who remained behind. Counties in Virginia paid their expenses by laying a levy to cover the costs of surveying roads, constructing public buildings, purchasing supplies, paying bounties on wolves,

${ }^{442}$ Crawford to Washington, 25 May 1774, Butterfield, Washington-Crawford Letters, 89.

${ }^{443}$ Gilbert Simpson quoted in Allan W. Eckert, Sorrow in Our Heart: The Life of Tecumseh (New York: Bantam Books, 1992), 836.

${ }^{444}$ Jacob Rees, deceased, v. William, Benjamin, and Mackinney Robinson, O.S. 44: N.S. 15, Augusta County Court House (bill filed in Harrison County on 21 August 1797).

${ }^{445}$ Withers, Chronicles of Border Warfare, 275. 
and meeting the salaries of county officials. To raise the necessary funds, the county court simply divided the total levy by the number of male residents subject to the poll tax. This meant that as the population in Monongalia County declined, each man's share of the tax burden increased. Consequently, as their taxes increased, the ability of individual families to achieve a competency suffered. ${ }^{446}$

Beyond prompting some settlers to abandon the frontier outright, the threat of Indian attacks also negatively affected the number of new settlers arriving on the frontier. By examining the number of land grants issued to people who settled in Monongalia County for the years 1766 through 1782, the discouraging effect of the Indian war becomes evident (table 5).

${ }^{446}$ Netti Schreiner-Yantis and Florence Speakman Love, The Personal Property Tax Lists for the Years 1786, 1787 (partial) and 1788 for Monongalia County, Virginia (Springfield, Va.: Genealogical Books in Print, 1987), preface; William P. McNeel, "Pocahontas County," in History of Pocahontas County, West Virginia Va.: Pocahontas County Historical, 1981), 20. (Marlinton, W. 
Table 5 .

Documented New Settlers in Monongalia County

\begin{tabular}{|c|c|c|c|c|c|c|c|c|c|}
\hline Year & & & & & & & & & amber \\
\hline 1766 & • & • & - & • & . & • & . & & 7 \\
\hline 1767 & . & . & . & . & . & . & . & & 2 \\
\hline 1768 & . & . & . & . & . & . & . & & 4 \\
\hline 1769 & . & . & . & . & . & . & . & & 22 \\
\hline 1770 & . & . & . & . & . & . & . & & 91 \\
\hline 1771 & . & . & . & . & . & . & . & & 66 \\
\hline 1772 & . & . & . & . & . & . & . & & 143 \\
\hline 1773 & . & . & . & . & . & • & . & & 247 \\
\hline 1774 & . & . & . & . & . & . & . & & 168 \\
\hline 1775 & . & . & . & . & . & . & . & & 227 \\
\hline 1776 & . & • & . & . & . & • & . & & 139 \\
\hline 1777 & . & . & . & - & • & $\bullet^{\prime}$ & . & & 22 \\
\hline 1778 & . & . & . & . & . & - & . & & 7 \\
\hline 1779 & . & . & . & . & . & • & . & & 5 \\
\hline 1780 & . & . & . & . & . & • & . & & 2 \\
\hline 1781 & • & . & . & . & . & • & . & & 3 \\
\hline 1782 & . . & . & & . & - & • & . & & 1 \\
\hline Year & Unce & $r t$ & & & . & & . & & 59 \\
\hline
\end{tabular}

Source: Earl L.

Core, Prelude, vol. 1 of The Monongalia Story: A Bicentennial History (Parsons, W. Va.: McClain, 1976), 158-59. The year represents when the grantee settled in Monongalia County, not when he formally received his land grant.

The low number of settlements for the period 1766 to 1768 is attributable to a combination of Pontiac's Uprising which concluded in 1765 and the royal Proclamation of 1763 forbidding settlement west of the Allegheny Mountains. ${ }^{447}$ In the fall of 1768, the first Fort Stanwix Treaty adjusted the proclamation line westward to coincide with the Ohio River thus legalizing the settlement of large portions of western Virginia. Consequently, the following year, 1769 , sees the beginning of a generally steady increase in the number of settlers arriving in

${ }^{447}$ William Waller Hening, ed., The Statutes at Large; Being a Collection of All the Laws of Virginia, 1619-1792 (Richmond: 1809-23), 7:667. 
Monongalia County. ${ }^{448}$ The relatively peaceful disposition of the Shawnees during the years 1769 through 1773 further facilitated an increase in the number of settlements. By 1774, however, the number of new arrivals had reached the critical juncture where their physical presence began to seriously impede the Shawnees' ability to subsist off the land. The indirect result was Dunmore's War of 1774. The 32 percent drop that year in the number of new settlers reflected the dangerous conditions on the frontier. Throughout 1775, the Shawnees, still stinging from their defeat at the Battle of Point Pleasant, remained at peace. Not surprisingly, the annual number of new settlers arriving in western Virginia almost returned to its pre-war level. By late 1776, however, the Ohio Iroquois along with many of the Chalagawtha, Kispokotha, and Peckuwe Shawnees had loosely joined with the British in a war against the Americans. ${ }^{449}$ As war parties again struck the backcountry settlements, the number of new families arriving in western Virginia saw a marked decline. From 1776 through the end of the Revolution, the danger of Indian attacks discouraged settlement west of the mountains. ${ }^{450}$

The population loss in the settlements resulting from killings, captivity, and evacuation was further accentuated when the Virginia Assembly in 1775 began to call up men for service in two regiments being raised for the defense of the colony. Twenty-five of these men would be stationed at Fort Henry (Wheeling) while a hundred more would serve at Fort Blair (Point Pleasant). Over the next seven years, the Assembly passed additional legislation on an annual

${ }^{448}$ Otis K. Rice, The Allegheny Frontier: West Virginia Beginnings, 1730-1830 (Lexington: University Press of Kentucky, 1970), 64.

${ }^{449}$ Calloway, American Revolution in Indian Country, 165; Downes, Council Fires on the Upper Ohio, 190-91.

${ }^{450}$ Slaughter, Whiskey Rebellion, 66. 
basis requiring every county in Virginia to provide troops for service within the Virginia State Line and/or the Continental Army. In 1782, for example, Virginia ordered Ohio, Greenbrier, and Monongalia counties to send every fifteenth militiaman to the Continental Army. If insufficient volunteers stepped forward, the difference would be drafted into service. Considering that enlistments could last for anywhere from nine months to three years, western Virginia experienced a significant, albeit temporary, decline in population due to requisitions for soldiers. In 1776 alone, trans-Allegheny Virginia had to provide 735 able-bodied men to the Continental Army. To be considered able-bodied, a man had to "be not less than five feet and four inches, not a deserter nor subject to fits, but of able body and sound mind, and fit for immediate service." The Assembly later specified that soldiers had to be between the ages of eighteen and fifty. ${ }^{451}$ In effect, those settlers most capable of clearing the land, planting crops, blazing roads, building homes, and developing industry were the same ones subject to requisition by the military. By removing these men from the backcountry settlements to serve in the army, the Revolutionary War played a part in prolonging the raw frontier phase of "West Virginia" history.

Those settlers who remained in the backcountry defended themselves through a combination of county militias and constructing refuge forts to be used as places of respite during times of danger. Naturally, it was to the settlers' advantage if they could discover ahead of time when a war party was about to enter their vicinity. To provide this advanced warning, militia scouts, also known as "Indian spies," constantly patrolled the forest looking for signs of enemy activity. Upon discovering footprints or other evidence, the scouts tried to ascertain the size of

${ }^{451}$ Hening, Statutes, 9:13, 9:179-82, 9:339-40, 9:588-89, 10:18-20, 10:32-33, 10:257-58, 10:327-29, 10:433-34, 11:14. 
the party, their tribal affiliation, their most probable route, and whether they had hostile intentions. If the situation warranted it, the scouts sent news of the incursion to the nearest militia commander. $^{452}$ On 17 July 1777, for example, two scouts operating along Buffalo Creek near present Fairmont reported to their commander that they had discovered the footprints of seven or eight Indians heading in the direction of the settlements. ${ }^{453}$

In hopes of averting disaster, scouts "would fly from Fort to Fort and give the alarm" warning nearby settlers of impending danger. ${ }^{454}$ One man who grew up on the western frontier recalled how his family was "sometimes waked up in the dead of night" by runners telling everyone to fort up. His father would immediately grab his gun and powder horn while the rest of the family got dressed. Everyone tried to be as quiet as possible and took the "greatest care ... not to awaken the youngest child." Without lighting a candle, the family grabbed what "articles of clothing and provision" they could. Oftentimes, they had no choice but to walk to the fort "for there was no possibility of getting a horse in the night." By sunrise, all of his neighbors had also arrived at the fort. Then over the course of the day, armed parties of men visited each homestead to pick up additional food, clothing, valuables, and other supplies that might be needed at the fort. $^{455}$

How long a family remained at a refuge fort could vary. While some families stayed for

${ }^{452}$ Thwaites, Doc. Dunmore's War, 4-5.

${ }^{453}$ Thwaites, Frontier Defense, 23.

${ }^{454}$ National Archives, Revolutionary War Pension and Bounty Land Warrant Application Files, 1800-1900. Record Group 15. "Michael Swope."

${ }^{455}$ Joseph Doddridge, Notes on the Settlement and Indian Wars (1912: reprint, Parsons: W. Va.: McClain, 1976), 95. 
only short periods before returning home, others remained there for months. ${ }^{456}$ Noise, crowded living conditions, disease, and concerns over unguarded homesteads could make forting an unpleasant experience. Fortunately for the settlers, forting tended to be a seasonal activity with the greatest need for forts being in the spring, summer, and early fall. Deep snows, cold winter weather, and leafless trees hindered forest warfare and generally kept Shawnee warriors at home. Understandably, most settlers breathed a sigh of relief with the arrival of cold weather because it presaged a few months respite before the spring thaw brought a renewal of hostilities. Sometimes in late fall, however, a few weeks of "Indian summer" permitted the war parties to strike the settlements one final time before winter set in to stay. ${ }^{457}$

Although refuge forts mitigated the destruction caused by Indian attacks, their construction and use diverted a tremendous amount of labor away from agriculture, artisanal work, and the development of industry. Consider for a moment the effort required to construct even a modest stockade fort measuring about fifty feet square. According to one Virginia militia officer, it required a hundred men one week to build such a structure. ${ }^{458}$ Assuming a forty-hour workweek, the construction of such a fort required a labor investment of four thousand manhours. This in itself does not seem like an inordinate amount of labor until one considers that the settlers built literally dozens of defensive structures throughout the Virginia backcountry. In the upper Monongahela Valley alone, forty-five refuge forts and blockhouses provided shelter to

${ }^{456}$ W. Stephen McBride, Kim Arbogast McBride, and Greg Adamson, Frontier Forts in West Virginia: Historical and Archaeological Explorations (Charleston: West Virginia Division of Culture and History, 2003), 28.

${ }^{457}$ Doddridge, Notes on the Settlement, 204-205.

${ }^{458}$ Thwaites, Doc. Dunmore's War, 46-47. 
pioneer families. ${ }^{459}$ Although many of these structures consisted solely of a two-storey blockhouse, others comprised a complex of sleeping cabins, corner blockhouses, and twelve-foot tall stockade walls sunk deep into the ground. ${ }^{460}$ Knowing that some forts required less and others more labor to construct than a small stockade fort, it can be estimated that the settlers in the upper Monongahela Valley alone had upwards of a hundred thousand man-hours invested in constructing fortifications. (See Maps 3, 4, and 5)

Even the act of forting itself diminished the settlers' ability to achieve a competency by removing them from their homesteads for extended periods of time. While away, fields went uncleared, gardens went unprotected, and nobody improved their homesteads by building fences, outbuildings, or other structures that would have enhanced one's standard of living. The fact that the Shawnees preferred to raid during the busiest times of the agricultural calendar only accentuated this deleterious aspect of forting. Because of the seasonal nature of raiding, an entire generation of western Virginians grew up "forting in the summer and staying at home in the winter. ${ }^{, 461}$ One settler observed that during times of danger, the entire countryside appeared deserted because everyone had moved to the forts. He lamented that while away from the homestead, unprotected livestock fell prey to wolves, bears, and mountain lions and that freerange cattle and hogs broke through fences into gardens and cornfields. Thus, after working so

${ }^{459}$ Donovan H. Bond, "Frontier Forts of Monongalia County," in Earl L. Core, The Prelude, vol. 1 of The Monongalia Story: A Bicentennial History (Parsons, W. Va.: McClain, 1976), 333-65; Roy Bird Cook, "Virginia Frontier Defenses, 1719-1795," West Virginia History 1 (January 1940): 119-30.

\footnotetext{
${ }^{460}$ J. Miles Prickett Papers, PFMFA; Doddridge, Notes on the Settlement, 94.

${ }^{461}$ Jacob Parkhurst quoted in Core, Pioneers, 31.
} 
hard to clear their land and plant crops, the settlers had little choice but to sacrifice their economic security (competency) in favor of physical security. ${ }^{462}$

In an attempt to overcome this problem, armed work parties occasionally left the safety of the forts to perform chores at the various member's homesteads. While some settlers worked the farm, others stood guard at strategic locations watching for any signs of Indians. Despite these precautions, the Shawnees proved exceptionally effective at ambushing work parties. ${ }^{463}$ Because so many farms received only intermittent care throughout the growing season, agricultural productivity for the region tended to be lower than if times had been peaceful. ${ }^{464}$

Beyond diverting the settlers' labor into the construction of fortifications, the fighting also necessitated the frequent activation of the county militia. With American Continental Line troops occupied with the British, the defense of the settlements fell primarily upon the settlers themselves. In 1777, Virginia passed a militia law requiring with few exceptions that every ablebodied free male aged sixteen to fifty enroll in their county militia. Beyond mustering once a month during peacetime, each soldier had to provide his own equipment including a gun, shot pouch, tomahawk or bayonet, and enough powder and lead ball for three shots. ${ }^{465}$ During times of danger, activated militia units served as a full time county defense force. The shortage of

${ }^{462}$ Doddridge, Notes on the Settlement, 109.

${ }^{463}$ For a firsthand account of a work party being attacked by Indians near present Bridgeport, West Virginia, see "The Declaration of William Robinson" in Jefferson, Notes on the State of Virginia, 242; Doddridge, Notes on the Settlement, 109.

${ }^{464}$ Doddridge, Notes on the Settlement, 109-110.

${ }^{465}$ Hening, Statutes, 13:27-28. The old militia law had lapsed in 1774 when Governor Dunmore dissolving the Assembly before it could renew the old legislation. 
available troops sometimes prompted militia captains to enlist men older than fifty. In 1774, for example, Captain Zackwell Morgan's company stationed at Prickett's Fort included Thomas Hellen, "an old man."466 Although Virginia authorities did not hesitate to punish blatant transgressors of the militia law, they also demonstrated a surprising degree of latitude when extenuating circumstances, such as sickness or poverty, prevented a man from complying with the militia law. $^{467}$

Militia troops had a wide range of responsibilities associated with frontier defense. They built and garrisoned forts, scouted for signs of Indian activity, carried dispatches between forts, pursued Indian war parties, recovered captives, and sometimes even took part in distant military campaigns. ${ }^{468}$ The experiences of settler Jacob Bush illustrate the amount of time and effort that could be asked of the county militia. In the spring of 1781, his militia company marched from Buckhannon Fort, to Nutter Fort, to present Morgantown, and then on toward Pittsburgh. There they boarded boats and descended the Ohio River to the present site of Louisville where the command decided to abandon their planned assault on the Indian towns of central Ohio. The army eventually disbanded in Kentucky leaving every man responsible for finding his own way home to western Virginia. Unfortunately, Bush and "many others became sick with the fever"

${ }^{466}$ Fort Pitt Pay Book, 4 October 1775, Virginia State Archives, Richmond, Virginia; Withers, Chronicles of Border Warfare, 156-57.

${ }^{467}$ Lloyd DeWitt Bockstruck, Virginia's Colonial Soldiers (Baltimore: Genealogical Publishing, 1988), 319-54.

${ }^{468}$ National Archives, Revolutionary War Pension and Bounty Land Warrant Application Files, 1800-1900. Record Group 15. "Francis Goodwin;" Militia at Prickett's Fort File, PFMFA; Thwaites, Frontier Defense, 37; Core, Pioneers, 7-8; Withers, Chronicles of Border Warfare, 217-18. 
and could not travel until the following year when they finally made it back home. ${ }^{469}$ Although the militia performed critical services on the frontier, the demands that it placed on its members reduced their standard of living by forcing them to labor at activities that did not directly contribute to the competency of their households. If the state could only have afforded to provide these men with a regular dependable pay, their militia service might not have been such an economic liability. ${ }^{470}$

Throughout the final quarter of the eighteenth century, fighting between the settlers and Indians deprived both peoples of the full economic benefits of possessing the land and its resources. The result was a marked decline in the standard of living within both societies. ${ }^{471}$ By 1779 , the Shawnees had grown so weary of the death and suffering caused by the fighting that many decided to abandon their homeland rather than continue to resist white encroachment. Under the leadership of chiefs Yellow Hawk and Black Stump, about twelve hundred Shawnees left the upper Ohio Valley and moved down the Ohio River ultimately reaching present Missouri where they took up residence under the auspices of Spanish authorities. ${ }^{472}$ Many of those who remained in the Ohio country continued to fight until General Anthony Wayne defeated them, along with most of the other tribes of the Old Northwest, at the Battle of Fallen Timbers near present Toledo, Ohio in 1794. The following year, the majority of the Shawnees' surviving chiefs

${ }^{469}$ Jacob Bush, "Revolutionary War Pension Application," in Lucullus Virgil McWhorter, The Border Settlers of Northwestern Virginia, from 1768 to 1795 (1915; reprint, Parsons, W. Va.: McClain, 2000), 111-12.

${ }^{470}$ Doddridge, Notes on the Settlement, 15.

${ }^{471}$ Slaughter, Whiskey Rebels, 70.

${ }^{472}$ Calloway, American Revolution in Indian Country, 169-70. 
relinquished their tribal claims to the upper Ohio Valley at the Treaty of Greenville. Removed from their land and resources, the remaining Shawnees languished as they tried to survive on meager annuity payments from the federal government. ${ }^{473}$

Like the Shawnees, many settlers also experienced great hardship as a result of the fighting. Living on a remote frontier away from the conveniences of an established commercial market was difficult enough in peacetime, let alone during a protracted Indian war. ${ }^{474}$ If not for the armed resistance of the Shawnees and other Ohio Valley Indians, the economic development of western Virginia would have progressed more rapidly than it did otherwise. Writing to his brother in 1796 as the western Virginia frontier came to a close, Dr. Erich Bollman explained, "Only lately have the Indians ceased roving in this vicinity; which has done much to delay its cultivation." 475 The fact that the settlement of trans-Allegheny Virginia coincided not only with a prolonged "Indian war," but also with the Revolutionary War sets it apart from Appalachian regions settled during peacetime.

${ }^{473}$ Janet Hubbard-Brown, The Shawnee (New York: Chelsea House, 1995), 76-77, 80-82.

${ }^{474}$ Doddridge, Notes on the Settlement, 87.

${ }^{475}$ Erich Bollman quoted in Archer Butler Hulbert, Pioneer Roads and Experiences of Travelers, Volume II, vol. 12 of Historic Highways of America (Cincinnati: Arthur H. Clark Company, 1904), 80. 


\section{Chapter Seven}

Summary and Conclusion

In an Appalachian studies textbook from 1983, the editors declared it to be the "collective task" of Appalachian scholars "to present ideas and information to demythologize the half-truths" that have dominated their topic for so long. ${ }^{476}$ This present study on the relationship between Indian-related violence, backcountry warfare, and the duration of the frontier period of West Virginia history is an effort to do just that. It is part of an ongoing dialogue that actually began in the late nineteenth century when local color authors such as Will Wallace Harney, James Lane Allen, and John Fox, Jr., planted the idea in the American conscience that when you journey to the Appalachian Mountains "you detach yourself from all that you have experienced, and take up the history of English speaking men and women at the point it had reached . . . a hundred and fifty years ago."477 In other words, they sowed the seed that ultimately grew into the pervasive perception that modern Appalachia is a "contemporary survival of . . pioneer life." It is a place where the descendants of the settlers allegedly became trapped in the "log-cabin stage" of existence. $^{478}$

${ }^{476}$ Bruce Ergood and Bruce E. Kuhre, eds., Appalachia: Social Context Past and Present (Dubuque, Iowa: Kendall/Hunt, 1983), v.

${ }^{477}$ Will Wallace Harney, “A Strange Land and a Peculiar People," Lippincott's Magazine 12 (October 1873): 429-38; John Fox, Jr., The Trail of the Lonesome Pine (New York: Charles Scribner's Sons, 1908), 87. Quote from James Lane Allen, “Through Cumberland Gap on Horseback," Harper's Magazine, 73 (June 1886): 50-66.

${ }^{478}$ William Goodell Frost, "Our Contemporary Ancestors in the Southern Mountains," Atlantic Monthly 83 (March 1899): 311-19. 
Today we largely realize that this romantic image of Appalachia being a persistent frontier is but an illusion. In an attempt to correct this misconception, some modern scholars have presented an alternate model that unfortunately "swings the pendulum" too far in the opposite direction by arguing that the austere period of the Appalachian frontier lasted but a year or two. The problem with such an interpretation is that it largely fails to account for the deleterious effects that Indian raids and warfare had on some portions of the Appalachian Mountains. In areas susceptible to Indian attacks, the resultant destruction, depopulation, and death profoundly affected the duration of difficult frontier living conditions for those particular sub-regions. The western Virginia frontier from the mid-1750s through the mid-1790s is presented in this dissertation as a case in point.

Part of the problem with developing a model to help explain the frontier, is the ambiguity of the word itself. As explained in chapter two, frontiers not only encompass physical space, but they also contain a dynamic human element involving two or more distinct societies who typically compete for political, cultural, and economic hegemony. The frontier period of a region commences with first contact between these societies and it concludes when one of them achieves dominance. In the case of western Virginia, the frontier period began in the 1670s with the appearance of European explorers, hunters, and trade goods and it lasted until 1794 when the United States defeated the Indians of the upper Ohio Valley at the Battle of Fallen Timbers near present Toledo, Ohio in 1794. Over the course of this period, Native Americans in the upper Ohio Valley gradually succumbed to a combination of diseases, intertribal warfare, displacement, involvement in colonial wars, and the erosion of their native cultures through the introduction of 
European technology and belief-systems. Thus, by the time actual Euro-American settlers began to arrive in western Virginia during the early 1750s, the frontier period of "West Virginia" history had already been in existence for over seventy years.

In chapter three, the Shawnees are introduced as the dominant Indian group encountered by settlers in the upper Ohio Valley. Not surprisingly, they offered the most stalwart resistance to European intrusion during the second half of the eighteenth century. Perhaps the Shawnees' determination rested in the fact that they recognized the Ohio Valley as their ancestral homeland. Regardless, settlers soon began to characterize the Shawnees as being an inherently "warlike" people. The purposes of this chapter are threefold. First, by examining the Shawnees' culture and lifestyle, they are recognized as a people who possessed significance and an identity independent of their European rivals. In other words, the Shawnees must not be cast solely in an oppositional role to the "hardy pioneer heroes." Second, it is demonstrated that although Shawnee society did contain elements of violence involving torture, cannibalism, kidnapping, and raids against enemies, these practices occurred within the context of a sophisticated belief system and did not stem from "animalistic savagery." And third, by examining in depth how the Shawnees derived their subsistence from the land and its resources, it becomes evident that Indians and settlers both needed access to the land in order to avoid destitution. In the course of their long struggle, both sides deprived one another of the full benefit of possessing the land and its resources, thus contributing to a prolonged and difficult frontier experience for everyone involved.

One of the critical questions addressed in chapter four is whether the cultural background 
of the settlers played any part in determining the type of interaction with the Indians. After all, if the Indians peacefully coexisted with some categories of Europeans, but consistently fought against others, then the dynamic, or driving force, in the frontier history of western Virginia might better be explained by cultural factors rather than violence. In answering this question, it is first demonstrated that cultural diversity indeed existed among the settlers themselves. Then, by using representatives of these various settler "types" as case studies, it is shown that cultural background had little influence in how these people ultimately faired. Regardless of one's religion, nationality, social standing, or avowed friendship toward the Indians, everyone who came to western Virginia as a settler suffered in varying degrees because of Indian attacks. As war parties repeatedly raided settlements in western Virginia, the lucky escaped back across the mountains with their lives and perhaps their personal belongings intact. Those less fortunate suffered capture, torture, and death at the hands of angry villagers. As war parties repeatedly disrupted white efforts to occupy the region, the temporal aspects of the western Virginia frontier are revealed. Contrary to the "brief frontier" paradigm endorsed by Dunaway and Salstrom, it is seen that twice during the 1750 s and 1760 s, every last settler who moved to western Virginia was killed, captured, or driven off by Indian warriors. Consequently, the frontier in 1766 was no closer to being settled than it had been in 1750 .

By 1769 , we see the beginnings of a new effort by Euro-American settlers to occupy the western Virginia backcountry. It is this third attempt that ultimately succeeds in wresting control of the region from the Native Americans. Chapter five turns our attention to the household economies of the pioneer families who lived in western Virginia during this third and final phase. 
After all, not only is this dissertation concerned with the duration of the frontier experience, but it also seeks to understand the nature of that experience. To accomplish this goal, this chapter addresses the question: "Did the crude period of difficult living conditions exist for only a year or two as Mitchell, Dunaway, and Salstrom suggest, or did it persist longer?” In answering this question, the concept of "competency" is used as a model to help us to understand the economic dynamics of the individual pioneer households. This chapter shows that settlers used a combination of subsistence and commercial modes of production in their attempts to achieve comfortable standards of living. Through the use of forest farming, free range animal grazing, hunting, gathering, working at various skilled trades, and selling surplus farm and forest products, many settlers managed to maintain economically viable homesteads throughout the course of the later "Indian wars" that lasted until the close of the frontier in 1794.

Although many families in western Virginia achieved economically viable homesteads, by no means does this refute the idea that Indian-related violence prolonged the difficult period of living conditions. Chapter six explores how the continuing struggle between Indians and EuroAmericans adversely affected the ability of pioneer families to achieve competencies. Casualties in the form of injuries, captivities, and deaths all had a negative impact on the ability of frontier households to become competent. Likewise, damage to homes, property, and livestock also adversely affected the economic health of pioneer families. Backcountry settlements also suffered from depopulation as families fled the frontier outright or relocated to more secure sections of the frontier. In an attempt to defend themselves, frontiersmen formed militia companies to build fortifications, patrol the forest, and at times, take the battle to the Indians now mostly residing 
west of the Ohio River. Although their system of forts and militias proved instrumental in enabling the settlers to maintain a physical presence in western Virginia throughout the 1770s and 1780 s, it came at a price. Residing within the safety of a blockhouse or stockade made it difficult for a settler to clear land, plant crops, and to make improvements to his homestead. Likewise, the demands of militia duty diverted the labor of able-bodied men away from the construction of roads, bridges, buildings, and the development of industry. Thus, in order to survive, pioneer families had little choice but to sacrifice some of their economic security in favor of physical security. In other words, recurrent Indian attacks contributed to the settlers enduring an extended period of crude and difficult living condition on the western Virginia frontier.

In conclusion, although the colonial Appalachian frontier has been gone for two centuries, it still looms large in the American psyche. For many people, the "frontier experience" helps them to define who they are as Americans. Unfortunately, the "frontier" that they envision is oftentimes a mythical place colored by popular culture, Hollywood, and a sense of nostalgia. Visitors to colonial historic sites such as Prickett's Fort State Park frequently remark that they wish they "could live back then." If the truth be known, what they probably desire is greater simplicity in their present lives. To them, the frontier represents freedom from the complexities and problems of modernity. ${ }^{479}$ But as this study makes clear, life on the western Virginia frontier was anything but carefree and simple. In fact, colonial backwoodsmen faced many of the same problems that still trouble modern Americans. They suffered illnesses, moved away from friends and family, seldom had enough money, had transportation problems, and they had to pay their

${ }^{479}$ These observations are based on having spent six years as a costumed historical interpreter at Prickett's Fort State Park, the site of a reconstructed 1770s era frontier refuge fort. 
taxes. And on top of all that, they also lived in the midst of a protracted violent struggle against the Shawnees, Iroquois, and other Indians of the Ohio Valley and Old Northwest Territory. To one degree or another, the violence touched the lives of practically every pioneer family that lived in western Virginia from the mid-1750s through the mid-1790s. For those thousands of settlers who suffered death, destruction, and displacement at the hands of Indian warriors, the frontier experience was anything but brief. Hopefully this study has helped to illuminate an important formative period in the history of "West Virginia." 
Bibliography

\section{Primary Sources}

Manuscripts

Fairmont, West Virginia

Pricketts Fort Memorial Foundation Archives

J. Miles Prickett Papers

Militia at Prickett's Fort File

Nathaniel Cochrane Papers

Wilcox, William J. "History of Pricketts Fort." Unpublished Manuscript

Morgantown, West Virginia

West Virginia and Regional History Collection, West Virginia University

Haymond Family Papers

Luther Haymond Papers

Lyman C. Draper Manuscript Collection. Microfilm Edition (originals housed at the State Historical Society of Wisconsin, Madison, Wisconsin)

Moreland, James R. "The Early Cheat Mountain Iron Works.” Unpublished Manuscript

Roy Bird Cook Collection

Richmond, Virginia

Virginia State Archives

Fort Pitt Pay Book

Washington, D.C. 
National Archives and Records Administration

Revolutionary War Pension and Bounty Land Warrant Application Files, 1800-1900

Winchester, Virginia

Handley Library Archives

Jerry Cunningham Papers.

$\underline{\text { Courthouse Documents }}$

Augusta County, Virginia. County Court Records.

Mason County, Kentucky. County Court Records.

Monongalia County, West Virginia. Survey Book 1.

Randolph County, West Virginia. Will Book 1.

Westmoreland County, Pennsylvania. Deed Book A.

$\underline{\text { Newspapers }}$

The Fairmont Times, 1919

The Fairmont West-Virginian, 1919

$\underline{\text { Books }}$

Alder, Henry Clay. A History of Jonathan Alder: His Captivity and Life with the Indians. Akron, Ohio: University of Akron Press, 2002.

Asbury, Francis. The Journals and Letters of Francis Asbury. 3 vols. Nashville: Abingdon Press, 1958.

Bartlett, John Russell, ed. Letters of Roger Williams, 1632-1682. Providence: Narragansett Club, 1874. 
Black Hawk. Life of MA-KA-TAI-ME-SHE-KIA-KIAK or Black Hawk. 1834. Reprint. Iowa City, Iowa: State Historical Society of Iowa, 1932.

Bockstrock, Lloyd DeWitt. Virginia's Colonial Soldiers. Baltimore: Genealogical Publishing Company, 1988.

Brackinridge, H., ed. Indian Atrocities: Narratives of the Perils and Sufferings of Dr. Knight and John Slover. 1843. Reprint. Cincinnati: U. P. James, 1867.

Braddock, Edward. Major General Edward Braddock's Orderly Books, From February 26 to June 17, 1755. Cumberland, Md.: Will H. Lowdermilk, 1878.

Browning, Meshach. Forty-Four Years of the Life of a Hunter. Winston-Salem, N. C.: Winston Printing Company, 1942.

Butterfield, C. W. The Washington-Crawford Letters Being the Correspondence between George Washington and William Crawford from 1767-1781. Cincinnati: Robert Clarke, 1877.

Chalkley, Lyman. Chronicles of the Scotch-Irish Settlement in Virginia. 3 vols. Baltimore: Baltimore Genealogical Publishing Co., 1966.

Commons, John R., Ulrich B. Phillips, Eugene A. Gilmore, Helen L. Sumner, and John B. Andrews, eds. A Documentary History of American Industrial Society. Vol. 2, Plantation and Frontier. New York: Russell and Russell, 1958.

Cresswell, Nicholas. The Journal of Nicholas Cresswell, 1774-1777. New York: Dial, 1924.

Crumrine, Boyd. The County Court for the District of West Augusta, Va., Held at Augusta Town, Near Washington, 1776-1777. Washington, D.C.: Washington Historical Society, 1910.

Darlington, William M. Christopher Gist's Journals with Historical, Geographical, and Ethnological Notes and Biographies of His Contemporaries. Pittsburgh: J. R. Weldin, 1893.

Doddridge, Joseph. Notes on the Settlement and Indian Wars. 1912. Reprint. Parsons, W. Va.: McClain, 1989.

Drimmer, Frederick, ed. Captured by the Indians: 15 Firsthand Accounts, 1750-1870. New York: Dover Publications, 1961.

Edgar, Matilda. Ten Years of Upper Canada in Peace and War, 1805-1815; Being The Ridout Letters. Toronto: William Briggs, 1890.

Filson, John. The Discovery, Settlement, and Present State of Kentucke. 1784. Reprint. Ann 
Arbor: University Microfilms, 1966.

Fitzpatrick, John C., ed. The Diaries of George Washington, 1748-1799. Vol. 1. Boston: Houghton Mifflin, 1925.

The Writings of George Washington from the Original Manuscript Sources. Washington, D. C.: Government Printing Office, 1931.

Hall, Wilmer L., ed. Executive Journals of the Council of Colonial Virginia. Vol. 5. Richmond: Virginia State Library, 1945.

Hamilton, Stanislaus Murray, ed. Letters to Washington and Accompanying Papers, vol. 2, 1756 1758. Boston: Houghton, Mifflin, 1899.

Harriot, Thomas. A Briefe and True Report of the New Found Land of Virginia. New York: Dover Publications, 1972.

Hazard, Samuel, ed., Minutes of the Provincial Council of Pennsylvania [spine title: Colonial Records]. Vol. 3. Harrisburg: Pennsylvania, 1852.

. Pennsylvania Archives, Philadelphia: Joseph Severns, 1853.

Heckewelder, John. An Account of the History, Manners, and Customs of the Indian Nations Who Once Inhabited Pennsylvania and the Neighboring States. Philadelphia: Philosophical Society, 1819.

. The Travels of John Heckewelder in Frontier America. Edited by Paul A. W. Wallace. Pittsburgh: University of Pittsburgh Press, 1985.

Hening, William Waller, ed. The Statutes at Large; Being a Collection of All the Laws of Virginia, 1619-1792. 13 vols. Richmond: 1809-23.

Hulbert, Archer Butler, ed. Pioneer Roads and Experiences of Travelers, Volume II, Vol. 12, Historic Highways of America. Cleveland: Arthur H. Clark Company, 1904.

Washington and the West: Being George Washington's Diary of September, 1784. Kept during His Journey into the Ohio Basin in the Interest of a Commercial Union between the Great Lakes and the Potomac River. New York: Century, 1905.

Jefferson, Thomas. Notes on the State of Virginia. Edited by William Pedan. New York: W. W. Norton, 1954.

Johnson, William. The Papers of Sir William Johnson. Vol. 3. New York: University of the State 
of New York Division of Archives and History, 1921.

Jones, David. A Journal of Two Visits Made to Some Nations of Indians on the West side of the River Ohio, in the Years 1772 and 1773. Burlington: n.p, 1774.

Kalm, Peter. Peter Kalm's Travels in North America: The English Version of 1770. Edited by Adolph B. Benson. New York: Dover Publications, 1966.

Kappler, Charles J., ed. Indian Treaties, 1778-1883. New York: Interland Publishing, 1972.

Kellogg, Louise Phelps, ed. Frontier Advance on the Upper Ohio, 1778-1779. Madison:

Wisconsin Historical Society, 1916.

King James I. "A Speech to the Lords and Commons of the Parliament at White-Hall (1610)." In Divine Right and Democracy: An Anthology of Political Writing in Stuart England. Edited by David Wootton. London: Penguin Books, 1986.

Kingsbury, Susan M., ed. Records of the Virginia Company of London. Washington: Government Printing Office, 1933.

Labaree, Leonard W., ed. The Papers of Benjamin Franklin. Vol. 11. New Haven: Yale University Press, 1967.

Lamech and Agrippa. Chronicon Ephratense; A History of the Community of Seventh Day Baptists at Ephrata, Lancaster County, Penn'a. Translated by J. Max Hark. Lancaster, Pa.: S. H. Zahm, 1889.

[Lederer, John]. The Discoveries of John Lederer. Edited by William P. Cumming. Charlottesville: University Press of Virginia, 1958.

Lewis, Ronald L. and John C. Hennen Jr., eds. West Virginia: Documents in the History of a Rural-Industrial State. Dubuque, Iowa: Kendall/Hunt, 1991.

Lewis, Thomas. The Fairfax Line: Thomas Lewis's Journal of 1746. New Market, Va.: Henkel Press, 1925.

Loskiel, George Henry. History of the Mission of the United Brethren among the Indians in North America. London: Printed for the Brethren's Society for the Furtherance of the Gospel, 1794.

McIlwaine, John P. and John P. Kennedy, eds., Journals of the House of Burgesses of Virginia, 1758-1761. Richmond: Colonial Press, 1908. 
Myers, Albert Cook, ed. Narratives of Early Pennsylvania, West New Jersey, and Delaware, 1630-1710. New York: Barnes and Noble, 1953.

O'Callaghan, E. B., ed., Documents Relative to the Colonial History of the State of New York. Albany: Weed, Parsons, 1853-1887.

Palmer, W. P., ed. Calendar of Virginia State Papers and Other Manuscripts. 11 vols. Richmond: State of Virginia, 1875-93.

Post, Christian Frederick. "Two Journals of Western Tours." In Early Western Travels, 17481846. Vol. 1, Edited by Reuben Gold Thwaites. Cleveland: Arthur H. Clark, 1904.

Presbyterian Church in the United States. Records of the Presbyterian Church in the United States (Philadelphia: Presbyterian Board of Publication, 1841.

Schoepf, Johann David. Travels in the Confederation, 1783-1784. Vol. 1. Edited by Alfred J. Morrison. New York: Burt Franklin, 1986.

Schreiner-Yantis, Netti. The Personal Property Tax Lists for the Year 1787 for Greenbrier County, Virginia. Springfield, Va.: Genealogical Books in Print, 1987.

. The Personal Property Tax Lists for the Year 1787 for Harrison County, Virginia. Springfield, Va.: Genealogical Books in Print, 1987.

. The Personal Property Tax Lists for the Years 1786, 1787 (partial) and 1788 for Monongalia County, Virginia. Springfield, Va.: Genealogical Books in Print, 1987.

. The Personal Property Tax Lists for the Year 1787 for Randolph County, Virginia. Springfield, Va.: Genealogical Books in Print, 1987.

Shepherd, Samuel, ed., The Statutes at Large of Virginia, From October Session 1792, to December Session 1806, Inclusive. Vol. 1. Richmond: 1835.

Smyth, J. F. D. A Tour of the United States of America, Vol. 1. 1774. Reprint. New York: Arno Press, 1968.

Spencer, O. M. The Indian Captivity of O. M. Spencer. Edited by Milo M. Quaife. 1838. Reprint. Chicago: R. R. Donnelly, 1917.

Stevens, Sylvester K. and Donald H. Kent, eds. The Papers of Col. Henry Bouquet, series 21650, pt. 2. Harrisburg: Pennsylvania Historic Commission, 1943.

Stuart, John. Memoir of Indian Wars, and Other Occurrences. 1833. Reprint. Parsons, W.Va.: 


\section{McClain, 1971.}

. "Memorandum, 1798, July 15 $5^{\text {th }}$." In Dayton, Ruth Woods Dayton. Greenbrier Pioneers and Their Homes. Charleston, W. Va.: West Virginia Publishing, 1942.

Sweet, William Warren, ed., The Methodists. Vol. 4, Religion on the American Frontier, 17831840: A Collection of Source Materials. Chicago: University of Chicago Press, 1946.

Thwaites, Reuben G., ed. Early Western Travels. 32 vols. Cleveland: Arthur H. Clark Co., 19047.

. The Jesuit Relations and Allied Documents. Vol. 59. Cleveland: Burrows Brothers Company, 1900.

Thwaites, Reuben G. and Louise P. Kellogg, eds. Documentary History of Dunmore's War, 1774. Madison: Wisconsin Historical Society, 1905.

. Frontier Defense on the Upper Ohio, 1777-1778. Madison: Wisconsin Historical Society, 1912.

. Frontier The Revolution on the Upper Ohio, 1775-1777. Madison: Wisconsin Historical Society, 1908.

Toothman, Rick. Monongalia County (West Virginia Deedbook Records, 1784-1810, (Old Series Volumes 1-4). Bowie, Md.: Heritage Books, 1994.

Toulmin, Harry. The Western Country in 1793: Reports on Kentucky and Virginia. Edited by M. Tinling and G. C. David. San Marino, Calif.: Castle Press, 1948.

Trowbridge, C.C. Shawnese Traditions., Edited by Vernon Kinietz and E. W. Voegelin. Occasional Contributions from the Museum of Anthropology, University of Michigan, no. 9. Ann Arbor: University of Michigan Press, 1939.

Virginia. Index of Acts of the General Assembly of the Commonwealth of Virginia, 1912-1959. Richmond: Commonwealth of Virginia Department of Purchases and Supply, 1959.

Walker, Thomas. Journal of an Exploration in the Spring of the Year 1750. Edited by William C. Rives. Boston: Little, Brown, and Company, 1888.

Washington, George. The Journal of Major George Washington. Williamsburg: Colonial Williamsburg Foundation, 1959.

Wraxall, Peter. Abridgement of the Indian Affaires Contained in Four Folio Volumes, 
Transacted in the Colony of New York, From the Year 1678 to the Year 1751. Edited by Charles H. Mcllwain. Cambridge: Harvard University Press, 1915.

Zeisberger, David. David Zeisberger's History of the Northern American Indians., Edited by Archer Butler Hulbert and William Nathaniel Schwarze. Columbus: Ohio State Archaeological and Historical Society, 1910.

Zinn, Melba Pender. Monongalia County, (West) Virginia: Records of the District, Superior, and County Courts. Vol. 1, 1776-1799. Bowie, Md.: Heritage Books, 1990.

\section{$\underline{\text { Secondary Sources }}$}

$\underline{\text { Books }}$

Abernathy, Thomas Perkins. Western Lands and the American Revolution. New York: Russell and Russell, 1959.

. Three Virginia Frontiers. 1940. Reprint. Gloucester, Mass.: Peter Smith, 1962.

Alberts, Robert C. A Charming Field for an Encounter: The Story of George Washington's Fort Necessity. Washington, D.C.: National Park Service, 1975.

Alford, Thomas Wildcat. Civilization: As Told to Florence Drake. Norman: University of Oklahoma Press, 1936.

Alvord, Clarence Walworth, and Lee Bidgood. The First Explorations of the Trans-Allegheny Region by the Virginians, 1650-1674. Cleveland: Arthur H. Clark Company, 1912.

Ambler, Charles Henry. A History of Transportation in the Ohio Valley. Glendale, Calif.: Arthur H. Clark, 1931.

. George Washington and the West. Chapel Hill: University of North Carolina Press, 1936. . Sectionalism in Virginia from 1776 to 1861. New York: Russell and Russell, 1964.

Ambler, Charles Henry and Festus P. Summers. West Virginia: The Mountain State. New York: Prentice-Hall, 1940.

Anderson, Fred. Crucible of War: The Seven Years = War and the Fate of Empire in British North America, 1754-1766. New York: Vintage Books, 2000.

Aptheker, Herbert. American Negro Slave Revolts. New York: International Publishers, 1963. 
Axtell, James. ed., The Indian Peoples of Eastern America: A Documentary History of the Sexes. New York: Oxford University Press, 1981).

. The Invasion Within: The Contest of Cultures in Colonial North America. New York: Oxford University Press, 1985.

Bailey, Kenneth P. The Ohio Company of Virginia and the Westward Movement, 1748-1792: A Chapter in the History of the Colonial Frontier. Glendale, Calif.: Arthur H. Clark, 1939.

Bailyn, Bernard. The Peopling of British North America: An Introduction. New York: Alfred A. Knopf, 1986.

Bailyn, Bernard and Philip D. Morgan., eds. Strangers Within the Realm: Cultural Margins of the First British Empire. Chapel Hill: University of North Carolina Press, 1991.

Baldwin, Leland D. Whiskey Rebels: The Story of a Frontier Uprising. Pittsburgh: University of Pittsburgh Press, 1939.

Batteau, Allen W. The Invention of Appalachia. Tucson: University of Arizona Press, 1990.

Baugh, Timothy G. and Jonathan E. Ericson, eds. Prehistoric Exchange Systems in North America. New York: Plenum Press, 1994.

Beeman, Richard R. The Evolution of the Southern Backcountry: A Case Study of Lunenburg County, Virginia, 1746-1832. Philadelphia: University of Pennsylvania Press, 1984.

Belue, Ted Franklin. The Long Hunt: Death of the Buffalo East of the Mississippi River. Mechanicsburg, Penn.: Stackpole Books, 1996.

Billings, Dwight B. and Kathleen M. Blee. The Road to Poverty: The Making of Wealth and Hardship in Appalachia. Cambridge: Cambridge University Press, 2000.

Billington, Ray Allen. Westward Expansion: A History of the American Frontier. New York: Macmillan Publishing, 1974.

Bining, Arthur Cecil. Pennsylvania Iron Manufacture. Harrisburg: Pennsylvania Historic Commission, 1938.

Bittinger, Emmert F. Allegheny Passage: Churches and Families, West Marva District, Church of the Brethren 1752-1990. Camden, Maine: Penobscot Press, 1990.

Boback, John M. Pricketts Fort: A Bastion in the Wilderness. Fairmont, W. Va.: Pricketts Fort 
Memorial Foundation, 2005.

Brackenridge, H. M. History of the Western Insurrection in Western Pennsylvania Commonly Called the Whiskey Insurrection. Pittsburgh: W. S. Shane, 1859.

Brand, Franklin Marion. The Wade Family: Monongalia County, Virginia. Morgantown, W. Va.: N.p., 1927.

Breckinridge, Mary. Wide Neighborhoods: Story of the Frontier Nursing Service. Lexington: University of Kentucky Press, 1981.

Briceland, Alan Vance. Westward from Virginia: The Exploration of the Virginia-Carolina Frontier, 1650-1710. Charlottesville: University Press of Virginia, 1987.

Brown, Alexander. The Genesis of the United States. Boston: Houghton, Mifflin and Company, 1890.

Brown, Stephen W. Voice of the New West: John Jackson His Life and Times. Macon, Ga.: Mercer University Press, 1985.

Buck, Solon J. and Elizabeth Hawthorn Buck. The Planting of Civilization in Western Pennsylvania. Pittsburgh: University of Pittsburgh Press, 1939.

Burns, Rex. Success in America: The Yeoman Dream and the Industrial Revolution. Amherst: University of Massachusetts Press, 1976.

Callahan, James Morton. Semi-Centennial History of West Virginia. Charleston, W. Va.: SemiCentennial Commission of West Virginia, 1913.

Callender, Charles. "Shawnee." In Northeast. Vol. 15 of Handbook of North American Indians. Washington: Smithsonian Institution, 1978.

Calloway, Colin G. The American Revolution in Indian Country: Crisis and Diversity in Native American Communities. New York: Cambridge University Press, 1995.

New Worlds for All: Indians, Europeans, and the Remaking of Early America. Baltimore: Johns Hopkins University Press, 1997.

Campbell, John C. The Southern Highlander and His Homestead. Lexington: University Press of Kentucky, 2004.

Caruso, John Anthony. The Appalachian Frontier: America's First Surge Westward. Indianapolis: Bobbs-Merrill Company, 1959. 
Cayton, Andrew R. L. "Marietta and the Ohio Company." In Appalachian Frontiers: Settlement, Society, and Development in the Preindustrial Era. Edited by Robert D. Mitchell. Lexington: University Press of Kentucky, 1990.

Clark, Christopher. The Roots of Rural Capitalism: Western Massachusetts, 1780-1860. Ithaca: Cornell University Press, 1990.

Clark, Jerry E. The Shawnee. Lexington: University Press of Kentucky, 1993.

Clarkson, Roy B. Tumult on the Mountains: Lumbering in West Virginia, 1770-1920. Parsons, W. Va.: McClain, 1964.

Cook, Jeffrey B. Pricketts Fort and the Pioneers of Western Virginia: A Finding Aid. Fairmont: Prickett's Fort Memorial Foundation, n.d.

Cook, Roy Bird. Washington's Western Lands. Strasburg, Va.: Shenandoah Publishing House, 1930.

Coonts, Violet Gadd. The Western Waters: Early Settlers of Eastern Barbour County, West Virginia. Denver: Stephen P. Coonts, 1991.

Core, Earl L. Chronicles of Core. 3d ed. Parsons, W. Va.: McClain, 2002. . The Monongalia Story: A Bicentennial History. 5 vols. Parsons, W.Va.: McClain, 1974. . Vegetation of West Virginia. Parsons, W. Va.: McClain, 1966.

Cranmer, Gibson Lamb, ed. History of Wheeling City and Ohio County, West Virginia and Representative Citizens. Chicago: Biographical Publishing Company, 1902.

Cress, Lawrence Delbert. Citizens in Arms: The Army and the Militia in American Society to the War of 1812. Chapel Hill: University of North Carolina Press, 1982.

Cronin, William. Changes in the Land: Indians, Colonists, and the Ecology of New England. New York: Hill and Wang, 1983.

Crosby, Alfred W. Ecological Imperialism: The Biological Expansion of Europe, 900-1900. Cambridge: Cambridge University Press, 1986.

Cunningham, Jr., Noble E. In Pursuit of Reason: The Life of Thomas Jefferson. New York: Ballatine Books, 1987. 
Davis, Dorothy. History of Harrison County West Virginia. Parsons, W. Va.: McClain Printing Company, 1970.

Dayton, Ruth Woods. Greenbrier Pioneers and Their Homes Charleston, W. Va.: West Virginia Publishing, 1942.

De Hass, Wills. History of the Early Settlement and Indian Wars of Western Virginia. 1851. Reprint. Parsons, W.Va.: McClain, 1989.

DeMay, John A. The Settlers' Forts of Western Pennsylvania. Apollo, Pa.: Clossen Press, 1997.

Dobb, Maurice. Studies in the Development of Capitalism. New York: International Publishers, 1947.

Downes, Randolph C. Council Fires on the Upper Ohio: A Narrative of Indian Affairs in the Upper Ohio Valley until 1795. Pittsburgh: University of Pittsburgh Press, 1968.

Dunaway, Wilma A. The First American Frontier: Transition to Capitalism in Southern Appalachia, 1700-1860. Chapel Hill: University of North Carolina Press, 1996.

Dunn, Durwood. Cades Cove: The Life and Death of a Southern Appalachian Community, 1818-1937. Knoxville: University of Tennessee Press, 1988.

Dunnington, George A. History and Progress of the County Marion, West Virginia. 1880. Reprint. Morgantown, W.Va.: Morgantown Printing and Binding, 1992.

Durie, Alastair J. The Scottish Linen Industry in the Eighteenth Century. Edinburgh, Scotland: John Donald Publishers, c. 1979.

Durnbaugh, Donald F., ed. The Brethren in Colonial America: A Source Book on the Transplantation and Development of the Church of the Brethren in the Eighteenth Century. Elgin, Ill.: Brethren Press, 1967.

Eckert, Allan W. A Sorrow in Our Heart: The Life of Tecumseh. New York: Bantam Books, 1992.

Edmunds, R. David. Tecumseh and the Quest for Indian Leadership. New York: Harper Collins, 1984.

Ellis, Franklin. History of Fayette County, Pennsylvania. Philadelphia: L. H. Everts, 1882.

Ergood, Bruce and Bruce E. Kuhre, eds. Appalachia: Social Context Past and Present. Dubuque, Iowa: Kendall/Hunt, 1983. 
Faragher, John Mack. Daniel Boone: The Life and Legend of an American Pioneer. New York: Henry Holt and Company, 1992.

Fischer, David Hackett. Albion's Seed: Four British Folkways in America. New York, Oxford University Press, 1989.

Ford, Thomas R., ed. The Southern Appalachian Region: A Survey. Lexington: University of Kentucky Press, 1962.

Fort Ligonier Association et al. War for Empire in Western Pennsylvania. Ligonier, Pa.: Fort Ligonier Association, 1993.

Fox, Jr., John. The Trail of the Lonesome Pine. New York: Charles Scribner's Sons, 1908.

Freund, Rudolf. "Military Bounty Lands and the Origins of the Public Domain." In The Old Northwest: Studies in Regional History, 1787-1910, edited by Harry N. Scheiber. Lincoln: University of Nebraska Press, 1969.

Getis, Arthur, Judith Getis, and Jerome D. Fellmann. Introduction to Geography, 6th ed. Boston: McGraw-Hill Higher Education, 1998.

Ginzburg, Carlo. The Cheese and the Worms: The Cosmos of a Sixteenth Century Miller. Baltimore: Johns Hopkins University Press, 1980.

Greenblatt, Stephen. Marvelous Possessions: The Wonder of the New World. Chicago: University of Chicago Press, 1991.

Griffin, James B. "Late Prehistory of the Ohio Valley." In Northeast. Vol. 15, Handbook of North American Indians. Washington, D.C.: Smithsonian Institution, 1978.

Griswold, A. Whitney. Farming and Democracy. New Haven: Yale University Press, 1948.

Guilday, John E. Biological and Archeological Analysis of Bones from a 17th Century Indian Village (46 PU 31), Putnam County, West Virginia. Morgantown: West Virginia Geological and Economic Survey, 1971.

Hahn, Steven and Jonathan Prude, eds. The Countryside in the Age of Capitalist Transformation: Essays in the Social History of Rural America. Chapel Hill: University of North Carolina Press, 1985.

Hale, John P. Trans-Allegheny Pioneers. 3d ed. Radford, Va.: Roberta Ingles Steele, 1971. 
Hartley, Dorothy. Lost Country Life. New York: Pantheon Books, 1979.

Hayak, F. A., ed. Capitalism and the Historians. Chicago: University of Chicago Press, 1954.

Haymond, Henry. Historical Reference to Pricketts' Fort and Its Defenders. . . . N.p., n.d. . History of Harrison County West Virginia. Morgantown, W. Va.: Acme, 1910.

Heidenreich, Conrad E. "Huron." In Northeast. Vol. 15, Handbook of North American Indians. Washington, D.C.: Smithsonian Institution, 1978.

Henlein, Paul C. Cattle Kingdom in the Ohio Valley, 1783-1860. Lexington: University of Kentucky Press, 1959.

Hintzman, William. A Sketchbook of the Border Wars of the Upper Ohio Valley, 1769-1794: Conflicts and Resolutions. Manchester, Conn.: Precision Shooting, 1999.

Hoffman, Joseph E., ed. Marion County Centennial Yearbook, 1863-1963. Fairmont, W.Va.: Marion County Centennial Committee, [1963].

Hofstra, Warren R., ed. George Washington and the Virginia Backcountry. Madison: Madison House, 1998.

. The Planting of New Virginia: Settlement and Landscape in the Shenandoah Valley. Baltimore: Johns Hopkins University Press, 2004.

Howard, James H. Shawnee!: The Ceremonialism of a Native American Indian Tribe and Its Cultural Background. Athens: Ohio University Press, 1981.

Hubbard-Brown, Janet. The Shawnee. New York: Chelsea House, 1995.

Hunt, George T. The Wars of the Iroquois: A Study in Intertribal Trade Relations. Madison: University of Wisconsin Press, 1940.

Hurt, R. Douglas. Indian Agriculture in America: Prehistory to Present. Lawrence: University Press of Kansas, 1987.

Innes, Stephen., ed. Work and Labor in Early America. Chapel Hill: University of North Carolina Press, 1988.

Isaac, Rhys. The Transformation of Virginia, 1740-1790. New York: W. W. Norton, 1982.

Jacob, John Jeremiah. A Biographical Sketch of the Life of the Late Captain Michael Cresap. 
Parsons, W. Va.: McClain, 1971.

James, Alfred P. The Ohio Company: Its Inner History. Pittsburgh: University of Pittsburgh Press, 1959.

Jennings, Francis. The Ambiguous Iroquois Empire: The Covenant Chain Confederation of Indian Tribes with English Colonies from Its Beginnings to the Lancaster Treaty of 1744. New York: W. W. Norton, 1984.

. Empire of Fortune: Crowns, Colonies, and Tribes in the Seven Years War in America. New York: Norton, 1988.

. The Invasion of America: Indians, Colonialism, and the Cant of Conquest. New York: W. W. Norton, 1975.

Johnson, Patricia Givens. General Andrew Lewis of Roanoke and Greenbrier. Blacksburg, Va.: Southern Printing Company, 1980.

1983. . James Patton and the Appalachian Colonists. 2d ed. Pulaski, Va.: Edmonds Printing,

Johnston, Ross B., comp. and ed. West Virginians in the American Revolution. Parkersburg, W. Va.: West Augusta Historical and Genealogical Society, 1959.

Jones, Dorothy V. License for Empire: Colonialism by Treaty in Early America. Chicago: University of Chicago Press, 1982.

Josephy, Jr., Alvin M. America in 1492: The World of the Indian Peoples before the Arrival of Columbus. New York: Alfred A. Knopf, 1993.

Kantorowicz, Ernst H. The King's Two Bodies: A Study in Mediaeval Political Theology. Princeton: Princeton University Press, 1957.

Kendall-Lowther, Minnie. Friendship Hill: Home of Albert Gallatin. Morgantown, W. Va.: Friendship Hill Association, 1928.

Kenton, Edna. Simon Kenton; His Life and Period, 1755-1836. Garden City, N. Y.: Doubleday, Doran, 1930.

Kephart, Horace. Our Southern Highlanders. New York: Outing Publishing Company, 1913.

Kulikoff, Allan. The Agrarian Origins of American Capitalism. Charlottesville: University Press of Virginia, 1992. 
. Tobacco and Slaves: The Development of Southern Cultures in the Chesapeake, 16801800. Chapel Hill: University of North Carolina Press, 1986.

Lamar, Howard and Leonard Thompson., eds. The Frontier in History: North America and Southern Africa Compared. New Haven: Yale University Press, 1981.

Lambert, Oscar Doane. West Virginia and Its Government. Boston: D.C. Heath, 1951.

Lemon, James T. The Best Poor Man's Country: A Geographical Study of Early Southeastern Pennsylvania. Baltimore: Johns Hopkins Press, 1972.

Lepore, Jill. The Name of War: King Philip's War and the Origins of American Identity. New York: Vintage Books, 1998.

Lewis, Johanna Miller . Artisans in the North Carolina Backcountry. Lexington: University Press of Kentucky, 1995.

Lewis, Ronald L. Transformation of the Appalachian Countryside: Railroads, Deforestation, and Social Change in West Virginia, 1880-1920. Chapel Hill: University of North Carolina Press, 1998.

Lewis, Ronald L. and John C. Hennen, Jr., eds. West Virginia History: Critical Essays on the Literature. Dubuque, Iowa: Kendall/Hunt Publishing Company, 1993.

Lewis, Virgil A. A History of the Battle of Point Pleasant. Charleston, W.Va.: Tribune Printing Company, 1909.

. The Soldiery of West Virginia. Charleston, W.Va.: News-Mail Company, 1910.

. Second Biennial Report of the Department of Archives and History of the State of West Virginia. N.p.n.d., [1908?].

Leyburn, James G. The Scotch-Irish: A Social History. Chapel Hill: University of North Carolina Press, 1962.

Lodge, Henry Cabot. Short History of the English Colonies in America. New York: Harper and Brothers, 1881.

MacMaster, Richard K. "The Cattle Trade in Western Virginia, 1760-1830.” In Appalachian Frontiers: Settlement, Society, and Development in the Preindustrial Era. Edited by Robert D. Mitchell. Lexington: University Press of Kentucky, 1990. 
Marx, Leo. The Machine in the Garden: Technology and the Pastoral Ideal in America. New York: Oxford University press, 1964.

Maxwell, Hu. The History of Randolph County, West Virginia. 1898. Reprint. Parsons, W.Va.: McClain, 1991.

Mayer-Oakes, William J. Prehistory of the Upper Ohio Valley: An Introductory Study. Pittsburgh: Carnegie Museum, 1955.

McAllister, Jean Graham. A Brief History of Bath County, Virginia. Staunton: McClure, 1920.

McBride, W. Steohen, Kim Arbogast McBride, and Greg Adamson. Frontier Forts in West Virginia: Historical and Archaeological Explorations. Charleston: West Virginia Division of Culture and History, 2003.

McConnell, Michael N. A Country Between: The Upper Ohio Valley and Its Peoples, 1724-1774. Lincoln: University of Nebraska Press, 1992.

McDaniel, L'lora C. The History and Genealogy of the Ancestors of John M. Tomey and Catharine M. Prickett and Their Descendants. N.p., n.d.

McMichael, Edward V. Introduction to West Virginia Archeology. 2d ed., rev. Morgantown: West Virginia Geological and Economic Survey, 1968.

McNeel, William P. "Pocahontas County." In History of Pocahontas County, West Virginia. Marlinton, W. Va.: Pocahontas County Historical Society, 1981.

McNeill, G. D. Tales of Pocahontas County. Parsons, W. Va.: McClain, 1991.

McRaven, Charles. Building \& Restoring the Hewn Log House. 2d ed. Cincinnati: Betterway Books, 1994. Building with Stone. Pownal, Vt.: Garden Way Publishing, 1989.

McWhiney, Grady. Cracker Culture: Celtic Ways in the Old South. Tuscaloosa, Ala.: University of Alabama Press, 1988.

McWhorter, Lucullus Virgil. The Border Settlers of Northwestern Virginia, from 1768 to 1795. 1915. Reprint. Parsons, W. Va.: McClain, 2000.

Mitchell, Robert D. ed. Appalachian Frontiers: Settlement, Society, and Development in the Preindustrial Era. Lexington: University Press of Kentucky, 1991. 
. Commercialism and Frontier: Perspectives on the Early Shenandoah Valley.

Charlottesville: University Press of Virginia, 1977.

Morgan, John. "Log House Construction in Blount County, East Tennessee." In Appalachian Frontiers: Settlement, Society, and Development in the Preindustrial Era. Edited by Robert D. Mitchell. Lexington: University Press of Kentucky, 1990.

Morton, Frederic. The Story of Winchester in Virginia: The Oldest Town in the Shenandoah Valley. Strasburg, Va.: Shenandoah Publishing House, 1925.

Morton, Oren F. Annals of Bath County, Virginia. Staunton, Va: McClure, 1917.

Morton, Richard L. Colonial Virginia. 2 vols. Chapel Hill: University of North Carolina Press, 1960.

Nabokov, Peter and Dean Snow. "Farmers of the Woodlands." In America in 1492: The World of the Indian Peoples before the Arrival of Columbus. edited by Alvin M. Josephy, Jr. New York: Alfred A. Knopf, 1993.

North, Douglas. Structure and Change in Economic History. New York: Norton, 1981.

Odle, Mark. "Tools and Techniques of Bark Tanning." In The Book of Buckskinning VII. edited by William H. Scurlock. Texarkana, Tex.: Scurlock Publishing, 1995.

O'Meara, Walter. Guns at the Forks. Englewood Cliffs, N.J.: Prentice-Hall, 1965.

Perkins, Elizabeth A. Border Life: Experience and Memory in the Revolutionary Ohio Valley. Chapel Hill: University of North Carolina Press, 1998.

Pocahontas County Historical Society. History of Pocahontas County West Virginia 1981. Marlinton, W.Va.: Pocahontas County Historical Society, 1981.

Pollock, Frederick and Robert Samuel Wright. An Essay on Possession in the Common Law. Oxford: Clarendon Press, 1988.

Price, William T. Historical Sketches of Pocahontas County, West Virginia. Marlinton, W.Va: Price Brothers, 1901.

Pritts, Kim Derek. Ginseng: How to Find, Grow, and Use America's Gold. Mechanicsburg, Pa.: Stackpole Books, 1995.

Pudup, Mary Beth, Dwight B. Billings, and Altina L. Waller., eds. Appalachia in the Making: The Mountain South in the Nineteenth Century. Chapel Hill, N.C.: University of North 
Carolina Press, 1995.

Puglisi, Michael J., ed. Diversity and Accommodation: Essays on the Cultural Composition of the Virginia Frontier. Knoxville: University of Tennessee Press, 1997.

Ragsdale, Bruce A. The Planters' Republic: The Search for Economic Independence in Revolutionary Virginia. Madison, Wis.: Madison House, 1996.

Randolph, Corliss Fitz. A History of Seventh Day Baptists in West Virginia. Plainfield, N.J.: American Sabbath Tract Society, 1905.

Rasmussen, Barbara. Absentee Landowning and Exploitation in West Virginia, 1760-1920. Lexington: University Press of Kentucky, 1994.

Rice, Otis K. The Allegheny Frontier: West Virginia Beginnings, 1730-1830. Lexington: University Press of Kentucky, 1970. . A History of Greenbrier County. Lewisburg, W.Va.: Greenbrier Historical Society, 1986.

Rice, Otis K. and Stephen W. Brown. West Virginia: A History. 2d ed. Lexington, University Press of Kentucky, 1993.

Richter, Daniel K. The Ordeal of the Longhouse: The Peoples of the Iroquois League in the Era of European Colonization. Chapel Hill: University of North Carolina Press, 1992.

Riforgiato, Leonard R. Missionary of Moderation: Henry Melchior Muhlenberg and the Lutheran Church in English America. Lewisburg, Penn.: Bucknell University Press, 1980.

Rogers, Jr., Samuel W. In My Father's House: The Life and Times of Chief John Logan. Logan, W. Va.: Radarta, 1990.

Salstrom, Paul. Appalachia's Path to Dependency: Rethinking a Region's Economic History, 1730-1940. Lexington: University Press of Kentucky, 1994.

. "Economic History of West Virginia: A Critical Essay." In West Virginia History: Critical Essays on the Literature, edited by Ronald L. Lewis and John C. Hennen, Jr. Dubuque, Iowa: Kendall/Hunt, 1993.

Samerson, Tyndall V., comp. The Open Sesame Question and Answer Book on West Virginia (St. Mary's, W. Va.: West Virginia Club Concern, 1955.

Schaff, Gregory. Wampum Belts and Peace Trees: George Morgan, Native Americans, and Revolutionary Diplomacy. Golden, Colo.: Fulcrum Publishing, 1990. 
Schwaegel, Bruce. "Brain Tanning Buckskin.” In The Book of Buckskinning III, edited by William H. Scurlock. Texarkana, Tex.: Rebel Publishing, 1985.

Seed, Patricia. Ceremonies of Possession in Europe's Conquest of the New World, 1492-1640. New York: Cambridge University Press, 1995.

Sellers, Charles. The Market Revolution: Jacksonian America, 1815-1846. New York: Oxford University Press, 1991.

Semple, Ellen Churchill. American History and Its Geographic Conditions. Boston: Houghton, Mifflin and Company, 1903.

Shapiro, Henry D. Appalachia on Our Mind: The Southern Mountains and Mountaineers in the American Consciousness, 1870-1920. Chapel Hill: University of North Carolina Press, 1978.

Sheridan, Richard B. Sugar and Slavery: An Economic History of the British West Indies, 16231775. Baltimore: Johns Hopkins University Press, 1973.

Sipe, C. Hale. The Indian Wars of Pennsylvania. Lewisburg, Penn.: Wennawoods Publishing, 1999.

Slaughter, Thomas P. The Whiskey Rebellion: Frontier Epilogue to the American Revolution. New York: Oxford University Press, 1986.

Smith, Henry Nash. Virgin Land: The American West as Symbol and Myth. Cambridge: Harvard University Press, 1950.

Sosin, Jack M. The Revolutionary Frontier, 1763-1783. New York: Holt, Rinehart and Winston, 1967.

Whitehall and the Wilderness: The Middle West in British Colonial Policy, 1760-1775. Lincoln: University of Nebraska Press, 1961.

Stealey III, John E. The Antebellum Kanawha Salt Business and Western Markets. Lexington: University Press of Kentucky, 1993.

Steele, Ian K., Warpaths: Invasions of North America. New York: Oxford University Press, 1994.

Swem, Earl G. and John W. Williams. A Register of the General Assembly of Virginia, 17761918 and of the Constitutional Conventions. Richmond: n.p., 1918. 
Taylor, George Rogers., ed. The Turner Thesis: Concerning the Role of the Frontier in American History. $3^{\mathrm{d}}$ ed., ed. Lexington, Mass.: D.C. Heath, 1972.

Thernstrom, Stephan. A History of the American People. Vol. 1, To 1877. New York: Harcourt Brace Jovanovich, 1984.

Thom, James Alexander. Panther in the Sky. New York: Ballantine Books, 1989.

Thompson, Carl N., comp. Historical Collections of Brown County, Ohio. Piqua, Ohio: Hammer Graphics, 1969.

Thompson, James Westfall. A History of Livestock Raising in the United States, 1607-1860. Agricultural History Series, no. 5. 1942. Reprint. Wilmington, Del.: Scholarly Resources, 1973.

Tillson, Jr., Albert H. Gentry and Common Folk: Political Culture on a Virginia Frontier, 17401789. Lexington: University Press of Kentucky, 1991.

Trigger, Bruce G., ed. Northeast. Vol. 15, Handbook of North American Indians. Washington, D.C.: Smithsonian Institution, 1978.

. The Huron: Farmers of the North. 2d ed. Fort Worth: Harcourt Brace Jovanovich College Publishers, 1990.

Turner, Frederick Jackson. The Frontier in American History. New York: Holt, Rinehart and Winston, 1962.

Van Every, Dale. Forth to the Wilderness: The First American Frontier, 1754-1774. New York: Morrow, 1961.

Verhoeff, Mary. The Kentucky Mountains, Transportation and Commerce, 1750-1911. Filson Club Publication 26. Louisville: John P. Morton, 1911.

Wallace, Anthony F. C. Jefferson and the Indians: The Tragic Fate of the First Americans. Cambridge, Mass.: Harvard University Press, 1999.

. The Death and Rebirth of the Seneca. New York: Vintage Books, 1969.

Wallace, Paul A. W. Indian Paths of Pennsylvania. Harrisburg: Pennsylvania Historical and Museum Commission, 1965.

. Indians in Pennsylvania. Harrisburg: Pennsylvania Historical and Museum Commission, 1961. 
Weatherford, Jack. Indian Givers: How the Indians of the Americas Transformed the World. New York: Fawcett Columbine, 1988. . Native Roots: How the Indians Enriched America (New York: Ballantine Books, 1991.

Weller, Jack E. Yesterday's People: Life in Contemporary Appalachia. Lexington: University of Kentucky Press, 1965.

White, Richard. The Middle Ground: Indians, Empires, and Republics in the Great Lakes Region, 1650-1815. Cambridge: Cambridge University Press, 1991.

. The Roots of Dependency: Subsistence, Environment, and Social Change among the Choctaws, Pawnees, and Navajos. Lincoln: University of Nebraska Press, 1983.

Wiebe, Robert H. The Opening of American Society. New York: Alfred A. Knopf, 1984.

Wilcox, William J. Pricketts Fort: How and Why It Came to Be! N.p., n.d.

Wiley, Samuel T. History of Monongalia County, West Virginia. Kingwood, W. Va.: Preston Publishing Company, 1883.

Williamson, J. W., ed. An Appalachian Symposium: Essays Written in Honor of Cratis D. Williams. Boone, N.C.: Appalachian State University Press, 1977.

Williamson, J. W. Hillbillyland. Chapel Hill: University of North Carolina Press, 1995.

Willson, David Harris. A History of England. Hinsdale, Ill.: Dryden Press, 1967.

Withers, Alexander Scott. Chronicles of Border Warfare. Edited by Reuben Gold Thwaites. 1895. Reprint. Parsons, W.Va.: McClain, 1989.

Wood, Gordon. The Creation of the American Republic, 1776-1787. Chapel Hill: University of North Carolina Press, 1969.

Wright, J. E., and Doris S. Corbett. Pioneer Life in Western Pennsylvania. Pittsburgh: University of Pittsburgh Press, 1940.

Wright, Louis B. Religion and Empire: The Alliance Between Piety and Commerce in English Expansion, 1558-1625. Chapel Hill: University of North Carolina Press, 1943.

Wust, Klaus. The Saint-Adventurers of the Virginia Frontier: Southern Outposts of Ephrata. Edinburg, Va.: Shenandoah History, 1977. 


\section{$\underline{\text { Articles }}$}

Adams, Jr., Donald R. "Prices and Wages in Antebellum America: The West Virginia Experience." The Journal of Economic History 52 (March 1992): 206-16.

Allen, James Lane. "Through Cumberland Gap on Horseback.” Harper's Magazine 73 (June 1886): 50-66.

Anderson, James Donald. "Vandalia: The First West Virginia?" West Virginia History 40 (Summer 1979): 375-92.

Baker, Stanley W. "An Iron Trade Axe from the Neale's Landing Site, 46WD39, on Blennerhassett Island." West Virginia Archeologist 36 (Fall 1984): 50-53.

. "Evidence of Bison in the Aboriginal Arts and Cultural Record of the Upper Ohio Valley.” West Virginia Archeologist 50 (Spring \& Fall 1998): 26-53.

. "Neale's Landing Site Ceramics: A Perspective on the Protohistoric Period from Blennerhassett Island." West Virginia Archeologist 40 (Fall 1988): 40-53.

Batteau, Allen. "Appalachia and the Concept of Culture: A Theory of Shared Misunderstandings." Appalachian Journal 7 (Autumn-Winter, 1979-80): 9-31.

Beeman, Richard R. "Deference, Republicanism, and the Emergence of Popular Politics in Eighteenth-Century America." The William and Mary Quarterly 49 (July 1992): 401-30.

Berkley, Earl E. "Where Ancient Trails Once Crossed." Journal of the Greenbrier Historical Society 4, no. 5 (1985): 24-37.

Billings, Dwight, Kathleen Blee, and Louis Swanson. "Culture, Family, and Community in Preindustrial Appalachia." Appalachian Journal: A Regional Studies Review 13 (Winter 1986): $154-70$.

Bond, Beverly W., Jr., "The Captivity of Charles Stuart, 1755-57.” The Mississippi Valley Historical Review 13 (June 1926): 58-81.

Broshar, Helen. "The First Push Westward of the Albany Traders." The Mississippi Valley Historical Review 7 (December 1920): 327-66.

Brown, Leona Gwinn. "George Washington in West Virginia." West Virginia History 20 (October 1958): 36-44.

Carlisle, Ronald C. "Fort Gaddis and the Construction of a Revolutionary War Fort at Beech 
Bottom, West Virginia.” West Virginia History 39 (July 1978): 324-40.

Carroll, George. "Lewis Wetzel: Warfare Tactics on the Frontier." West Virginia History 50 (1991): 79-90.

Clay, Berle R. and Charles M. Niquette. "Middle Woodland Mortuary Rituals in the Gallipolis Locks and Dam Vicinity, Mason County, West Virginia." West Virginia Archeologist 44 (Spring \& Fall 1992): 1-25.

Cook, Roy Bird. "Virginia Frontier Defenses: 1719-1795.” West Virginia History 1 (January 1940): 119-130.

Dobyns, Henry F. "Disease Transfer at Contact." Annual Review of Anthropology 22 (1993): 273-291.

Eslinger, Ellen. "Migration and Kinship on the Trans-Appalachian Frontier: Strode's Station, Kentucky." Filson Club Quarterly 62 (January 1988): 52-66.

[Fallam, Robert]. "Explorations Beyond the Mountains." The William and Mary Quarterly. 15 (April 1907): 234-41.

Forbes, Jack D. "Frontiers in American History and the Role of the Frontier Historian." Ethnohistory 15 (Spring 1968): 203-35.

Fowler, Daniel B. “An Old Shawnee Town in West Virginia." West Virginia Archeologist 28 (Spring \& Fall 1979): 24-29.

Frost, William Goodell. "Out Contemporary Ancestors in the Southern Mountains." Atlantic Monthly 83 (March 1899): 311-19.

Gould, Roger V. "Patron-Client Ties, State Centralization, and the Whiskey Rebellion." American Journal of Sociology 102 (September 1996): 400-29.

Handley, Harry E. "Beginnings of the Occupation of the Greenbrier Area by the English." Journal of the Greenbrier Historical Society 1 (August 1963): 5-7.

. "The Mathews Trading Post." Journal of the Greenbrier Historical Society 1 (August 1963): 8-14.

Hann, Richard L. "Another Example of Stereotypes on the Early American Frontier: The Imperialist Historians and the American Indian." Ethnohistory 20 (Spring 1973): 143-52.

Harney, Will Wallace. “A Strange Land and a Peculiar People.” Lippincott’s Magazine 12 
(October 1873): 429-38.

Hart, John Fraser. "Land Rotation in Appalachia." Geographical Review 67 (April 1977): 148-66.

Henke, Mary L. "What Do We Know, Think we Know, and Would Like to Find Out About Capt. Jacob Prickett's Background?" The Prickett Fence (October 1993): 2-3.

Henretta, James A. "Families and Farms: Mentalité in Pre-Industrial America." The William and Mary Quarterly 35 (January 1978): 3-32.

_. "Families and Farms: Mentalité in Pre-Industrial America: Reply." The William and Mary Quarterly 37 (October 1980): 696-700.

Hood, Adrienne D. "The Material World of Cloth: Production and Use in Eighteenth-Century Rural Pennsylvania." The William and Mary Quarterly 53 (January 1996): 43-66.

Hsiung, David C. "How Isolated Was Appalachia?: Upper East Tennessee, 1780-1835." Appalachian Journal 16 (Summer 1989): 336-49.

Kellogg, Louise Phelps. "West Virginia Material in the Draper Manuscripts." West Virginia History 2 (October 1940): 5-11.

Kniffen, Fred. and Henry Glassie. "Building in Wood in the Eastern United States: A Time-Place Perspective.” Geographical Review 56 (January 1966): 40-66.

Kroeber, A. L. "Nature of the Land-Holding Group.” Ethnohistory 2 (Autumn 1955): 303-14.

Kulikoff, Allan. "Households and Markets: Toward a New Synthesis of American Agrarian History." The William and Mary Quarterly 50 (April 1993): 342-55.

. "The Transition to Capitalism in Rural America." The William and Mary Quarterly 46 (January 1989): 120-44.

Lemon, James T. "Early Americans and Their Social Environment." Journal of Historical Geography 6 (April 1980): 115-31.

Lewis, Clifford M. "The Reconnaissance Expedition of Two French Navigators." West Virginia History 43 (Fall 1981): 21-38.

. "A Frontier Store in Western Virginia.” West Virginia History 32 (July 1971): 238-44.

Lewis, Ronald L., and Dwight B. Billings. "Appalachian Culture and Economic Development: A Retrospective View on the Theory and Literature." Journal of Appalachian Studies 3 (Spring 
1997): 3-42.

Lilly, Paul R. "The Drovers.” Journal of the Greenbrier Historical Society 4, no. 6 (1986): 1318.

Lockard, E. Kidd. "Some Problems of the Draft in Revolutionary Virginia." West Virginia History 37 (April 1976): 201-10.

MacCord, Howard A. "The Susquehannock Indians in West Virginia, 1630-77." West Virginia History 13 (July 1952): 239-53.

McDonald, Forrest, and Ellen Shapiro McDonald. "The Ethnic Origins of the American People, 1790." The William and Mary Quarterly 37 (April 1980): 179-99.

McDonald, Forrest and Grady McWhiney. "The Antebellum Southern Herdsman: A Reinterpretation.” Journal of Southern History 41 (May 1975): 147-66.

McDonald III, William Naylor. "The McDonald Who Turned Washington Down." West Virginia History 38 (July 1977): 312-18.

McGinn, Robert and Larry Vaden. "Michael Cresap and the Cresap Rifles." West Virginia History 39 (July 1978): 341-47.

McMahon, Sarah F. "A Comfortable Subsistence: The Changing Composition of Diet in Rural New England, 1620-1840.” The William and Mary Quarterly 42 (January 1985): 26-65.

Manson, Carl and Howard MacCord. "An Historic Iroquois Site Near Romney, West Virginia." West Virginia History 2 (July 1941): 290-93.

Maxwell, Hu. "The Use and Abuse of Forests by the Indians." William and Mary College Quarterly Historical Magazine 19 (October 1910): 73-103.

Merrill, Michael. 'Putting 'Capitalism' in Its Place: A Review of Recent Literature." The William and Mary Quarterly 52 (April 1995): 315-26.

Moore, Jack B. "The Earliest Printed Version of David Morgan and the Two Indians." West Virginia History 23 (January 1962): 100-5.

Moore, John H. "A Captive of the Shawnees, 1779-1784." West Virginia History 23 (July 1962): 287-96.

Moxley, Ronald W. "The Orchard Site: A Proto-Historic Fort Ancient Site in Mason County, West Virginia.” West Virginia Archeologist 40 (Spring 1988): 32-41. 
Nichols, Franklin Thayer. "The Organization of Braddock's Army.” The William and Mary Quarterly 4 (April 1947): 125-47.

Nobles, Gregory H. "Breaking into the Backcountry: New Approaches to the Early American Frontier, 1750-1800." The William and Mary Quarterly 46 (October 1989): 641-70.

Nodyne, Kenneth Robert. "A Vignette of Wheeling During the Early Republic (1783-1840)." West Virginia History 40 (Fall 1978): 47-54.

Norana, Delf. "Early Postal Service in Western Virginia, 1792 to 1800." West Virginia History 2 (October 1940): 36-51.

O’Brien, Dennis., ed. “A Lost Diary of the Western Virginia Frontier.” West Virginia History 40 (Fall 1978): 55-68.

Otto, J. S., and N. E. Anderson. "Slash-and-Burn Cultivation in the Highlands South: A Problem in Comparative Agricultural History." Comparative Studies in Society and History 24 (January 1982): 131-47.

Parkinson, Robert G. "From Indian Killer to worthy Citizen: The Revolutionary Transformation of Michael Cresap.” William and Mary Quarterly 63 (January 2006): 97-122.

Perkins, Elizabeth A. "The Consumer Frontier: Household Consumption in Early Kentucky." The Journal of American History 78 (September 1991): 486-510.

Salstrom, Paul. "Appalachia's Informal Economy and the Transition to Capitalism." Journal of Appalachian Studies 2 (Fall 1996): 213-33.

. "Subsistence-Barter-and-Borrow Systems: An Approach to West Virginia's Economic History." West Virginia History 51 (1992): 45-53.

Schlesier, Karl L. "Epidemics and Indian Middlemen: Rethinking the Wars of the Iroquois, 16091653." Ethnohistory 23 (Spring 1976): 129-45.

Seed, Patricia. "Taking Possession and Reading Texts: Establishing the Authority of Overseas Empires." The William and Mary Quarterly 49 (April 1992): 183-209.

Semple, Ellen Churchill. "The Anglo-Saxons of the Kentucky Mountains: A Study in Anthropogeography.” The Geographical Journal 17 (June 1901): 588-623.

Slaughter, Thomas P. "The Tax Man Cometh: Ideological Opposition to Internal Taxes, 17601790." The William and Mary Quarterly 41 (October 1984): 566-91. 
Stealey III, John Edmund. "George Clendinen and the Great Kanawha Valley Frontier: A Case Study of the Frontier Development of Virginia.” West Virginia History 27 (July 1966): 27895.

Swiger, C. Wade. "Prickett's Fort.” The West Virginia Review (August 1935): 336-37.

Swope, Frances Alderson., comp. “The Mathews Trading Post Ledger, 1771-1779.” Journal of the Greenbrier Historical Society 4, no. 4 (1984): 20-60.

Swope, Kenneth D. "Ginseng." Journal of the Greenbrier Historical Society 4, no. 2 (1982): 107-112.

Thornton, Russell. "Aboriginal North American Population and Rates of Decline, ca. A.D. 15001900." Current Anthropology 38 (April 1997): 310-15.

Ubelaker, Douglas H. "Human Skeletal Remains from the Thorn Mounds (46MG78 and 46MG79).” West Virginia Archeologist 38 (Fall 1986): 51-53.

Vickers, Daniel. "Competency and Competition: Economic Culture in Early America." The William and Mary Quarterly 47 (January 1990): 13-29.

Voegelin, Erminie Wheeler. "The Place of Agriculture in the Subsistence Economy of the Shawnee." Papers of the Michigan Academy of Science, Arts and Letters 26 (1940): 513-20.

Walls, David S., and Dwight Billings. "The Sociology of Southern Appalachia.” Appalachian Journal 5 (Autumn 1977): 131-44.

Wilhelm, Eugene J. "Animal Drives: A Case Study in Historical Geography." The Journal of Geography 66 (September 1967): 327-34.

Wilson, Darlene. "The Felicitous Convergence of Mythmaking and Capital Accumulation: John Fox Jr. and the Formation of An(Other) Almost-White American Underclass." Journal of Appalachian Studies 1 (Fall 1995): 5-44.

Witthoft, John, and William A. Hunter. "The Seventeenth-Century Origins of the Shawnee." Ethnohistory 2 (Winter 1955): 42-57.

Young, Chester Raymond. "The Stress of War upon the Civilian Population of Virginia, 17391760.” West Virginia History 27 (July 1966): 251-277.

Dissertations and Theses 
Barnes, L. Diane. "Avenues to a Market Economy: Harrison County, West Virginia, to 1860." Master's thesis, West Virginia University, 1995.

Boback, John Marlin. "Commercialism, Subsistence, and Competency on the Western Virginia Frontier, 1765-1800.” Master's thesis, West Virginia University, 2000.

Workman, Michael E. "Political Culture and the Coal Economy in the Upper Monongahela Region: 1776-1933.” Ph.D. diss., West Virginia University, 1995.

$\underline{\text { Internet }}$

Maslowski, Robert F. "Prehistoric People of the Kanawha Valley."

<http://www.wvlc.wvnet.edu/wvarl/srbk.html>, 13 September 1997.

Wilson, Sonja L. "Mountaineer Week History"

$<$ http://www.sa.wvu.edu/mountainlair/history.shtml $>13$ January 2005. 


\section{Appendix A}

Chronology of the western Virginia Frontier

1660s Iroquois attacks into Ohio Valley

1671 Thomas Batts and Arthur Fallam expedition

$1674 \quad$ Gabriel Arthur captured by Shawnees

1680s (circa) Shawnee nation disperses widely

1720s-1730s Many Shawnees return to Ohio Valley

1749 European settlement of trans-Allegheny Virginia begins with Stephen Sewel and Jacob Marlin

1753 Scattered Indian attacks in western Virginia

$1754 \quad$ French and Indian War begins

1750s (mid) All settlements in trans-Allegheny Virginia abandoned/destroyed

1758 Fall of Fort Duquesne - French and Indian War ends in Ohio Valley

1759 Settlers begin returning to frontier

$1763 \quad$ Pontiac's Uprising begins

$1763 \quad$ Proclamation of 1763 closes frontier to settlement

1764 (circa) All settlements in trans-Allegheny Virginia abandoned/destroyed for second time

$1765 \quad$ Pontiac's Uprising ends

1766 Settlers again return to frontier

1768 Treaties of Fort Stanwix and Hard Labor adjust Proclamation Line westward 
toward Ohio River

1773 Indians becoming increasingly angry over white settlements in Ohio Valley

1774 (APR) Massacre of Chief Logan's family - Dunmore's War

1774 (OCT) Battle of Point Pleasant ends Dunmore's War

$1775 \quad$ Revolutionary War begins

1776 Mingoes and many Shawnees side with British

1777 "Bloody Year of the Sevens" on frontier

1779 (circa) 1,200 Shawnees abandon upper Ohio Valley

$1781 \quad$ Defeat of British at Yorktown

1780s Indian raiding on frontier continues

1794 Defeat of Indians at Battle of Fallen Timbers - Indian raiding in western Virginia ends 
Appendix B

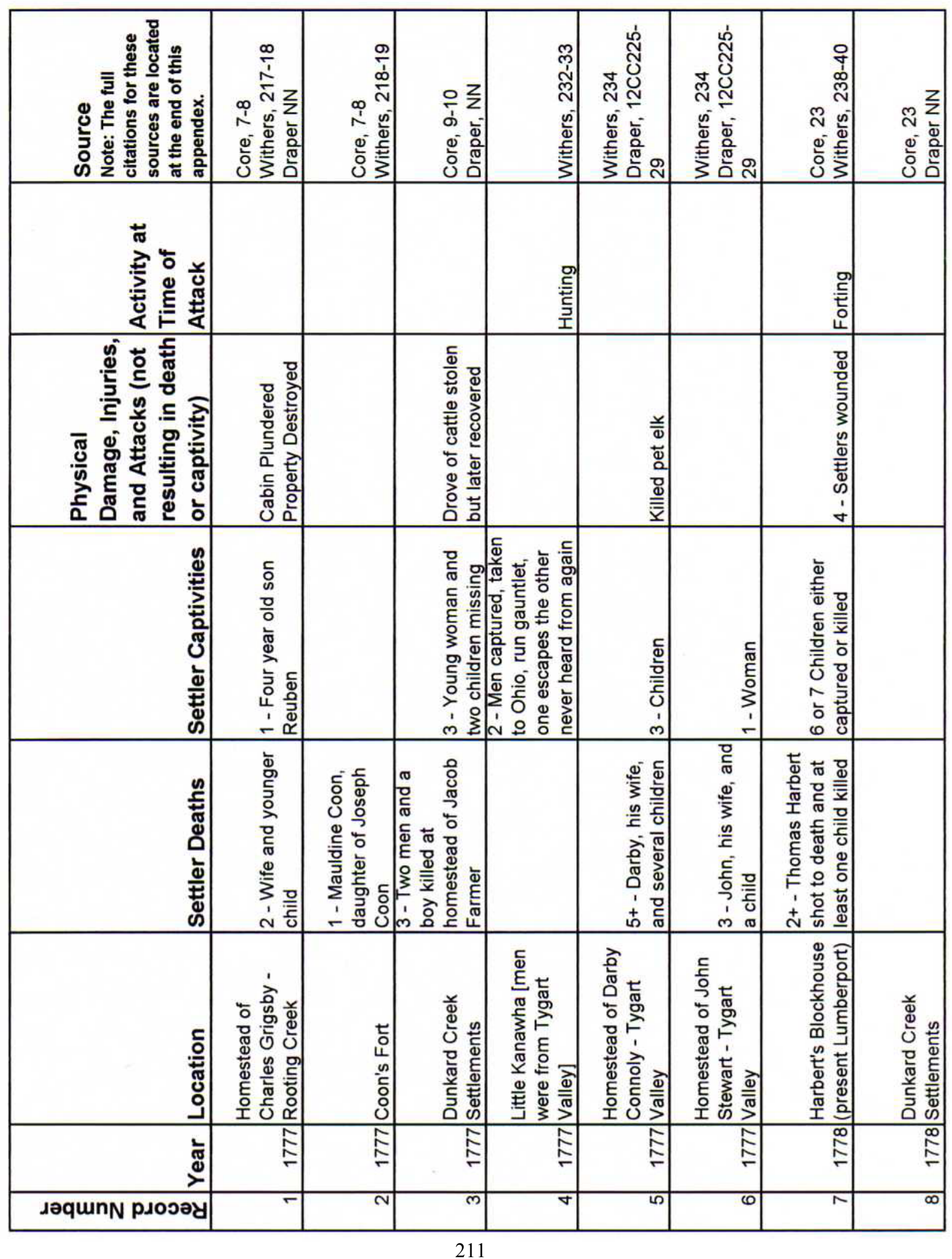




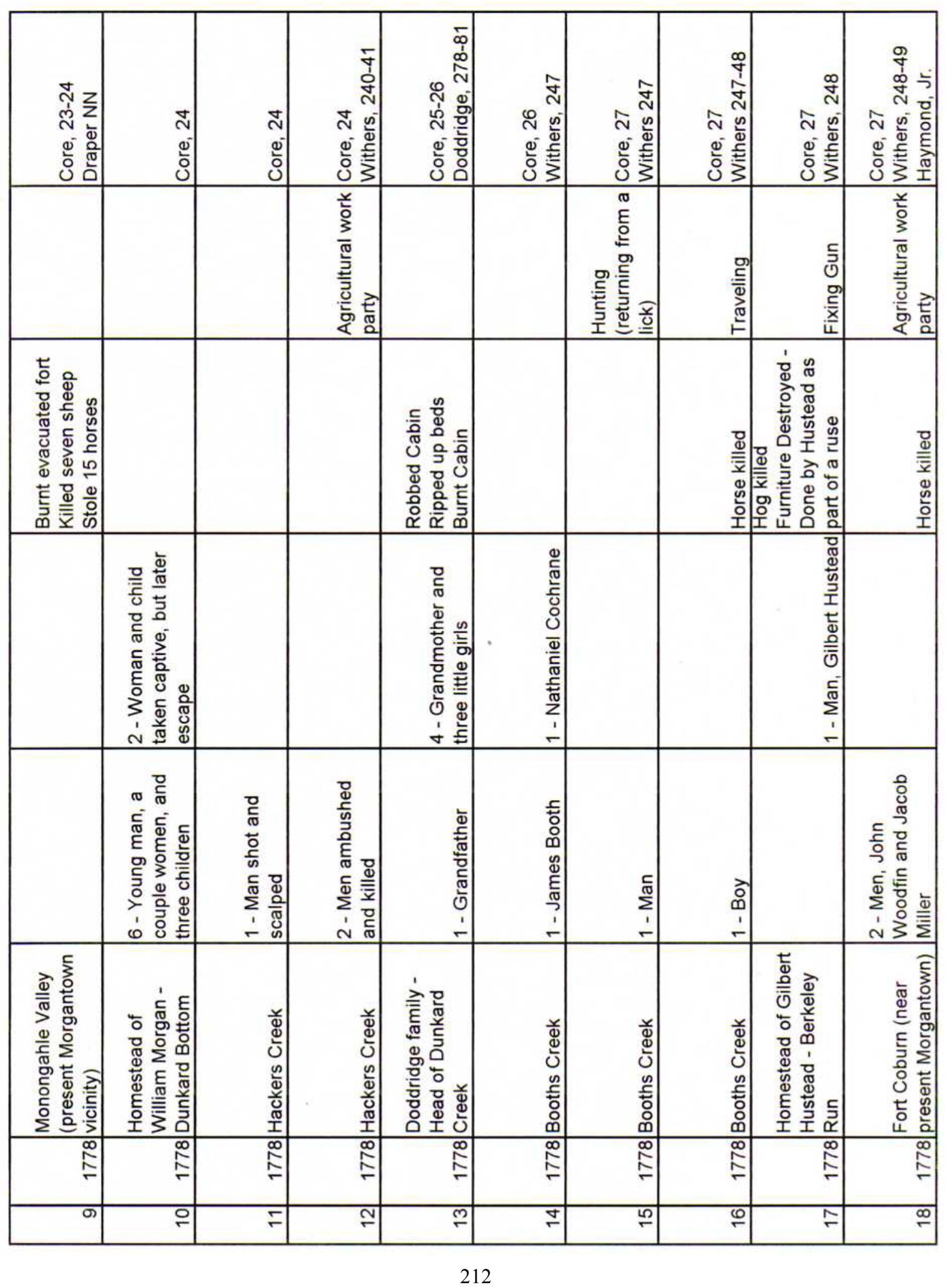




\begin{tabular}{|c|c|c|c|c|c|c|c|c|c|}
\hline 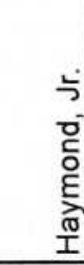 & 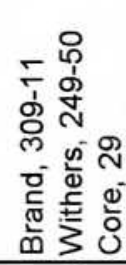 & 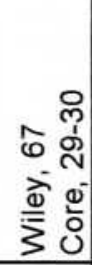 & 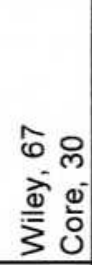 & 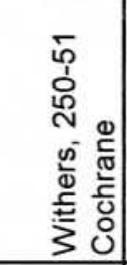 & 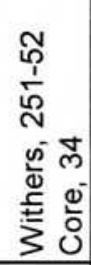 & 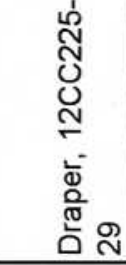 & 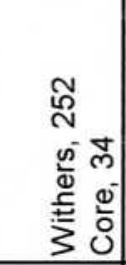 & 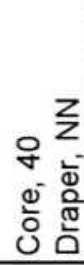 & 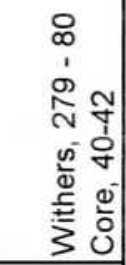 \\
\hline & 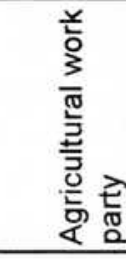 & & 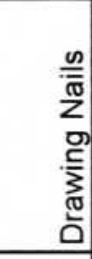 & 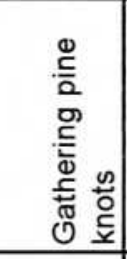 & 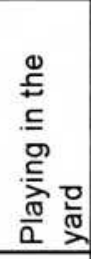 & 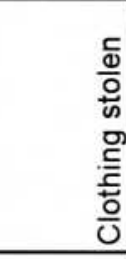 & 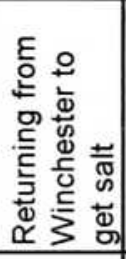 & & 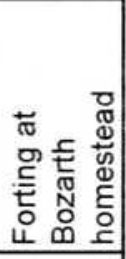 \\
\hline 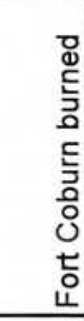 & & & & & 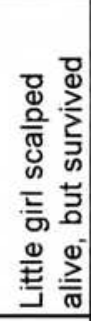 & & & 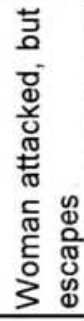 & \\
\hline & & & & 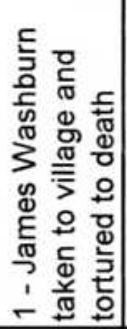 & & & & & \\
\hline & 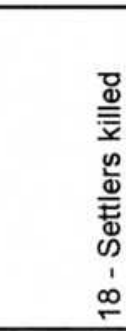 & 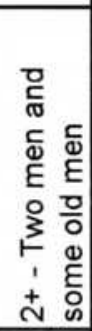 & 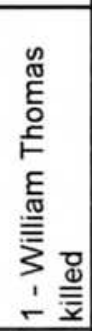 & 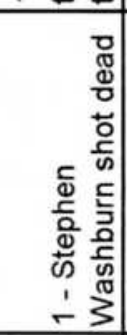 & & 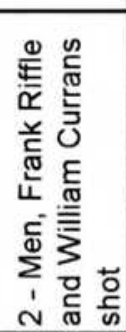 & 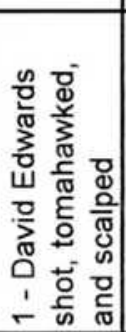 & & 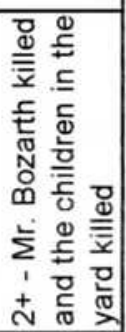 \\
\hline 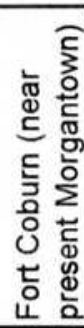 & 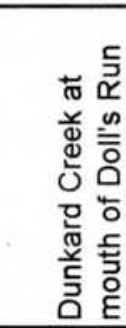 & 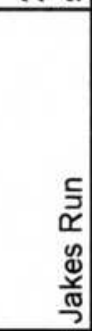 & 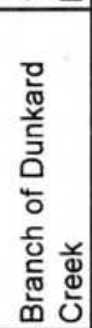 & 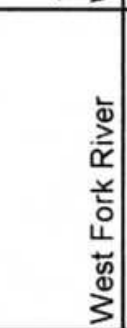 & 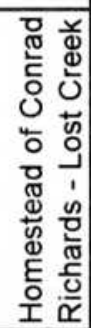 & 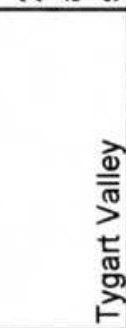 & 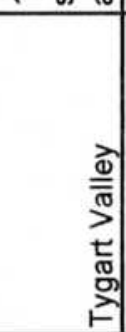 & 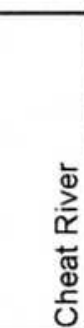 & 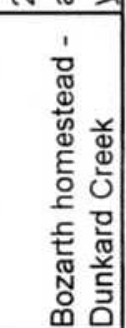 \\
\hline$\stackrel{\infty}{\stackrel{\infty}{f}}$ & $\stackrel{\infty}{\stackrel{\infty}{\digamma}}$ & 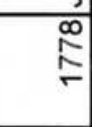 & $\stackrel{\infty}{\stackrel{\infty}{f}}$ & 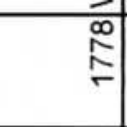 & $\stackrel{\infty}{\stackrel{\infty}{f}}$ & $\begin{array}{l}0 \\
\infty \\
\stackrel{1}{上} \\
上\end{array}$ & $\begin{array}{l}0 \\
\stackrel{\infty}{N} \\
\stackrel{1}{\sim}\end{array}$ & 帝 & م \\
\hline 임 & 요 & $\bar{N}$ & $\mathbb{N}$ & ल্ & ন & $\stackrel{w}{N}$ & $\stackrel{\mathrm{N}}{ }$ & $\bar{N}$ & $\stackrel{\infty}{\sim}$ \\
\hline
\end{tabular}




\begin{tabular}{|c|c|c|c|c|c|c|c|c|c|}
\hline 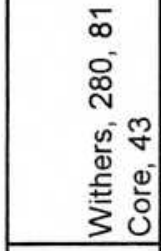 & 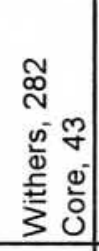 & 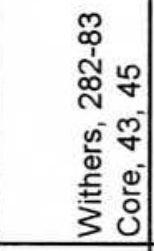 & 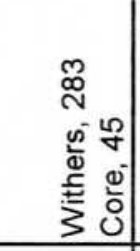 & 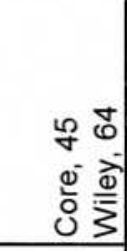 & 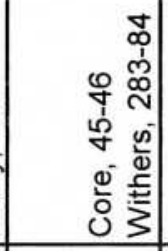 & 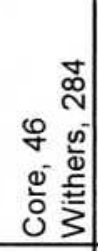 & 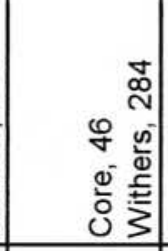 & 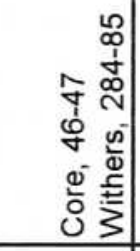 & 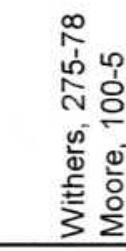 \\
\hline \multirow[t]{2}{*}{ 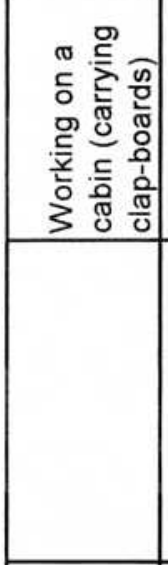 } & & 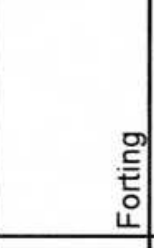 & 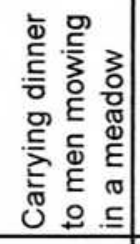 & 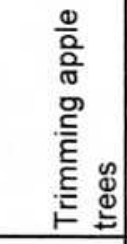 & 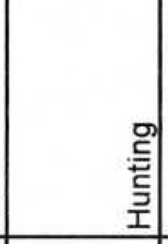 & 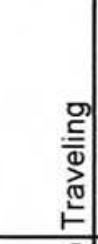 & & 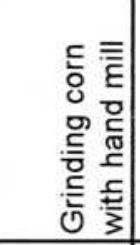 & \\
\hline & & & & 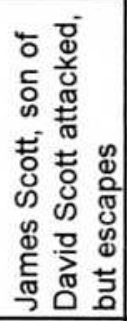 & & 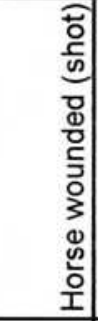 & & 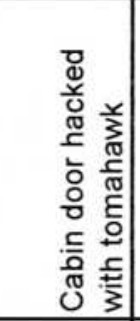 & 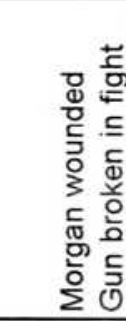 \\
\hline 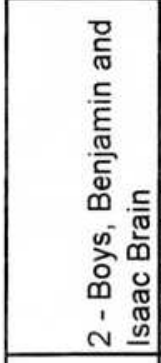 & 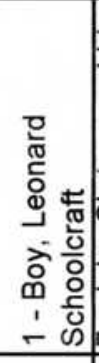 & 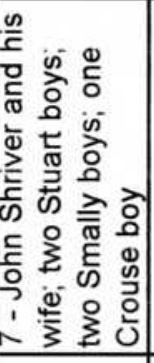 & & & & & 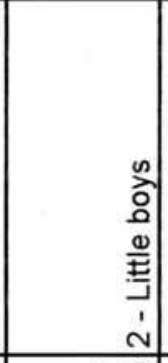 & & \\
\hline 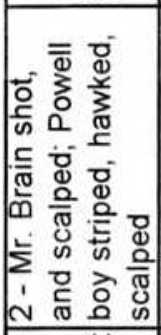 & & 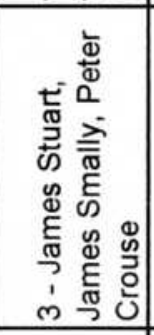 & 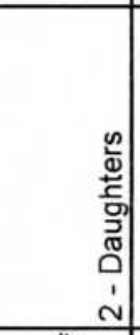 & & 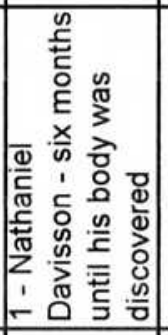 & 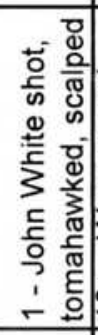 & 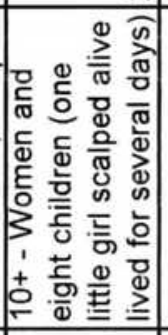 & 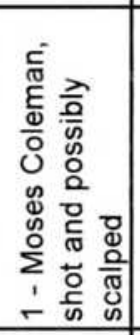 & \\
\hline 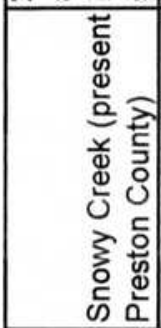 & 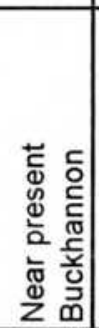 & 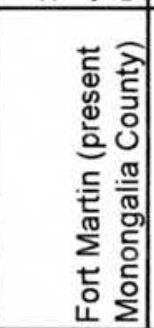 & 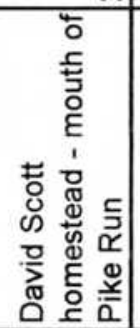 & 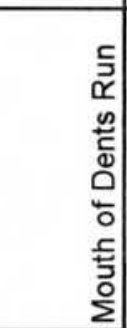 & 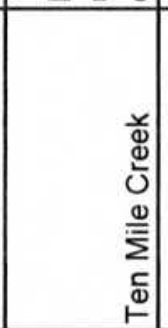 & . & 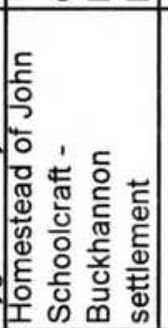 & 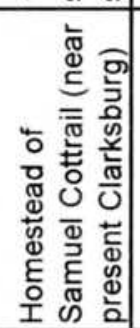 & 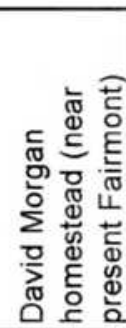 \\
\hline $\begin{array}{l}\text { क् } \\
\text { f }\end{array}$ & क्ञ & 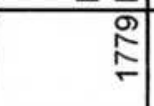 & के & 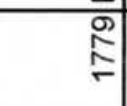 & $\begin{array}{l}\text { o } \\
\text { N } \\
-1\end{array}$ & $\begin{array}{l}\text { o } \\
\stackrel{1}{r}\end{array}$ & $\begin{array}{l}\text { श } \\
\stackrel{1}{f}\end{array}$ & 胥 & م \\
\hline त) & ০্লি & $\overline{\mathrm{m}}$ & ल্ল & ल्ల & मे & फ్ల & প্লা & ले & ळ్ల \\
\hline
\end{tabular}




\begin{tabular}{|c|c|c|c|c|c|c|c|c|}
\hline 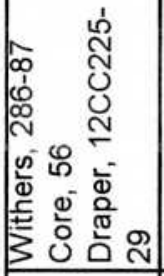 & 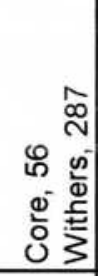 & 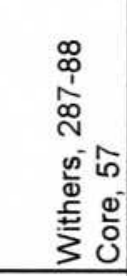 & 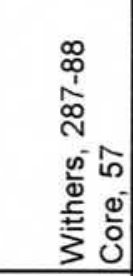 & 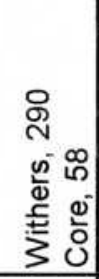 & 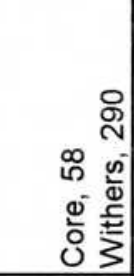 & 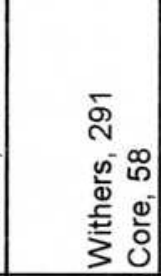 & $\begin{array}{l}0 \% \\
0 \\
0 \\
0\end{array}$ & 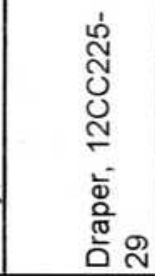 \\
\hline 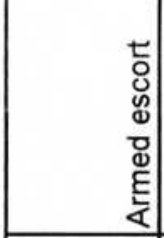 & 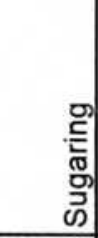 & & & & 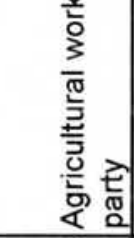 & & & \\
\hline 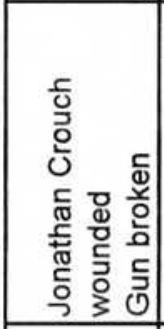 & & 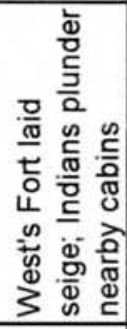 & 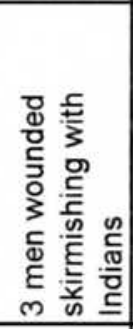 & & & & & 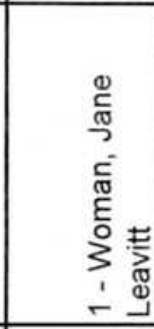 \\
\hline & 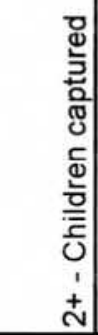 & & & 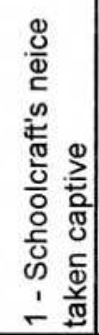 & & & & \\
\hline 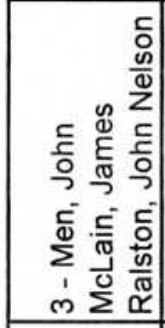 & 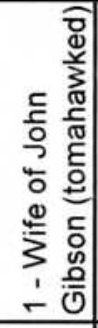 & & & 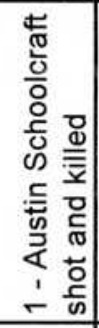 & 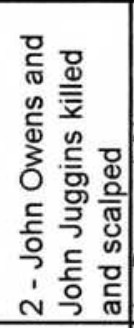 & 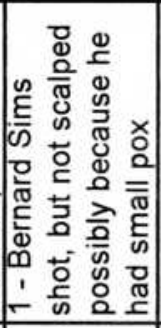 & 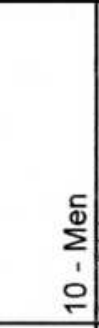 & 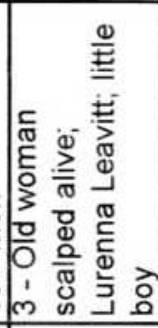 \\
\hline 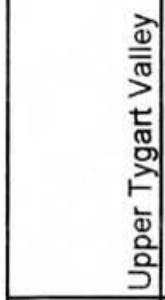 & 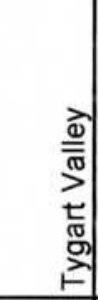 & 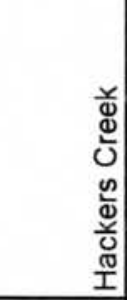 & 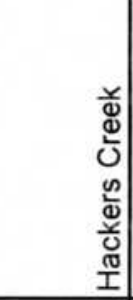 & 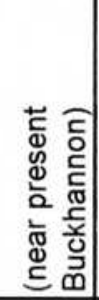 & 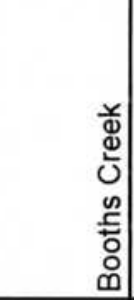 & 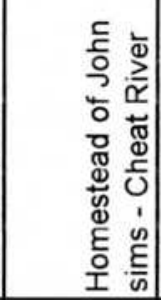 & 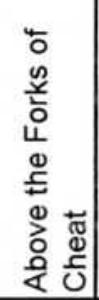 & 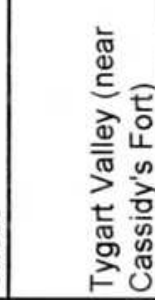 \\
\hline 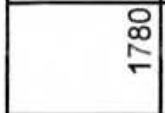 & $\begin{array}{l}0 \\
\stackrel{\infty}{*}\end{array}$ & 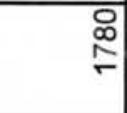 & $\begin{array}{l}0 \\
\stackrel{0}{0} \\
\stackrel{5}{\leftarrow}\end{array}$ & 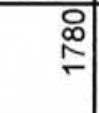 & 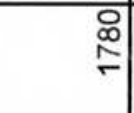 & 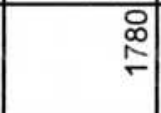 & $\begin{array}{l}0 \\
\stackrel{0}{-} \\
\stackrel{5}{-}\end{array}$ & $\begin{array}{l}0 \\
\stackrel{0}{0} \\
\stackrel{2}{\sigma}\end{array}$ \\
\hline প్ల & 아 & $\bar{\nabla}$ & $\mathcal{Y}$ & M & 8 & ช & Q & F \\
\hline
\end{tabular}


Abbreviations used in Appendix B:

Brand Brand, Franklin Marion. The Wade Family in Monongalia County, Virginia. Morgantown, W. Va.: N.p., 1927.

Cochrane Cochrane, Nathaniel. Papers. Pricketts Fort Memorial Foundation Archives, Fairmont, West Virginia.

Core $\quad$ Core, Earl L. The Monongalia Story: A Bicentennial History. Vol. 2. The Pioneers. Parsons, W.Va.: McClain, 1974.

Doddridge Doddridge, Joseph. Notes on the Settlement and Indian Wars. 1912. Reprint. Parsons, W. Va.: McClain, 1989.

Draper Draper Manuscripts. Microfilm. West Virginia and Regional History Collection, West Virginia University, Morgantown, West Virginia.

Haymond Haymond Family Papers. West Virginia and Regional History Collection, West Virginia University, Morgantown, West Virginia.

Moore $\quad$ Moore, Jack B. "The Earliest Printed Version of David Morgan and the Two Indians." West Virginia History 23 (October 1962): 100-5.

Wiley Wiley, Samuel T. History of Monongalia County, West Virginia. Kingwood, W. Va.: Preston Publishing Company, 1883.

Withers Withers, Alexander Scott. Chronicles of Border Warfare. Edited by Reuben Gold Thwaites. 1895. Reprint. Parsons, W.Va.: McClain, 1989. 


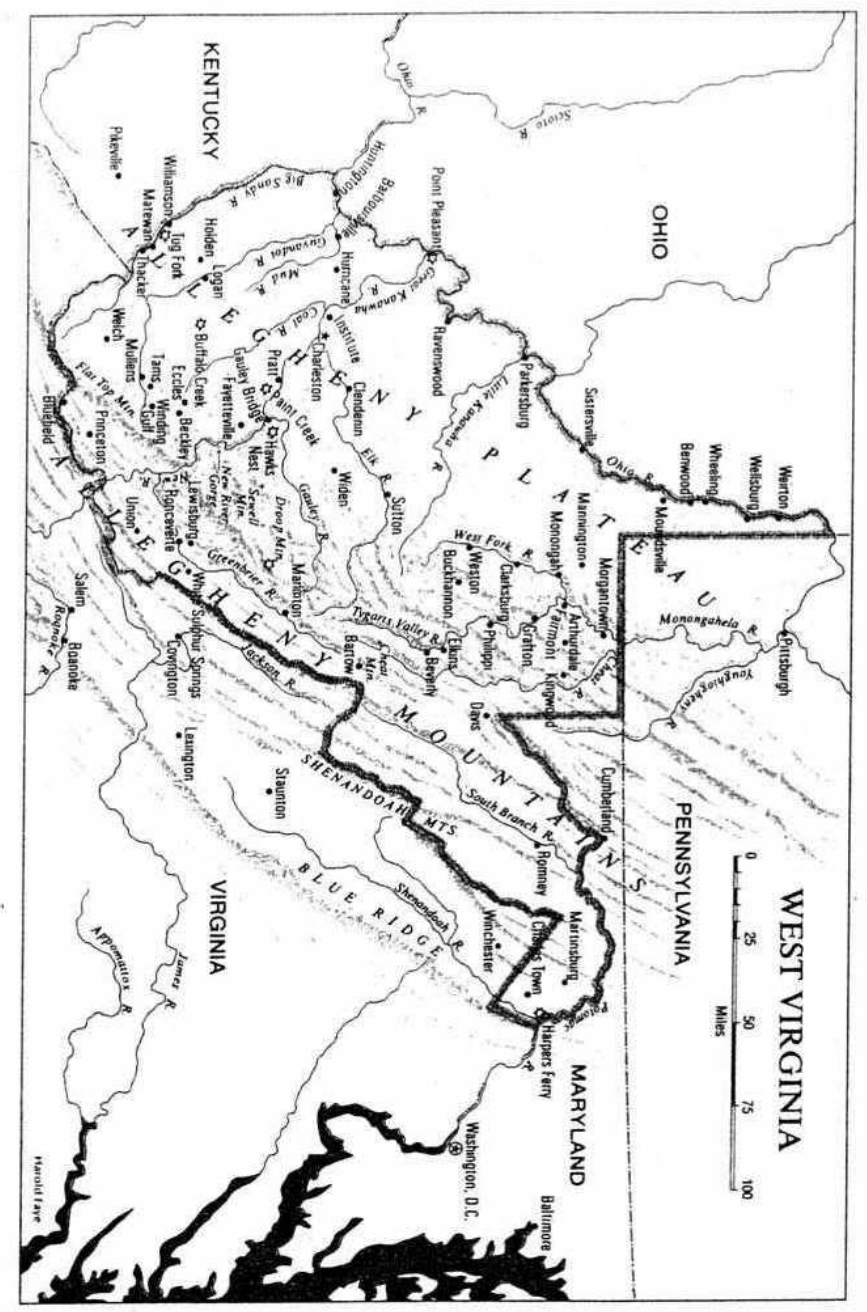

Source: Williams, John Alexander. West Virginia: A Bicentennial History. New York: W. W. Norton, 1976. 


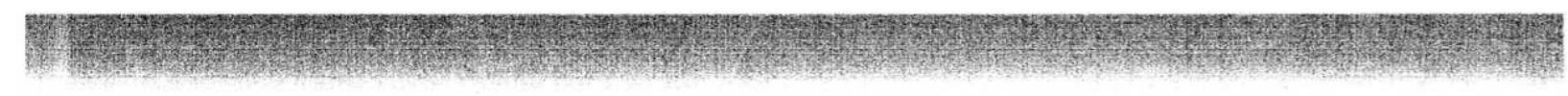

Map 2

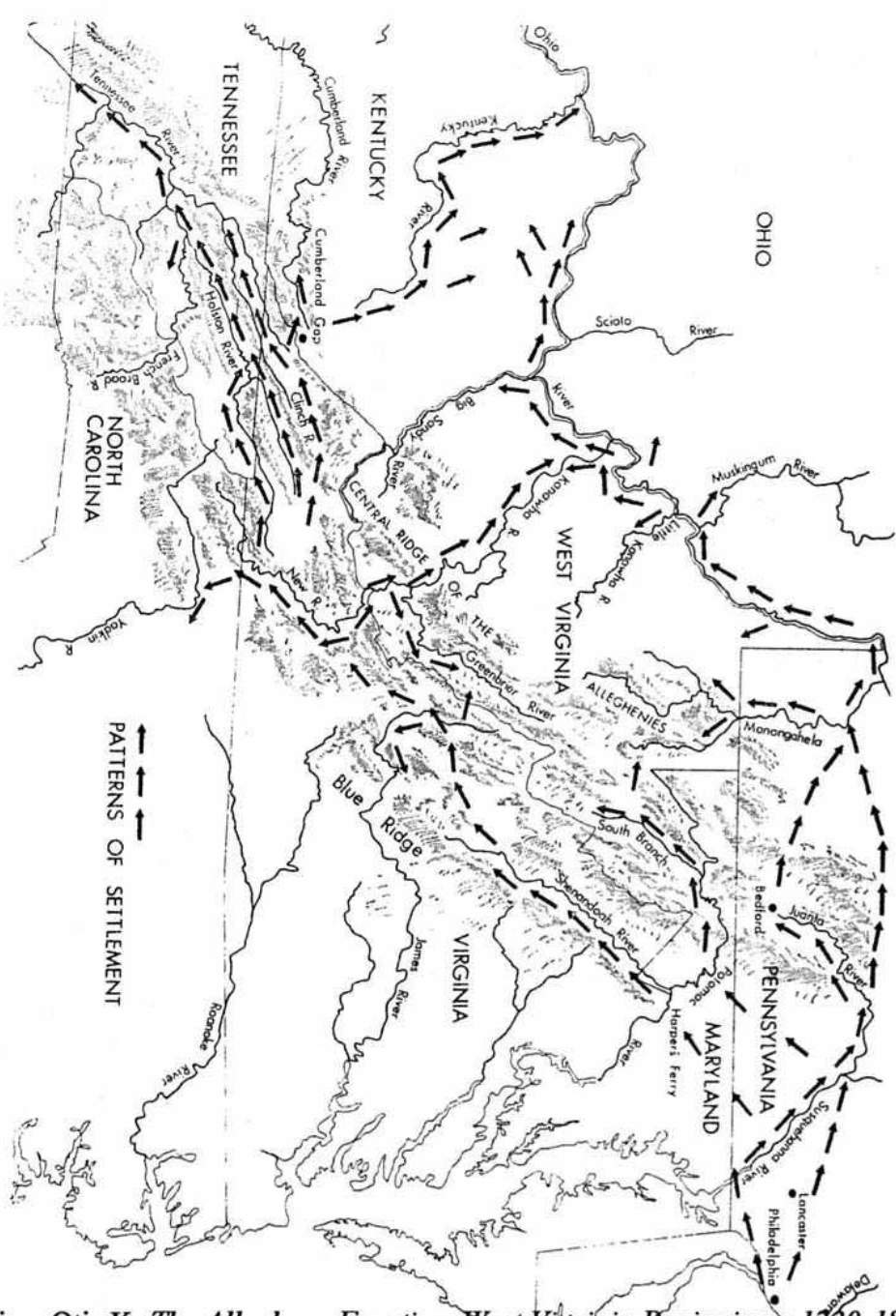

Source: Rice, Otis K. The Allegheny Frontier: West Vifginia Beginnings, $1+30-1830$.

Lexington: University Press of Kentucky, 1970. 


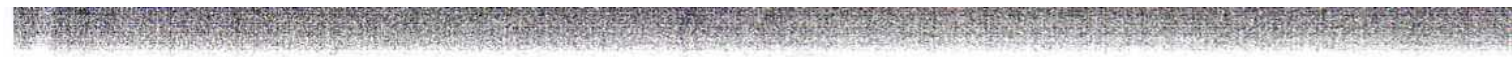

Map 3

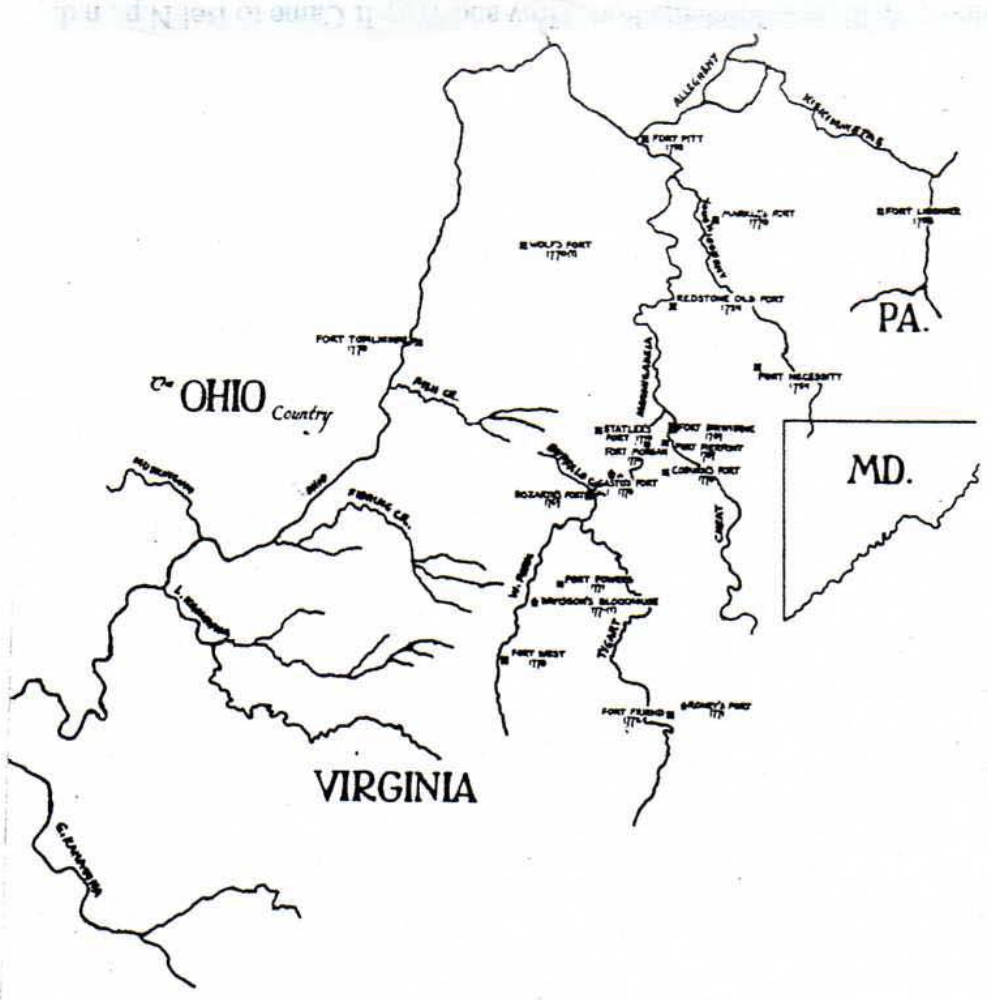

FORTS BUILT 1754-1772

Since the exact nature of all forts is not recorded in history, those of an unknown nature are marked with an "X" while those known to have been blockhouses are marked with an arrow-like figure. When exact date of building is questionable, the date is suffixed with a "?". Note that almost all forts of this period were on the Monongahela River or its tributaries.

Source: Wilcox, William J. Pricketts Fort: How and Why It Came to Be! N.p., n.d.

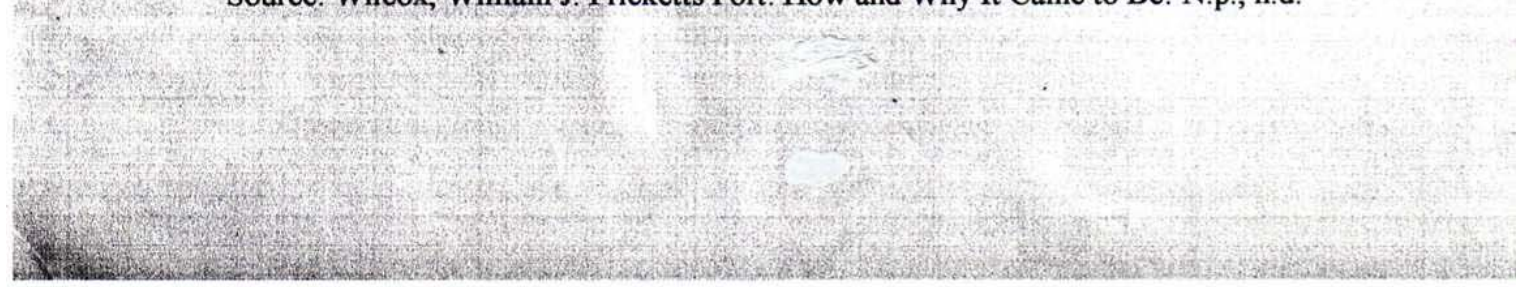




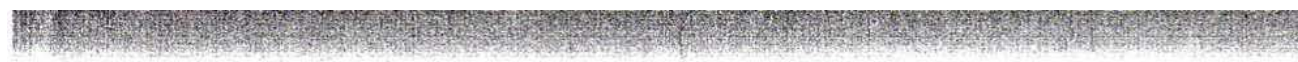

$$
\text { Man } 4
$$

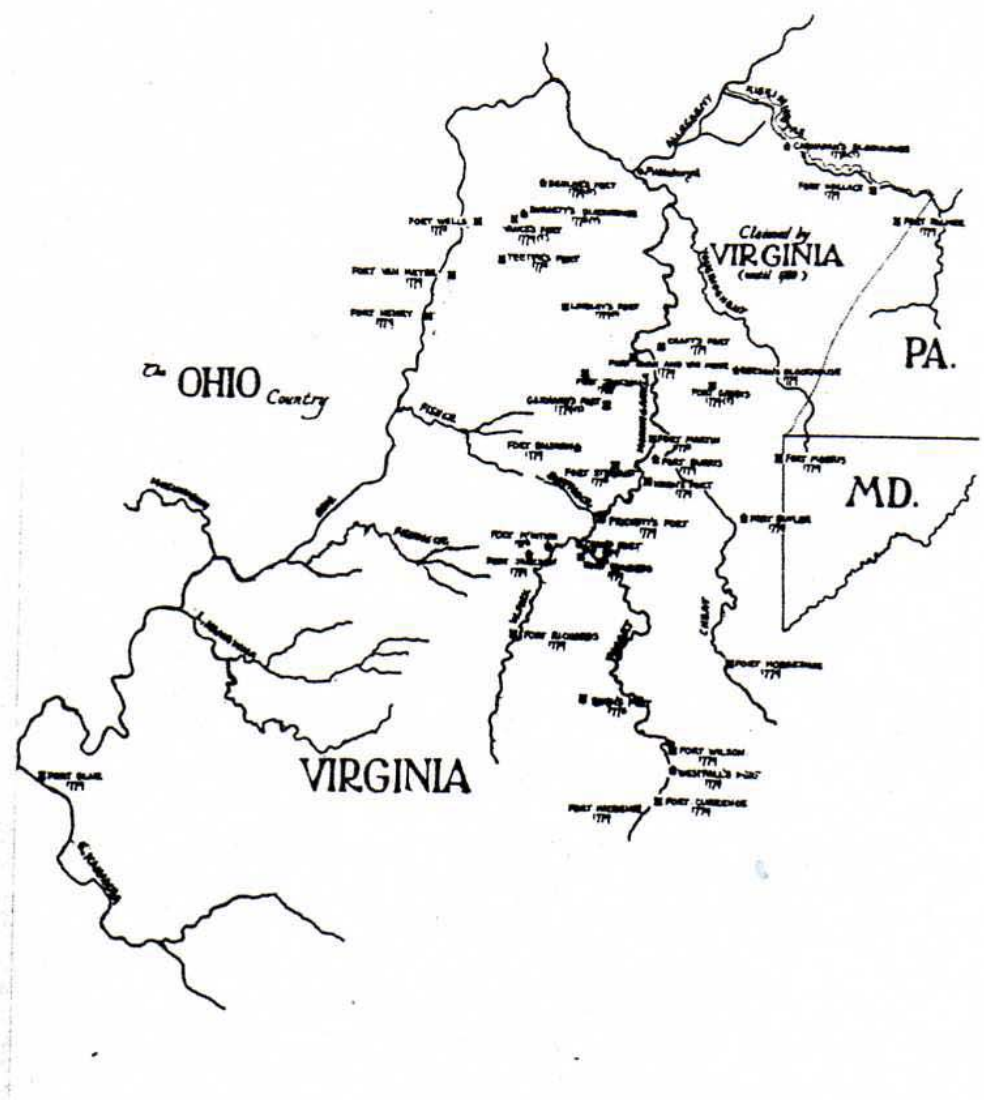

FORTS BUILT 1773-1774

Note the additional forts built along the Monongahela and its tributaries, but also note the number built along the Ohio Rivar and its tributaries leading toward the Monongahela Valley.

Source: Wilcox, William J. Pricketts Fort: How and Why It Came to Be! N.p., n.d. 


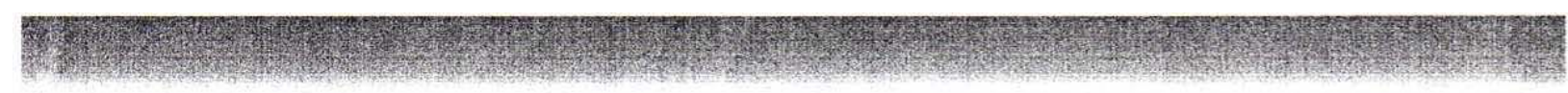

Map 5

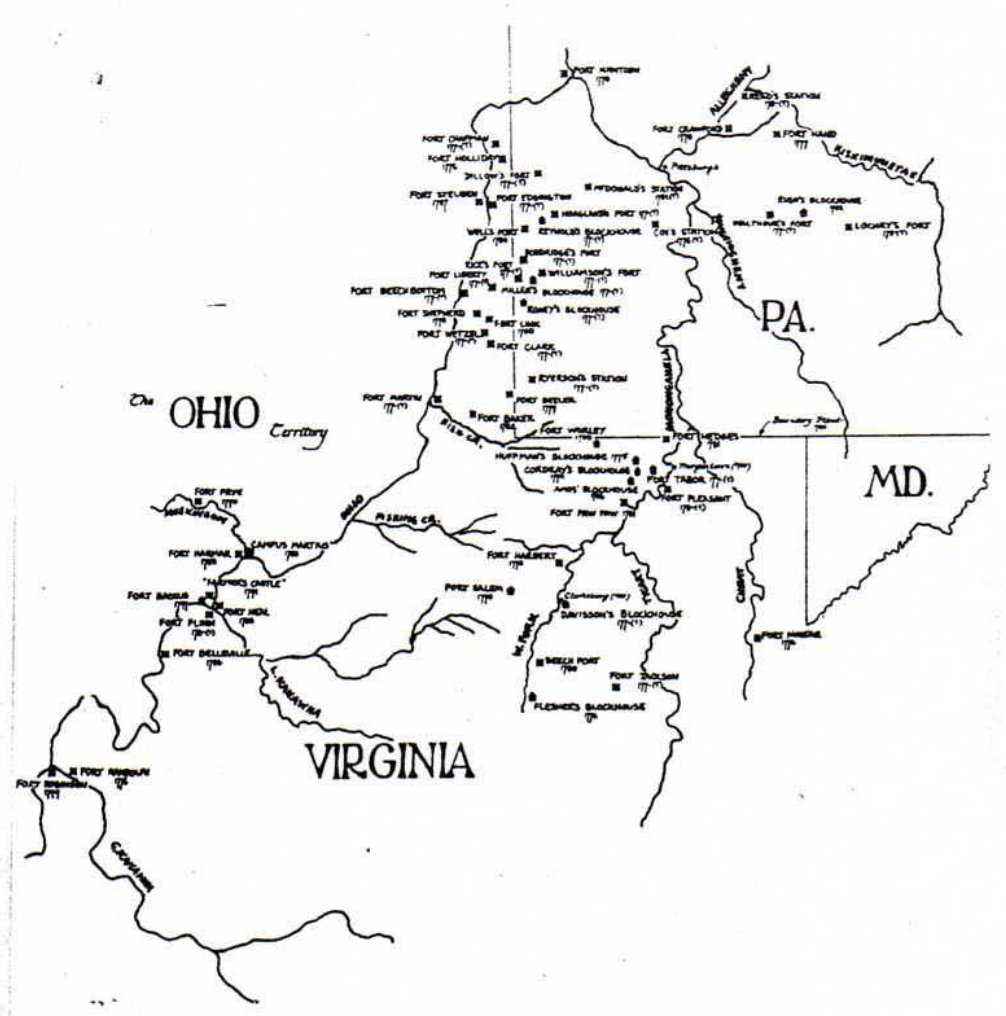

FORTS BUILT 1775-1794

Note the concentration of additional forts built along the tributaries leading toward the Monongahela Valley. The last known fort to be built in the Monongahela Valley was Ft. Saiem (a blockhouse) built as present Salem, W. Va. The last known fort to be built in the state was Ft. Robinson at the mouth of the Great Kanawha River at Pt. Pleasant, W. Va.

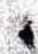

Source: Wilcox, William J. Pricketts Fort: How and Why It Came to Be! N.p., n.d. 